Historic, Archive Document

Do not assume content reflects current scientific knowledge, policies, or practices. 
1 
-

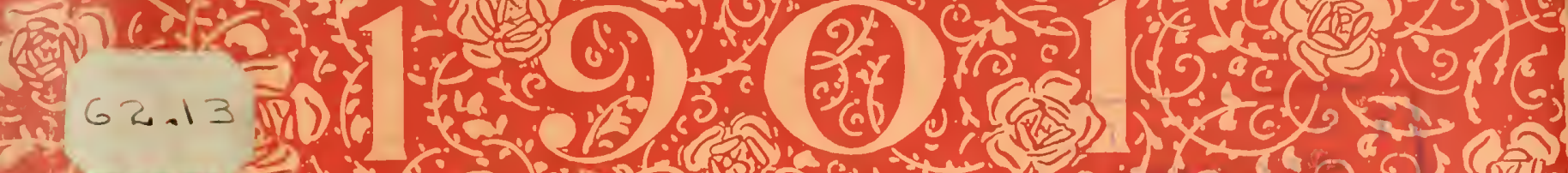
2yor CATALOGUE

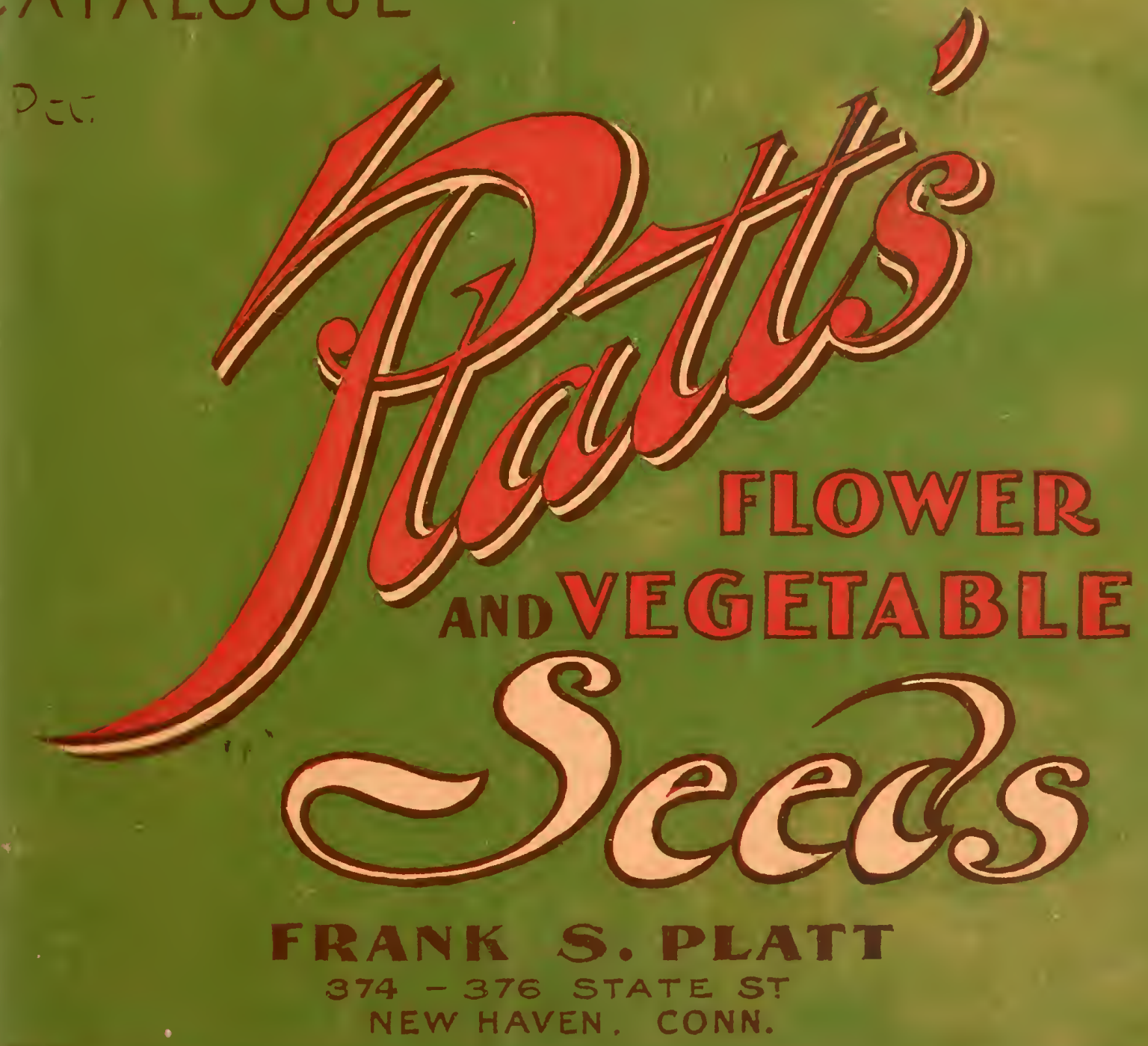

PI: $y=2008$

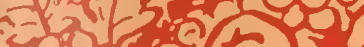
20353

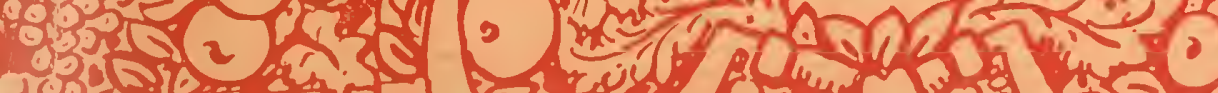
TSP

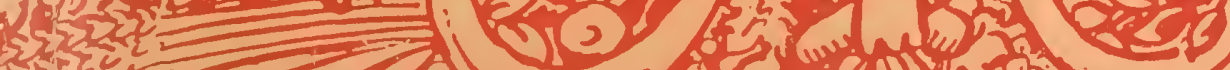

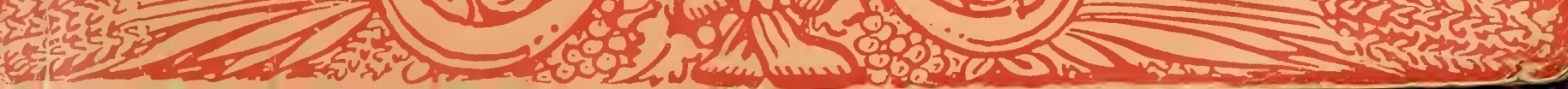

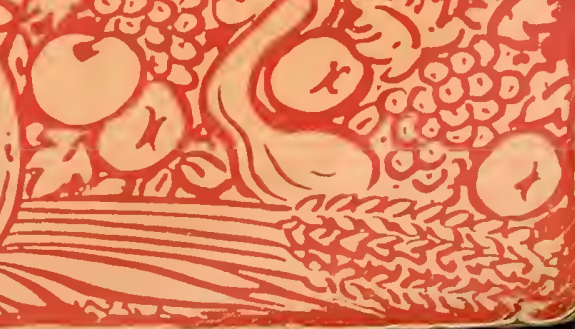




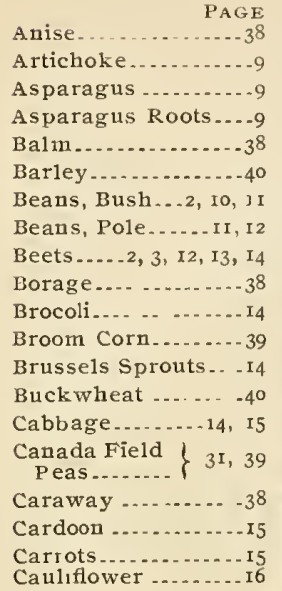

PAGE

Abronia .......... 4

Acroclinium - .......45

Adonis ..............44

Ageratum..........44

A!yssum, Sweet ...-45

dmaranthus .........45

Antirrhinum ........45

Aquilegia ..........-45

Asperula . ...........46

Aster.................46

Ba1loon Vine.....-.-47

Balsam . .............47

Balsam Apple. 47,60

Bartonia ............47

Bellis Perennis.....47

Branchycome...... -47

Browallia ..........-47

Cacalia ........ . . . - 47

Calandrinia ......... $4^{8}$

Calceolaria ........-48

Calendula ......48, 59

Calliopsis............ 48

Campanula. ........ 48

Canary Bird Flower 48

Candytuft. ........49

Bulbs.

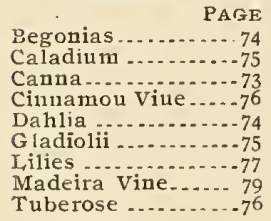

Plants, Shrubs, Trees.

Althea -......... 80 Ampelopsisveitchii 79 A pple - . . . . . . . . -8I Aristolochia ........79 Bignonia .......... . . .79 Blackberries ...... 84 California Privets. 80 Cherries

\begin{tabular}{|c|c|}
\hline Celeriac $\quad \begin{aligned} \text { PAGE } \\
\text { C.... }\end{aligned}$ & Findive . $\ldots . . .1 \%$ \\
\hline Celery ... $-4,16,17,39$ & Fenuel.......4, 22, $3^{\gamma}$ \\
\hline Chervil & Flax \\
\hline Chicory ......... 16 & Garlic Sets _.......23 \\
\hline Chives _....... & Gourds . . . . . $5^{6}$ \\
\hline Chufas ............. & Grains . . . . . . 40 \\
\hline lover seeds . . . . ...4.3.3 & Grass Seeds. $-4 I, 42,43$ \\
\hline Collards............ 18 & Hemp....... $-39,87$ \\
\hline Coriander _....... 38 & Herbs ................ 38 \\
\hline Coru, Field....... 8 & Horehound ... . \\
\hline Corn, Poppiug . . I 8 & Kaffir Coru.... \\
\hline Corn, sweet. $3,4,19,20$ & Kale......... \\
\hline Corn Salad ......20 & Kohl-Rabi....... \\
\hline Cow Peas ....... 39 & Lawn Grass Seed_. _ 4 I \\
\hline Cress or Pepper- & Lavender ............ \\
\hline grass................ 20 & Leek \\
\hline Cress, Water..... & Lettuce ....... 24, 25 \\
\hline Cucumber.....-4 21 & Mangel Wurtzel3,I3,I4 \\
\hline Dandelion $\ldots . . . .22$ & Martynia ..........26 \\
\hline Eill Eg Plant. & $\begin{array}{l}\text { Melon, Musk... } \\
\text { Melon, Water -3 }\end{array}$ \\
\hline
\end{tabular}

saffron

sage. -

Salsify -

Soja Beaı

spinach $-7,34,35,36$ Sugar Cane.......-39 summer Savory .... $3^{8}$ Sunflower .......39, 87 Sweet Basil . .......-38 Sweet Marjoram _...38 Thyme........... . . 1'obacco . . . . . . . . . - 36 'loll1ato . . . . . 8, 36, 37 Turnip.... ... $8,37,3^{8}$ Vegetable Plauts...81 Vegetable seeds. $-9,3^{8}$ Vetches, Spring - ..-39 Wheat. ...... . . . . . 40 Wormwood....... 38

\section{FLOWER SEEDS.}

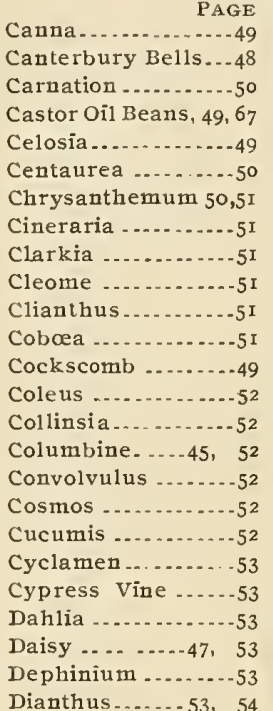

PAGE

Digitalis ...........-54

Eschscholtzia -...-54

Euphorbia......54, 55

Everlastiugs..-45, 55 , ..........56, 57,67

Feverfew -.......--55

Flower Seeds - 44 to 72

Forget-me-not.-55, 6r

Gaillardia ......... 55

Gerauium..........-55

Gilia -..........-55

Globe Amaranth .. - -55

Gnaphaliuin ........56

Godetia ............ 56

Gourds............ - 56

Grasses ............56

Helianthus.........-57

Helichrysum ......-57

Heliotrope........57

Ho'lyhock ....-57, 58

Honesty -... ....... - -58

Hyacinth Bean ..... - 56

Ice Plant............ 58

Impatiens Sultani. $-5^{8}$

Ipomea .......58, 59
PAGE

Lathyrus . . . . . . . . 59

Linum ............59

Lobelia - . . . . . . . 59

Lupins .... . . . . . . . . 60

Marigold _....... 59

Maurandia.........60

Marvel of Peru.....6r

Mignonette ........60

Mimosa . . . . . 60

Mimulus ............6o

Momordica _...47, 60

Morning Glory-52, 60

Myosotis ......55, 6I

Myrsiphyllum..6r, 68

Nasturtium ....6I, 62

Nemophila ........62

Nicotiana ..........62

Nige 1la ............62

Pansy ...............63

Petunia . . . . . . 64

Phlox .........64. 65

Physalis Francheti.65

Polyanthus.......65

Poppy.........65, 66

\section{MISGELLANEOUS.}

Cherries _.......8I $\quad \begin{aligned} & \text { Peony } \\ & \text { Peony, Mouton........... }\end{aligned}$

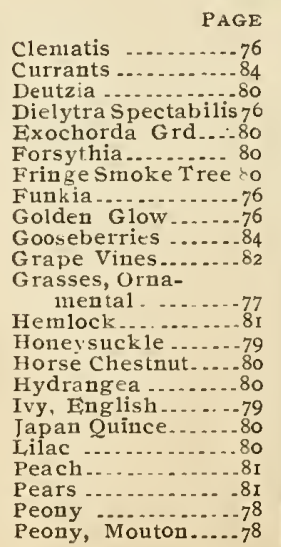

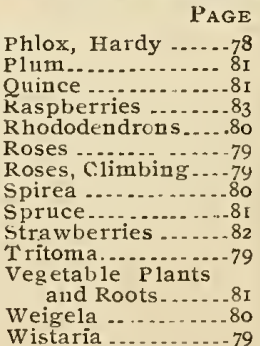

Tools and Supplies.

Bag Holder . . . . . . -92 Bean Poles. . . . . . 95 Bird Seeds ........... 87 Bird Supplies......87
Cages ........88, 80 Caponizing Tools...88 Chairs ..............-96 Corn Planter........-93 Dog Food.

Egg Food

Fertilizers

Fir Tree Oil ........85

Hlower Stands......95

Flower Pots ........93

Fountain Pumps . . . $\delta 9$

Glazier's Poiuts.....-92

Glazine Tools...... gr

Grafting Wax........

Grafting Wax.......

Hot Bed Mats......92

Insect Extermina-

tors ... ... $84,85,86$

Labels, painted....9.5

Lawn iressing.....86

Law11 Mowers......-93

Marking Punch .... 8

Mole 'Traps........96
Portulaca PAGE

Prinula ........... . 67

Pyrethrum..........66

Rhodanthe .. ..... -67

Ricinus.........49, 67 Rudbeckia..........68 Salpiglossis .......68 Salvia...............68 Sanvitalia..........68 Scabiosa ...........68 68 Schizanthus ........68 Smilax ..... 6r, 68 Solanun _.........69 Stocks . ..........69 Sweet Peas.....70, 7 I Sweet William......69 Thun bergia ........ -70 T-opcolum.... . 6r, 62 Verbena ..........7r Vinca ................7I Wall Flower.......72 Wild Flower Gar-

den .............-72 Zinnia 72 


\section{FRANK S. PlatT'S T Trenty-Fifth Annual}

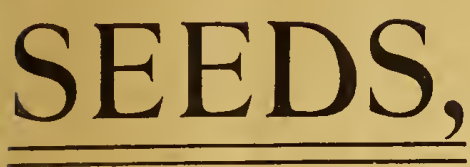

\section{Plants, Bulbs, Implements, Insecticides, Fertilizers, Poultry Supplies, Etc.}

This catalogue will undoubtedly reach some of my patrons who received the original four-page price list twenty-five years ago. A quarter of a century signifies a big block of one's business experience, but it has passed, and with it the majority of those early patrons. I am impressed with the events that have been crowded into those busy, hard-working years, and gratefully acknowledge the confidence and good will of my friends, who have enabled me to develop a large business in seeds and farm supplies.

At the opening of this silver anniversary year and the beginning of a new century, an opportunity is afforded to compare tne methods of producing and handling seeds with those of nearly half a century ago, when as a boy I had my first experience in seed growing. There were few regular seed growers who depended exclusively upon that industry for their income, and less seed stores devoted entirely to the details of the seed trade. It was the custom then for the wide awake and enterprising farmer, or gardener, to set his roots or sow the seeds of his specialties every second or third year, and sell or exchange the surplus product above his own requirements among his neighbors and friends for their favorite productions, that he might require.

The growing of seeds has become a vast industry, and can no longer be handled in an indifferent and careless manner with any chance of success. The most intelligent, painstaking efforts alone insure satisfactory results, and it has been my aim to secure the services of those whose years of experience entitle them to be classed as expert seed growers to handle my contracts. By this careful discrimination I have been enabled to offer only the best of everything in the line of field, garden and flower seeds that can.possibly be produced.

FRANK S. PLATT.

\section{TERMS AND DIRECTIONS FOR ORDERING.}

Termis. Cash with order, or satisfactory city reference. I will ship by express, ${ }^{\circ}$. O. D., on orders exceeding $\$ 10$ oo, if 25 per cent. of the amount is remitted with order. Caunot ship C. O. D. by freight.

Write Address Plainly. Write your Name, Post Office and State plainly, and in full on every letter. When Express or Freight Office is different from Post Office, advise me of the same.

Seeds, tc., by Wcight or Measure. Less than onequarler pound and one-quarter bushel will be charged at slight advance in price above pound and bushel rates.

Postal Service. The postal arraugements admit the sending of seeds to any part of the United States at the rate of eight ceuts a pound. I will send, postpaid, all Garden and Flower Seeds, sold in packets or by the onnce; but for Seeds in bulk, postage to the amount of eight cents per poind must be added to Catalogue prices. For postage on Peas, Beans and Corn add 15 cents per quart to Catalogue prices.

Market Fluctu itions. Prices are subject to variation without notice, on extreme changes in market values.

About Uarranting Seed. I do not warrant Seeds in any sense of the term, and while I consider the goods I sell of superior order and quality, and exercise the greatest care to secure only pure and reliable seeds, the fact is pertineut and undeniable that crops may fail, no matter how fresh or pure the seeds sown to produce them may be, owing to causes the most expert cultivator caunot control. Therefore, if the purchaser does not accept the seeds on these ternis and conditions, they must be returned at once, and the money that has been paid for the same will be refunded. 


\section{New and Valuable Varieties}

\section{Worthy of Special Consideration.}

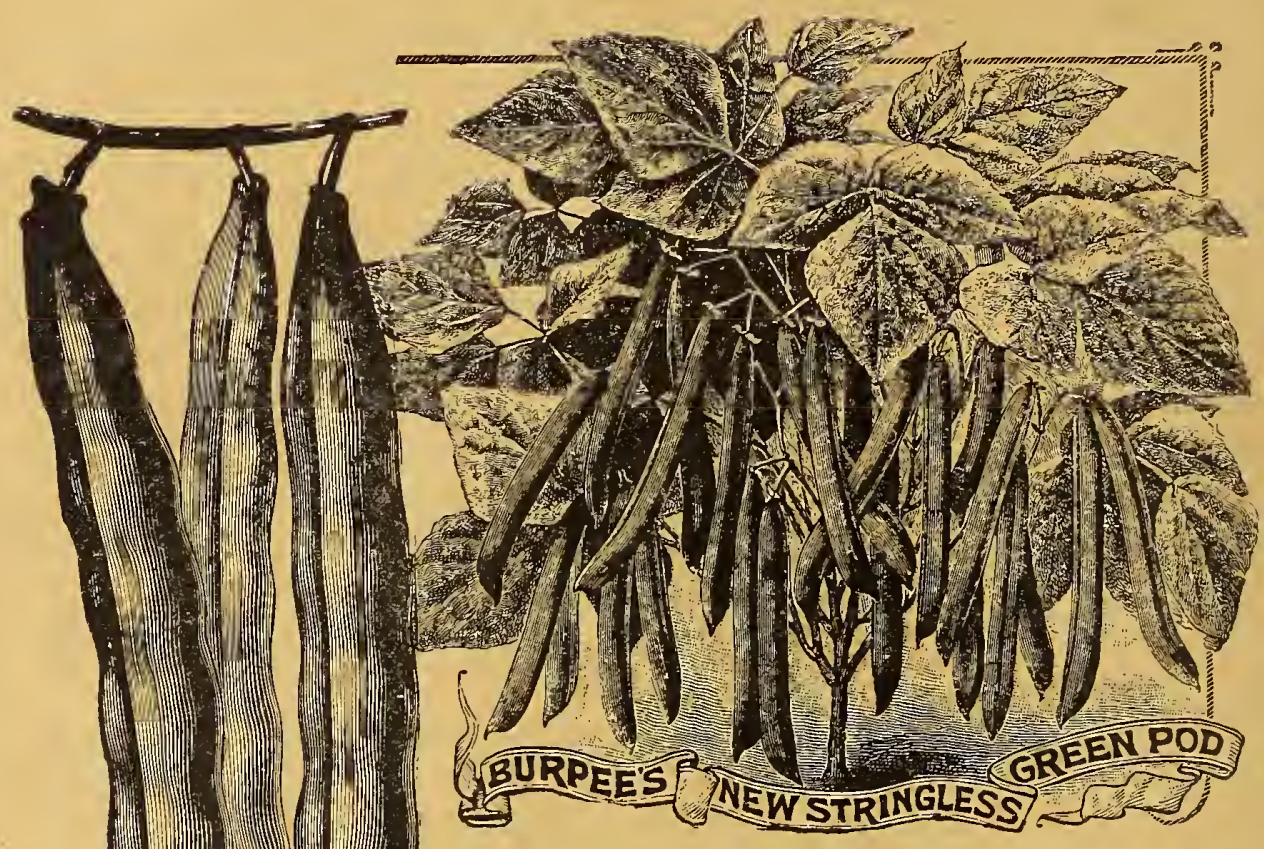

\section{Round}

Stringless Green

\section{Pod \\ Bean}

Is the on I y Stringless Green Pod Bush Beau i11 cultivation. The pods are round, $10 \mathrm{~g}$ and large, and ready to niar ket two weeks earlier than the best stock of Improved Extra Early Red Varieties. Price per pkt., Ioc; per qt., 3oc.; per peck, $\$ 1.75$; per bu., $\$ 6.00$.

\section{ALLAN'S IMPERIAL WAX.}

Pods long, broad and straiglit, of beautiful waxy color with fine texture and ñavor. We have the large, handsome pod so much admired in the flageolet class, combiued with a vine that is vigorous and healthy. Pods must be picked when young and tender, as they quickly grow tough by remaining too long on the vines. Seed white, splashed with chocolate brown, differing in marking from Golden Wax or any other variety. Price per pkt., roc.; per qt., 30c.; per bu., $\$ 7.00$.

\section{$\checkmark$ GRIMSON GLOBE BEET.}

This is a new comer of considerable merit. It is almost spherical, with small tops and root. The flesh is fine grained, dark crimsou color, with skin of lighter shade, making it very attractive as bunched for the market. While not one of the largest type, it grows to good size and is very early. Price per pkt., 5 c.; per oz., r5c.; per 1b., 8 oc.

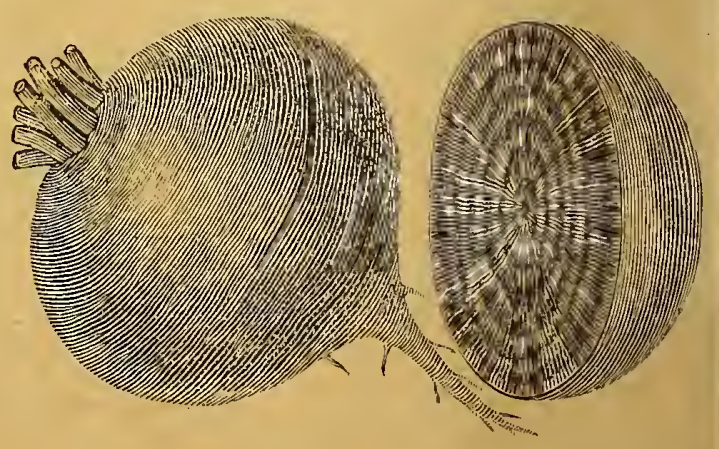

Crimson Gtobe Beet. 


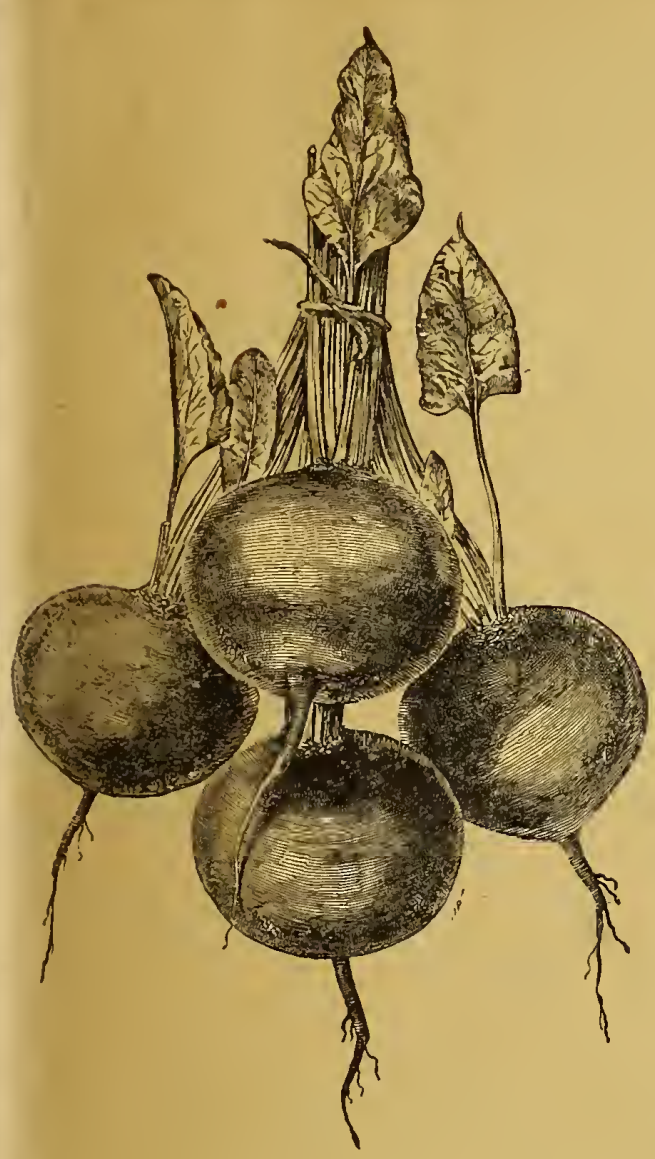

Jirigo Beet.

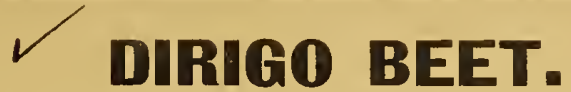

A very dark red early variety of the Egyptian type, though differing in the point of thickness, being but slightly flattened top and bottom and having a very smooth clean root. Price per pkt., 5c.; per.oz., Ioc.; per 1b., 6oc.

\section{$\checkmark$ Rivenhall Giant Yellow Mangel.}

A new type of intermediate form, very large in circumference and longer than the Globe varieties. Stands about half out of ground. The color is a light yellow, and it is an enormous cropper. In lots of Io lbs., 25c.; per oz., $5 \mathrm{c}$; per $1 \mathrm{~b} ., 30 \mathrm{c}$.

\section{TRIUMPH WATER MELON.}

A very large and valuable southern variety that comes to our markets in July. Rind dark green color. Seed large and dark; flesh is the briglit red color of Kolbs Gem. It is very e a $1 \mathrm{y}$, large, prolific, deliciously sweet, of fine flavor. Price per pkt., 5c.; per oz, Ioc.; per 1b., \$r.oo.

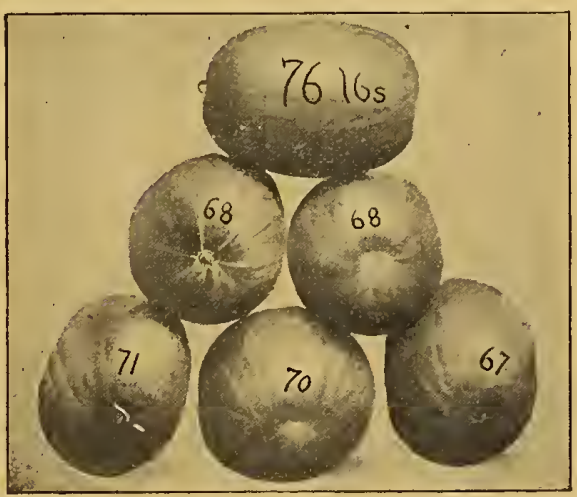

Triumph Water Melon.

\section{METROPOLITAN SWEET CORN.}

We have it and you want it. If a Market Gardener, you cannot run through the corn season without it, as it is the earliest, sweetest and biggest yielder of all the earlies; sets two and three ears to the stalk and is ininune to fungus. Who would not pay double for a corn as early as Cory, twice as large, and so far superior in quality to make comparison ridiculous, and with all this free from smut?

It is indispensable to the family garden because of its long duration in the edible state, combined with all its good points noted above.

One of our customers who planted it last season informed me that he planted at the same time Cory and Crosby, and picked Metro= politan for the $\mathrm{tab} l \mathrm{e}$ with the Cory and before the Crosby was developed sufficiently for use, thus establishing a record for the new variety, which is certainly a new century marvel. Its full set, 1 a rge kernels - ten to twelve rows-and ears eight to ten inches long, place this at once foremost anlong all introductions of recent date. Price per ear, 5 c, ; per qt., 3oc.: per pk., $\$ 1.50 ;$ per bu., $\$ 500$.

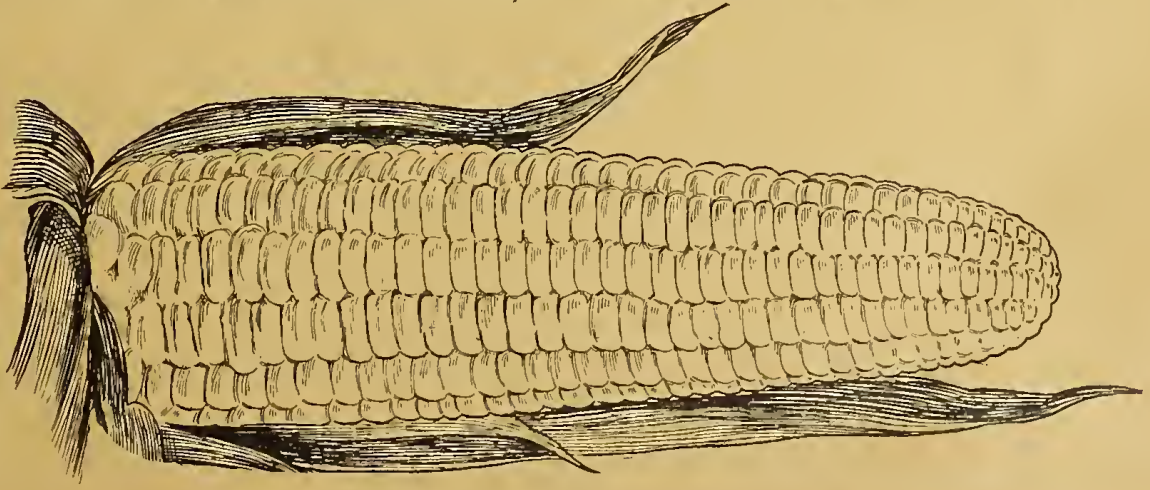




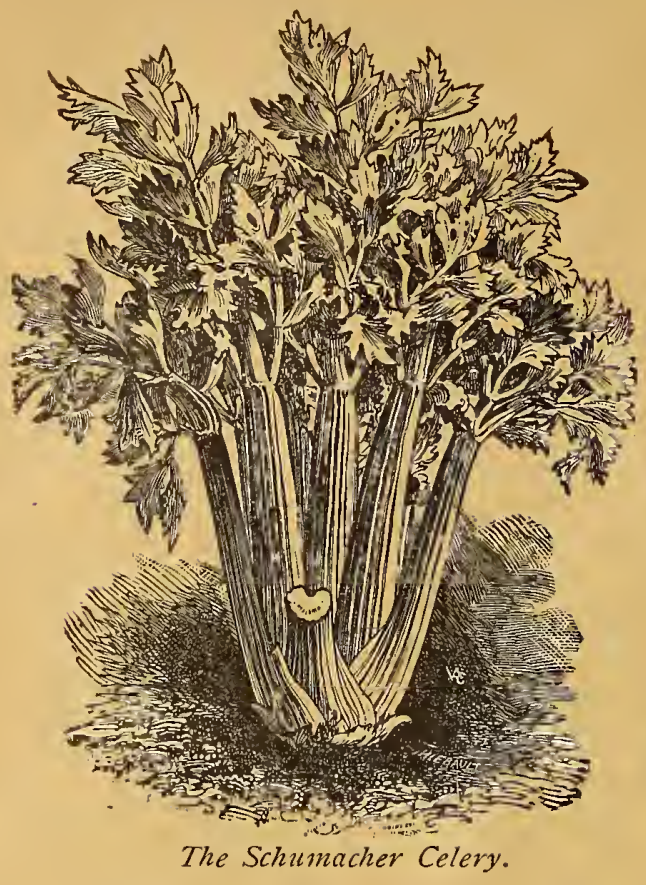

\section{THE EARLY GHAMPION SWEET CORN.}

This is a variety of more than ordinary value to the Market Gardener. Upon the recommendation of the originator - one of the largest and oldest growers of sweet corn for seed in the United States-I made a planting of it in my trial grounds a few years ago, and also offered it for sale to a number of gardeners, who unhesitatingly pronounced it the best second early of the list. I u my comparison I found it a few days later than the Burbank's Early Maine and Cory, but follow. ing close on. We picked the Champion and Extra Early Crosby on the same day. The ears are so much larger and longer than early sorts that it at ouce commands attention. It is ten to twelve rowed, well rounded at each end, and the quality is superb. It is pure white with kernel deeper than the average early variety, very sweet, tender, and delicious. Price per ear, 4c.; per qt., 20c.; per bu., $\$ 3.00$.

\section{The Schumacher Gelery.}

The Schumacher Celery supplies a variety to the grower that has long been wanted. It is a strong grower with a large solid golden waxy colored center, so hard and crisp that it has proved one of the best keepers we have, and for market gardeners it is particularly desirable. Its heavy outer stalks serve as protection, prevent evaporation, and hold the center in a fresh, crisp condition long after, for winter use. Price per pkt., 5c.; per oz., 30c.; per 1b., \$3.00.

\section{THE EMERALD GUCUMBER.}

Livingston's Emerald possesses a rich, dark green color and spineless skin. The fruit sets early, and its vigorous vines abound in long, straight, handsome fruits of the most desirable qualities. As a slicer, the flesh is peculiarly crisp and tender, and the flavor most pleasing. Th e young fruit being dark green, straight and tender, makes an excellent pickle, and when ripe none excels it for making sweet

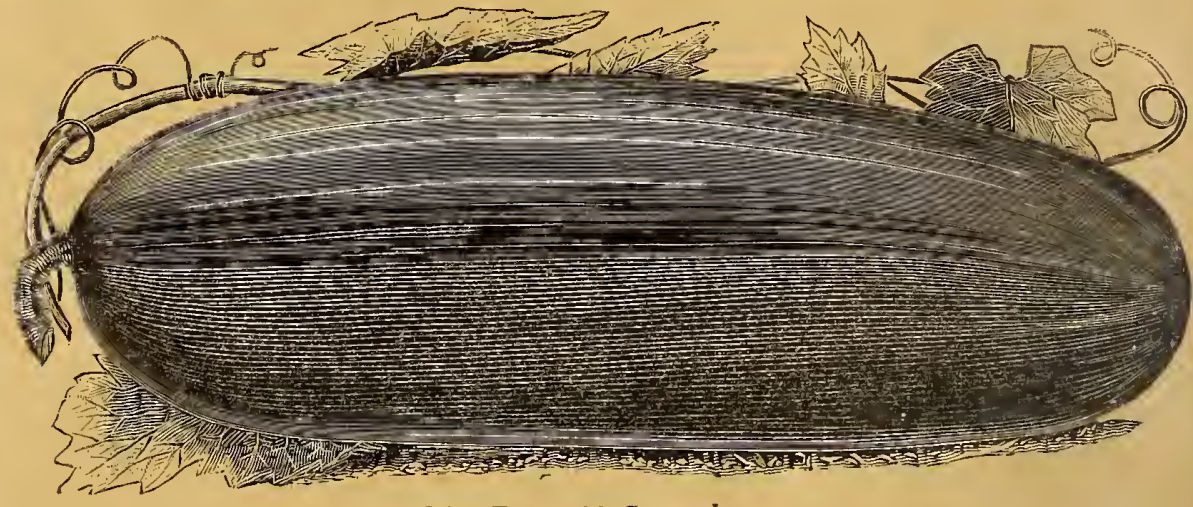

The Emerald Cucumber. pickles.

For Forcing. For those who grow under glass, or for long distance shipping, it will prove a boon, on account of holding its deep green color so long; besides, its size and uniformity will suit such growers much better than many of the kinds usually recommended for this purpose. It is almost free from "warts and spines," so much so that it may be called spineless. As an all purpose table or market variety, whether for gardeners' or farmers' use, it cannot be surpassed. Price per pkt., 5c.; per oz., I5c.; per 1b., \$1.oo.

\section{Florence or Naples Fennel.}

This is a variety of the fennel family that is cultivated for its leaf stalks like celery, growing heavy at the base and almost forming in bulb form. It has a peculiarly agreeable flavor and is highly esteemed by the sons of Italy, either raw or cooked. Price per pkt., 5c.; per oz., 15c.; per $1 \mathrm{~b} ., \$ \mathrm{I} .75$.

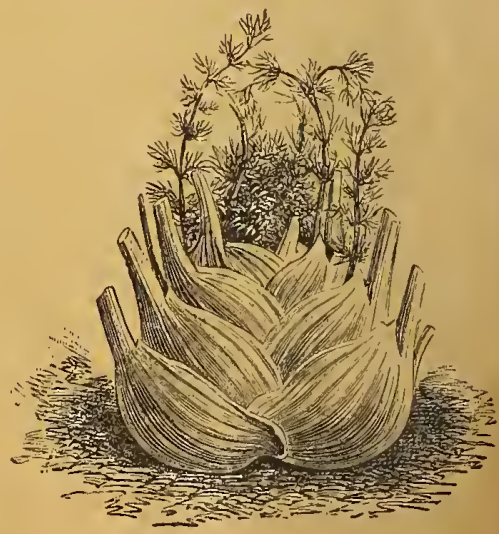

Florence or Naples Fennel. 


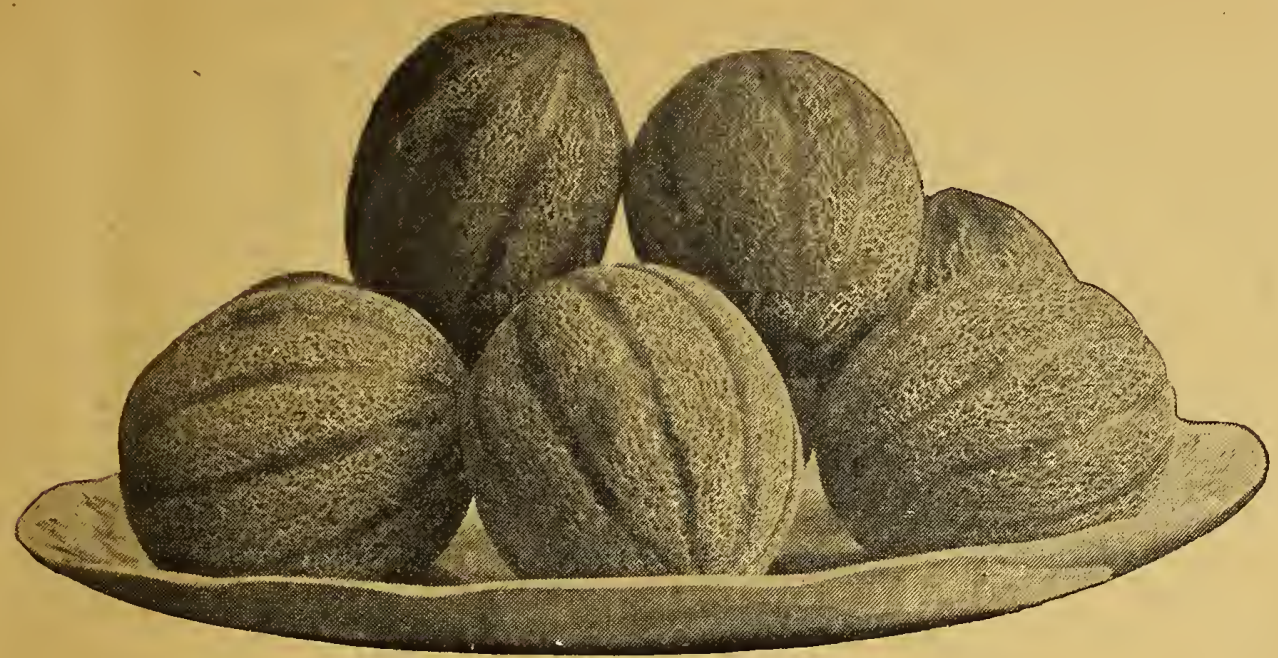

Rocky Ford Muskmelon or Canlaloupe.

\section{Rocky Ford Muskmelon or Cantaloupe.}

It is of the Netted Gem type, oval in shape, averaging from four and one-half to five inches in length, of a delicate flavor, very fine and smooth grained flesh, of a light green color throughout when ripe, and is the most attractive and popular cantaloupe now on the market. This variety derives its name from the district in which it has been for the past two years so extensively and successfully grown, in " Rocky Ford," Colorado, and from which point these melons are shipped in their season by the car load to nearly every station in the United States. Price per pkt., 5c ; per oz., Ioc.; per 1b., $80 c$.

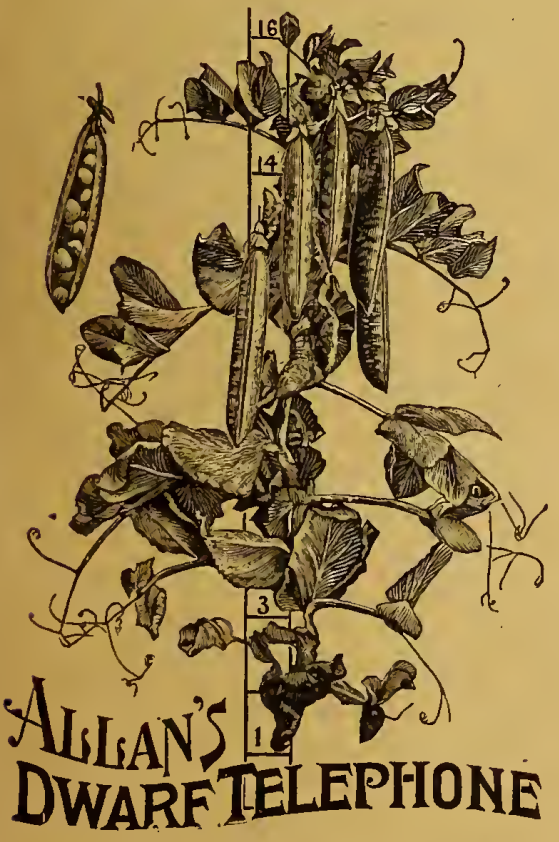

\section{DWARF TELEPHONE PEA, Sometimes called Carter's Daisy.}

It is recommended as equal to the Carter's Telephone in every particular, which it closely resembles, except in length of vine and time of maturity. It is said to be nearly two weeks earlier than its namesake, growing but eighteen to twenty-four inches in height and requiring no supports even in garden culture. The pods very large, long and well filled. Price per qt., 40c.; per pk., $\$ 2.00$; per bu., $\$ 7.50$.

\section{An Extra Early Wrinkled Pea. \\ Gradus.}

The earliest large wrinkled pea up-to-date, traveling under several aliases, viz.: "Prosperity," "Early Giant," and "Extra Long Pod." Nearly the size of Telephone and possessing all its delicious qualities.

The vine is about three feet in length, foliage light green, and yield beyond all rivals. Maturing but three or four days after the round, hard, early June varieties, and surpassing them in every point of excellence. Price per qt., 35c.; per pk., $\$ 2.5^{\circ}$; per bu., $\$ 9 . c o$.

\section{PEAS--Nott's Perfection.}

Richard Nott, its originator, said: "I have been carefully developing this Pea since my Excelsior was sent out several years ago, and I can confidently reconimend it as superior to the Excelsior, goor as that variety is now universally admitted to be. It combines the best qualities of its parent stocks (Premium Gem and Nott's Excelsior) with many distinct merits of its own Is quite as early as the Excelsior, hardier, more productive, and of finer quality. Grows from fourteen to sixteen inches high, and pods liberally, each pod containing from six to eight fine large peas, remarkably sweet and rich in flavor."

Price per pkt., I5c.; per qt., 4 oc.; $1 / 4$ bu., $\$ 2.25 ;$ per bu., $\$ 8.00$. 


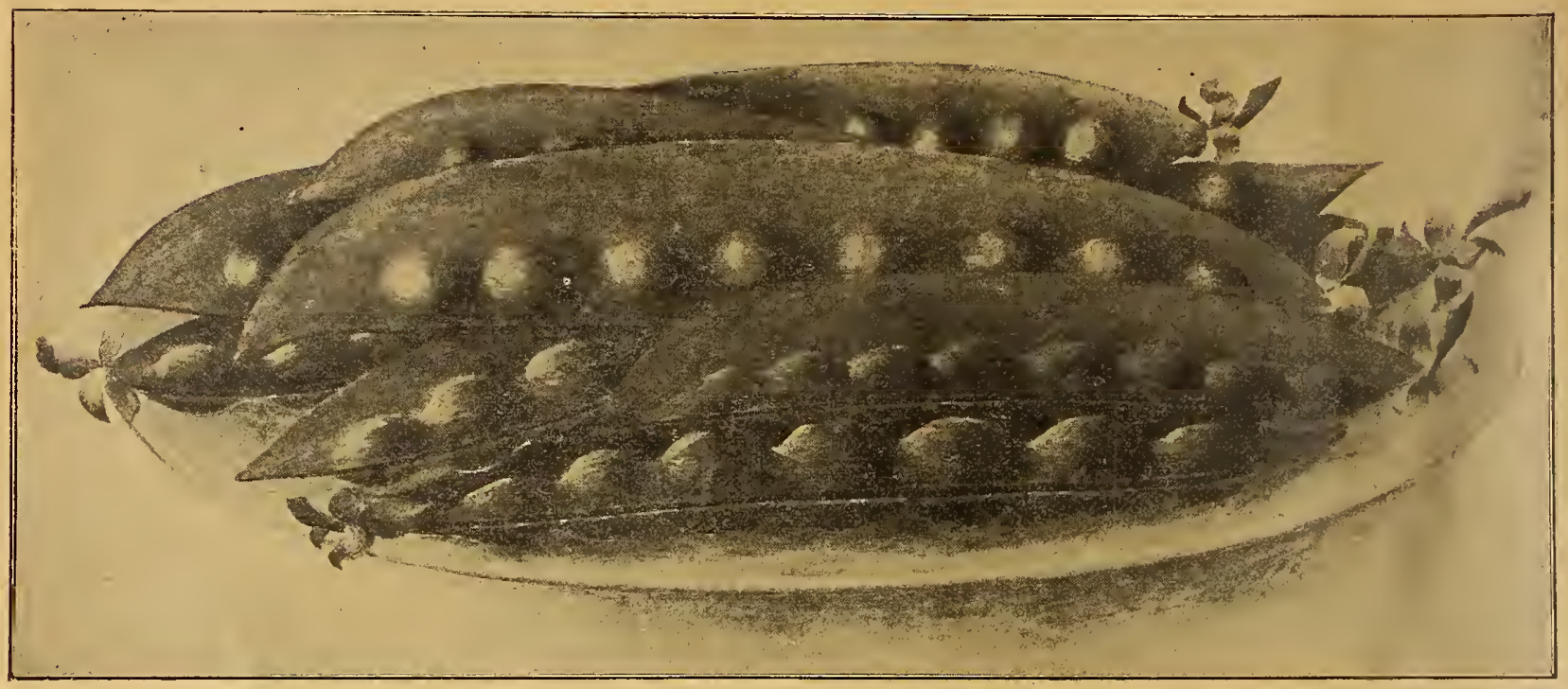

Livingston's Prolific Giant Podded Sugar Pea.

\section{Livingston's Prolific Giant Podded Sugar Pea.}

'This new edible podded pea excells all others in size, productiveness and quality. The vines average about thirty-six inches in height and remain a long time in bearing. The pods are gigantic in size, broad, sweet and tender, extremely fleshy and equal to the best snap beans for cooking pods and all. Price per qt., 40c.; per pk., $\$ 2.25$; per bu., $\$ 8$ oo.

\section{NEW "ICICLE" RADISH.}

This Radisl derives its name from the transparent whiteness of the root. In form it is long and slightly stump-rooted. The leaves are short aud its flavor the very best. The roots grow about four inches long and are ready for use within twenty-two days from the time of sowing. It is a desirable variety for the home garden, and market gardeners will find it a money maker. Price per pkt., Ioc.: per oz., 20c.; per $1 / 41$ lb., 6oc.; per 1b., \$2.00.

\section{NEW RADISH TRIUMPH.}

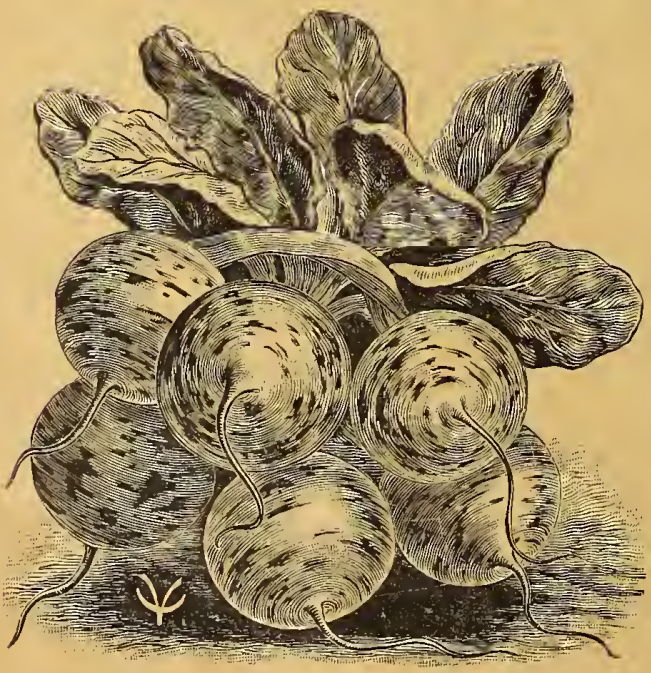

It is very early, being a "Twenty Day" Radish, a $1 \mathrm{mos}$ t perfectly round and its tops are very short, which makes it valuable for cultivation under glass. The flesli is very crisp and solid and of mild flavor. Its most distinctive feature, however, is the unique color of the skin. The ground color is pure white, striped horizontally with bright scarlet; some roots are peppered with crimson, others splashed here and there.

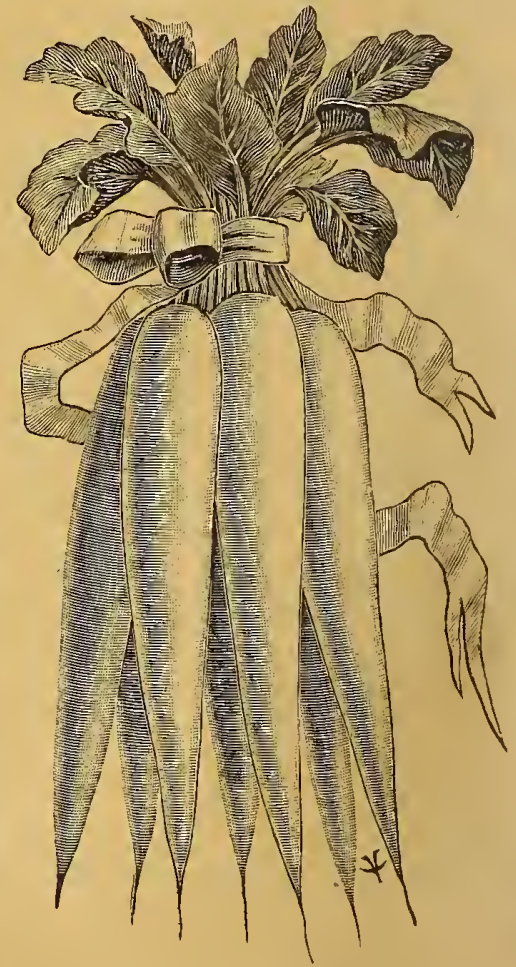

New Icicle Radish.

New Radish Triumph. The radishes average about an inch in diameter. Price per pkt., IOc.; 3 pkts., 20c.; oz., 30c. 


\section{SGARLET KASHMYR.}

A new and entirely distinct Turnip. The outer color is rich scarlet, while the flesh is snow-white. It is an extra early sort, small, rarely exceeding three inches in diameter, and flat; the leaves are small, full and strap-leaved; the flesh is very solid, tender, finegrained and of good quality. Price per $1 \mathrm{~b} ., 75 \mathrm{c}$; per 1/4 lb., 25c.; per oz., Ioc ; per pkt., 5c.

\section{Golden Bronze Squash.}

Mr. Lowe, who originated this squash, thus describes it: "A cross of the Bay State and Boston Marrow. 11 form the same as the last uamed, with stem and blossom end precisely like that variety. Size averaging from eight to ten pounds; color, a dark, grayislı green; flesli, an exceedingly bright golden yellow; fine grained, very sweet. Early in maturing, a good keeper, and yielding largely of squashes of very

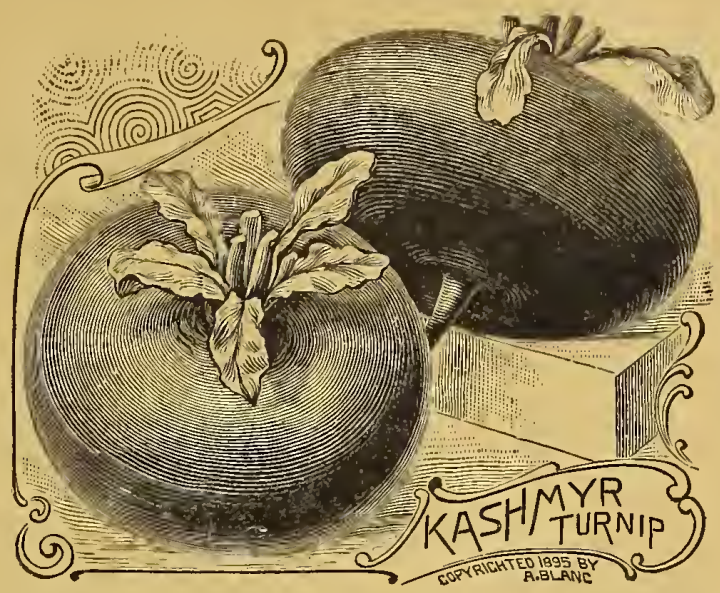

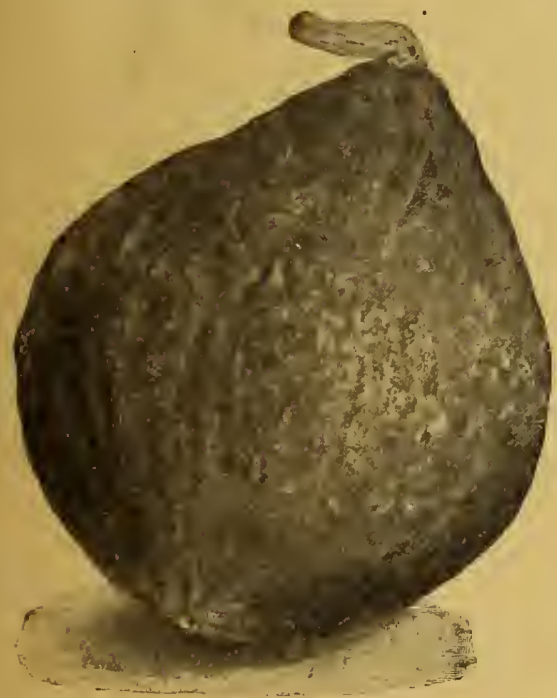

Golden Bronze Squash.

uniform size and appearance. As a squash, combining the qualities desired for the table aud pies, this has no superior. Specimens grown in $\times 897$ were kept until Jume, I898." Price per pkt., 5c.; per oz., I5c.; per 1 h., $\$$ I.50.

\section{COCOZELLA SQUASH.}

This Italian Squash grows about twenty.two inches long, witl a dianteter of about four inches. The skin is smooth, of a dark green color, marbled yellow or paler green, of very rapid growth, and fine flavored. In Italy it is quite a favorite, aud is eaten when very young. Price per pkt.) 5c.; per oz., Ioc.; per lb, goc.

\section{DELICATA SQUASH.}

This little squash resembles in color and quality the "Cocoanut," but is elongated, growing from five to eight inches long. It is slightly ribbed, orange yellow color, mottled and striped with green. The quality is superb, beiug very solid, dry and sweet. Price per pkt., 5c.; per oz., Ioc.; per lb., 6oc.

\section{Clark's Pride Potato.}

This is a valuable early variety that originated with Mr. Humphrey Clark, of Washburı, Maine, and has taken first position without much arlvertisiugalthough under the name of "Ensign Bagley" some of our local growers had an opportunity to prove its merits. It is one of the largest early potatoes that we have; smooth, white surface, with few eyes, oval in shape, fine graiued, and very prolific. My stock is all from Maine, and produced by a party who purchased the seed from the originator. Price per $p k$, 5oc.; per bu., \$r.50; per bbl. or sack, $165 \mathrm{lbs}, .3 .50$.

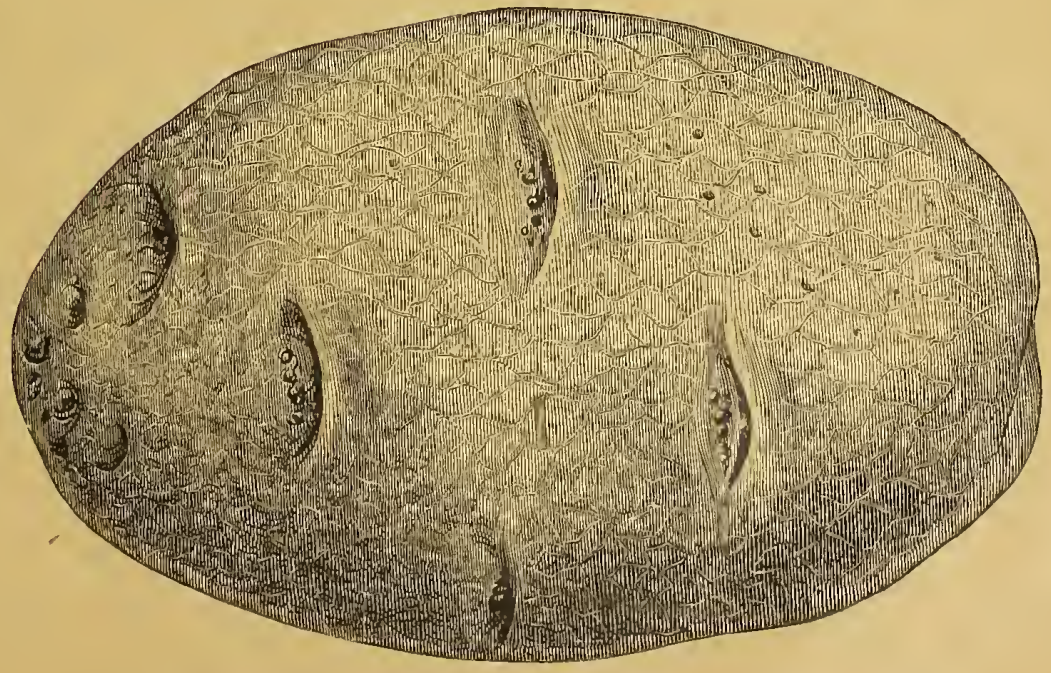

Clark's Pride Polale, 


\section{LIVINGSTON'S “MAGNUS" TOMATO.}

The introducer recommends "Magnus" as follows: "A very distinct and most promising new variety, of the color of Beauty and Acme, is the latest addition by Livingston to the Tomato family. It is thicker, heavier and more solid than either Acme or Beauty. It is unsur. passed in quality, and in the production of fine, large fruits. While perfectly adapted to main crop planting, yet it ma tures so quickly that it will take first rank for early market. The form is perfect, uniform, large and attractive. Flesh is very firm. It is a robust grower,with short joints, setting its fruit clusters closer together than most varieties, and it is therefore a heavy cropper. The fruits are very deep from stem to blossom end, many of them being almost globeshaped. It ripens even$1 v$, does not crack about the stem, and the flavor is most desirable. We have tested it for several years for staking up in the open field, as well as

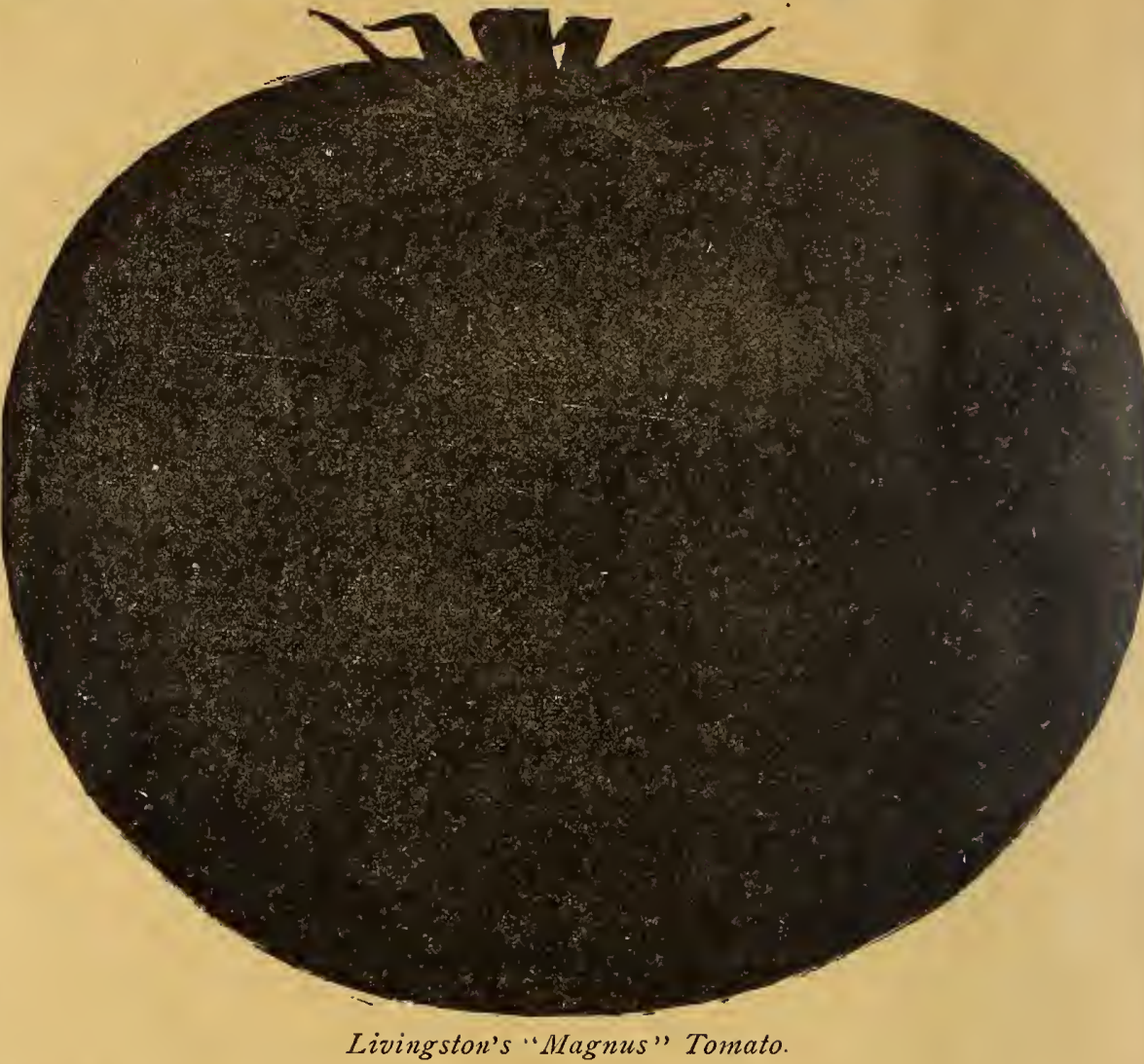
for forcing in greenhouses, and we believe it to be entirely nnequalled for sucl purposes." Price per pkt., Ioc.; per oz., 5oc.

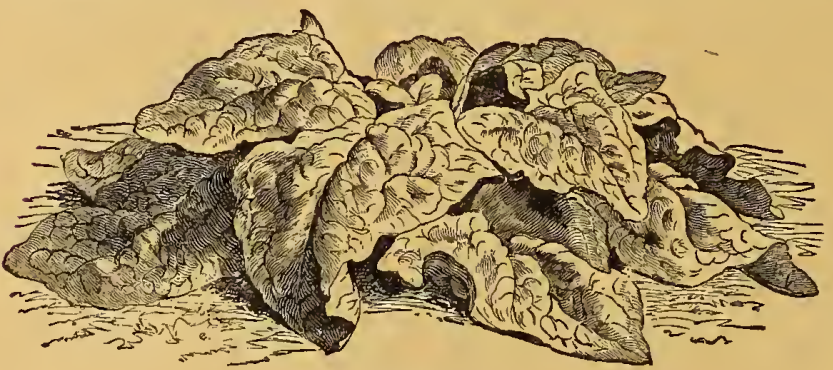

Victoria Spinach.

\section{VICTORIA SPINAGH.}

Although we have sold this strain of Spinach for two seasons, it seems to possess merits that entitle it to remain among the list of specialties. This is a German type of the large crumpled leaf Spinach and is exceptionally desirable for spring sowing, owing to its extreme vigor and size, and its long resistance to the stalking up propensity so fatal to the reputation of other large sorts. The color is a rich dark green. The leaf is crumpled and curled to a degree of beauty. Price per pkt., 5c.; per oz.,Joc.; per lb., $40 \mathrm{oc}$.

\section{WHITE EGG TURNIP.}

The White Egg Turnip is no stranger, being numbered among my first introductions, but the fact of its superiority having been so thoroughly appreciated as to tempt other dealers to bring it out again under the name of Early Snowball is sufficient evidence that all the recommendations of its introduction have been realized. Price per pkt., 5c.; per oz., Joc.; per 1b., $40 \mathrm{c}$ :

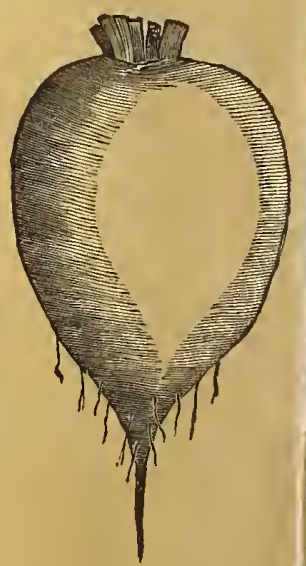

White Egg Turnip. 


\section{GENERAL LIST}

\section{of \\ Select \\ Vegetable

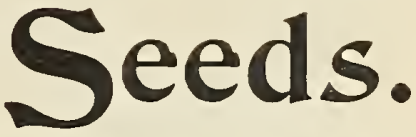 \\ ASPARAGUS.}

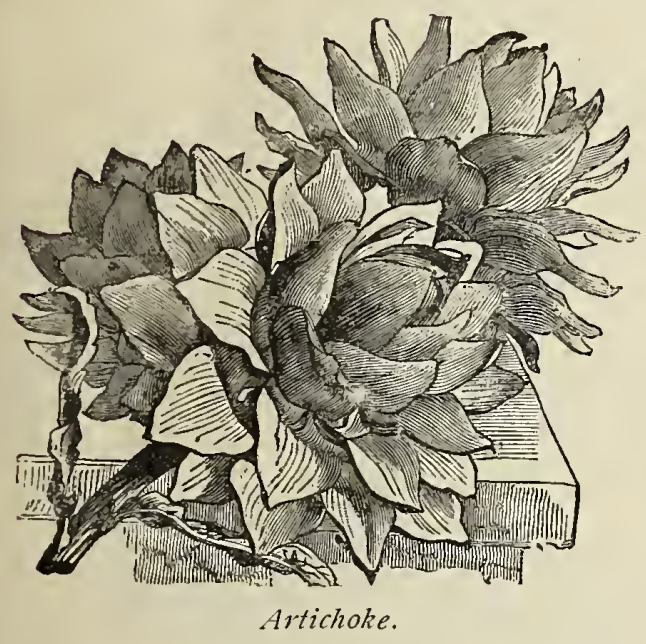

\section{ARTICHOKE.}

(Artischoke-Carciofo-Alcachofa.)

Large French Globe. The flower heads of this variety are the portions for the table. Sow early in spring, in rich soil, and transplant the following spring to permanent beds, in rows (or hills) three feet apart, and two feet between the plants. It requires a deep, rich loam, and should be protected in winter by a covering of leaves or coarse manure. Perennial. Price per pkt., loc.; per oz., 3oc.

Tuberous=Rooted Artichoke. Jerusalem Artichoke. This is quite distinct from the Globe Artichoke, being grown exclusively for its tubers. Price per lb., IOc, 3 lb., 25c.; per pk., $\$ 1.00$; per bu., $\$ 3.50$.

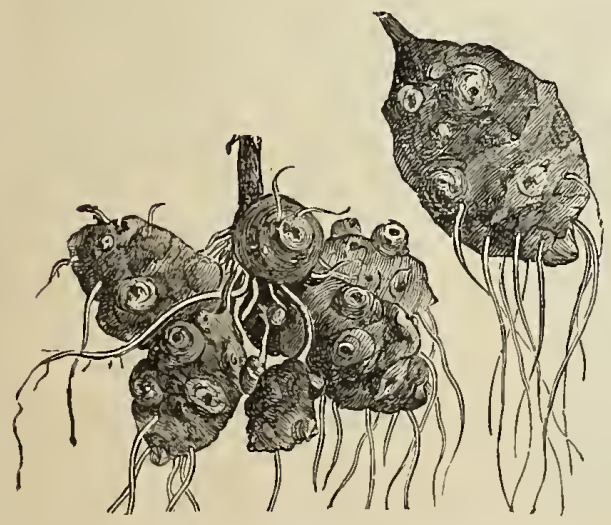

Tuberous-Rooted Artichoke.

Spargel-Esparrago-Asparago.

Sow the seed early in the spring, in drills about one inch deep, and rows about a foot apart, and in the fall or the succeeding spring the plants may be set out

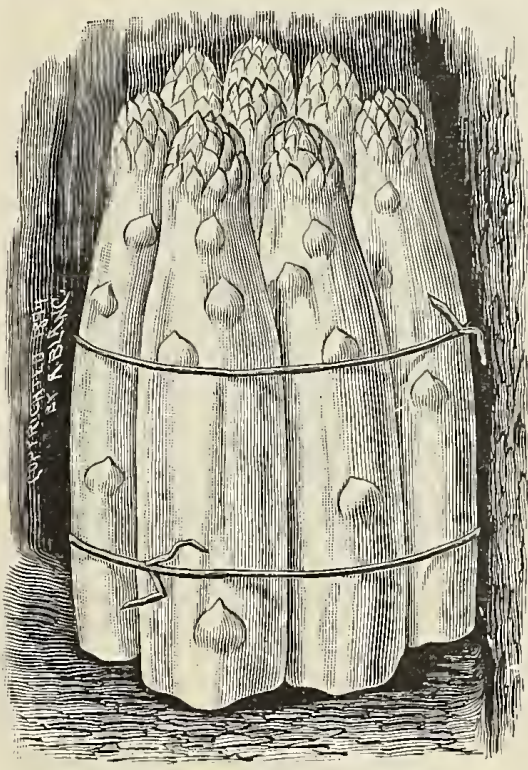

Hsparagus.

in beds about two feet apart each way, leaving the crown of the root about four inches below the surface. Before winter. cover the bed with a dress. ing of manure. Purchasing roots instead of seed will save a year in time.

PaImet to. Very early.large and pale green. Price per pkt. 5c.; per Oz., loc. per 1b., $40 \mathrm{c}$.

Barr's Mammoth. Very large, t e n de stalks, light col or and very early. Price per pkt., sc.; per oz.

Conover's Colossal. La ge, early, green and very prolific Price per pkt., 5c.; per oz., 10c.; per lb., 4oc.

Columbian Mammoth White. A large white variety maturing early. Pr ce per pkt., $5 \mathrm{c}$; peroz,, roc.; per lb., soc.

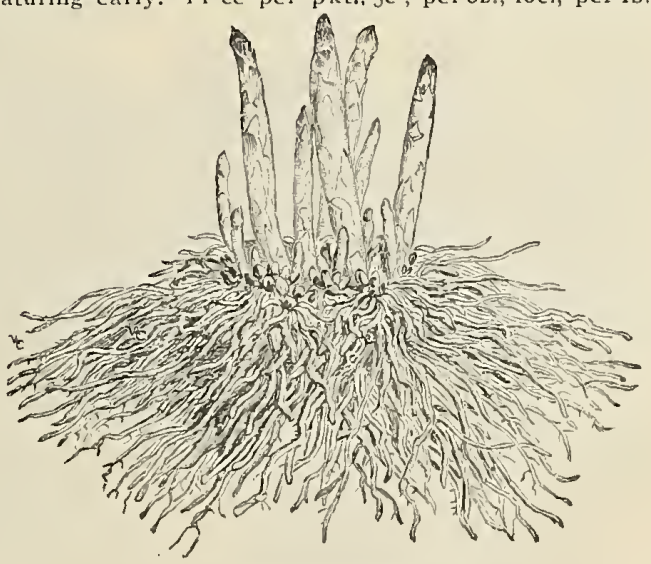

Asparagus Roots

\section{Asparagus Roots.}

Conover's Colossal, t-yearold, Conover's Colossal, 2-years old Palmetto, 2-years old. Barr's Mammoth, Colnmbian Mammoth white,
$100, \$ .50 ; 1000, \$ 3.50$
$100,1.00 ; 1000,5.00$
$100,1.00 ; 1000,5.00$
$100,1.00 ; 1000,5.00$
$100,1.00 ;$ 


\section{BEANS--Dwarf, Bush or Snap.}

WAX POD VARIETIES.

Bohnen-Frigoles-Faggioli.

A succession of sowing can be made from the first week in May until August. Plant in drills about two inches deep and from eighteen inches to two feet apart, according to the richness of the soil. The plants should be about three inches apart.

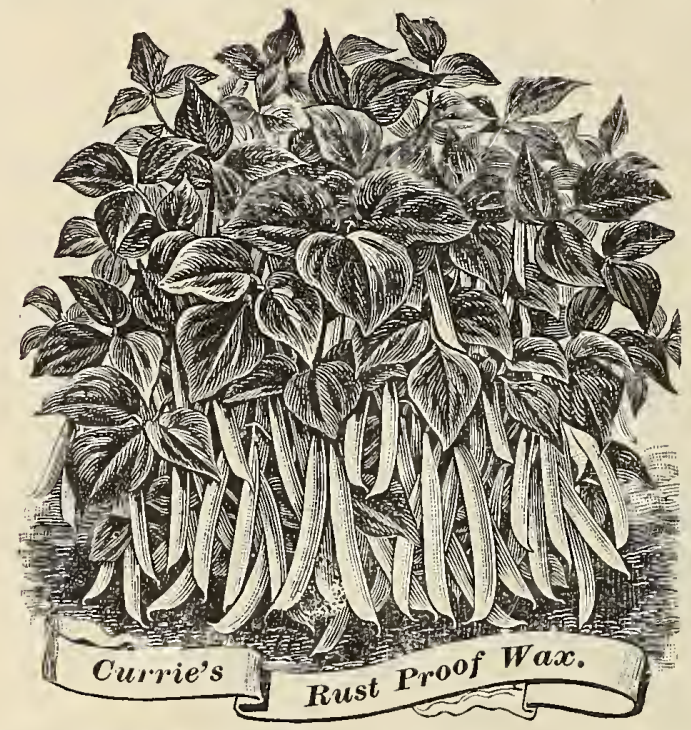

Allan's Imperial Wax. (See Novelties, page 2.) Price per qt., 3oc.; per bu., $\$ 7.00$.

Keeney's Rustless Golden Wax. The pods are thick, flat when young, and semi-round later; of rich yellow color. Price per qt., $30 c$; per bu., $\$ 5.50$.

Currie's Rust Proof. Pods long, flat and straight, of a beautiful golden color. Price per qt., 3oc.; per bu., $\$ 6.00$.

Davis Wax. A rustless, wax bean, pods flat, long and straight, seeds clear white. Price per qt., zoc.; per hu., $\$ 6.00$.

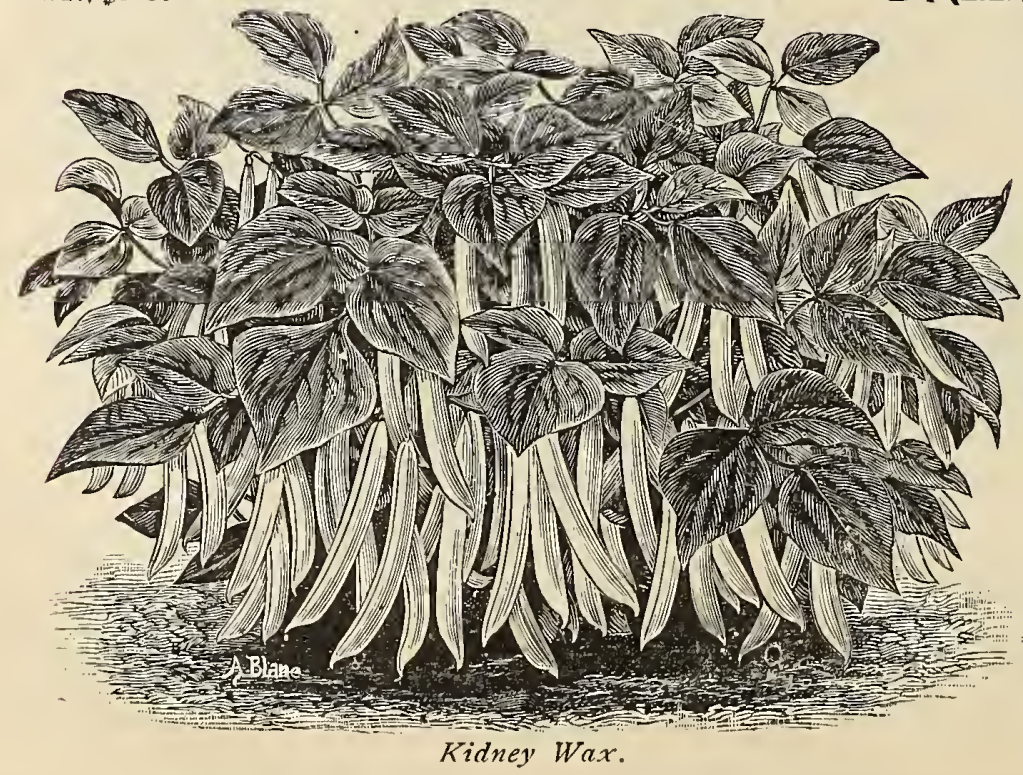

Kidney Wax. Pods long, broad, flat and of a delicate waxy yellow. Beans white, mottled with purple. Price per qt., 3oc.; per bu., $\$ 6.00$.

Yosemite Mammoth Wax. The pods are large, plump and pulpy, nearly round, bright golden color. Price per qt , 4oc.; per bu., $\$ \delta .0 o$.

Golden=Eyed Wax. An early variety, pods flat and of a beautiful waxy appearance. Price per qt., 3oc.; per bu., $\$ 5.00$.

Dwarf Golden Wax. Véry early; entirely stringless, and of a rich golden color. Price per qt., 30c.; per bu., $\$ 6.00$.

Grenell's Improved Golden Wax. A rust-proof variety, pods long, straight and thick. Price per qt., 3oc.; per bu., $\$ 5.50$.

Black Wax or Butter. An excellent string bean. The pods, when ripe, are round, waxy, yellow. Price per qt.. 3oc.; per bu., $\$ 5 \cdot 50$.

Challenge Black Wax. An extra early strain of the Dwarf Black Wax. Price per qt., 3oc.; per bu., $\$ 5 \cdot 50$. White Wax. Pods flat, yellow and good every way. Price per qt., 3oc.; per bu., $\$ 6.00$.

\section{BEANS-Dwarf, Bush or Snap. GREEN POD VARIETIES.}

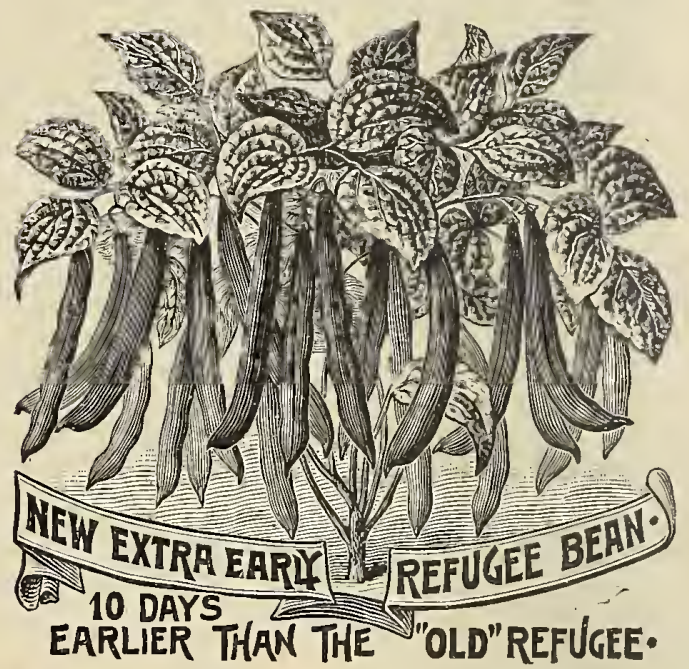

Round Green Pod. Stringless (See

Novelties, page 2). Price per qt., 3oc.; per bu., $\$ 6.00$.

Extra Early Refugee. Round pods, dark-colored seerl. Price per qt., 25c.; per bu., $\$ 5.00$.

Extra Early Valentine. Improved round pod Red Valentine. Price per qt., $25 \mathrm{c}$; per bu., $\$ 5.00$.

Early Long Yellow Six Weeks. Long flat pods, seeds yellow. Price per qt., $25 \mathrm{c}$; per bu., $\$ 5.00$.

Early China Dwarf or Red Eye. Very early, pods flat. Price per qt., $25 \mathrm{c}$.; per bu., $\$ 5.00$.

Refugee or Thousand=to=one. Late, round pod, dark seed. Price per qt.. 25c.; per bu., $\$ 5.00$.

Mohawk. Long flat pods, one of the best for fall use and pickling Price per qt., $25 \mathrm{c}$; ; per bu., $\$ 5 \cdot 00$.

Dwarf Horticultural. Large round beans in proportionately fine large mottled pods. Price per qt., 3oc.; per bu., $\$ 5 \cdot 50$. 


\section{BEANS-continued.}

\section{GREEN POD VARIETIES.}

Warren Bush Broad, flat pods, seed large, oval, thick, purplish brown. Price per qt., 3oc.; per bu., $\$ 5 \cdot 50$.

Boston Favorite. (Large Goddard.) Red podded Dwarf Horticultural. Price per qt.. 30c.; per bu., $\$ 5.50$.

Large White Kidney or Royal Dwarf. One of the best shell beans, green or ripe. Price per qt., $20 c$.; per bu., $\$ 4.00$.

Red Kidney or Chilian. Generally cultivated as a field bean and used dry. Price per qt, ${ }^{5} \mathrm{c}$; per bu., $\$ 3.50$.

White Marrow. Best adapted to field culture and sale in dry state. Price per qt. I 5 c.; per bu, $\$ 3.00$.

White Field or Medium. A standard sort for field cultivation. Price per qt.. Ioc.; per bu.. \$2.50.

White Pea or Navy. The genuine Boston Baking Bean. Price per qt., Ioc.; per b11., $\$ 2.50$.

\section{ENGLISH OR BROAD.}

Broad Windsor. A bush or stump variety ; ripens unevenly, thus prolonging the season. Thrives best in good, rich, rather damp soil. Price per qt., $25 \mathrm{C} \cdot$; per bu., $\$ 5 \cdot 00$.

\section{BUSH LIMAS.}

Burpee's Bush Lima. It is a Cienuine Lima bean of bush habit, growing from eighteen inches to two feet high. Price per qt., 30c.; per bu., $\$ 7 \cdot 00$.

Dreer's Bush Lima. It grows about two feet high and is of branching habit, maturing early; the beans in a green state are not quite as large as the Large Lima, but grow closer together in pod and are thicker. Price per qt., 4oc.; per bu., \$9.0o.

Hendersoli's Bush Lima. Is a Dwarf-growing, flat podded variety, similar to the Large Lima, but sulaller. It is the earliest of the lima beans. Price per qt., 3oc.; per bu., $\$ 6.00$.
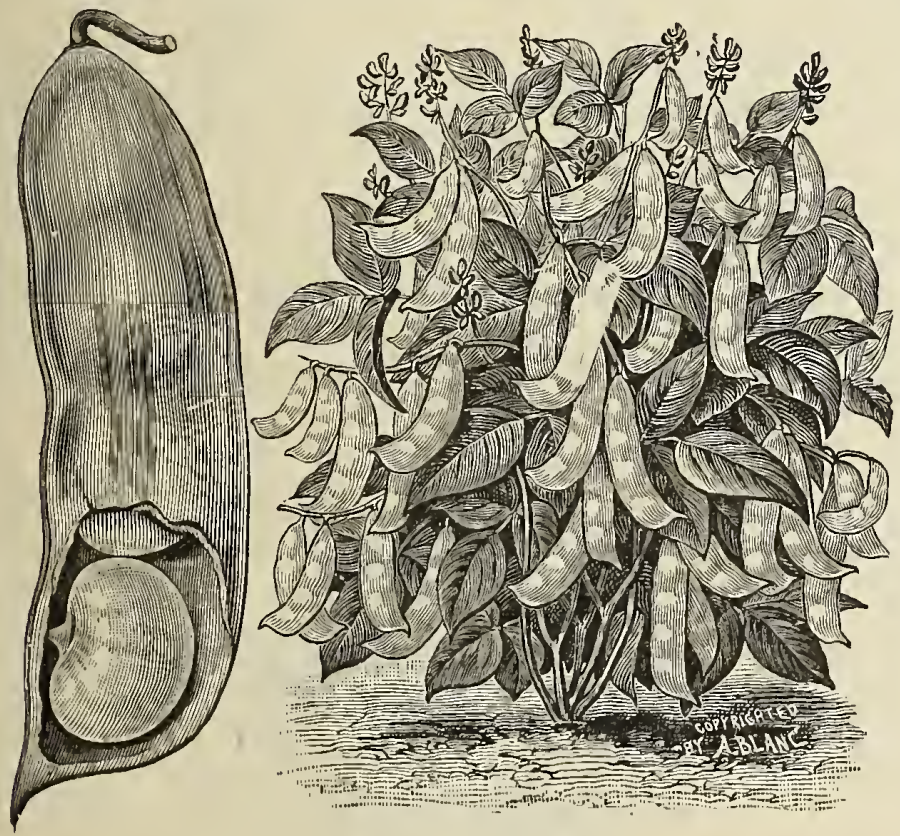

Burpee's Bush Lima.

\section{BEANS-mPole or Running.}

They succeed best in sandy loam, which should be liberally enriched with thoroughly rotted manure in the hills, which are formed according to the variety, from three to four feet apart.

King of the Garden Lima. Early and prolific; pods large and long, bearing four to seven beans, and quality without a rival. Price per $1 / 2 \mathrm{pt}$., Ioc.; per qt., $30 c$; per bu., $\$ 6 . \infty$.

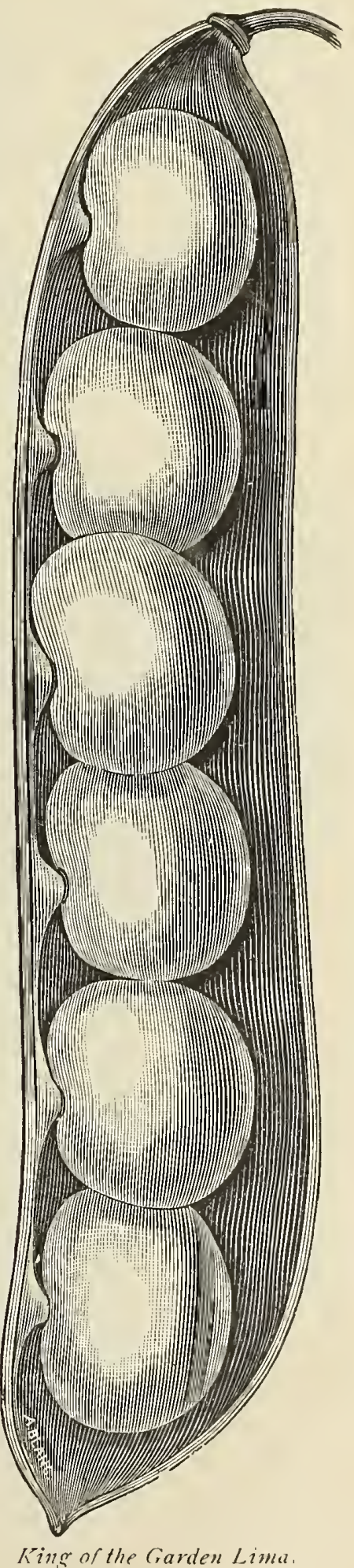




\section{BEANS-continued.}

\section{POLE OR RUNNING.}

Extra Large White Lima. This is selected stock of a large seeded strain. Price per $1 / 2$ pt., Ioc.; per qt., 30c.; per bu., $\$ 6.00$.

Large White Lima. Broad flat pods, containing several large white seeds. Price per qt., $25 \mathrm{c}$.; per bu., $\$ 5 \cdot 00$.

Seibert's Extra Early. This bean has proved the earliest Large 7 rue Lima we have. It is a large, thin. podded kiud, bearing three or four full-sized, large, white seeds; equal in quality to our best sorts. Price per $1 / 2$ pt., IOc; perqt., 30c.; per bu., $\$ 6.00$.

Small Lima or Sieva. Similar to Large Lima in shape and color, but smaller and earlier. Price per $1 / 2 \mathrm{pt}$, IO乞.; per qt., 3oc.; per bu., $\$ 6.00$.

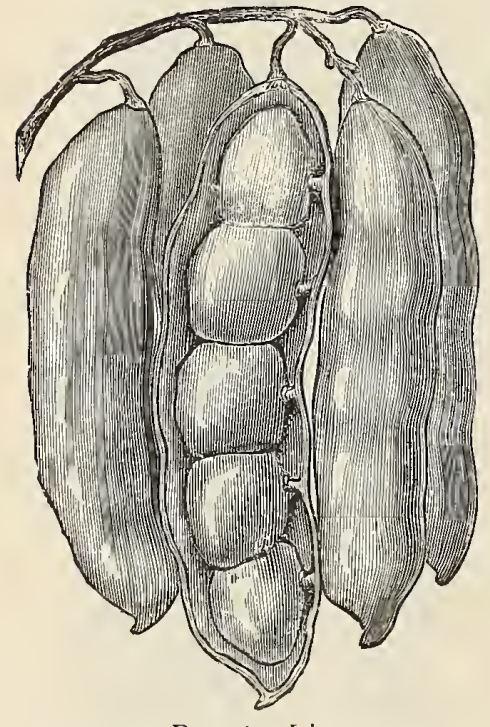

Dreer's Lima.
Dreer's Lima. Early and productive. $\mathrm{T} \mathrm{h}$ e bean is thick and rou nd, growing close in the pod. Price per $1 / 2$ pt., Ioc.; perqt., 3oc.; per bu., $\$ 7 \cdot 00$.

Scarlet Runner. The beans are very dark and the flowers bright scarlet. Price per $1 / 2$ pt., IOc.; per qt., 3oc.; per bu., $\$ 6.00$.

White Dutch Runner. Similar to the Scarlet Runner, except in flower and seed, which are white. Price per $1 / 2$ pt. I oc.; per qt., 3oc.; per bu., \$6.oo.

Dutch Case Knife. Early and prolific, long flat pods with white seeds; sometimes used as suaps, but generally shelled. Price per $1 / 2$ pt., Ioc.; per qt., 3oc.; per bu., $\$ 5 \cdot 50$.

London Horticultural or Speckled Cranberry. Pods striped with red, seeds oval, of medium size, used both in the pod aud shelled; good dry. Price per $1 / 2$ pt., IOc.; per qt., 30c.; per bu., $\$ 5.50$.

Kentucky Wonder or Old Homestead. Large, green pods, often measuring eight to ten inches, and one of the best green podded snaps of the catalogue. Price per $1 / 2$ pt., Ioc.; per qt., 30c.; per bu., $\$ 6.00$.

Early Golden Cluster. Pods are golden yellow, from six to eight inches long, borne profusely in clusters of four to six. Price per $1 / 2$ pt., I5c.; per qt., 4oc.; per bu., $\$ 8.00$.

German Wax, Black or Indian Chief. Seeds black and oval, pods yellow aud produced in abundance. Price per $1 / 2$ pt., Ioc.; per qt., 3oc.; per bu., $\$ 6.00$.

French Yard Long. Pods sometimes grow from two to three feet long; very curious; should be supported on brush. Price per pkt., Ioc.

\section{BEETS.}

Runkel Rübe-Remolacha-Bietoli.

The beet is used in all stages of its growth. All the varieties succeed best on a deep, rich, sandy loam, and require to be thinned when small and kept free from weeds. For early beets, sow as soon as the

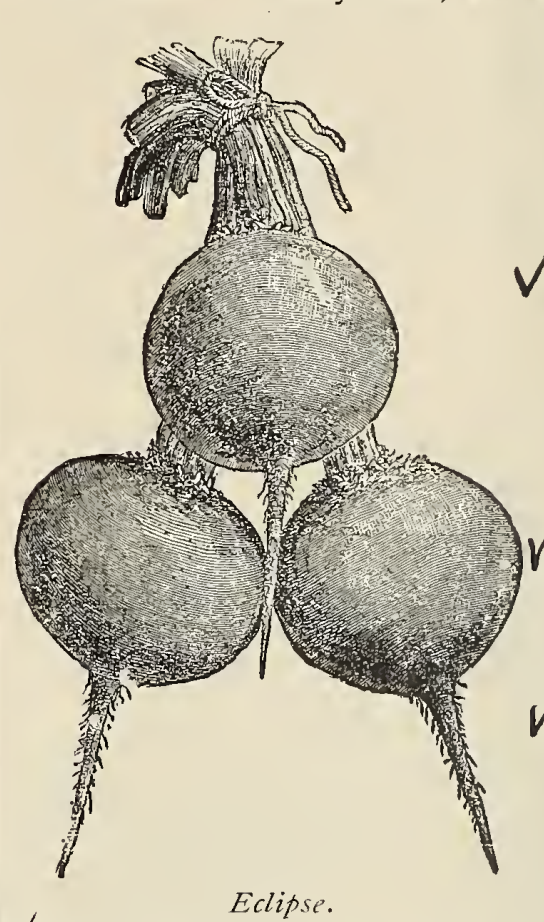
ground will adinit, in drills fourteen inches apart, and thin to four inches $\mathrm{d}$ istant. For winter, so w about the middle of spring.

D a r k e d Egy ptian. The earliest beet in cultivation; flat, very deep red, small tops. Price per pkt., 5c.; per oz., Ioc.; per 1b.,

\section{$40 c$.}

Crimson Globe. (See Novelties, page 2). Price per pkt., 5c. ; per oz., ${ }^{5} \mathrm{c}$. per 1b., 8oc.

Crosby's Egyptian. An inproved strain of the Eigyptian beet. Is much thicker and smoother, about as early.

$\checkmark$ Price per pkt., $5 \mathrm{c}$.; per oz., Ioc.; per 1b., $50 \mathrm{c}$.

Dirigo, (See Novelties, page 3.) Price per pkt., 5c.; peroz., Ioc.; per 1b., 6oc.

Detroit Dark Red Tops smal1; roots ovoid; peculiarly smooth; color of skin dark blood red, flesh bright red. Price per pkt., 5 .; per oz., roc.; per lb., $40 \mathrm{c}$.

Celipse. Very early; dark red flesh and skin, small

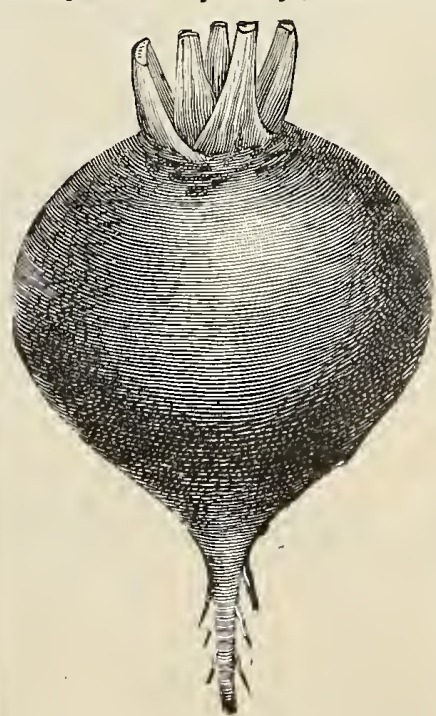

Dewing's Early Blood Turnip. tops, almost spherical in form. Price per pkt., 5c.; per gz., IOc.; perlb., 3Oc. Edmand's E a r 1 y Blood Turnip. Deep blood skin, and very dark flesh of best quality. Price per pkt., 5c.; per óz., yoc; per 1b., 4oc.

Bastian's Early Blood Turnip. Dark red, early and good shape; flesh circled with lighter color. Price per pkt., 5c.; per oz., Ioc.; per 1b., $40 \mathrm{c}$.

Early Bassano. Flesh circled with bright red, grows to a large size. Price per pkt., 5c., per oz., Ioc.; per 1b., 3oc. 


\section{BEETS-continued.}

LEarly Blood Turnip. A standard early, dark red, round variety. Price per pkt., 5c.; per oz., Ioc.; per $1 \mathrm{~b}$, , 3oc.

Bewing's Early Blood Turnip. Deep blood red, free Arom fibrous roots. Price per pkt., 5c.; per oz., Ioc.; per $1 \mathrm{~b} ., 40 \mathrm{oc}$.

Early Yellow Turnip. Flesh yellow, tender and sweet. Price per pkt., $5 \mathrm{c}$.; per oz., IOc.; per 1b., 5oc.

Long Smooth Blood. Au excellent late variety and good for winter use; swooth skiu, flesh dark red. Price per pkt., 5c.; per oz., Ioc.; per 1b., $40 \mathrm{c}$.

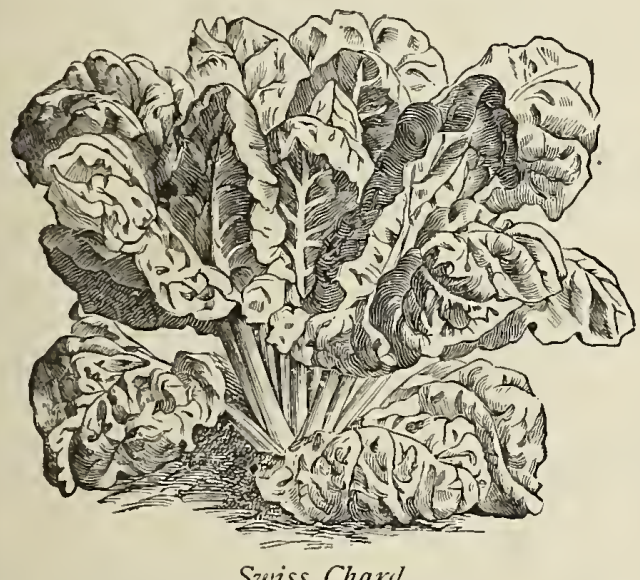

Swiss Chard.

Swiss Chard or Silver. This variety is cultivated for its leaves. The mid rib is boiled and served like asparagus, and the other portions of the leaves are used as spiuach. When wanted, cut close down to the ground, and new leaves will grow. Price per pkt., 5c.; per oz., loc.; per 1b., 5oc.

\section{BEETS-Mangel Wurtzel.}

\section{LARGELY GROWN FOR FEEDING STOCK.}

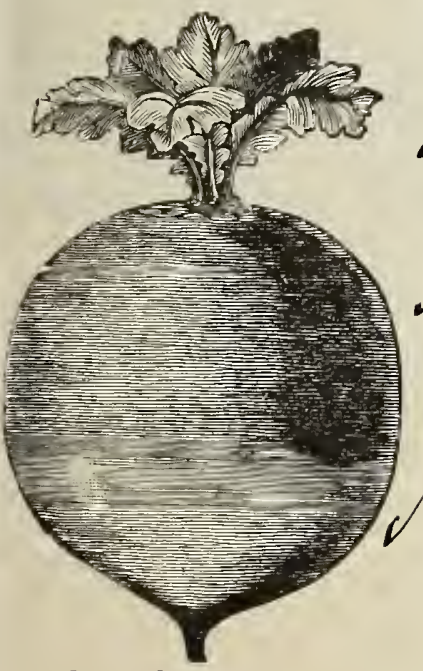

Red Globe. A large, round, red skinned variety, aud good keeper. Iu lots of Io 1bs., I5e.; per oz, 5c.; per ho., $20 \mathrm{c}$.

Orange Yellow Globe. Grows smooth; free from small roots. Large size and good color. I/1 lots of Io lbs., I5c. per oz., 5c.; per 1b., 20c. GoIden Giant Interme. diate. A very large yellow sort, with rus set skin and light, yellow - colored flesh. In lots of io lbs, 20c; per oz., 5c.; per 1b., $25 \mathrm{c}$.

Golden Tankard. Half long, nearly uniform diameter from top to bottom ; good quality. In lots of Io 1bs., 2oc; Orange? Yellow Clobe.
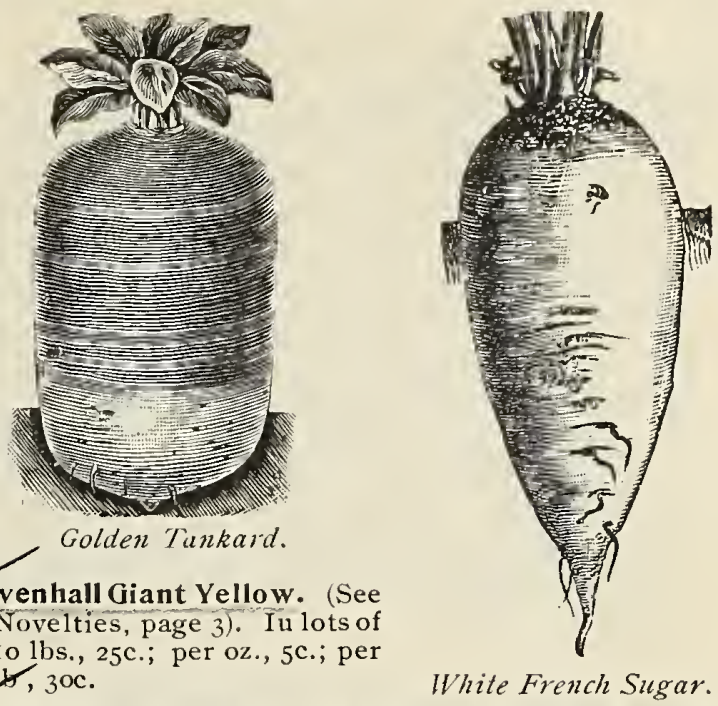

White French Sugar.

White French Sugar. Tlis attains a large size, and is exteusively grown for feeding, though employed largely in the manufacture of beet sugar. In lots of to lbs., 15c.; per oz., 5c; per lb: 20c.

Mammoth Long Red. Grows to an enormous size, and acknowledged the most desirable of its class. In lots of In 1hs., 25c.; per oz., 5c; per lb., 3oc.

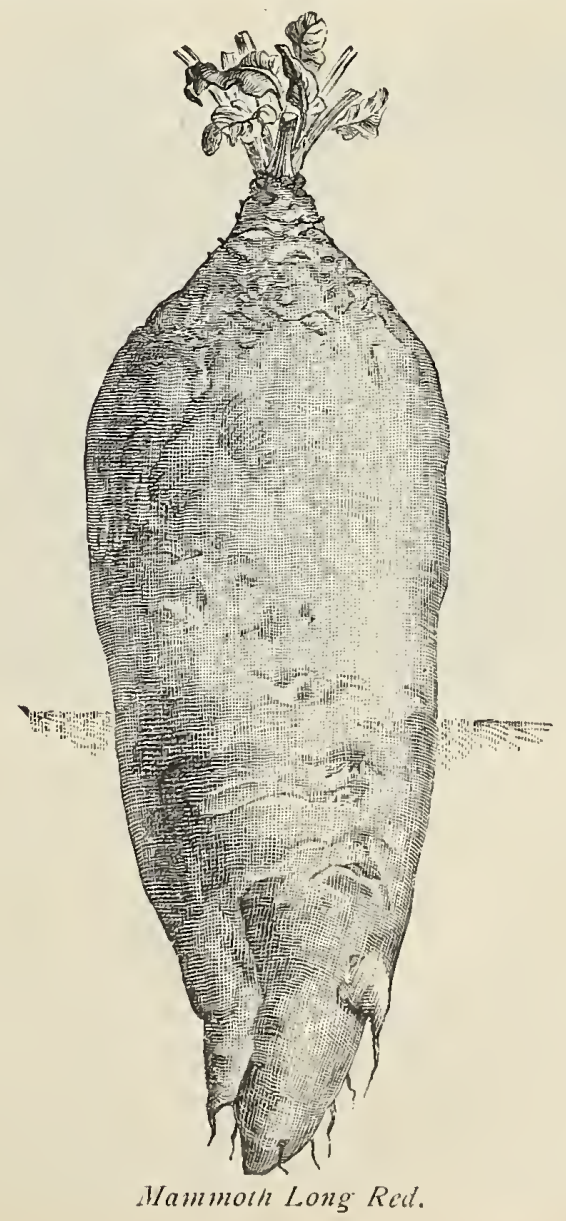




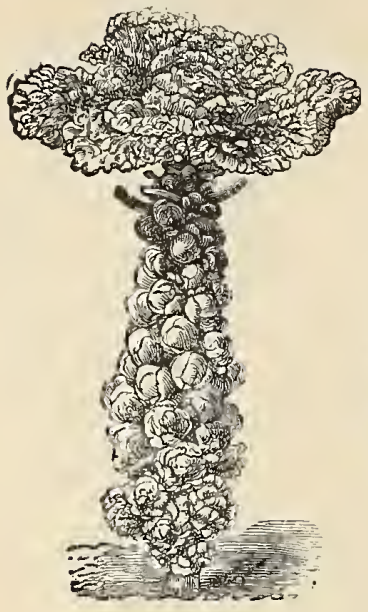

Brussels Sprouts.

\section{BEETS-Continued.}

Lane's Improved Imperial Sugar. This was obtained through successive careful selections from the French Sugar Beet. In lots of Iolbs., 20:.; per oz., 5c.; per lb., $25 \mathrm{c}$.

\section{BROCGOLI.}

\section{Spargel Kohl-Broculi-Broccoli.}

Broccoli is a variety of cabbage nearly allied to cauliflower; succeeds only under cool, damp conditions. Sow thinly in seed beds about the middle of spring, transplant and cultivate according to directions for winter cabbages. The plants in seed beds are very apt to run up tall and slender, unless they are thinned and kept free from weeds.

Early White Cape. The heads when full grown are large, white and compact, and one of the niost certain to head. Price per pkt., Ioc.; per oz., 4oc.

Early Purple Cape. Differs from the white in color only. Price per pkt., Ioc.; per oz., 40c.

\section{BRUSSELS SPROUTS.}

\section{Sprossen Kohl-Berza de Brusels-Broccolo di Carolo.}

A very desirable vegetable. The plant grows to two'or three feet high, and produces from the sides of the stalk numerous little sprouts one or two inches in diameter, resembling cabbages. The leaves look like the Savoy, and should be broken down in the fall, to give the little cabbages more room to grow. They are used for fall and winter greens, are quite hardy, and should be treated in all respects like winter cabbage or kale.

Dalkeith. Dwarf, compact, producing larger sprouts than the older varieties. Price per pkt., 5 c.; per oz., 2oc.; per 1b., \$2.0o.

\section{CABBAGE.}

Kopf Kohl-Berza de Repollo-Cappuccie.

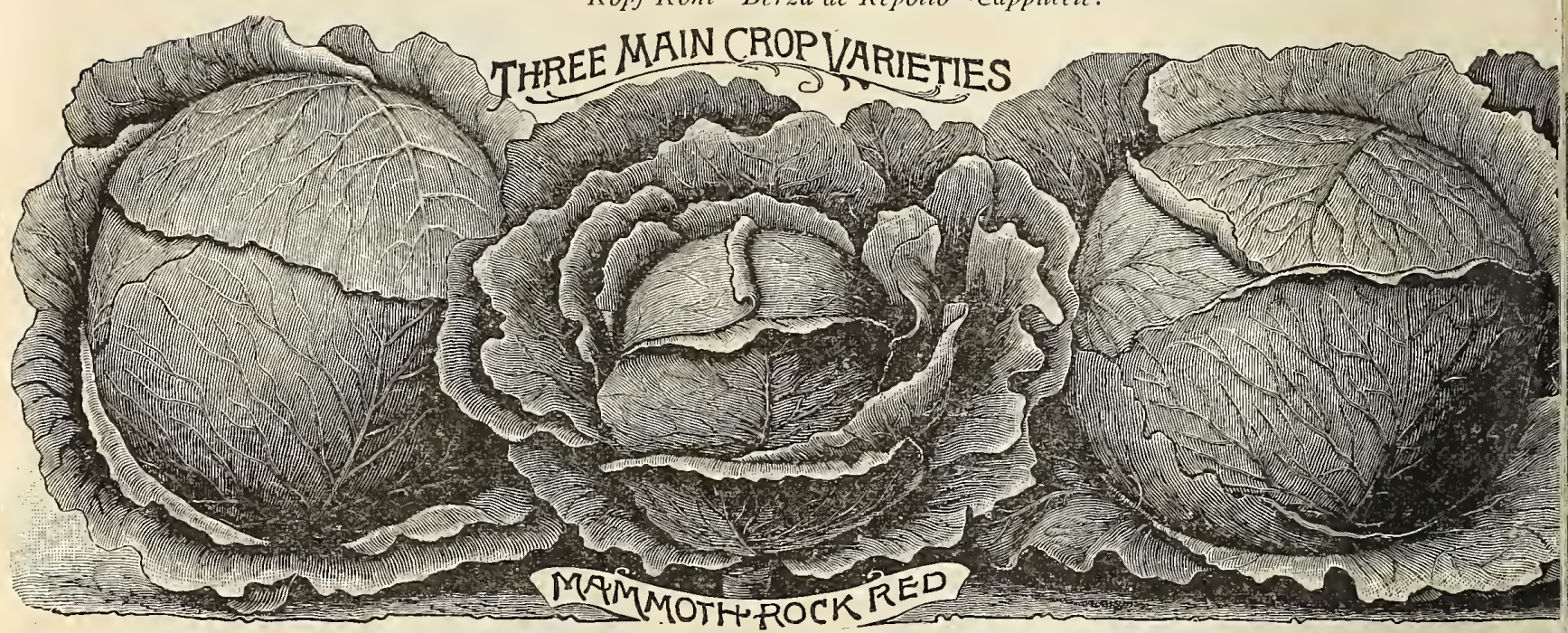

Surehead.
Succession.

The cabbage requires a deep, rich soil and thorough working. For early use the plants should be started in a hotbed or cold frame; but seed for winter cabbage should be sown in a seed bed early in the spring. Some of the large late varieties seem to do best if the seed is sown in the hills where they are to remain, and in that case sow two or three seeds where each plant is desired, and then pull up all but the strongest. Plant the large varieties three feet apart; the small, early sorts, from a foot to eighteen inches. The Savoy cabbages have wrinkıed leaves, and are of fine flavor, especially after a little frost has touched them in the autumn.

Early York. One of the earliest ; cone-shaped variety. Price per pkt., 5c.; per oz., I5c.; per 1b., \$I.25.

Early Winningstadt. Heads good sized, cone-sliaped and solid. Price per pkt., 5c; per oz., I5c.; per $1 \mathrm{~b}$., $\$ \mathrm{r} .25$. Charleston or Large Wakefield. Similar to Early Jersey Wakefield, but larger and a little later. Price per pkt., 5c.; per oz., 3oc.; per lb., \$3.00.

All Seasons or Vandergaw The heads of this cabbage are large and thick through; an excellent variety for early or fall marketing. Price per pkt., 5c.; per oz., 2oc.; per $1 \mathrm{~b} ., \$ 2.00$.

Early Flat Dutch. Medium early, fair size, flat head. Price per pkt., 5c.; per oz, 20c.; per 1b., \$2.uo.

All Head. It is a large, flat, early summer variety of fine quality. Price per pkt., 5 c.; per oz., $20 c . ;$ per 1 b., $\$ 2.00$. Early Summer. Medium early, good size, of the Drumhead order. Price per pkt , 5c ; per oz , 25c.; per $1 \mathrm{~b} ., \$ 2.50$. Surehead. Very firm, large flattened heads. Price per pkt., 5c.; per oz., 2oc.; per 1b., \$2.oo. 


\section{CABBAGE-Continued.}

Early Jersey Wakefield. Heads very solid, pyramidal, blunted at the top. Price per pkt., 5 c.; per oz., 25c.; per 1b., \$2.50.

Succession. The cabbage is about one week later than the Early Suuimer, but is double the size. Price per pkt., 5c.; per oz., $25 \mathrm{c}$; per lb., $\$ 2.50$.

Fottler's Improved Brunswick. This is a sbort stem, early, large heading Drumhead variety. Price per pkt., 5c; per oz., 2oc.; per $1 \mathrm{~b}$., $\$ 2.00$.

The Lupton Cabbage. It is a medium late Drumbead variety, coming in after the second earlies and before the late. Price per pkt., $5 \mathrm{c}$.; per oz., 20c.; per 1b., \$2.00.

Danish Ball Head. (Fine Danish-grown seed.) The round, hard-headed cabbage, imported late every winter and prized for its solidity. size of head and keeping qualities. Price per pkt., 5c.; per oz., 20c.; per 1b., \$2.00.

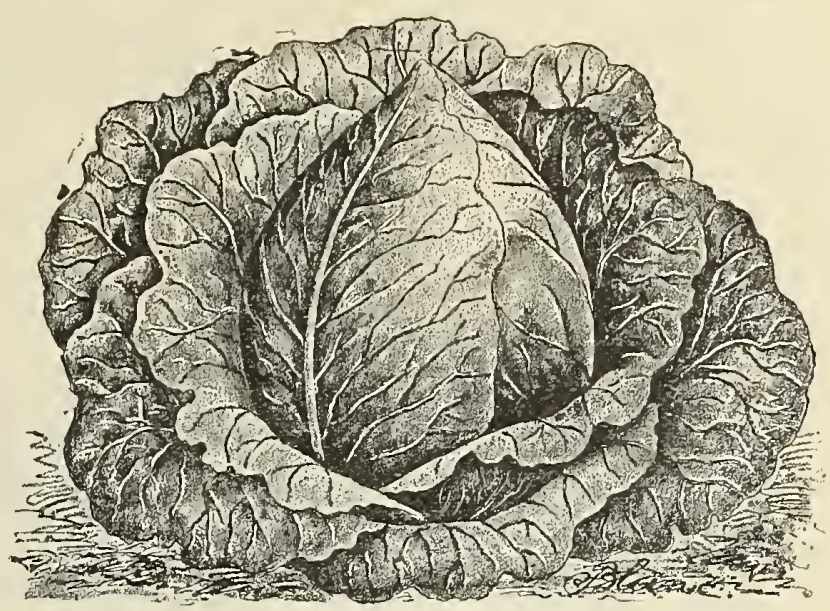

Perfection Drumhead Savoy. Very tender and excel. lent for winter use; the largest heading sort of its kind Price per pkt., 5c.; per oz., 20c.; per 1b., \$2.oo.

Mammoth Red Rock. This is a very fine strain of Red Drumhead. Heads large, round and thick, very dark from surface to center. Price per pkt., 5c.; per oz., 25c.; per lb., \$2.50.

Premium Flat Dutch. A variety for the winter; heads large, solid, broad and flat on the top; they open white and crisp. Price per pkt , 5c.; per oz., I5c.; per 1 b., $\$$ I. 50 .

Large American Drumhead. Grows to a large size, with compact heads. Price per pkt., 5c.; per oz, 2oc.; per lb., \$2.00.

Stone Mason Drumhead. Head flat and solid, stem short and small. Price per pkt., 5c.; per oz., 25c.; per 1 b., $\$ 2.50$.

Mammoth Marblehead Drumhead. A late variety; the largest growu. Price per pkt., $5 \mathrm{c}$.; per oz., $25 \mathrm{c}$.; per 1b., $\$ 2.50$.

\section{GARROTS.}

Mochre-Zanahoria-Carote.

The carrot, like other root crops, delights in a sandy loam, deeply tilled. For early crops sow in the spring, as soon as the ground is in good working

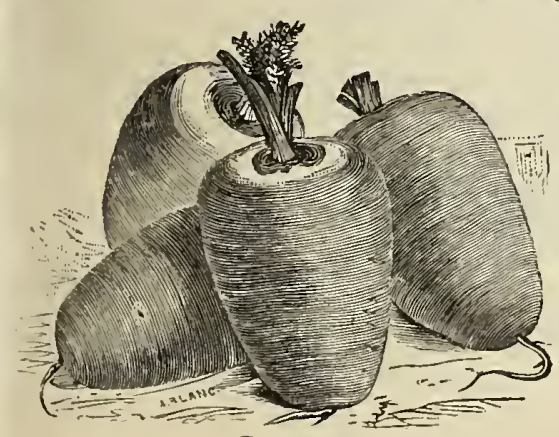

Guerande or Oxhearl. order; for 1 a te crops they may be sow n ally time until the middle of $\mathrm{J} u \mathrm{n}$ e. Sow in rows about fifteen inchesapart, thinning out to three or four inches between the plants.

Early, French Forcing. Small oval in shape; the bes forcing variety. Price per pkt., 5c.; per oz., Ioc.; per 1 h., $60 \mathrm{c}$.

Early Scarlet Horn. An early suninier variety, excellent for table use; color, deep orange. Price per pkt., 5c.; per oz., toc.; per 1b., 6oc.

Early Jersey Wakefield.

\section{CARROTS-continued.}

Early Malf=Long Scarlet Carentan. Stump-ending. The skiu is smooth, flesh red and without core or heart. It is excellent for forcing, fine quality and perfect shape. Price per pkt., 5c.; per oz., IOc.; per 1b., 6oc.

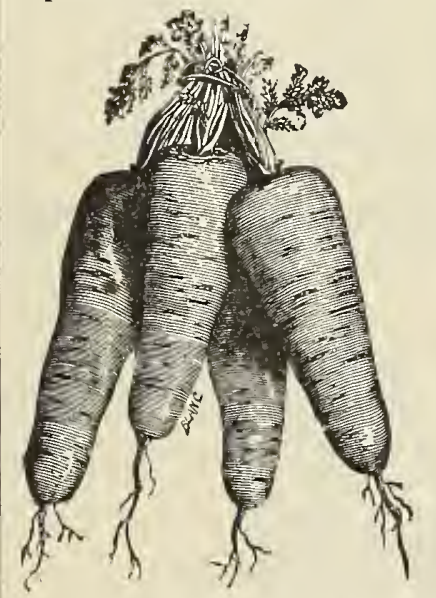

Chantenay $\mathbf{H}$ a I f . Long Scarlet. A stump-eud variety of good quality, large sliouldered and very productive. Price per pkt., 5c.; per oz, Ioc.; per lb., 6 oc.

Guerande or $\mathbf{0 x}-$ heart. Very large at the top, in proportion to its length, holding its size well for three to five inches, and terminating abruptly. Price per pkt., 5c.; per per oz., Ioc.; per lb., 6oc.

Improved Danvers. Half-Long Scarlet Carentan. Grows quite large, medium in length; stump-end, bright orange color and a good cropper. Price per pkt., 5c.; per oz., Ioc.; per lb., 6oc.

Long Orange Improved. Roots of large size and adapted to garden or field culture. A profitable variety for stock feeding. Price per pkt, 5c.; per oz., Ioc.; per lb., 5oc.

White Giant, Green Top. Used for feeding horses and stock. Price per pkt., 5c.; per oz., roc ; per 1b., 5oc.

\section{CARDOON.}

\section{Kardon-Cardo-Cardone.}

Cardoon is grown for the mid-rib of the leaf, and requires to be blanched in the same manner as celery. Sow early in the spring, where the plants are to remain, in drills about three feet apart, an incli and a half deep, and thin out the young plants to a foot apart in drills.

Large Spanish. Price per pkt., loc; per oz., foc. 


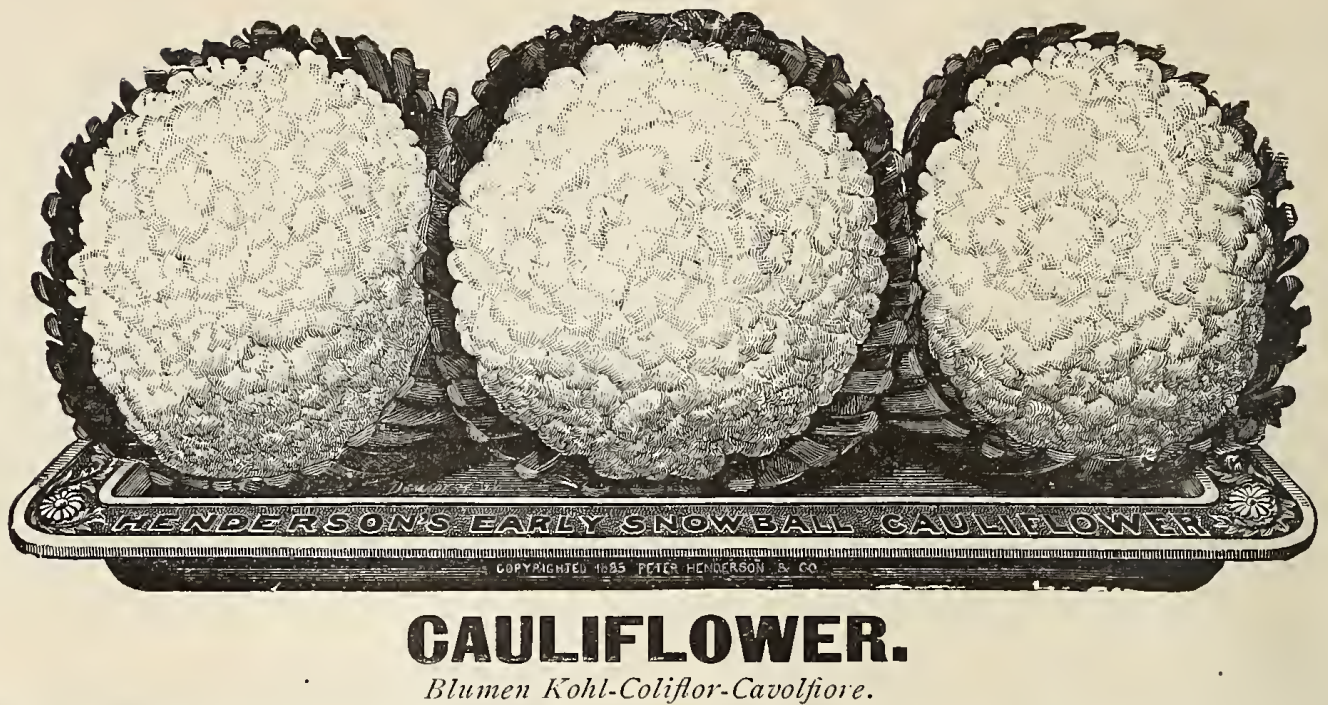

Should be sown according to instructions for cabbage, manuring liberally and cultivating thoroughly. It will thrive best in cool, moist situations.

Early Snowball. Very reliable for heading, besides being very dwarf in growth, with short outside leaves. Price per pkt., 2oc.; per oz.. \$2.00; per 1b., \$24.0o.

Improved Early Paris. A standard early variety. Price per pkt., 1oc.; per oz., 7oc.; per $1 \mathrm{~b}$. $\$ 7.00$.

Extra Early Dwarf Erfurt. Good for forcing. Very dwarf, pure white 1eads, good quality. Price per pkt., Ioc.; per oz., \$I.75; per 1b., \$I8.oo.

Early London. A large medium variety. Price per pkt,, 5c.; per oz., 5oc.; per lb., \$5.oo.

Autumn Late Giant. A valuable late variety, producing large white, firm heads. Price per pkt., Ioc,; per oz. 6oc.; per 1b., \$6.oo.

LeNormand's Short Stem Mammoth. The largest and one of the most reliable for general cultivation. Price per pkt., Ioc.; per oz., 75c.; per lb., $\$ 7.50$.

\section{GELERIAC OR TURNIP-ROOTED CELERY.}

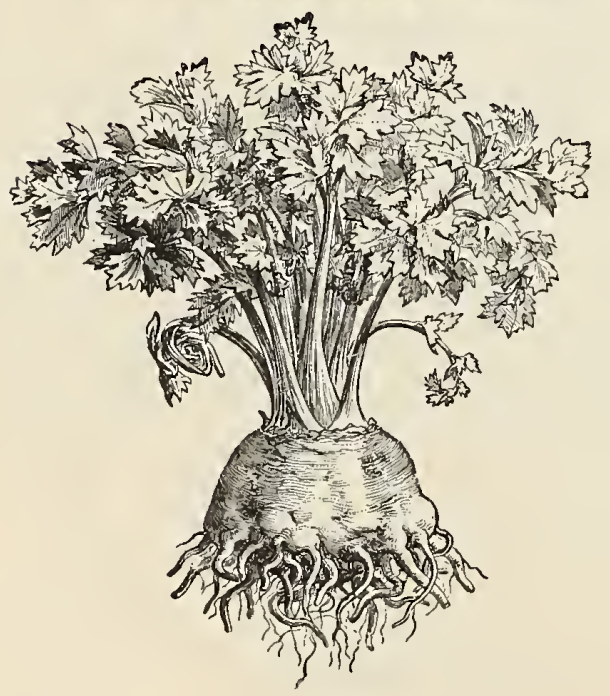

Celeria.

A variety of celery, having turnip-shaped roots which may be cooked or sliced and used with vinegar, making a most excellent salad. It is more hardy, and may be treated in the same manner as celery.

Turnip-Rooted. Turnip-shaped, sweet and well-flavored. Price per pkt., $5 \mathrm{c}$.; per oz., $x_{5} \mathrm{c}$; per $1 \mathrm{~b}$., $\$ \mathrm{I} .5 \mathrm{o}$.

Large Prague. Nearly round, smooth and good quality. Price per pkt., 5 c., per oz., 2oc.; per lb., $\$$ I.75.

\section{GHERVIL. \\ Gartenkerbel-Perifollo-Certaglio.}

Cultivated like parsley. The young leaves are used for flavoring. For summer use sow in March, and in July for winter.

Curled. Price per pkt., 5c.; per oz., I5c.; per 1b., \$I.50.

\section{GHICORY.}

\section{Cichorien-Cicorea.}

The roots of this vegetable are much used as a substitute for coffee.

Large Rooted or Coffee. Price per pkt., 5 c.; per oz., Ioc.; per lb., 8oc.

\section{CELERY.}

Seleri-Apios-Sedani o Acci.

Sow seeds in hotbed or very early in open ground (it is slow to germinate, and sbould be kept very moist.) Sow in straight rows for convenience in weeding when plants are very small. When two or three inches high thin out or transplant to three inches apart. Celery requires very rich soil and plenty of water. Plants may be set from May to the middle of August. The large growers plant most of the crop upon the surface, having previously plowed in all the manure possible, and setting in rows two to four feet apart and six inches in the row. 


\section{GELERY-Continued.}

Giant Pascal. Large, thick and solid stalks, dark green foliage and golden heart. Price per pkt., 5c.; per oz., $20 \mathrm{c}$; per 1b., \$I.5O.

Golden Self=Blanching. The ribs are perfectly solid, crisp and brittle, and of delicious flavor. Price per pkt., 5c.; per oz., 25 c.; per 1b., $\$ 2.50$.

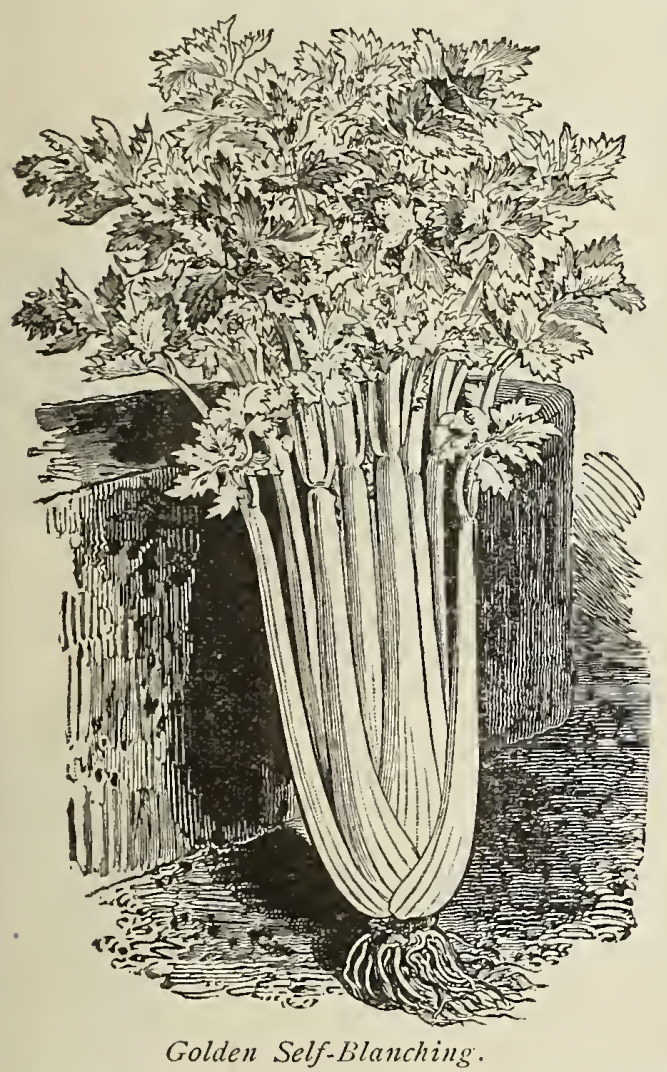

Perfection Hartwell. A vigorous and stocky growing kind, with large and compact heart of pure golden color; good late variety. Price per pkt., 5c.; per oz., 20c.; per 1b., \$I.75.

Kalamazoo Broadribbed. Cream-white color throughout, attains a very large size, of quick growth, stiff and close habit, very solid. Price per pkt., 5c.; per oz., 20c.; per 1b., \$2.0o.

White Plume. This is very early; its stalks, inner leaves and heart blanching naturally to a cream white. Price per pkt., 5c.; per oz., 2oc.; per 1b., $\$ 2.00$.

Pink Plume. A strong, compact grower; stems solid and crisp; extra early and a long keeper. Price per pkt., 5 c; peroz., 25c; per lb., \$2.50.

Golden=Hearted Half Dwarf. Centerstalks and leaves blanching a rich yellow, solid, good cropper and keeper. Price per pkt., 5c.; per oz., 2oc.; per 1b., $\$ \mathrm{I} .50$.

Crawford's Half Dwarf. A very popular variety, grows to a good size. Price per pkt., 5c.; per oz., 20c.; per 1b., \$I.50.

Schumacher. Yellow center, solid and crisp. A late variety and good keeper. Price per pkt., 5c.; per oz., 30c.; per 1b., \$3.0o.
Giant White Solid. One of the old standard sorts and a very large variety. Price per pkt., 5c.; per oz., 2oc.; per lb., \$1.50.

Boston Market. Short, compact and solid, and keeps well through the winter. Price per pkt., 5c.; per oz., 2oc.; per 1b., \$1.50.

New Rose. This is very ornamental, the delicate tracing of rose shading with the white in the blanched stalks and heart. Very solid, rich, and nutty in flavor; keeps well. Price per pkt., 5c.; per oz., 25c.; per 1b., $\$ 2.50$.

Celery Seed. For flavoring. Old seed. Price per oz., 5c.; per 1b., $40 \mathrm{oc}$.

\section{GHIVES.}

Schnittlauch-Cipollette.

Chives are perfectly hardy little perennial members of the onion tribe and are grown exclusively for their tops, which are used whenever the flavor of onion

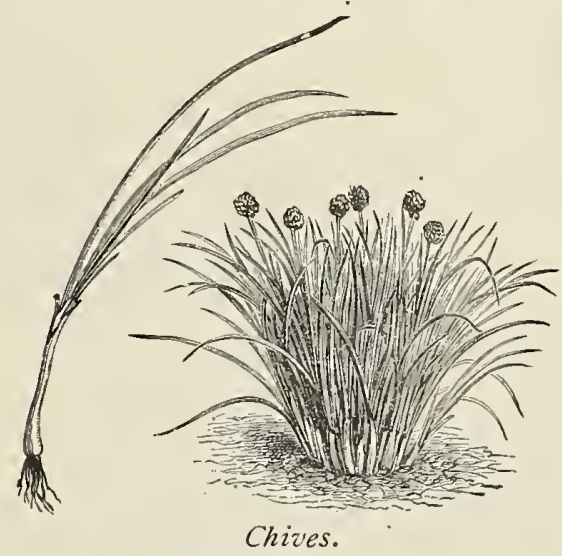

is required. Planted in small clumps in any common garden soil, they will grow rapidly, and in time increase so as to render a division necessary. The tops appear very early in spring, and can be cut throughout the season. Roots, perbunch, roc.

\section{GHUFAS.OR}
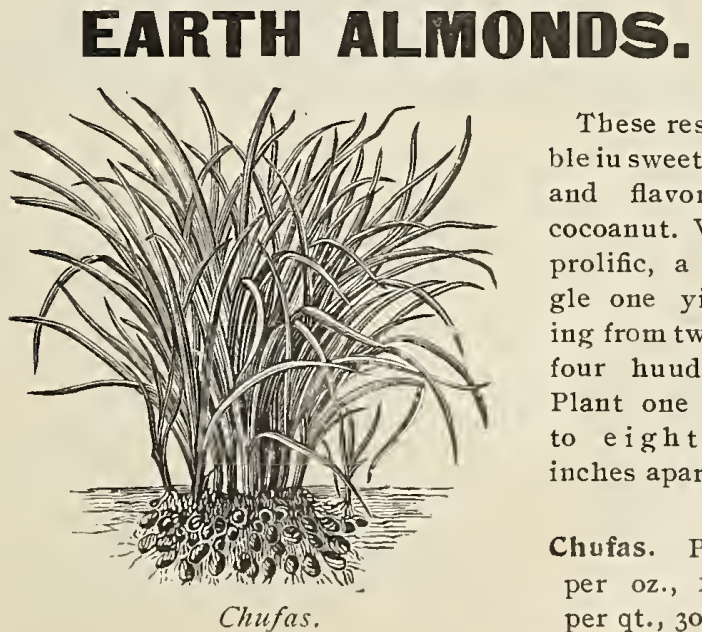

These resemble iu sweetness and flavor a cocoanut. Very prolific, a single one yielding from two to four huudred. Plant one foot to eighteen inches apart.

Chufas. Price per oz., IOc.; per qt., 3oc, 


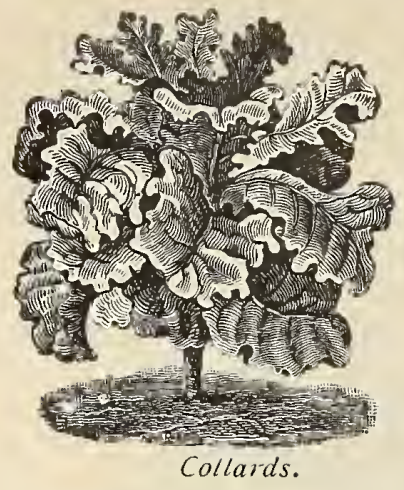

\section{COLLARDS OR GOLEWORTS.}

\author{
Biätterkohl-Cabu-Cavoli.
}

A class of plants closely allied to the cabbage family, which are used in the South, when small, as greens. Sow in early spring in drills one foot apart. The young plants are ready for use as soon as they have attained sufficient size, but if it is desired to keep them in good condition, thin the plants to six or eight inches a part and pull off the larger leaves before using.

True Southern. Per pkt., 5c.; per oz., I5c.; per !b., \$1.oo.

\section{CORN FOR POPPING.}

Granone per Scoppio.

Nonpareil White. Eight.rowed. Long ears, pops very large. Price per dozen ears, $25 \mathrm{c}$.; perqt., shelled, 40c.

Silver Laced. Small kernel, twelve to sixteen-rowed. Price per dozen ears, 25c.; per qt., shelled, $40 \mathrm{c}$.

White Rice. Sharp-pointed kernels, twelve to sixteen-rowed. Price per dozen ears, 25c.; per qt., shelled, 4oc.

Red Rice. Sharp-pointed kernels, twelve to sixteen-rowed. Price per doz. ears, 25c.; per qt., shelled, 5 oc.

Queen's Golden Pop. The ears large, twelve to sixteen-rowed, bright yellow. Price per doz. ears, 35c.; per qt., shelled, 5oc.

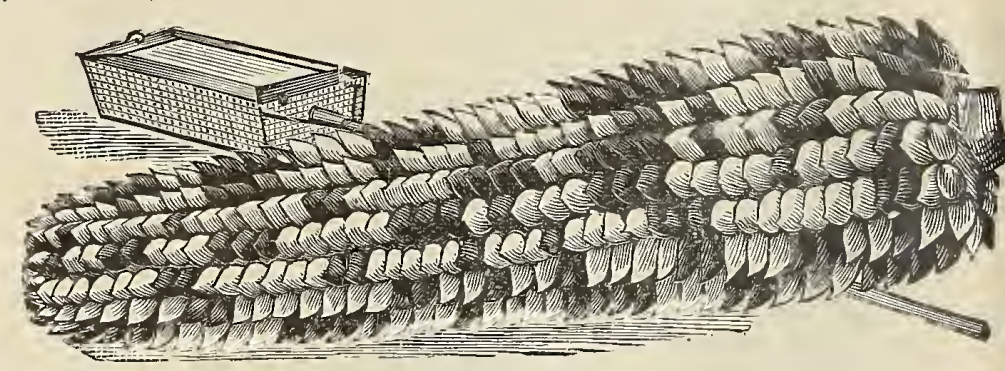

\section{CORN--Varieties for Field Culture.}

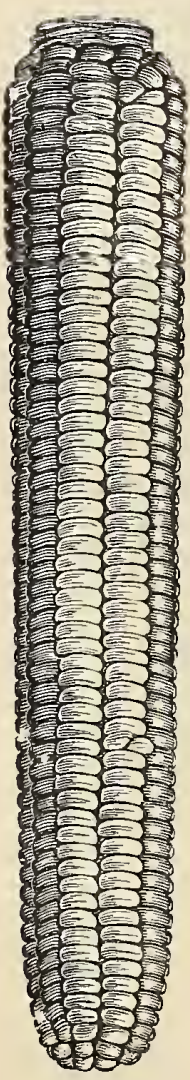

Improved Sanford.
Granone o Grano-turco.

Early Mastodon. Very early, large eared, and large dented kernel. Price per I0o ears, $\$ 2.00$; per qt., I2c.; per bu., $\$ \mathbf{I} .50$.

Golden Dew Drop. It is an early yellow, eight-rowed flint variety. Grains of good size, small white cob. Price per Ioo ears, $\$ 1.50$; per qt., I2c.; per bu., \$I.50.

Early Eight=Rowed Yellow Canada. The earliest corn, a yellow glazed or flint variety, eight-rowed and cob small; produces two or three ears to the stalk, and grows from four to five feet high. Price per Ioo ears, $\$ 1.50$; per qt., I2c.; per bu., \$I.50.

Compton's Early. A very early and prolific yellow flint variety, twelve to sixteen-rowed, small kernel and rather large cob. Price per Ioo ears, $\$ 2.00$; per qt., I2c.; per bu., \$I.50.

Longfellow. The ears are remarkably long, cob small, kernels large, eight-rowed yellow flint. Price per Ioo ears, $\$ 2.00$; per qt., I $2 c$; per bu., $\$ \mathrm{I} \cdot 5 \mathrm{O}$.

Improved Sanford. A large white flint sort; ears large and very productive. This variety is used largely for ensilage or fodder corn. Price per I00 ears, $\$ 2.00$; per qt., I 2c.; per bu., $\$ 1.50$.

Large Yellow Flint. Similar to the preceding, except in color. Price per IOo ears, $\$ 2.00$; per qt., I 2c.; per bu., $\$ \mathrm{I} .50$.

Queen of the Prairie or Pride of the North. This is an early Yellow Dent variety. It will mature in ninety days. Price per Ioo ears, $\$$ I.50; per qt., I 2c.; per bu., \$I.50.

Leaming. The ears are lar;e, with deep, large dented grain; orangeyellow color and small red cob. Price per Ioo ears, $\$ 2.00$; per qt., I2c.; per bu., $\$ \mathbf{I} \cdot 5$ O.

Golden Beauty (Dent). A very productive varietv; fourteen to sixteenrowed; very large kernel. Price per Ioo ears, $\$ 2.00 ;$ per qt., I2c.; per bu., \$I.5O.

Hickory King. Extremely large grain and small cob; white Dent. Price per Ioo ears, $\$ 3.00$; per qt., I5c.; per bu., $\$ I$. 75 .

Southern White Fodder. A white Dent corn, bearing a medium sized ear, with very deep kernels on small cob. It is generally grown for its stalk and foliage, which attain a height of fourteen to eighteen feet. Used extensively as an ensilage or fodder crop. Price per bu., $85 \mathrm{c}$.

Red Cob Ensilage. A white corn on red cob. Stalks short-jointed and very tall, with heavy foliage. One of the best for ensilage. Price per bu., $\$$ I.oo. 


\title{
Sweet Gorn.
}

\author{
Zucker Maiz-Naiz \\ -Granone dolce.
}

\section{EXTRA EARLY VARIETIES.}

Extra Early Adams or Burling. ton. While not a sugar corn, this is a tender, white variety for table use. Dwarf stalk, small ears; very hardy, can be planted earlier than any sweet corn; matures within sixty days. Price per ear, 4c.; per qt., I5c.; perbu., $\$ 2.25$.

Burbank Early Maine. Extra early, pure white, kernel and cob; good sized ear. Per ear, 4c.; perqt., 20c.; per bu., $\$ 3.00$.

Cory. Very early. Ears good size and quality excellent; color of both corn and coblight red when dry. Per ear, 4c.; per ct., 20c.; per bu., $\$ 3.00$.

White Cory. Very early, good sized, both corn and cob white. Per ear, 5c.; per qt., $25 \mathrm{c}$; per bu., $\$ 3.00$.

Metropolitan. (See Novelties, Page 3.) Per ear, 5 c.; per qt., 30c.; per pk., $\$ 1.50 ;$ per bu., $\$ 5.00$.

Farly Minnesota. Very early, white, sweet and good flavor, ears of fair size and marketable. Price per ear, 4c.; per qt., 20c.; per bu., \$3.0o.

Crosby's Extra Early. An early kind; very sweet and sugary, grows ten to twenty rows on an ear. Price per ear, 4c.; per qt., $20 \mathrm{c}$.; per bu., $\$ 3.00$.

Champion. (See Novelties, page 4.) This is the largest of our early varieties. It is ten and twelve rows, very fine in quality and follows closely the extra earlies. Price per ear, 4c.; per qt., 20c.; per bu., $\$ 3.00$.
Early Golden Yellow. Average quality, good size ears. Tle seed when dry is a beautiful golden color. Price per ear, 5c.; per qt., 20c.; per bu., $\$ 3.00$.

Potter's Excelsior or Squantum. Medium early. Large ears of excellent quality. Very productive. Price per ear, 4c.; per qt., 20c.; per bu., $\$ 2.75$.

Mexican Sugar. Very sweet, but objectionable on account of its color, which is black. Price per ear, 4c.; per qt., 20c.; per bu., \$3.0o.

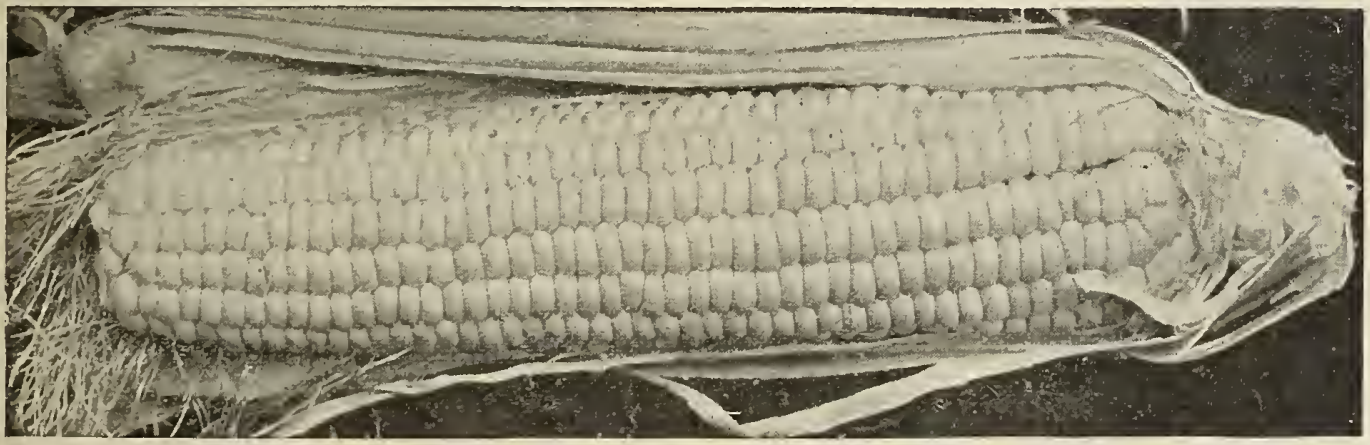

Champion.

\section{Medium Varieties.}

Perry's Hybrid. Grows about six feet high. Ears twelve-rowed, sometimes fourteen. The $\operatorname{corn}$ is white and the cob light red. Price per ear, 4c.; per qt., 20c.; per bu., $\$ 2.75$.

Stabler's Early. Large ears, twelve to fourteen rows, well rounded with very sweet, pure white kernels. Price per ear, 4c.; per qt., 20c.; per bu., $\$ 2.75$.

Pee and Kay. Medium size ears; kernels white and sweet; ears are ten to twelve-rowed. Price per ear, 4c.; per qt., 20c.; per bu., $\$ 2.75$.

Moore's Early Concord. Ears large, with twelve to sixteen rows, and of superior quality. Price per ear, 4 c.; per qt., 20c.; per bu., $\$ 2.75$.

\section{LATE VARIETIES.}

Hickox Improved. A large-eared, medium-late variety of great merit. Price per ear, 4c; per qt, 20c.; per bu., $\$ 2.75$.

Stowell's Evergreen. A large variety and standard sort for family or market use. Price per ear, 4c.; per qt., 20c.; per bu., $\$ 2.50$.

Roslyn Hybrid. Of the early mamnoth type, but rounding out full at the tip. Price per ear, 5c.; per qt., 2oc.; per bu., $\$ 2.75$.

Egyptian. The ear is large size, flavor peculiarly rich and sweet. Price per ear, 5c.; per qt., 20c.; per bu., $\$ 2.75$. 


\section{Sweet Copn-Continued.}

\section{LATE VARIETIES.}

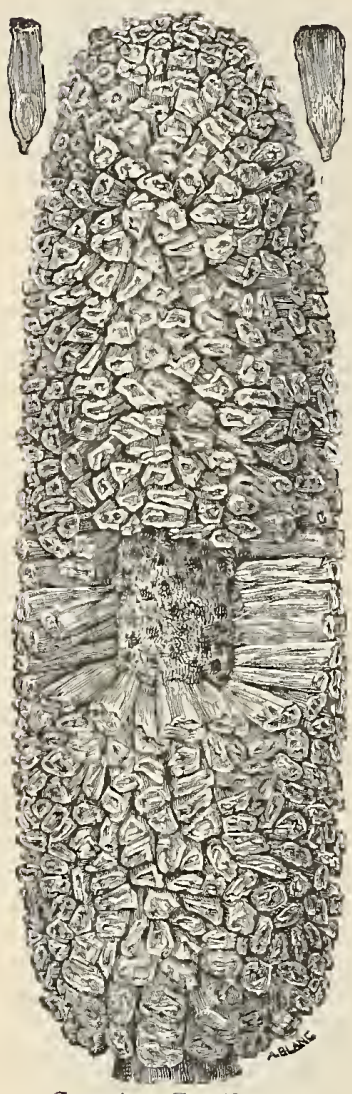

Country Gentleman. bu., $\$ 3.00$. per bu., $\$ 2.75$. per bu., $\$ 2.75$.
Country Gentleman, $\mathrm{Ne}$ Plus Ultra, Shoe Peg, Little Gem or Quaker Sweet (all one). It is a medium late variety, medium sized ears of delicate, sweet and fine flavored corn, Price per ear, 5c.; per qt., 20c.; per

Early Mammoth. Sometimes called Marblehead Early Mammoth. Similar in all respects to the large Late Mammoth, except in time of matur. ing, which is ten days to two weeks earlier. Price per ear, 5c ; per qt., 20c.;

Late Mammoth. The largest and latest variety, growing from sixteen to twenty rows on an ear; quality excellent. Price per ear, 5c.; per qt., 20c.;

Sweet-Corn-for-Fodder. The sweet corn is decided. ly preferable to the yellow or field varieties for this purpose, the stalks being fine grained and better supplied with saccharine matter. Price per bu., $\$ 1.00$.

\section{Corn Salad or Fetticus.}

\section{Ackersalat-Macha o Vaterianilla-Valerianelta o} Insalata.
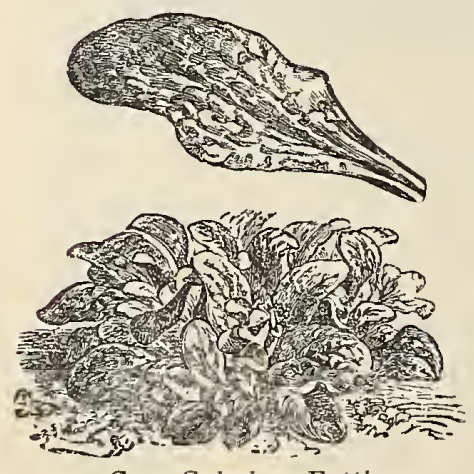

Corn Salad or Fetticus.

Large Leaved. Per pkt., 5c.; per oz., Ioc.; per 1b., 5oc.
A vegetable used opening of spring. in rows one foot apart, and is fit for use in six or eight weeks from the time of sowing. If wanted to come up in early spring, it is sown in Septem. ber and covered u] with straw or has as soon as cold weather sets in, and is wintered over the same as spinach. as a salad. It is
Gress or Pepper Grass.

Kresse-Berro o Mastuerzo-Crescione.

Extensively used as a small salad. Sow early in the spring, very thickly in shallow drills. The sowing should be repeated at intervals, as it soon runs to seed.

One ounce of seed will sow a

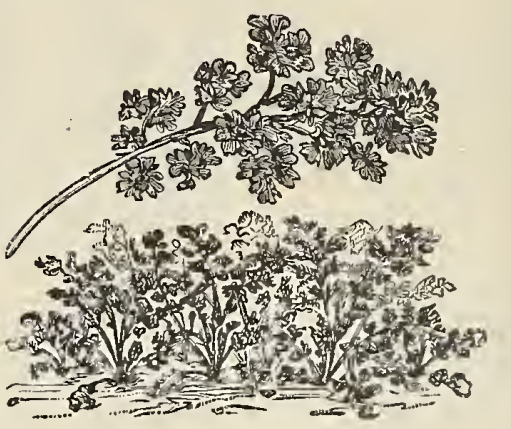

Cress or Pepper Grass. bed of sixteen square feet.

Extra Curled. Fine curly leaved, pungent and refreshing. Price per .pkt., 5c.; per oz., IOc.; per 1b., 40c.

Upland. Resembles the water cress in taste; s a m e culture as spinach, a perennial plant. Per pkt., Ioc.

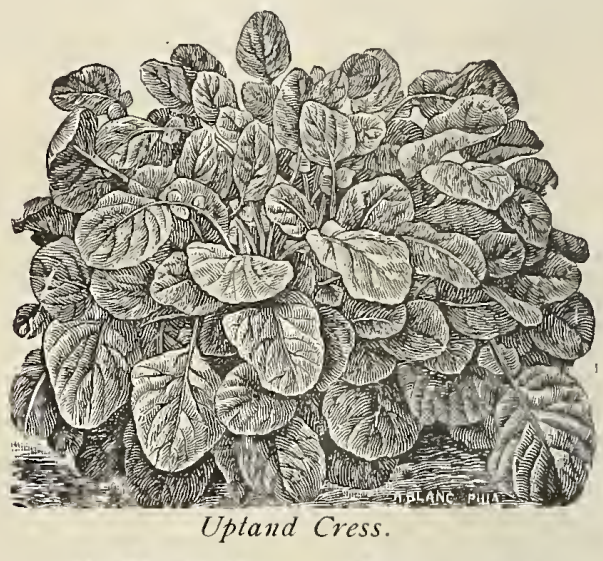

\section{CRESS =-Water.}

Wasser Kresse-Crescione Acquatico.

This is a well-known hardy, perennial aquatic plant, growing abundantly along the margins of running streams, ditches and ponds. Where it does not grow naturally it is easily introduced by planting along the margins of ponds or streams, where it increases, both by spreading of the roots and by seeding.

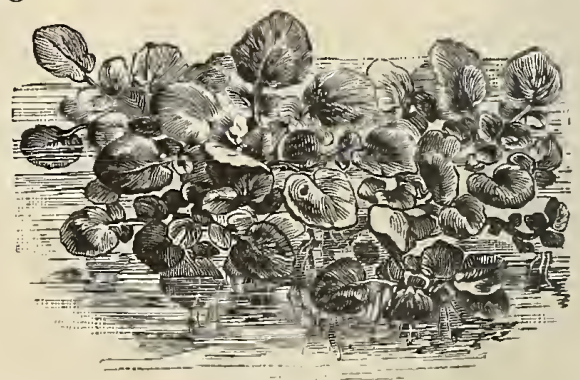

Water Cress.

True Water Cress. Price per pkt., Ioc.; per oz., $35 \mathrm{c}$. 


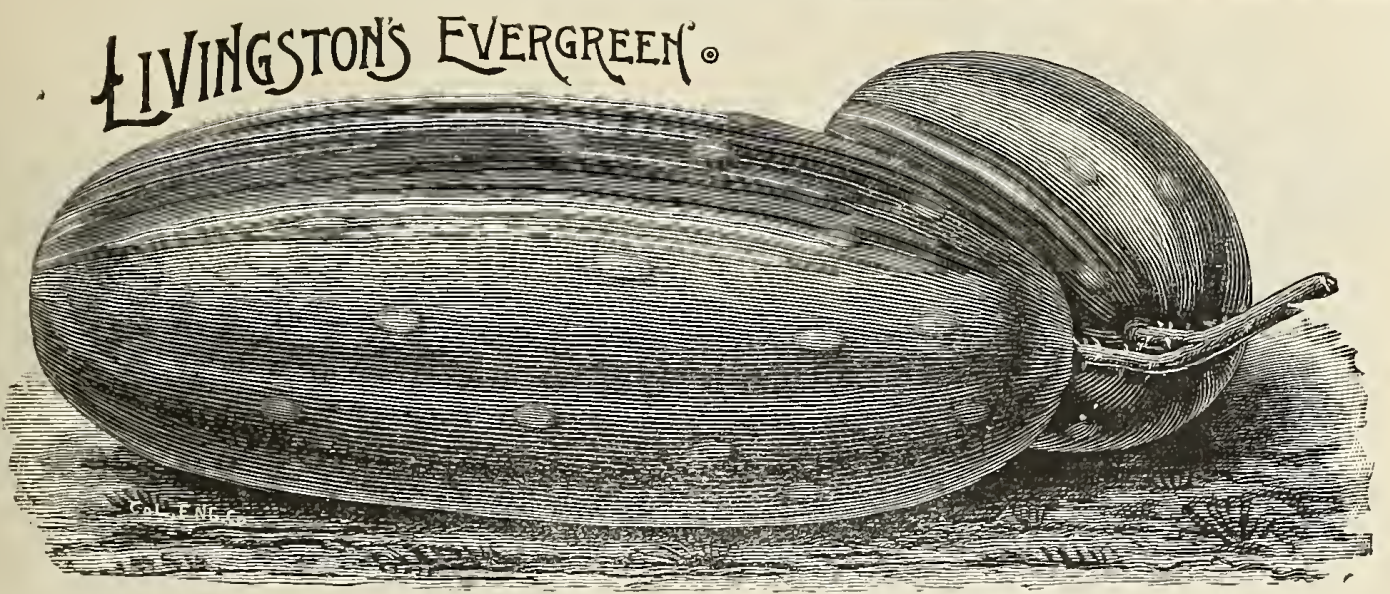

\section{CUGUMBER.}

Gurke-Pepino-Cetrinolo.

Make ricli hills of well-rotted manure, two feet in diameter, and plant a dozen or more seeds, covering half an inch deep. When all danger from insects is over, pull all but three or four of the strongest plants. The middle of June is early enough to plant for pick. ling. Make the hills about six feet apart. For early cucumbers the llot-bed is necessary.

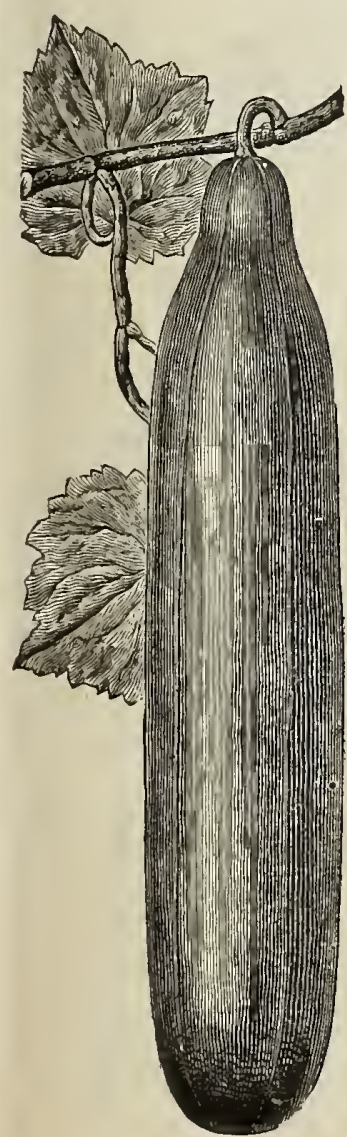

Giant Pera.
Livingston's Evergreen. A very strong grower, early, bearing firm, crisp fruits, either for pickling or slicing. Price per pkt., 5c.; per oz., Ioc.; per $1 \mathrm{~b}$., $60 c$.

White Pearl. It is distiuct in character; milky-white surface, large and prolific; good for slicing as a green table cucumber. Price per "pkt., 5c.; per oz., Ioc.; per lb., 65 c.

Early Russian. The earliest of all, fruit short, a valuable variety for small pickles. Price per pkt., 5c.; per oz., roc.; per lb., $50 \mathrm{c}$.

Nichol's Medium Green. This variety is a good pickle sort, while it is medium size and prolific. Price per pkt., 5c.; per oz., Ioc.; per lb., 6oc.

Early Cluster. Very early and bears mostly clus ters, near the root. Price per pkt., 5c.; per oz., Ioc.; per 1b., 5oc.

Early Frame. M e d i u m size, good for table use or pickling; a good kind for forcing. Price per pkt., 5c.; per oz., Ioc.; per lb., $50 c$.

Boston Pickling. It is medium long, good colos and a great producer. Price per pkt., 5c.; per oz., Ioc.; per 1b., 6oc.
Short Green or Gherkin. Mediuu in size. Excellent for pickling, very prolific. Price per pkt., 5c.; per oz., I oc.; per 1b., 5oc.

The Emerald. (See Novelties, page 4.) Price per pkt., 5c ; per oz., I 5c.; per 1b., \$I.oo.

Arlington Early White' Spine. For both market use and pickling. Price per pkt., 5c.; per oz., Ioc.; per 1b., 6oc.

Bennett's or Peerless White Spine. A large variety. The fruit is straight and well formed; full at both euds. Price per pkt., 5c.; per oz., Ioc.; per 1b., 6oc.

Evergreen White Spine. They grow long and very straight, make fine, hard, brittle pickles when five to six inches long. Price per pkt., 5c.; per oz., IOc.; per $1 \mathrm{~b} ., 60 c$.

Early White Spine. A large, snooth and prolific sort, good for all purposes that a cucumber can be applied to. Price per pkt., 5c.; per oz., Ioc.; per lb., $50 c$.

Green Prolific. Medium in size, very prolific and used generally for pickling. Price per pkt., 5c.; per oz., Ioc.; per lb., 6oc.

London Long Green. Dark green. Fine for large pickles or cutting up. Price per pkt., 5c.; per oz., Ioc.; per 1b., 6oc.

Giant Pera. Grows very large, frequently to one and a half feet iu length, very smootl and straight. Price per pkt., 5c; per oz, roc.; per 1 b., $\$$ I.oo.

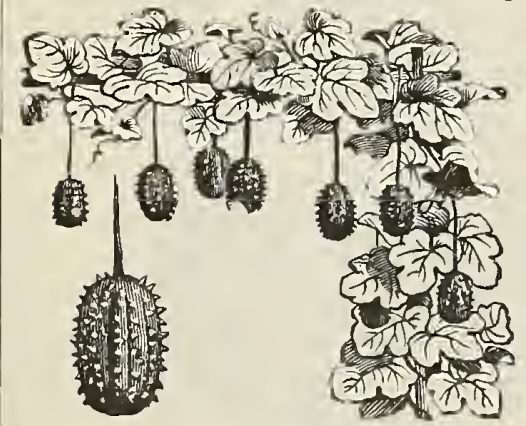

Gherkin or West India.
Gherkin or West India. Very $s$ mall and used for pickles only; extrenely prolific; the vine resenubles the water - melon and may be ruu over an arbor or trellis. Price per plet., 5c.; per oz., Ioc.; per 1b., $\$$ I.Oo.

Japanese Climbing. Vines are vigorous, and throw out strong grasping tendrils. Skin dark green. flesh pure white. Price perpkt., 5c.; per oz., 10c.; perlb.,6oc.

Snake. A singular shaped vegetable, piesenting a very curious formation, and quite suggestive of the name. Price per pkt., Ioc.

Telegraph. Best for hot-house culture, and will do well out doors in light soil, the fruit growing twelve to eighteen inches long. Price per pkt., 20c. 


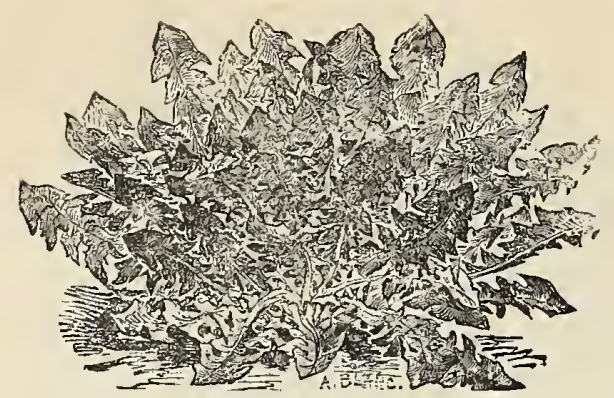

Dandelion.

\section{DANDELION.}

Löwenzahn-Amaigon-Cicorea.

The Dandelion affords one of the earliest as well as one of the best and most healthful spring greens. It is also sometimes blanched and used as a salad. The seeds may be sown in May, in drills tev. inches apart; thiu out the young plants about three inches apart; cultivate during the season, and the following spring the plants will be fit for the table.

Improved Large Leaved. Price per pkt., 5c.; per oz., 4oc.; per 1b , \$4.0o.

\section{EGG PLANT.}

Eierpflanze-Berengena--Moliguane.

Sow in a hot-bed in February and March; when the plauts are one or two inches high, transplant or thin out to two or three inches apart. When the weatner is warm and settled, they may be planted out in a warm situation, two feet apart each way.

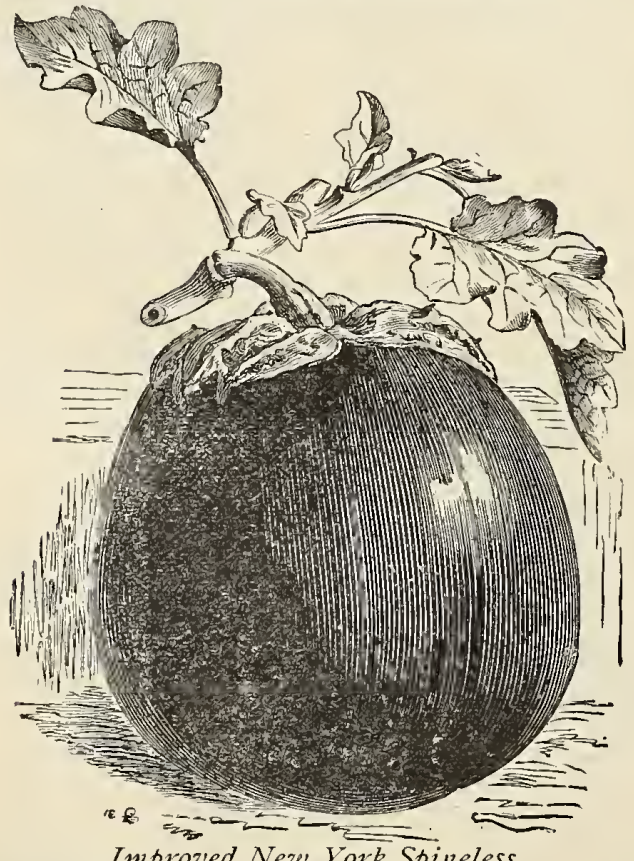

Improved New York Spineless.

Improved New York Spineless. The plant is low and branching and quite free from spines, fruit of large size and perfect form. Price per pkt., 5c.; per oz , 3oc.; per 1b., \$3.00.

Black Pekin. Fruit very large, solid and dark purple. Per pkt., 5c.; per oz., 3oc.; per 1b., \$3.00.

\section{ENDIVE.}

Endivien-Endivin-Indivia o Escarola.

Make the first sowing about the middle of May, on a bed of well-pulverized, rich soil, scattering the seed thinly, and covering it lightly. For the main crop, sow in the middle of June and again about the middle of July; and for plants to stand the winter, sow early in August. When the plants are about two inches high, transplant into nursery beds upon rich, wellprepared soil, taking special care not to injure the roots. One ounce will sow a bed about eighty feet square.

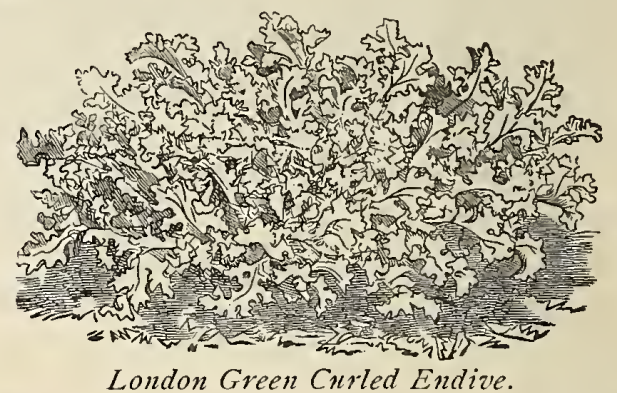

London Green Curled. Leaves curly and finely fringed; very hardy and fine quality. Price per pkt., 5c.; per oz., I 5c.; per 1b., $\$$ I.5O.

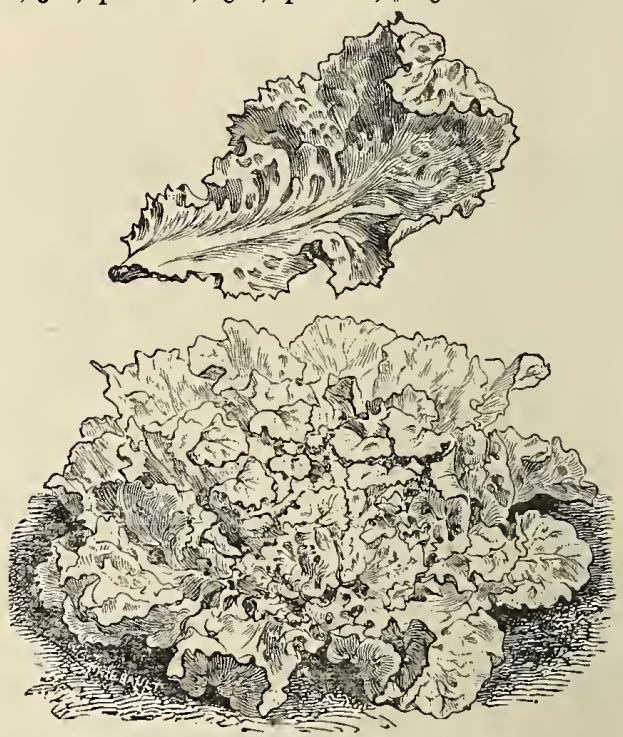

Broad Leaved Batavian Endive.

Broad Leaved Batavian. A large summer variety; chiefly used in soups and stews. Price per pkt., 5c.; per oz., I 5c.; per lb., \$I.50.

\section{FLORENGE OR NAPLES FENNEL. \\ Finocchio di Napoli.}

Sow in early spring in rows fifteen to twenty inches apart, in rich, moist soil. Thin out to six or eight inches. It is usually boiled for the table. It somewliat resembles celery, possessing a sweet and agreeable smell and flavor. Eaten raw when young and tender, but boiled when matured. Price per pkt., 5c.; per oz., I5c.; per 1b., $\$$ I.75. 


\section{GARLIG.}

\section{Aglio.}

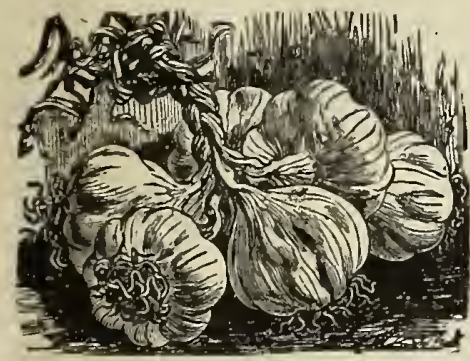

Garlic. in flavoring soups, stews and other dishes.

Garlic thrives best in a light, well-enriched soil; the sets should be planted in early spring, in rows one foot a part and from one to five inches between the plants in the rows. The crop matures in August, when it is harvested like the onion. Used Garlic Sets. Price per 1b., 25c.

\section{KALE OR BORECOLE.}

Blätter Kohl-Col-Cavalo Riccio.

Sow in April, in drills fourteen to eighteen inches apart, covering the seeds thinly and evenly, and thin out when hoeing to from four to six inches apart. The varieties are extremely hardy, and are best when touched by frost. For winter and spring use, sow in August or September.

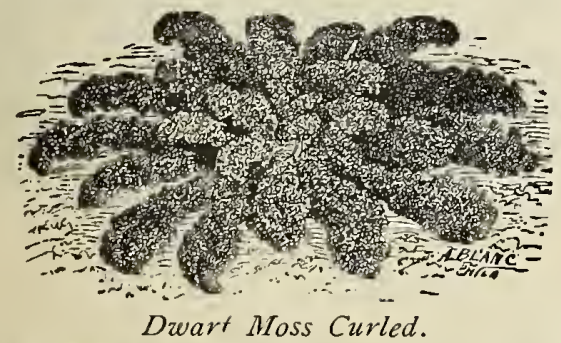

German Greens or Sprouts. Light green, very curly, good for spring or fall sowing. Price per pkt., 5c.; per oz., IOc.; per lb., 6oc.

Dwarf Moss Curled. Very dwarf, light green. Closely curled and crimpled. Price per pkt., 5c.; per oz., roc.; per lb. \$1.oo.

Dwarf Green Curled Scotch. Very dwarf, of spreading habit, hardy, and improved by light frost. Price per pkt., sc.; per oz., Ioc.; per lb., $75 \mathrm{c}$.

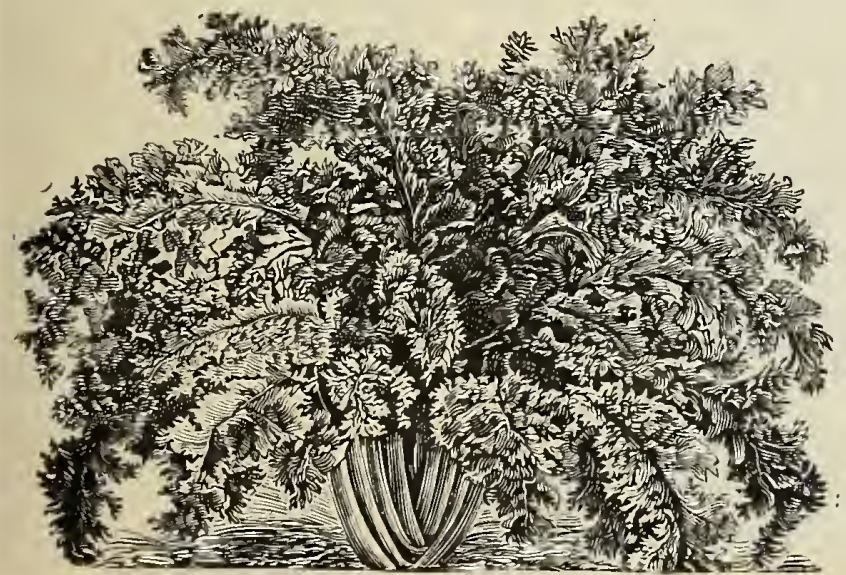

Improved Siberian.
Tall Green Curled Scotch. Similar to the dwarf except that it grows eighteen to twenty-four inches high. Price per pkt., 5c.; per oz., Ioc.; per lb., 6oc.

Improved Siberian. Dwarf, curly, dark-green leaves, very hardy and an immense cropper. Undoubtedly the best adapted to our climate and more extensively grown than any other variety. Price per pkt., 5c.; per oz., Ioc.; per 1b., 5oc.

Purple, Curled or Brown Kale. A beautifully curled variety, witl dark-colored leaves. Price per pkt., 5c.; per oz., Ioc.; per lb., 8oc.

\section{KOHL-RABI OR TURNIP CABBAGE.}

\section{Kohlrabi-Colinabo-Rapa.}

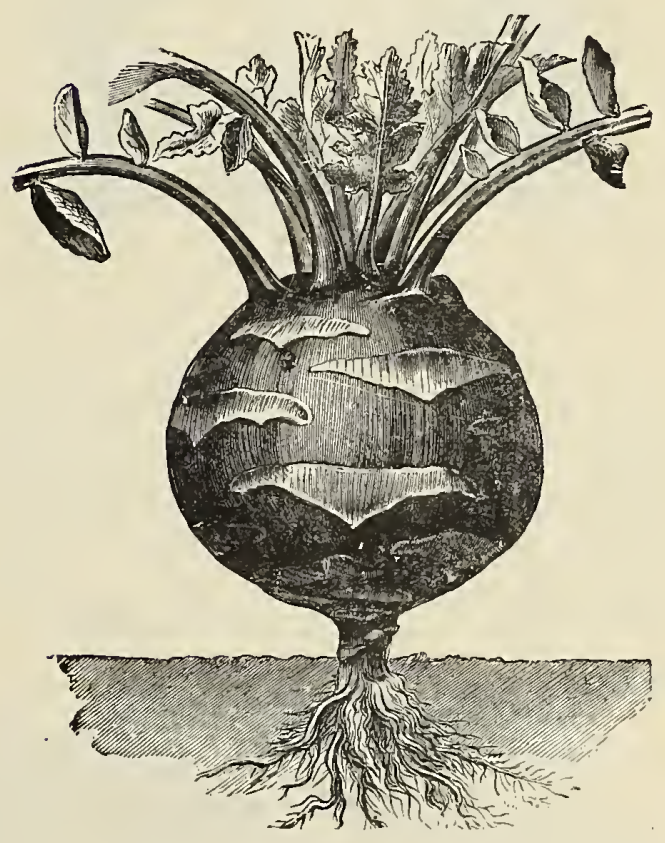

Kohl-Kabi or 7 urnip Cabbage.

Half way between a turnip and a cabbage, partaking of the nature and flavor of both. The bulbs are cooked like turnips. Sow from April to July; plant and cultivate the same as cabbage. Set in drills eighteen inches apart, and eight inches in the drills. As they are difficult to transplant, they are sometimes sown where they are to stand, and afterward thinned out.

Early White Vienna. Grows to a fair size, skin light green, flesh white; short stump and tops. Price per pkt., 5c.; per oz., 15c.; per lb., $\$ 1.50$.

Early Purple Vienna. Differs from the above in color only. Price per pkt., 5c.; per oz., 20c.; perilb., $\$ 2,00$. 


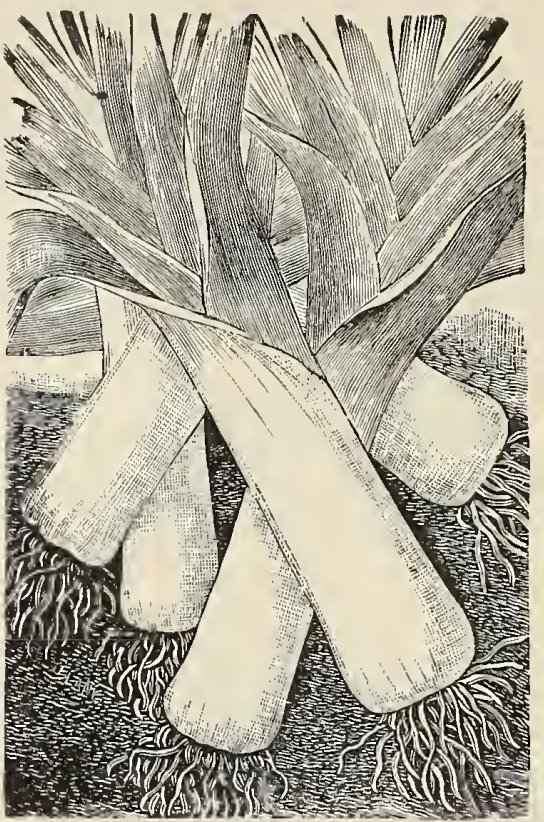

Large Musselburg Leek.

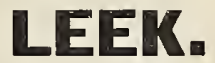

Lauch-Puerro-Cipollette.

Sow as early in the spring as the season admits, either in seed beds or places where they are intended to grow. When four inches in height thin to three inches; when from six to eight, transplant to ten inches apart, leaving those in the drills about six inches apart. Set as deep as possible without covering the small center leaves.

Large Musselburg. The largest and most prolific. Price per pkt., 5c.; per oz., I5c.; per $1 \mathrm{~b}$. , $\$ \mathbf{I} .50$.

American Flag. A large and strong plant. Price per pkt., 5c.; per oz., I5c.; per $1 \mathrm{~b} ., \$ \mathrm{I} .25$.

Large Rouen. A large variety remaining long in good condition, and sometimes called Winter Rouen. Price per pkt., 5c.; per oz., I 5c.; per 1b., \$I.5o.

\section{LETTUGE. \\ Salat-Lechuga-Lattuga.}

Culture. Sow early in spring in a hotbed; transplant in April for summer use. Again, sow from April at intervals in the open ground, and for winter and

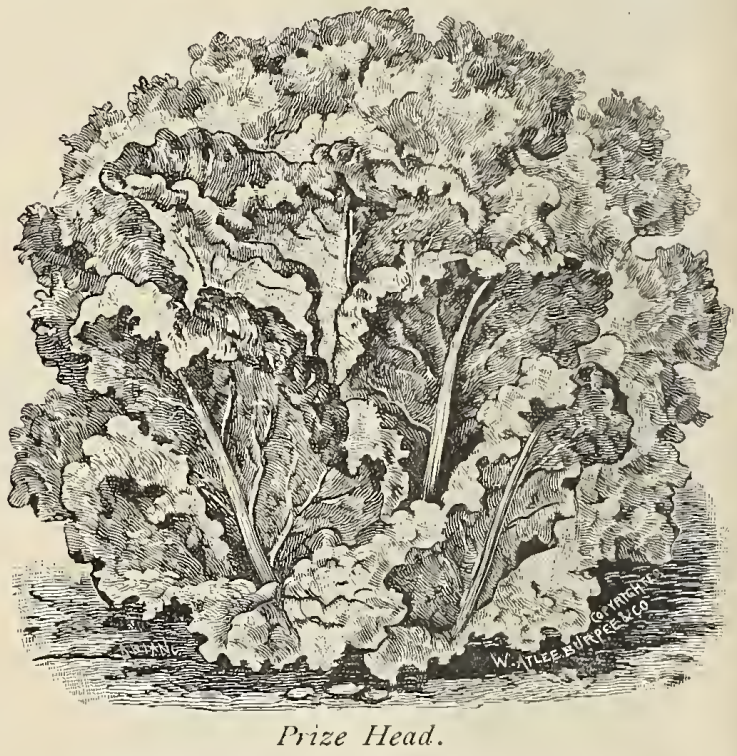

spring use, in August and September. Protect by means of a cold frame during the winter.

Prize Head. Forms large, loose heads of bronzed-

edged leaves. Price per pkt., 5c.; per oz., I5c.; per $1 \mathrm{~b}, \$ \mathrm{I} .25$.

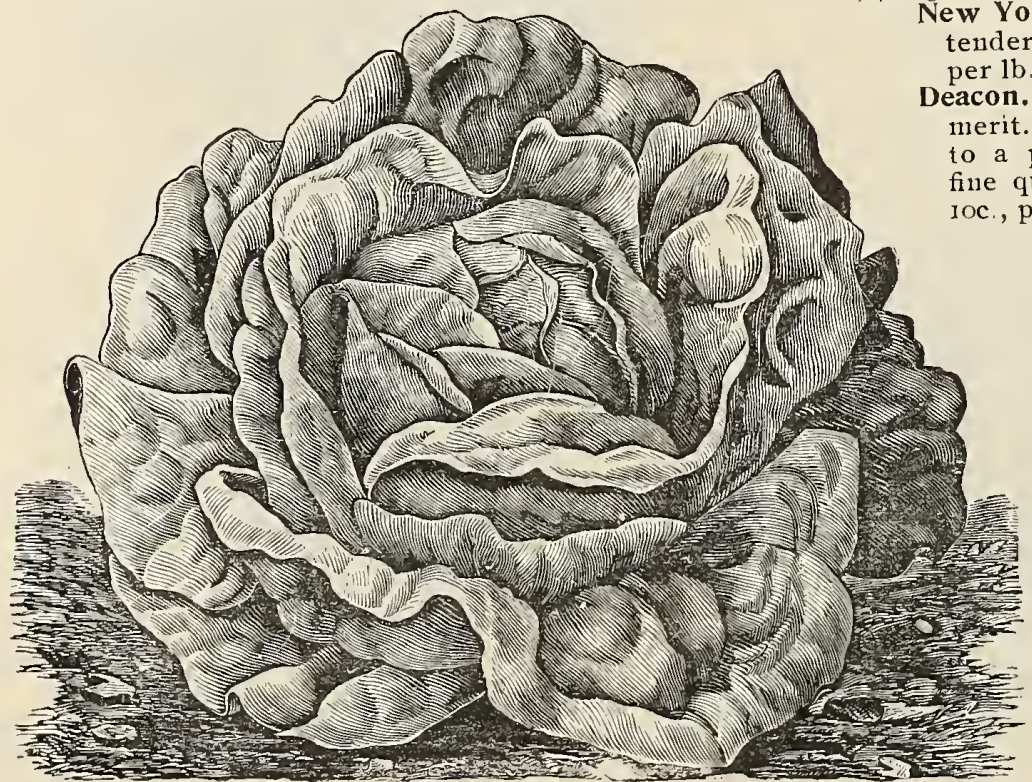

The Deacon.
New York. It grows large and is crisp and per lb, 8oc.

pen. A large Butter-Head variety of great merit. Outer leaves are light green shading to a pale yellow center of exceptionally fine quality. Price per pkt., 5c.; per oz., oc, per 1b., \$I.oo.

Tennis Ball Black Seeded. One of the earliest; forms a close, harit head, not large, but very tender and crisp. Price per pkt., 5c.; per oz., Ioc.; per 1b., \$I.OO.

Boston Market or White Seeded Tennis Ball. Grows very compact, one of the best for forcing. Price per pkt., 5c.; per oz., Ioc.; per 1b., \$I.oo.

Big Boston. Large head, excellent for forcing. Price per pkt., 5c.; per oz., I oc.; per 1b., \$I. 00 .

Grand Rapids. This is a very large, thin-leaved, curly-head lettuce. Price per pkt., 5c.; per oz., Ioc.; per 1b., 8oc. 
LETTUGE-continued.

Salat-Lechuga-Lattuga.

Early Curled Silesia. Very early, tender and crisp; forming close center but not heading. Price per pkt., 5c.; per oz., Ioc.; per 1b., 8oc.

Early Curled Simpson. Resembles Silesia, but grows larger. Price per pkt., 5c.; per oz., Ioc.; per lb., 9oc.

Black Seeded Simpson. It does not properly form a head, but a compact mass of leaves; stands the sumn1er heat excellently, and attains a large size. Price per pkt., 5c.; per oz., Ioc.; per 1b., \$I.oo.

Denver Market. It forms large solid heads of a good light green color. Price per pkt., 5c.; per oz., Ioc.; per 1 b., goc.

White Summer Cabbage. A fine large-headed variety, and one of the best for garden culture. Price per pkt., 5c.; per oz., Ioc.; per 1b., 8oc.

Hubbard Market. A large white cabbage variety; equally valuable for forcing or open ground. Price per pkt., 5c.; per oz., Ioc.; per 1 h. \$I.00.

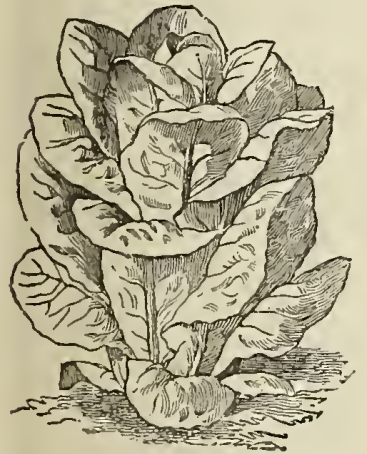

Paris White Cos Lettuce.
Satisfaction or Salaman= der. One of the best for $\mathrm{s} u \mathrm{~m}$ mer use, forming good-sized, compact heads. Price per pkt., 5c., per oz., Ioc.; per lb., $\$ \mathrm{I}$ Oo.

Hanson. Heads very large and solid, sometimes weighing two or three pounds. Price per pkt., 5c.: per oz., I5c.; per lb., $\$ 1.25$.

Brown Dutch. Round head, leaves edged with brown, very hardy and good quality. Price per pkt., 5c.; per oz., I5c.; per 1 b.,

Paris White cos. This grows upright, with long, narrow leaves, and should be tied up to blanch a week or more before cutting. Price per pkt., 5c.; per oz., I5c.; per 1b., \$I.25.
The Petoskey or Paul Rose Musk=melon. It is a cross between the Osage and Netted Gem, and combines the best features of the originals. The fruit is oval, medium size, dark exterior, thickly netted; with rich salmon flesh, so thick as to nearly close the seed cavity. Price per pkt., 5c.; per oz., เoc.; per 1b., goc.

Osage or Miller's Cream. This is a popular variety, medium size, thick, hard, salmon flesh, decidedly rich and sugary. Price per pkt., 5c.; per oz., Ioc.; per 1 b., 5oc.

Delmonico. Flesh, an orange-pink color. The melons are oval shaped and very deeply netted. Price per pkt., 5c.; per oz., Ioc.; per 1b., 6oc.

Emerald Gem. This variety is sma11, but prolific. Has a thin green rind and very small seed cavity, almost the entire body of the fruit consisting of rich, luscious meat of a salmon color. Price per pkt., $5 \mathrm{c}$.; per oz., Ioc.; per 1b., 6oc.

Hackensack. It attains a large size, is round in shape, flattened at the ends, green flesh, most deliciously flavored and wonderfully productive. Price per pkt., 5c.; per oz., Ioc.; per 1b., 5oc.

Anne Arundel or Acme. Very large round, flattened at both ends, flesh green, thick and fine flavored. Price per pkt., 5c.; per oz., Ioc.; per lb., $50 \mathrm{c}$.

Golden Netted Gem. Flesh light green in color, and of fine luscious flavor, skin green, regularly ribbed and thickly netted. Price per pkt., 5c.; per oz., IOc.; per 1b., 6oc.

Surprise. Skin cream colored, thickly netted; flesh thick, of bright salmon color, and excellent flavor; early and fair size. Price per pkt., 5c.; per oz., Ioc. per $1 \mathrm{~b} ., 75^{\mathrm{c}}$.

Tip=Top Nutmeg. This is a very large melon, deeply ribbed, and thickly netted skin. The flesh is green, thick, very sweet and delicious. Price per pkt., $5 \mathrm{c}$, , per oz., Ioc.; per 1b., 6oc.

Nutmeg. Grows to a good size, nearly round, thickly netted, green flesh. Price per pkt., 5c.; per oz., Ioc.; per $1 \mathrm{~b} ., 50 \mathrm{c}$.

\section{MUSK-MELON.}

\author{
Cantalupe-Melon Muscatel \\ -Popone o Mellone.
}

Culture. Plant in the spring, in hills five or six feet apart each way, well manured with old rotten compost. Scatter a dozen seeds to the hill, and after they are out of danger from bugs, thin to three or four plants. A light, dry, sandy soil and a dry atmosphere are most suitable. Melons should not be planted near any other varieties if it is desired to preserve them pnre.

Rocky Ford. This is an oval-shaped melon of medium size and thickly netted. The flesh is green, firm, sugary and of exquisite flavor. Price per pkt,, 5c.; per oz., Ioc.; per 1b., 8oc.

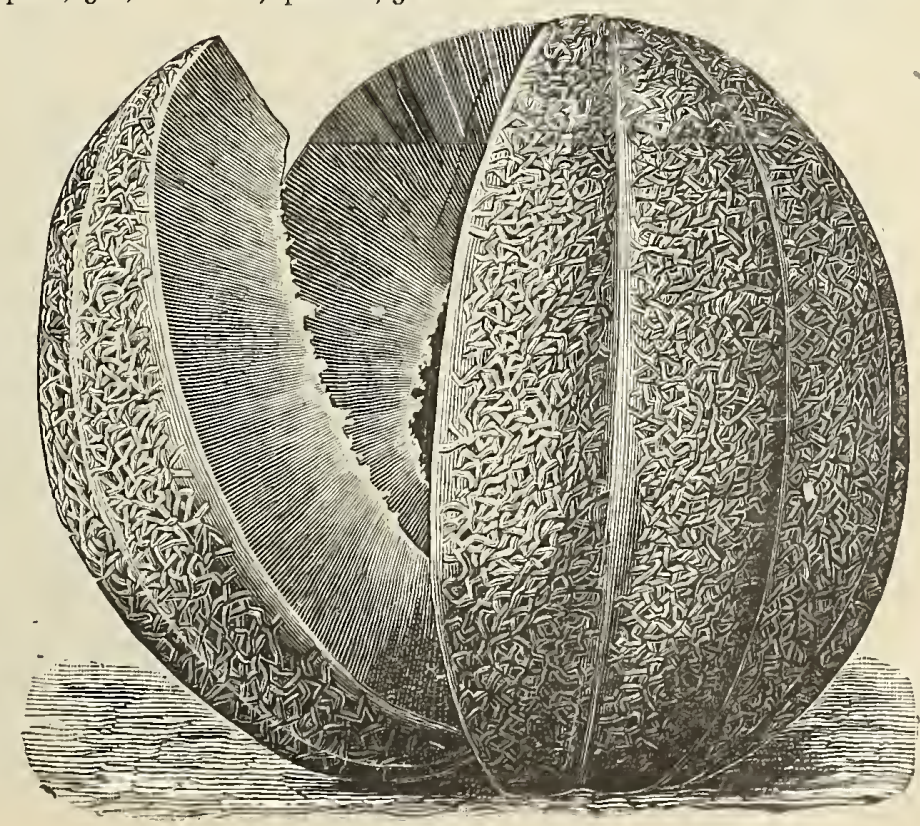

Osage. 


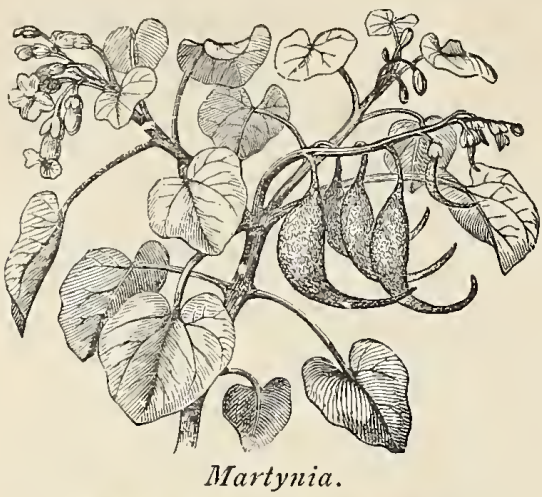

MARTYNIA.

The seed pods are used to a considerable extent for pickling, when gathered green and tender. Sow in the open ground in May, and transplant two feet apart. Martynia Proboscidea. Price per pkt., 5c.; per oz., 25c.; per 1 b., $\$ 2.50$.

\section{WATER-MELON.}

Wassermelone-Zandia-Anguria o Mellone.

Culture. Plant in hills six or eight feet apart, in May. Select warm, light, dry grouud, and in preparing the hills let them be dug out as broad and deep as the soil will admit; fill at least one-third full of the best decomposed stable manure, and mix thoroughly with the soil; fill up a little above the level of the ground.

Cole's Early. A striped early variety, nearly round, medium size, crimson flesh of superior quality. Price per pkt., 5c.; per oz., Ioc.; per 1b., 6oc.

Phinney's Early. Flesh deep red; superior quality, early and productive. Price per pkt., 5c.; per oz., Ioc.; per 1b., 6oc.

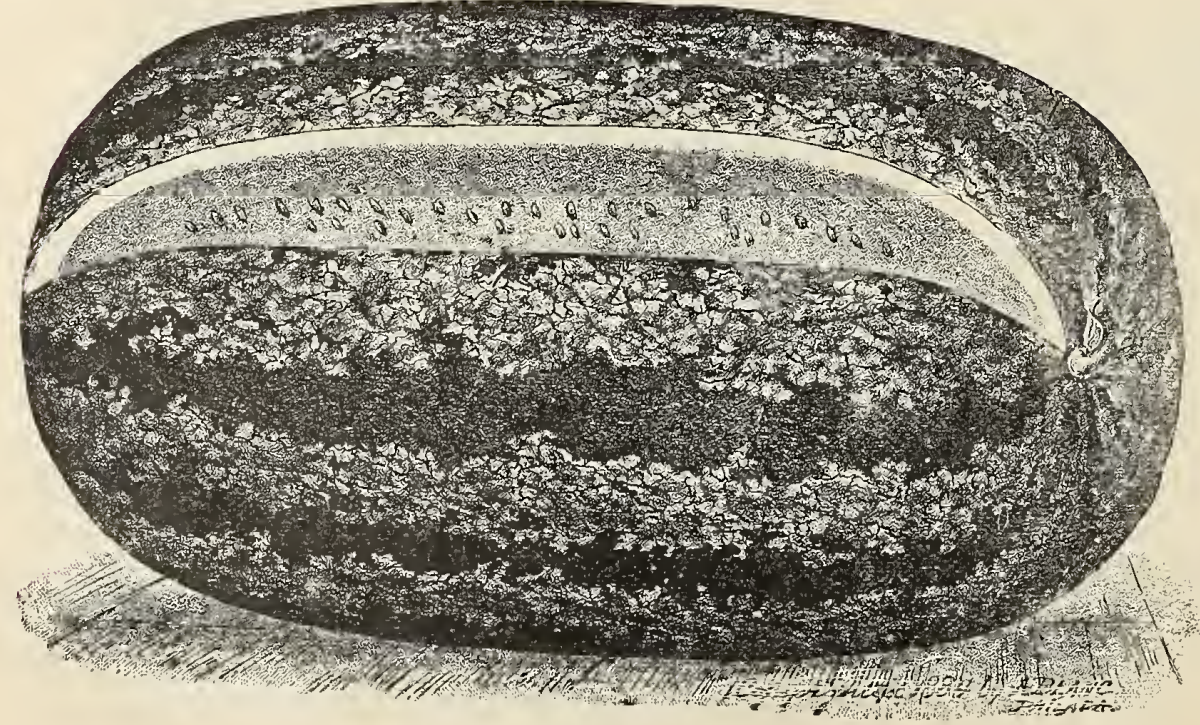

Dixie.

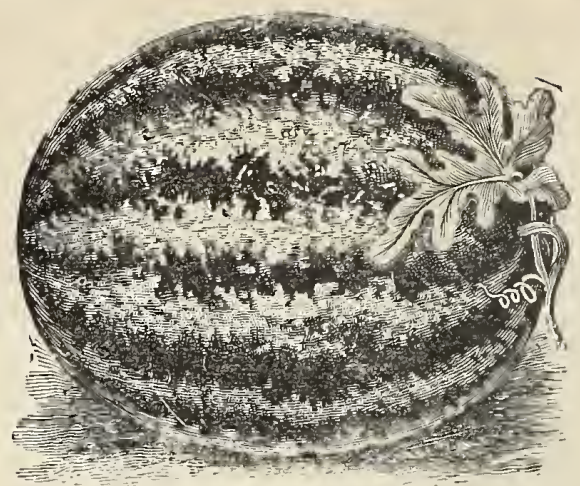

Cole's Early.

The Triumph. (See Novelties, page 3.) Rind dark green color. Seed large and dark. The flesh is bright red. It is very early, large and prolific. Price per pkt., 5c.; per oz., IOc.; per lb., \$I.oo.

Hungarian Honey. This is a small melon with dark green exterior. It is richer and sweeter than any other water-melon, ripening thoroughly up to within one-fourth inch of the outer skiu. The seeds are very small. It is early and very productive. Price per pkt., 5c.; per oz., Ioc.; per lb., 6oc.

Jordan Gray Monarch. The skin is a mottled gray, shape long, flesh bright crinuson. Price per pkt., 5 c.; per oz., IOc.; per 1 b., $50 \mathrm{c}$.

Seminole. It is oblong in shape. Two colors, gray and light green. Melons of both colors are frequently found ou the same vine. It is extra early, large and productive. Price per pkt., 5c.; per oz., IOc.; per $1 \mathrm{~b} ., 50 \mathrm{c}$.

Dixie. It is productive, fine quality and fine flavor. It has a remarkably hard but very thin riud. Price per pkt., 5c.; per oz., roc.; per 1b., 6oc.

Kolb's Gem. This is a striped oblong melon, of large size, solid, and rich in quality. Price per pkt., 5c.; per oz., Ioc.; per lb., 5oc.

Pride of Georgia. Dark green in color, nearly round, and grows partly upon its end. Flesh bright crimson and very fine white seeds. Price per pkt., $5 \mathrm{c}$.; per oz., Ioc.; per lb., 5oc.

Ice Cream or Peerless. Wlite seed; of medium size, early; green skin, very thiu rind; flesh solid, scarlet, crisp. Price per pkt., 5c.; per oz., Ioc.; per $1 \mathrm{~b}$., $50 \mathrm{c}$.

Cuban Queen. This is a large variety; skin is striped, flesh bright red, remarkably solid. Price per pkt., 5c.; per oz., IOc.; per $1 \mathrm{~b} ., 50 \mathrm{c}$.

Mountain Sweet. One of the best for general culture; color dark green; rind thiu; flesh solid, scarlet, sweet aud delicious. Price per pkt., 5c.; per oz., Ioc.; per 1b., $50 c$. 
Citron for Preserves and Sweetmeats. Rouud, striped, very productive. Price per pkt., 5 c.; per oz., 1oc.; per $1 \mathrm{~b} ., 75 \mathrm{c}$.

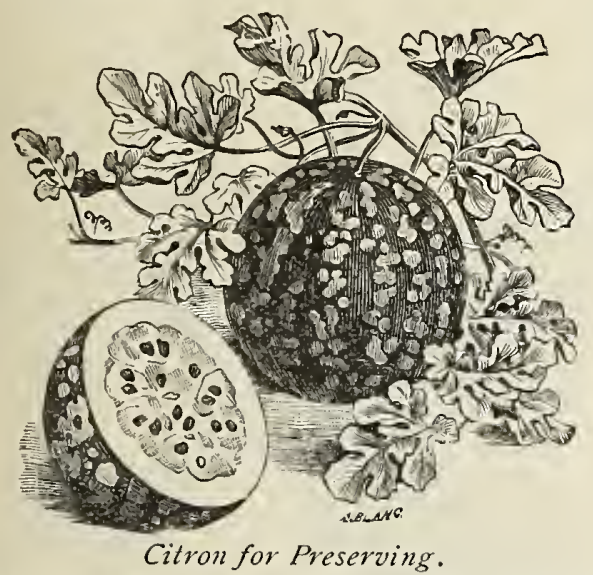

Colorado Preserving Citron. Grows to a very large size, ofteu thirty to forty pounds; flesh very firm and solid. Price per pkt., 5c.; per oz., 1oc.; per 1b., $75 \mathrm{c}$.

\section{MUSHROOM SPAWN.}

Champignonbrut-Seta-Funghi.

Mushrooms may be cultivated much easier than is generally supposed. They may be grown iu a cellar or shed, or in beds prepared in the open air in the same

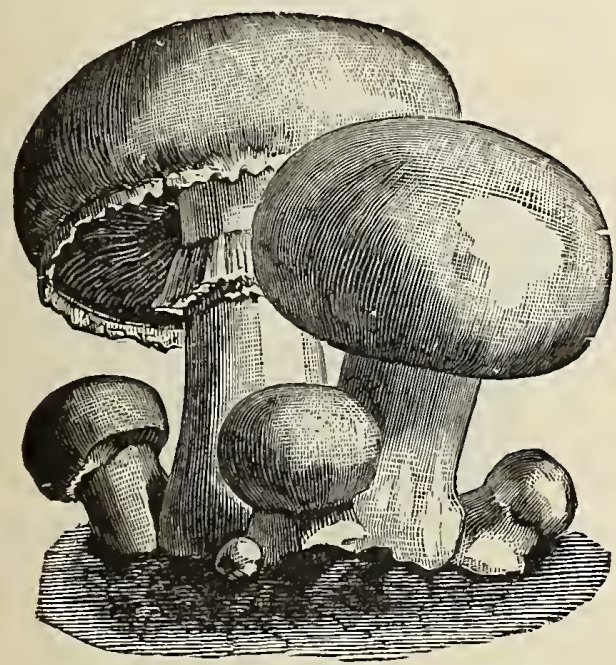

Nushrooms.

manner as hotbeds. Price per 1b., I2c.; Io lbs. for $\$ 1.00$, in bricks.

\section{MUSTARD. \\ Senf-Mostaza-Mortarda.}

Sow in April, in drills a foot apart, and thin out noderately when about three iuclies ligh.

White London. The seed is grouud and used for various purposes. Used for salads or greens. Price per oz., 5c.; per 1b., $20 c$.
Brown or Black. More pungent in flavor thau the white. Price peroz., 5c.; per lb., 2oc.

New Chinese. Leaves twice the size of the ordinary White Mustard. Price per pkt., 5c.; per oz., Ioc.; per lb., 6oc.

\section{NASTURTIUM OR INDIAN CRESS.}

Nasturtium-Maraneula-Narturzio.

Plant in April and May in rows; the climbing varieties to cover some trellis, or twine around poles or other support; the dwarf kiud in rows or hills, tliree feet a part, along a border or walk. The seeds, when tender enough to be easily punctured by the finger nail, are used for pickles.

Dwarf. Mixed. This grows from six inches to a foot in heiglit. Price per pkt., 5c.; per oz., roc.; per lb., 8 oc.

Tall. Mixed. An ornamental climber. From six to ten feet. Price per pkt., 5c.; per oz., Ioc.; per lb., 8 oc.

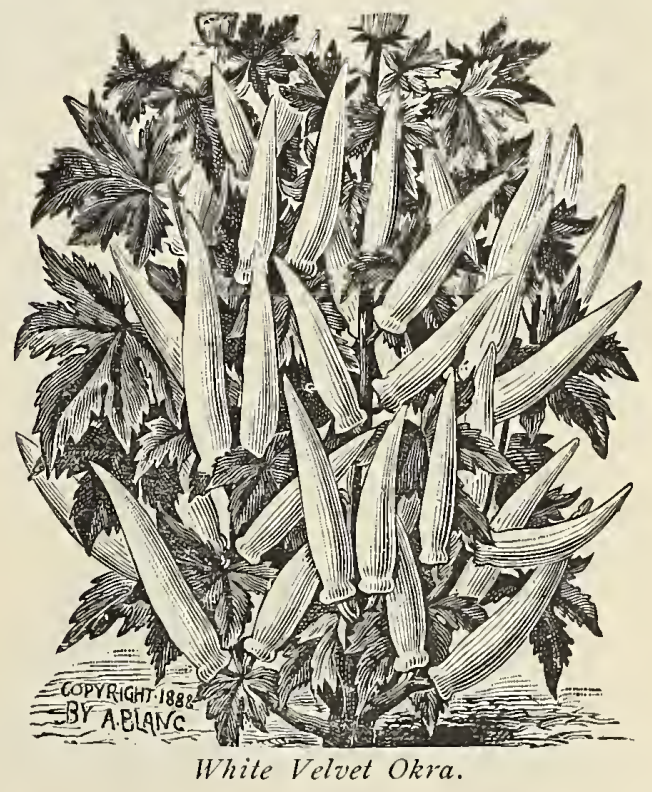

\section{OKRA OR GOMBO.}

Safran-Quimbombo-Ochro.

Select warm, rich soil and plaut in rows two feet apart, thinning plauts a foot apart in the row. The pods are used to thicken soups, being gathered young. Okra is preserved for winter use by slicing the pods into rings and drying them upon strings liung up aud exposed to the air.

White Velvet. Pods round, smooth, free from seams, very prolific. Price per pkt., 5c.; per oz., roc.; per 1b., 5 oc.

Dwarf Green Prolific or Density. A very dwarf and prolific variety. Pods green, smooth and thickly set. Price per pkt., 5c.; per oz., 1oc.; per 1b., 6oc, 


\section{ONIONS.}

Zwiebel-Cebolla-Cipolle.
Onion seed should be sown as early as it is possible to work the ground, in drills one inch deep and twelve to sixteen inches apart, in rich soil, deeply dug and lightly rolled. Thin to one inch apart. When sowing for sets, seeds must be put in very thick, at the rate of about twenty pounds to the acre. The same patch may be used year after year for onions and never made too rich.

Danvers Yellow Globe. Large, nearly round, and productive; very mild, ripens early, and is a good keeper. Price per pkt., 5c.; per oz., I5c.; per 1b., $\$ 1.25$

South port Yellow Globe. My seed of this valuable, heavy cropping sort is raised from the finest Southport Onions. Price per pkt., 5c.; per oz., I5c.; per 1b., \$r.5o.

Yellow Dutch or Strasburg. Large and flat. A great yielder. Sown extensively for sets. Price per pkt., $5 \mathrm{c}$; per oz., Ioc.; per 1b., $\$ \mathrm{I} .00$.

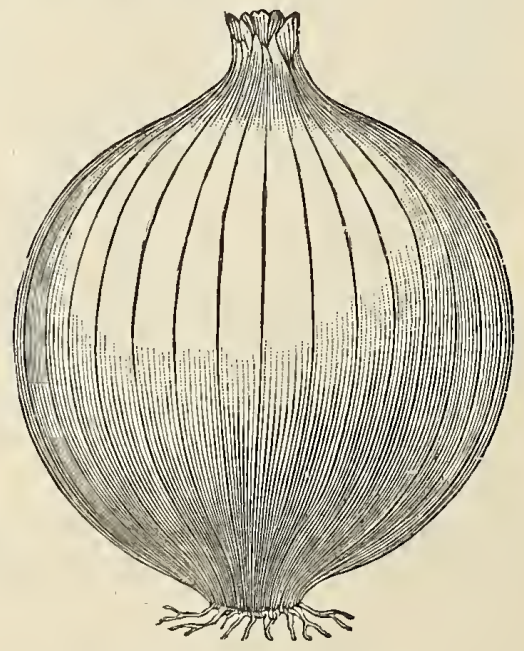

Southport White Globe.

Southport White Globe. In form nearly ovoid, very regular and symmetrical; skin white, mild and pleasant flavor. Price per pkt., 5c.; per oz., 25c.; per 1b., \$2.50.

Large Red Wethersfield. A large flat variety, keeps well, and is mild in flavor. Price per pkt., 5c.; per oz., I5c.; per 1b., \$I.50.

Extra Early Red. About ten days earlier than Large Red. Price per pkt., 5c.; per oz., I5c.; per $1 \mathrm{~b} ., \$ \mathrm{I} .50$.

White Portugal or Silver Skin. Very early, mild flavor, prized for pickling. Price per pkt., 5c.; per oz., $25 \mathrm{c}$.; per $1 \mathrm{~b}, \mathbf{\$} 2.50$.
Large Yellow Spanish or Prize Taker. Tley are rich straw color and of enormous size. The flavor is mild and delicate. Price per pkt., 5c.: per oz., I5c.; per 1b., $\$$ I.5O.

Australian Brown. Nearly round, medium size, with skin of a deep amber brown, extremely hard and firm, of fine flavor and will keep alnıost indefinitely. Price per pkt., 5c.; per oz., I5c.; per 1b., \$1.50.

Red Globe. This is a large, round, deep redskinned variety; very mild, good keeper. Price per pikt., 5c.; per oz., 2oc.; per lb., $\$ 2.00$.

\section{ONION

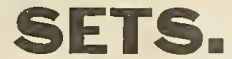

Onion sets, both rareripes and tops, are placed on the surface, in shallow twelve-inch drills, about four inches apart, and lightly covered. Potato onions are planted in spring or fall, as they will survive the winter. By this process early onions may be obtained several weeks earlier than from seed.

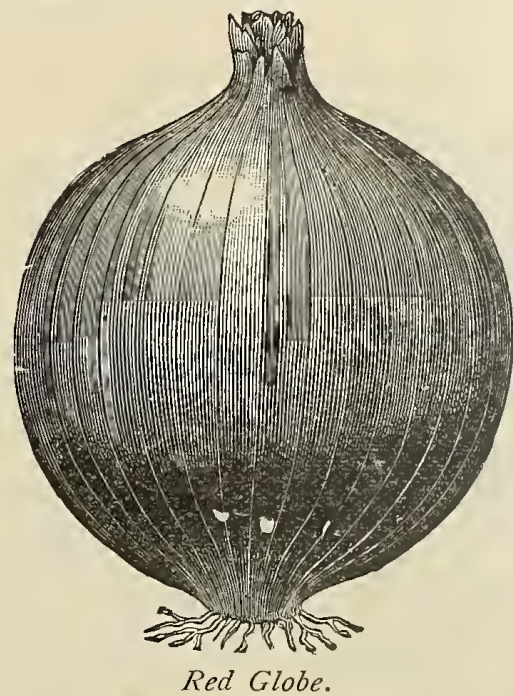

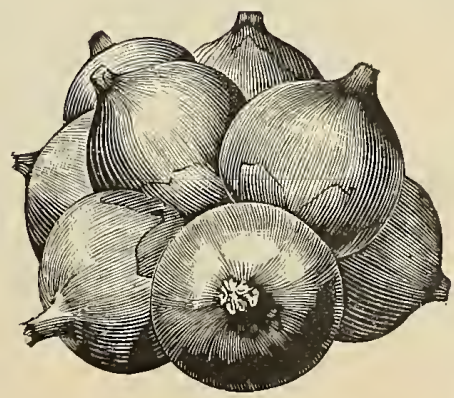

Potato Onion Sets.
White Onion Sets. Per qt., I5c.

Yellow Onion Sets. Per qt., I 5c.

Red Onion Sets. Per qt., I5c.

Potato Onion Sets. Per qt., 2oc.

Egyptian or Perennial Tree. Perqt., I5c.

Shallots. Per qt. I 5 c.

For sets in quantily, get special quotations, as prices vary during the season of planting. 


\section{PARSLEY.}

Petersilie-Periil-Prazzemolo.

Parsley succeeds best in rich, mellow soil. As the seeds germinate very slowly, three or four weeks elapsing sometimes before it makes its appearance, it should be sown early in spring. Sow thickly in rows a foot apart and half an inch deep. For winter use, protect in a frame or light cellar.

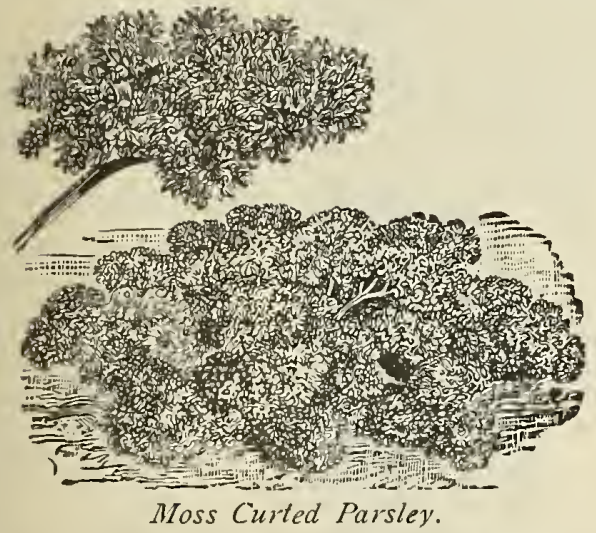

Champion Moss Curled. Very closely curled and good color. Price per pkt., 5c.; per oz., IOc.; per lb., 5 oc.

Fern Leaf. A fine curled, fern-like variety. Price per pkt., 5c; per oz., Ioc.; per 1b., 50c.

Plain Leaf. This is hardier than the curled varieties. Price per pkt., 5c.; per oz., Ioc.; per 1b., 5oc.

\section{PARSNIPS.}

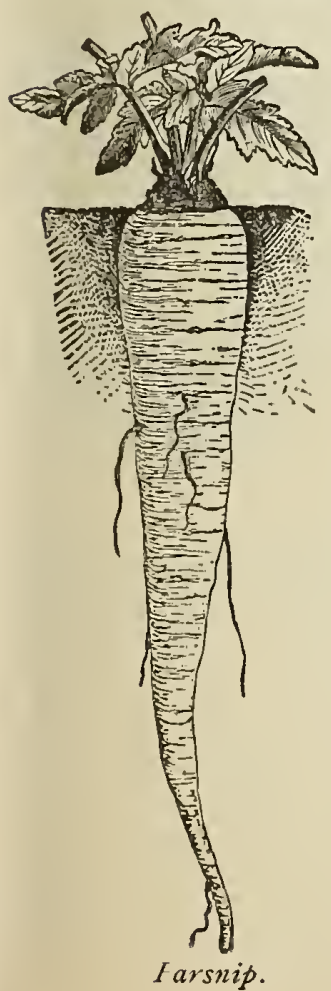

\section{Pastinake}

\section{- Chirijia \\ -Pastanache.}

Sow as early in spring as the weather will admit, in drills fifteen inches apart, covering lightly. When well up, thin out to five or six inches apart in the rows, Unlike carrots, they are improved by frost, and it is usual to take up in the fall a certain quantity for winter use, leaving the rest in the ground intil spring, to be dug up as required.

Long White Smooth.

These grow large and quite long, free from side roots, white, sweet and excellent flavor. Price per pkt., $5 \mathrm{c}$.; per Oz., IOc.; per lb., 5oc.

Hollow Crowned or Guernsey. The $\mathrm{Hol}$ low Crowns are considered superior to the other kinds. Price per pkt., 5c.; per oz., Ioc.; per 1b., 6oc.

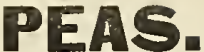

Erbsen-Chichoros-Pirelli.

Wrinkled varieties marked with an *.

Culture. Peas, for an early crop, should be sown as soon as the ground is in working condition. The soil for their reception should be light and dry. For general crops the ground should be well nianured the previous year, which causes them to yield nore abundantly. They are usually planted in double rows, three or four inches a part, and covered to the depth of two and one-half to three inches. All wrinkled peas are superior to and more delicate in flavor than those that present a full and perfect form; like sugar corn, the saccharine matter which they contain causes them to shrivel when dried, and they will remaiu much longer in season than the other kinds.

\section{EARLIEST PEAS. Two to Three Feet High.}

Sunol. It has vigorous vines, growing two and onehalf feet. The seeds are white, round and slightly dented. Price per qt., 20c.; per pk., \$I.10; per bu., $\$ 4.00$.

Early Dexter. Long, large, full pods; a general favorite. Height, two and one-half feet; seed, round, white. Price per qt., I5c.; per pk., $\$ 1.00$; per bu., $\$ 3.50$.

Rural New Yorker. One of the earliest and very productive. Seeds round and slightly dented. Height of vine, two feet. Price per qt., I 5c.; per pk., \$I.oo; per bu,$\$ 3.50$.

Alaska. Very early in growth; first-class in every respect. Seed round, blue, slightly pitted. Height, two and one-half feet. Per qt., 2oc.; per pk., \$I. Io; per bin. $\$ 4.00$.

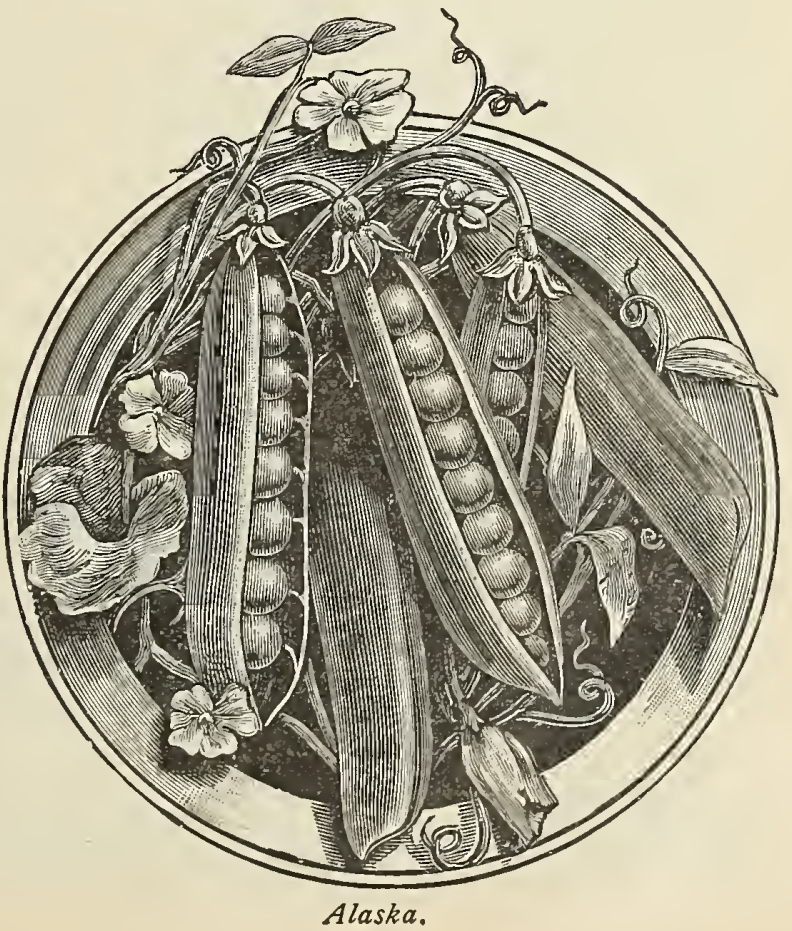




\section{PEAS-Continued.}

First and Best. Extremely early, and ripening with such uniformity that they may be picked clean with one or two pickings. Height, two and one-half feet. Price per qt., I5c.; per pk., $\$ 1$.oo; per bu., $\$ 3.50$.

Daniel O'Rourke. Valuable early June variety; white, round seed. Price per qt., r2c.; per pk., 8oc; per bu., $\$ 3.00$.

Improved Daniel O'Rourke. One of the earliest standard market varieties; white, round seeds. Height, two and one-half feet. Price per qt., I5c.; per pk., $\$ 1.00$; per bu., $\$ 3.50$.

* Nott's Perfection. (See Novelties, page 5.) Price per qt., 4oc.; per pk., $\$ 2.25$; per bu., $\$ 8.00$.

* Gradus. (See Novelties, page 5.) The earliest wrinkled pea. Price per qt., $35^{\mathrm{c}}$.; per pk, $\$ 2.5^{\circ}$; per bu., $\$ 9.00$.

Admiral. Medium early, grows about three feet high. Pods not large but crowded full of very sweet peas. This is a good kind for private garden. Price per qt., 2oc.; per pk., $\$$ r.oo; per bu , $\$ 3.50$.

*Horsford Market Garden. It requires no brushing, is extremely prolific. Height, two feet. Price perqt., 20c.; per pk., $\$$ r.ro; per bu., $\$ 4.00$.

*McLean's Advancer. An early wrinkled variety; second early for market or family use. Height, two and one-half feet. Price per qt., 20c; per pk., \$I.ro; per bu., $\$ 4.00$.

\section{PEAS, DWARF.}

* American Wonder. It is one of the earliest wrinkled peas we have. Dwarf and robust in habit, growing but ten ${ }^{\circ}$ to fifteen inches high. Price per qt., 25c.; per pk., $\$ 1.75$; per bu., $\$ 6.00$.

* Little Gem. Very early and prolific; quality unsurpassed. Meight, twelve inches. Price perqt., 20c.; per pk., $\$ \mathrm{r} .5^{\circ}$; per bu., $\$ 5.00$.

* Early Premium Gem. This is an improved Little Gem, possessing similar qualities. Price perqt., 20c.; per pk., $\$ \mathrm{I} .50 ;$ per bu., $\$ 5.00$.

* Dwarf Telephone. (See Novelties, page 5.) A large wrinkled, half dwarf variety. Vines grow eighteen inches to two feet, and bear profusely. Price perqt., 40c.; per pk., $\$ 2.00$; per bu., $\$ 7.50$.

*Nott's Excelsior. Robust and vigorous in growth, producing in profusion long, hanc!some pods. Seed green, wrinkled. Meight, twelve inches. Price per qt., 25c; per pk., $\$ 1.75$; per bu., $\$ 6.00$.

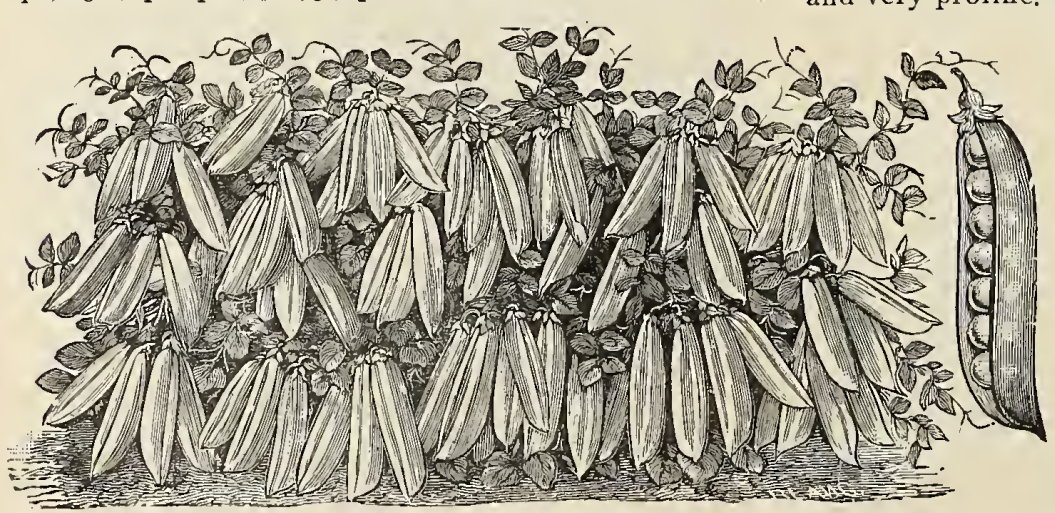

Nott's Excelsior.

GENERAL AND LATE GROP. Two and One-half to Five Feet High.

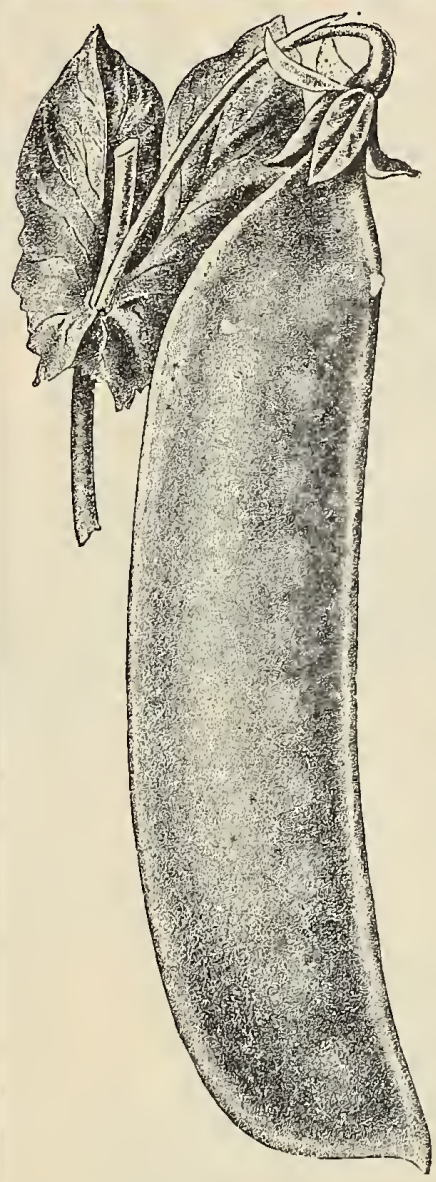

Tall Gray Sugar.
* Heroine. Pods long and slightly curved, well filled with large peas of fine flavor. Height, two feet; seed green and very much wrinkled. Price per qt., 20c.; per pk., \$1.25; per bu., \$4.00.

* Bliss' Ever Bearing. Height of vines, eighteen iuches to tw o feet; foliage very large, firm and bright green; pods three to four inches long on the average. Price per qt., 20c.; per pk., $\$$ r.25; per bu., \$4.00.

Pride of the Market. Height, from eighteen inches to two feet. Seeds are bluish green, slightly dented. Price per qt., 20c.; per pk., $\$ 1.25$; per bu., \$4.50. * Siratagem. Large podded, green wrinkled pea. Height, two and one - half feet. Price per qt. 20c.; per pk., $\$$ r.5o ; per bu., $\$ 6.00$.

* Yorkshire Hero. A large, late wrinkled sort; vines rank and vigorous, but not t a 11 (sometimes called Dwarf Champion.) Height, two and one-half feet.

Price per qt., 20c.; per pk., $\$$ I.25; per bu., $\$ 4$.oo.

* Shropshire Hero. Sinilar to the Yorkshire Hero, but much more abundant. Price per qt., 20c.; per pk., \$I.25; per bu., $\$ 4.50$.

* Telephone. This is a wrinkled variety, and peas of excellent quality. Height, two to three feet. Price per qt., 25c.; per pk., $\$ 1.75 ;$ per bu., $\$ 6.00$.

* Champion of England. An old favorite, rich flavored and very prolific. Meight, five feet. Price per qt. I5c.; per pk., \$I.ro; per bu. $\$ 4.00$.

Long Island Mammoth. Very popular with market gardeners, owing to its large deep green pod. Height, three feet. Price perqt., 20c.; per pk., \$I.Oo; per bu. , $\$ 3.50$.

Whi:e Marrowfat. Correctly nawled, a rich inarrow pea. Height, five feet. Price perqt. Ioc.; per pk., 75c.; per bu., $\$ 2.50$. Black=Eyed Marrowfat. A standard late pea among the marke gardeners; tlie pods grow very large. Height, th:ee feet. Price per qt., roc.; per pik., 75c.; per bu., \$2.50. 


\section{PEAS-Continued.}

\section{EDIBLE PODDED PEAS.}

Tall Gray Sugar. A large porlded, dark seeded variety of superior quality. Price per qt., 25c.; per pk., $\$ 1.50$; per bu., $\$ 5.00$.

Livingston's Prolific Giant Podded Sugar Pea. (See Novelties, page-6:) Pricé per qt., 40c.; per pk., $\$ 2.25$; per bu., $\$ 8.00$.

Tall French Broad Pod Melting Sugar. This bears pods from five to six inches long and an inch wide. The viues grow five feet long, and require support. Price per pkt., 10c.; per pt., 25c.; per qt., 40c.

\section{PEAS FOR SOWING BROADCAST.}

Canada Field. Used for field culture only. In their dry state they are used for feeding stock, making soups, etc. They are usually sown broadcast and often with oats or barley, aud either cut and fed greeu, or left to ripeu aud theu threshed apd ground with oats. Our stock is northeru growu and free from bugs. Price per qt., roc.; per pk., 5oc.; per. bu., $\$$ I.5O.

\section{PEPPERS.}

\section{Pfeffer-Pimiento-Pepperoni.}

Peppers should be started uuder glass. Transplant into the opeu ground towards the close of May, having the rows eighteen inches apart; plants a foot

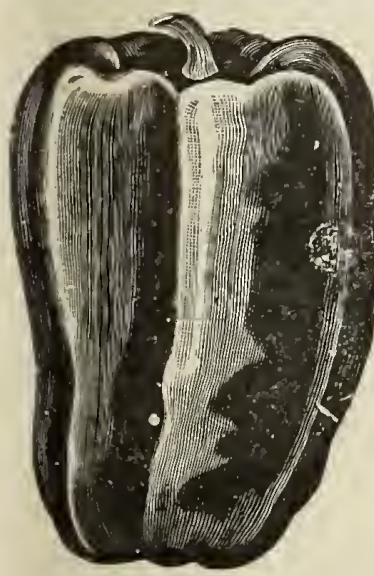

Ruby King. apart iu the rows. The ground should be made very rich, either by high mauuring before plants are transplanted, or by the liberal a pplication of guauo or liquid manure afterwards.

Ruby King. The peppers often obtain a very large size. When ripe they are bright ruby red. Price per pkt., 5c.; per oz., 20c.; per lb., \$2.00.

Large Bell or Bull Nose. An early variety, fruit tliree to five inches long, flesh thick, sweet aud mild. Price per pkt., 5c.; per oz., 2oc.; per $1 \mathrm{~b} ., \$ 2.00$.

Squash or Tomato=Shaped. This kiud is flat like a tomato, and is generally used for pickling; flesl thick, acrid and pungent. Price per pkt., 5c.; per oz., 25c.; per 1b., \$2.50.

Golden Queen. Very large, bright golden yellow, mild iu flavor. Price per pkt., 5c.; per oz., 2oc.; per 1b., $\$ 2.00$.

Celestial. The plant sets its fruit very early, and continues until frost. Up to the time they are fully ripe, they are of a delicate, creamy-yellow color, then changing to vivid scarlet. The peppers are very mild. Price per pkt., 5c.; per Oz., 25c; per $1 \mathrm{~b}$., 82.50 .

Red Cherry. A small, round variety, of dwarf growth, very piquant and quite ornamental. Price per pkt, 5 c.; per oz., $25 \mathrm{c}$; per $1 \mathrm{~b}$., 2.50 .

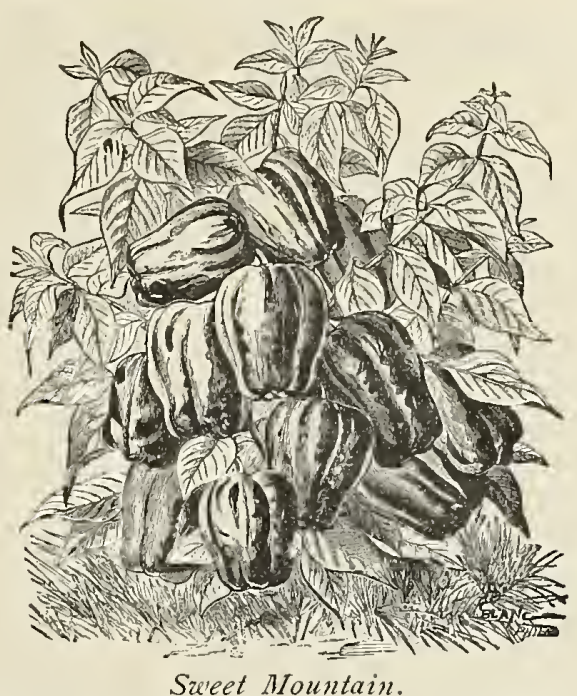

Sweet Mountain or Bell. A large, early variety, of mild flavor, rind thick and fleshy. Price per pkt., 5c.; per oz., 20c.; per 1b., \$2.0o.

Long Red Cayenne. Fruit bright coral red, grows three to four inches long and one and one-half inches in diameter. Price per pkt., 5c.; per oz., 25c.; per 1b., $\$ 2.50$.

Small Chili. Very piquaut and prolific. Price per pkt., 5c.; per oz., 30c.; per 1b., \$3.00.

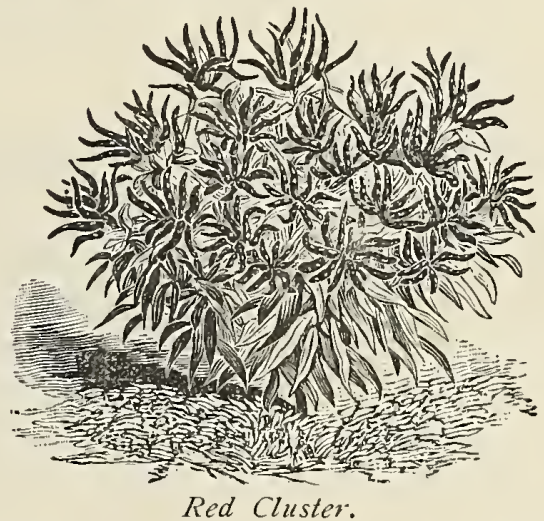

Red Cluster. Sma11, thiu peppers of a coral-red color, very hot and pungent. Price per pkt., 5c.; per oz., 25c.; per 1b., $\$ 2.50$.

\section{POTATOES.}

Kartoffeln-Patatas-Patate.

As prices of potatoes fluctuate according to supply and demand, it is impracticable to maintain any fixed price for seed sto:k tliat nıy in our jadgment seem throughout the plantiug seasou proper, when the catalogue goes to press-in Decellber-and quotations will be giveu on application.

Early Harvest. Very early, large smooth tubers, uearly white.

Polaris. Extra early, oblong in shape, with surface a little flattened, having few eyes.

Puritan. The skin and flesh are white, it cooks dry and floury, is very early.

Early Fortune. Extra early, resembling the Early Rose; very prolific. 


\section{POTATOES-Continued.}

Bovee. Fxtra early, long oval, smooth, good yielder. Irish Cobbler. Extra early, white, productive.

Early Michigan. Snowy white, fine grained, of delicate flavor.

Clark's Pride or Ensign Bagley. A new comer of great merit. (See Novelties, page 7.)

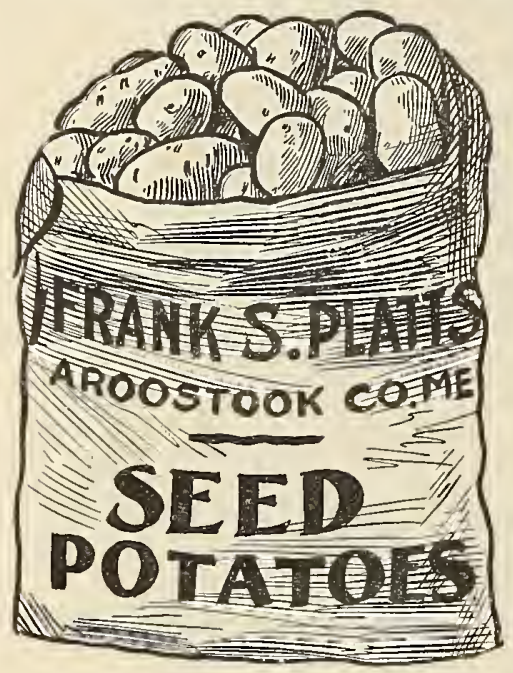

New $\mathbf{Q}$ ue e $n$. Ripens early, is of superb quality, and yields immense crops. Early Norther. Large size and early ripening give it especial value.

Early Rose. True stock, grown in Maine.

Beauty of $\mathrm{He}=$ bron. Like the Early Rose in shape, but lighter color; ripens early.

Carmen No. 1. Flesh is white, perfect in quality, and very dry.

Delaware. This is an oval oblong potato, white skin and flesh, large, or ahove the average.

Late Beauty of Hebron. Large oblong, good quality.

White Elephant. Very productive, excellent flavor and spleudid keeper.

Late Rose. True stock, grown in Maine.

Green Mountain. Vines strong and vigorous; tubes white, smooth and very large.

Great Divide. Long, white, heavy yielder; late.

Rural New Yorker No. 2. The tubers are of large size, with smooth, white skin.

Carmen No. 3. This is a late potato, white skin, growing uniformly large; a great yielder.

White Star. The tubers are large and oblong. The skin is white and covered with a russet netting.

Empire State. Medium late, white, oval, good quality and yielder.

Uncle Sam. Late, white, long oval tuber of large size.

Sir Walter Raleigh. This is a very large, late, white potato, square ended and a tremendous cropper. Also many other varieties not enumerated in this list.

\section{PUMPKIN.}

\section{Kürbis-Calabaza-Zucca.}

Plant about the middle of spring in manured hills, eight feet apart, and leave but two or three plants in a hill; or plant in spring with Indian corn. Avoid planting near other vines.

Sugar. A small, orange-colored pumpkin. It is very sweet and fine grained. Price per pkt., 5c., per oz., Ioc.; per 1b., 5oc.
Winter Crookneck. An old standard sort and good keeper, flesh close grained and flavor excellent. Price per pkt., 5 c.; per oz., Ioc.; per 1b., $50 c$.

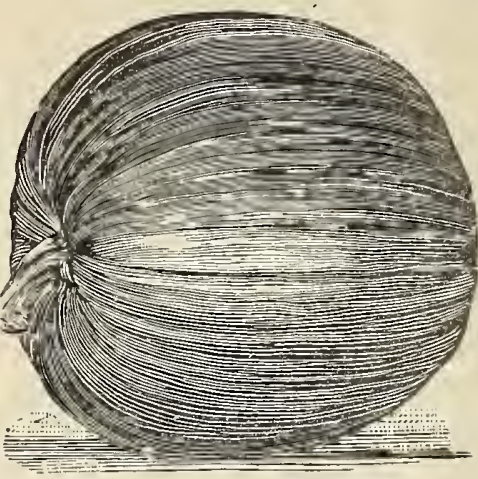

Connecticut Field. Improved Mam moth. Grows to an immense size, and has often been produced weighing $t w o$ hundred pounds. Price per pkt. 5 c.; per oz., Ioc. per 1b., 8oc.

Large Tours or rlammoth. A productive variety which grows to an immense size. Price per pkt., 5c.; per oz., Ioc.; per 1b. $50 \mathrm{~s}$.

King of Mlam moths, Jumbo or Potiron. One of the largest pumpkins; flesh bright yellow. Price per pkt., $5 \mathrm{c}$.; per oz., Ioc.; per lb., 6oc.

Large Cheese. A good cooking variety, cheese shape, creamy yellow color, flesh fine grained, and one of the best for pies. Price per pkt., 5c.; per oz, IOc.; per lb., 4oc.

Connecticut Field. The large, round, orange-yellow field variety; very prodnctive. Price per qt., $25 \mathrm{c}$. per oz., $5 \mathrm{c}$.; per $1 \mathrm{~b} .$, 3oc.

\section{RADISH.}

Rettig-Rabanos-Ravanelli.

\section{All Imported Seed,}

French Grown.

Sow early varieties in the spring as early as the ground can be worked, in drills ten inches apart, covering the seed half an inch deep; thin the plants to an inch apart in the row, as they are more tender and succulent when grown quickly. A rich, moist, sandy soil should be selected, and frequently watered in dry weather. For a succession, sow every two weeks till midsummer. 


\section{RADISH-Continued.}

Extra Early Scarlet Forcing Turnip. Matures in about twenty days. Bright red, globe shaped, small leaved. Price per pkt., 5c.; per oz., roc.; per 1b., 6oc.

Extra Early Scarlet Forcing (White Tipped.) It is a week earlier than Scarlet Turnip. Its shape is perfectly globular, with rich, deep scarlet top, blending into pure white at the bottom. It is fit to pull in three weeks from sowing. Price per pkt., 5 c; per oz., Ioc.; per 1b., 6oc.

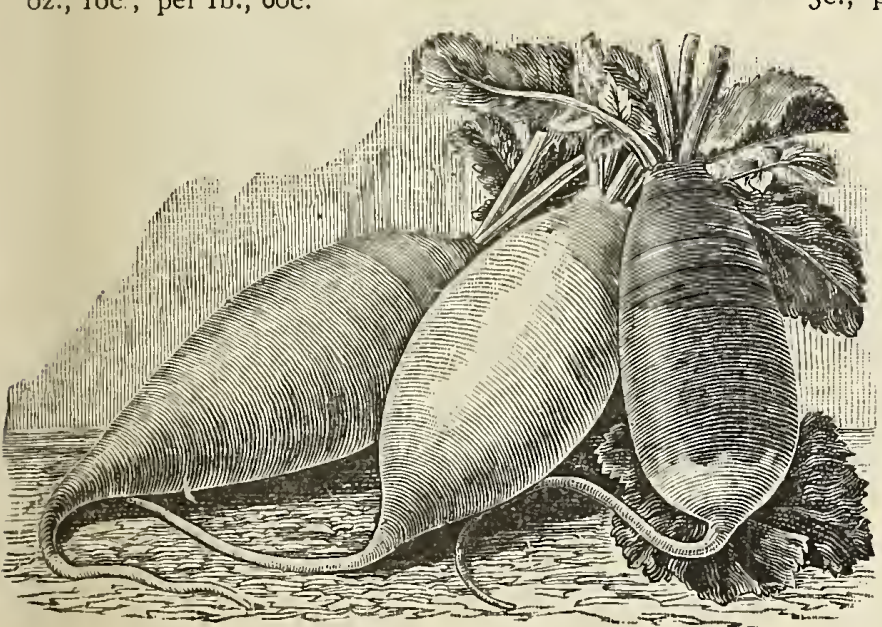
40c.

French Breakfast. A quick-growing, oral-shaped radish, light color and white tip. Price per pkt., 5c.; per oz., IOc. ; per 1b., 50c.

Early Olive - Shaped Scarlet. Very early, oblong in shape. Price per pkt, 5c.; per oz., Ioc.; per lb.,

White Strasburg. Pure white, firm and brittle; grows to a large size. Price per pkt., 5c.; per oz, Ioc.; per 1b., 6oc.

Chartier. It is an early summer variety; deep pi $n k$, blending into a pure, waxy white at the roots. Price per pkt., 5c.; per oz., IOc.; per lb., 6oc.

Wood's Early Frame. A long radish ; excellent for forcing. Price per pkt., 5c.; per oz., Ioc.; per $1 \mathrm{~b}$, , $40 \mathrm{c}$.

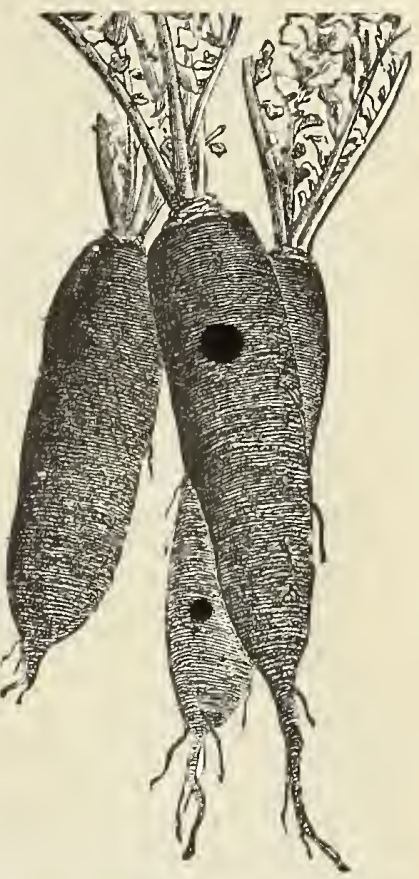

Black Spanish or Fall Radish.

Olive-Shaped Radishes.

Early Scarlet Globe. One of the best for forcing, per feclly round, bright cardinal color. Price per pkt. 5 c.; per oz., Ioc.; per 1b., 6oc.

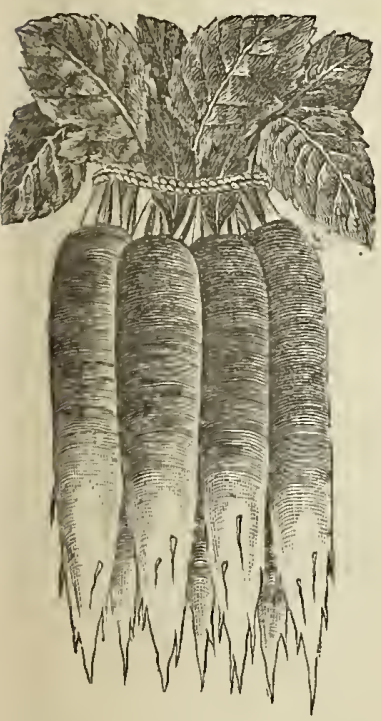

Chartier.
Early Scarlet: 'Turnip (White Tipped.) Early, fine grain and flavor; round, with white tip. Price per pkt.; $5 \mathrm{c}$.; per oz., Ioc.; per lb., 5oc.

Early Scarlet Turnip. Small, round, mild and crisp; a standard early sort. Price per pkt., 5c.: per oz., IOc.; per 1b., $40 \mathrm{Oc}$.

Deep Scarlet Turnip. Very early and a good forcing variety. Price per pkt., 5c.; per oz., Ioc.: per lb., $40 c$.

Triumph Radish. (See

Novelties, page 6.) Price per pkt., Ioc.; per oz, 3oc.

White Summer Turnip. Same shape as Scarlet Turnip, but purewhite. Price per pkt., 5 c.; per oz., Ioc.; per lb., 5oc. Gray Summer Turnip. Similar to the preceding, but darker skin. Price per pkt., 5c.; per oz., Ioc.; per 1b., 6oc.

New Icicle. (See Novelties, page 6.) Price per pkt., Ioc.; per oz., 20c.; per 1b., \$2.0o
WINTER RADISHES.

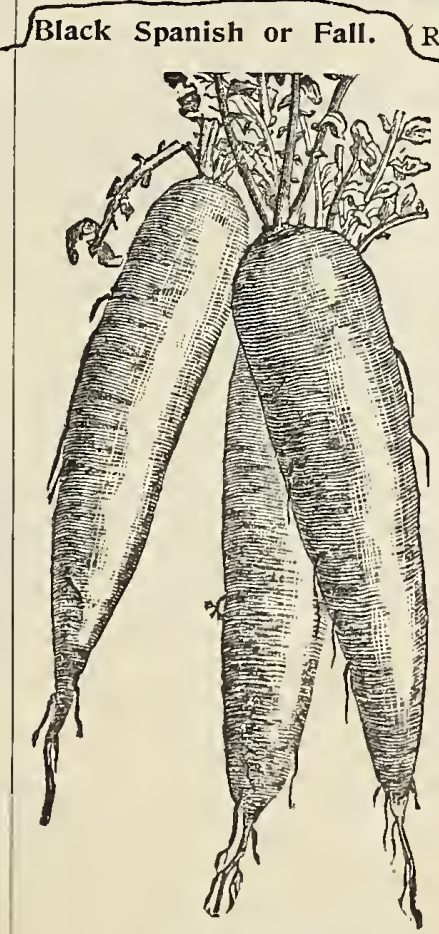

California Mammoth White.
Round. For winter use; solid. Price per pkt.; 5c.; per Oz., IOc.; per $1 \mathrm{~b} ., 50 c$.

Black Spanish or Fall Long. Like Long only in shape. Price Shan, with roc ; per lb., 5oc.

Early Long Scarlet Short Top. Bright red color, very small. Price per pkt., 5c.; per oz., roc.; per lb., $40 c$.

China Rose or Win= ter. Very fine for winter use; large and tender. Price per pkt., 5 c.; per oz., Ioc.; per lb., 6oc.

\section{California Mammoth} White. A winter sort, grows eight to ten inches long, and keeps well. Price per pkt., 5c.; per oz., IOc.; per lb., $60 c$. 


\section{RAPE--English.}

Dwarf Essex, forage plant of great value. Of rapid and luxuriant growth, attaining a height of two or three feet. It may be sown throughout the season, and in a few weeks from sowing, stock can be turned in on it. For broadcasting, sow ten pounds to the acre; in drills, five pounds.

Used also for greens and salad. Price per 1b., I2c.; ten pounds for \$I.oo.

\section{Salsify or Oyster Plant.} Hafererrzel-Ostion Vegetal-Sassefrica.

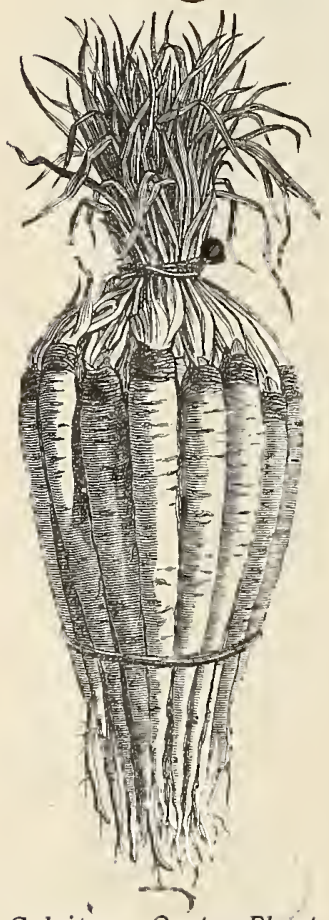

Salsity or Oyster Plant.
Sow in early spring, in light, rich soil, in drills fourteen inches apart; thin the plants to three inches in the row. The roots will be ready for use in October, and, like the parsnip, improve by remaining in the ground through the winter.

$M$ am moth Sandwich Island. Roots grow long, large, smooth and white. Price per pkt., 5c.; per oz., Ioc.; per lb., \$I.oo.

Long White French. The standard variety. Price per pkt., 5c.; per oz., Ioc ; per 1b., \$I.oo.

\section{SPINACH.}

Spinat-Espinaca-Spinaci.

Culture. For the summer crop, sow early in March, and at intervals of a fortnight, till the middle of July, in quantities according to the demand. The round-seeded varieties are the best for summer use. The winter crop should be sown from the middle of August to the beginuing of September. It should always be sown in drills from one to two inches deep, and frotn twelve to eighteen inches apart, scattering the seed thinly and covering them with the finest of soil. Protect the winter crops on the approach of severe frosts.

Norfork Savoy Leaved. (Bloomsdale.) It is very productive and the hardiest of all the smooth-leaved varieties. Price per pkt., 5c.; per oz., Ioc.; per 1b., 3oc.; ten pounds and over, at $25 \mathrm{c}$.

Victoria. It is a very large, crumpled-leaved, dark green plant, spreading well on the ground. Price per pkt., 5c.; per oz., Ioc.; per 1b., 40c.; ten pounds and over, at $35 \mathrm{c}$.

Improved Large Round Leaf." A variety with very thick leaves. Price per pkt., 5c.; per oz., Ioc.; per 1b., 3oc.; ten pounds and over, at $25 \mathrm{c}$.
Giant Thick Leaf or Round Viroflay. Similar to the lettuce-leaved, but much larger in habit of growth. Price per pkt., 5c.; per oz., Ioc.; per 1b., 35c.; ten pounds and over, at $30 c$.

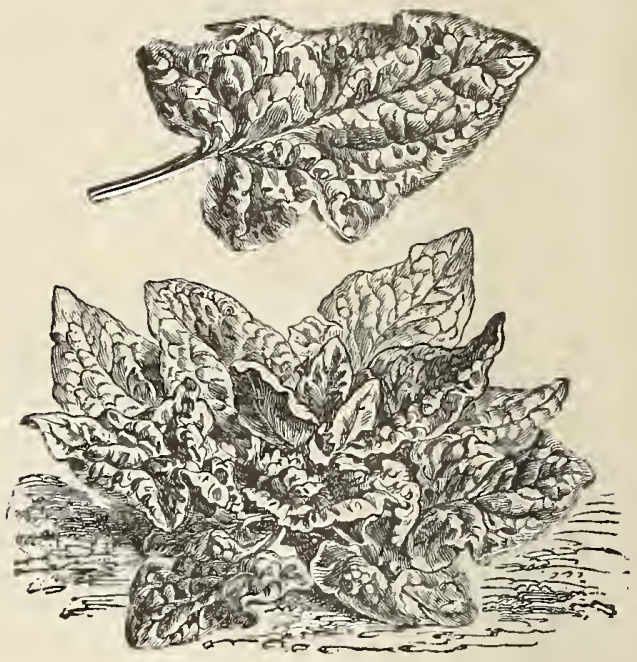

Giant Thick Leaf or Round Viroflay.

Long Standing. A fine round-leaved summer variety, slow to run up its seed stalks. Price per pkt., 5c.; per oz., Ioc.; per 1b., 35c.; ten pounds and over, at $30 \mathrm{c}$.

Prickly or Fall. The hardiest variety; leaves thick and triangular in form. Price per pkt., $5 \mathrm{c}$; ; per oz., IOc.; per $1 \mathrm{~b} \cdot$, 30c.; ten pounds and over, at $25 \mathrm{c}$.

\section{SQUASH.}

Speise Kürbiss-Calabaza-Zucche.

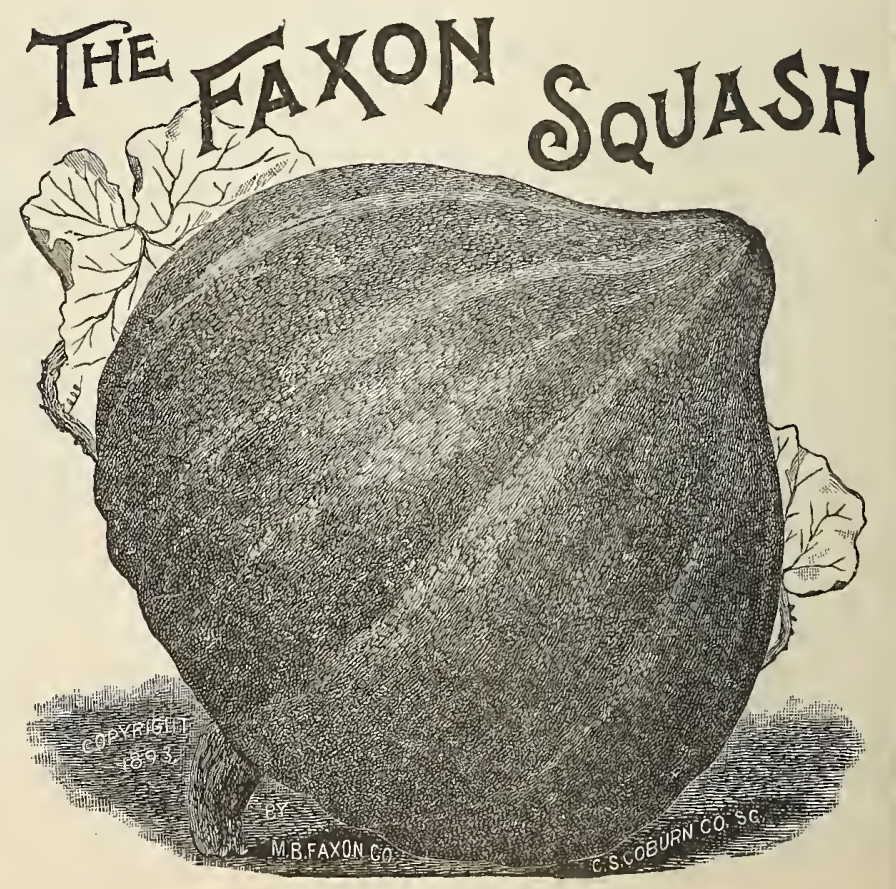




\section{SQUASH-Continued.}

The squash is a very tender vine, and so sensitive to the cold that it cannot with safety be planted out until the weather becomes warm and settled. Plant in hills ten feet apart for running varieties; five feet for bush sorts; working some fine rich manure into each hill. Sprinkle liberally with plaster, wood ashes, or air-slacked lime, in the early stages of
Pineapple. It is very peculiar and distinctive in shape; the skin is a cream white. Good both for summer and winter. Price per pkt., 5c.; per oz., roc.; per 1b., 6oc.

Cocoanut. This is very prolific, producing from six to twelve on a vine; the flesh fine grained and solid. Price per pkt., 5c.; per oz., Ioc.; per 1b., 75c.

Boston Marrow. A superior fall squash, of rich orange color and very productive. Price per pkt., 5c.; per oz., roc.; per lb., 4oc.

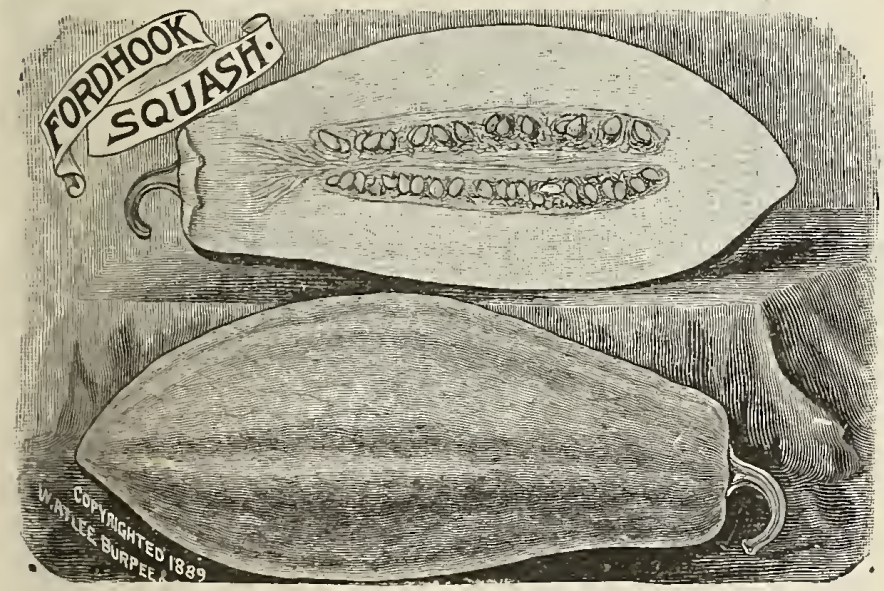

Hubbard. Dark green, hard shelled variety ; flesh fine grained, dry and of good flavor. Price per pkt., 5c.; per oz., Ioc.; per 1b., $60 c$.

Warted Hubbard. Similar shape and color to the original Hubbard Squash, but developing at least one-third to one-half larger fruits in great abundance, with hard, roughly warted surface. Quality of flesh is equal to any of its class. Price per pkt., 5c.; per oz., Ioc.; per 1b., 75c.

New Red or Goldtn Hubbard. A reproduction of the old Green Hubbard except in color, which is a bright, deep orange yellow. Flesh, deep golden yellow, much richer in color than Hubbard; fine grain, cooks very dry, and is of excellent flavor. Its keeping qualities and productiveness are unexcelled. Price per pkt., 5c.; per oz., roc.; per 1b., 8oc.

growth. Cultivate until runners are well started.

The Faxon. Medium size, winter variety ; orange flesh of fine quality. Price per pkt., 5c.; per oz., IOc.; per lb., 6oc.

Fordhook. Of a light yellow color outside, and straw yellow within. The flesh is sweet and fine grained. Price per pkt., 5c.; per oz., Ioc.; per 1b., 6oc.

Yellow Bush Scallop Summer. One of the earliest; grows flat, with scallop edges, and is a good market sort. Price per pkt., 5c.; per oz., Ioc.; per 1b., 5oc.

White Bush Scallop. Like the above in everything except color, which is creamy white. Price per pkt., 5c.; per oz., Ioc.; per 1b., 5oc.

Early Summer Crookneck Bush. Early and productive; the best kind for summer use. Price per pkt., 5c.; per oz. Ioc.; per $1 \mathrm{~b} ., 50 c$.

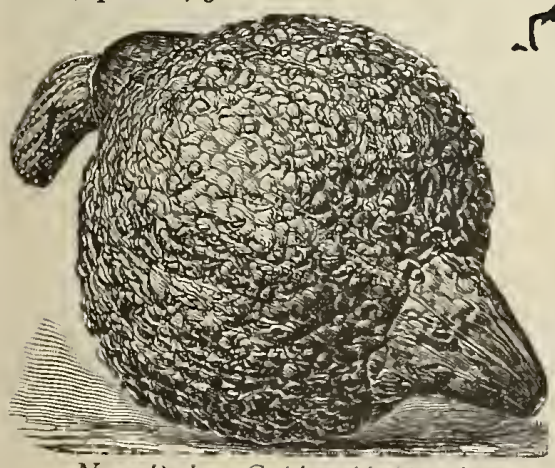

New Ked or Golden Huboard.

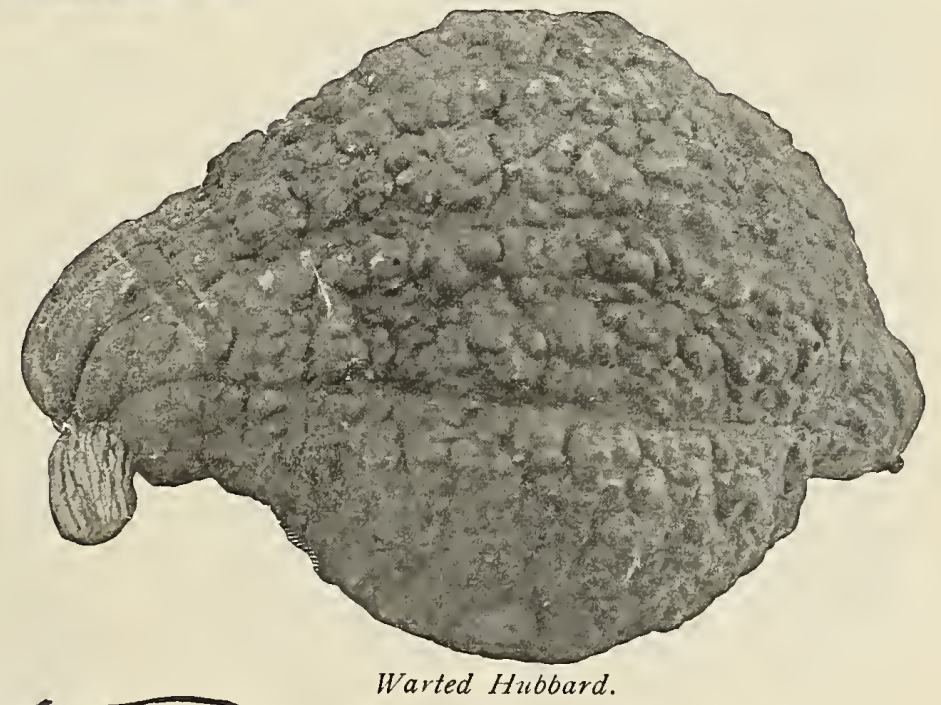

Giant Crookneck. Summer. Grows about double the size of the Early Summer laoknedk and is about as early. Price per pkt., 5c.; per oz., Ioc.; per 1b., 50c.

Delicata. (See Novelties, page 7 ) Price per pkt., 5c.; per oz., Ioc.; per 1b., 6oc.

Perfect Gem. From four to six inches in diameter, of a creamy yellow color, slightly ribbed, thin, smooth skin, fine grained and sweet. Price per pkt., 5c.; per oz., roc.; per 1b., 6oc.

Cocozella. (See Novelties, page 7.) Price per pkt., 5c.; per oz., Iuc.; per 1b., 9oc.

Winter Crookneck. Flesh close grained, sweet and fine flavored. Price per pkt., 5c.; per oz., IOc.; per 1b., 5oc.

Pike's Peak or Sibley. Fine grain and wonderfully productive. The flesh is thick and rich colored, shell hard and flinty. Price per pkt., 5c.; per oz., IOc.; per 1b., $60 \mathrm{c}$. 


\section{SQUASH-continued.}

Golden Bronze. (See Novelties, page 7.) Price per pkt., 5c.; per oz., I5c.; per 1b., \$1.5o.

Essex Hybrid. This is a cross between the Turban and the Hubbard, having the shape of the former and the shell of the !atter. Price per pkt., 5c.; per oz., Ioc.; per 1b., $65 \mathrm{c}$.

\section{TOBACGO.}

Sow the seed in frames the latter part of March, or iffopen ground when the soil has become settled and warm. Keep well watered, and when the plants are two inches high they may be transplanted in rows three feet apart each way. Tobacco requires a very rich, light, mellow soil.

Connecticut Seed Leaf. The popular kind cultivated in this vicinity, and produces a very heavy crop of fine, broad leaves. Price per pkt., 5c.; per oz, 2oc.; per 1b., \$2.oo.

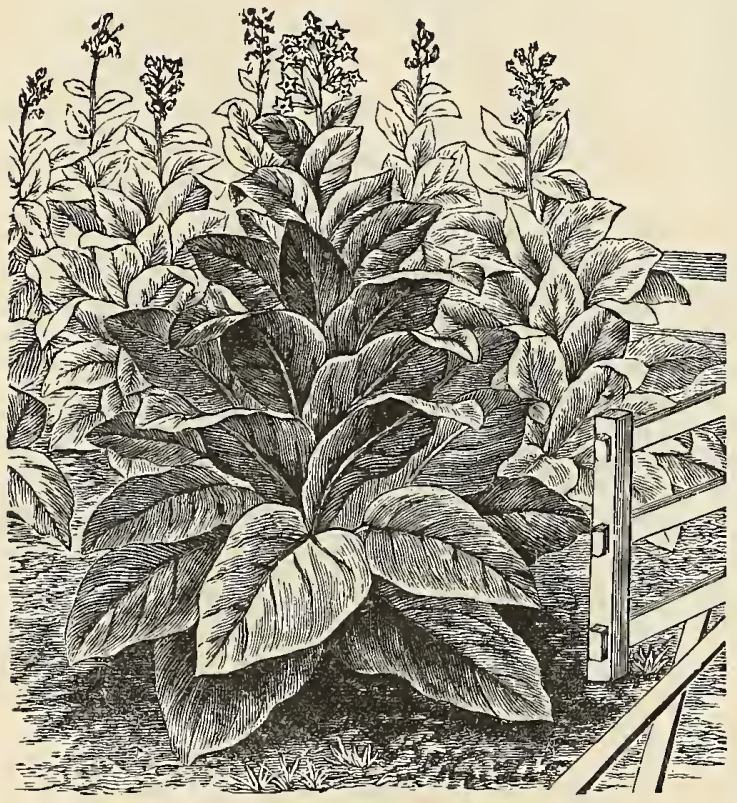

Tobacco.

Havana. An excellent variety; leaves narrow, long and pointed. Price per pkt., 5c.; per oz., 20c.; per 1b., $\$ 2.50$.

\section{TOMATO.}

\section{Liebesapfel--7omates-Pomodoru.}

To obtain fruit very early, sow the seeds in greenhouse during February or March, or in hotbed when season has sufficiently advanced. In about five weeks plants should be transplanted to another hotbed, until about the middle of May; they may be put into the ground in hills about four feet apart each way. The richer the soil the ranker will be the growth of vines, but an ordinary, warm, light soil, with fine, wellrotted manure in the hill, and a sunny location, will produce the more handsome and plentiful fruit.

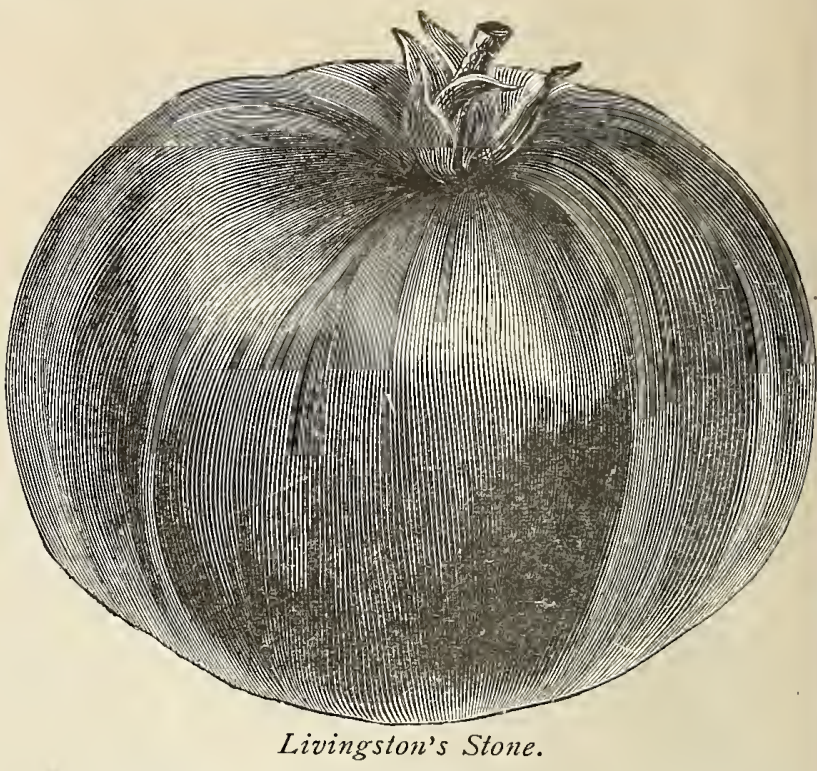

Livingston's Stone. Bright scarlet, very smooth, ripening evenly to the stem; solid and firm fleshed. Price per pkt.. 5c.; per oz., 25c.; per 1b., $\$ 2.50$.

Dwarf Champion. It stands up well, having a stiff bush stem. The crop ripens early and evenly. It is a good cropper, smooth, medium in size; in color, purple, tinged with crimson. Price per pkt., 5c.; per oz., 2oc.; per 1b., \$2.oo.

The Aristocrat. An exceedingly dwarf variety; the color of the fruit is fine rich, glossy red. It is solid and smooth, and in size from medium to large. Valuable for forcing. Price per pkt., 5c.; per oz., 25c.; per $1 \mathrm{~b}, \$ 2.50$.

ind

Fordhook. Extra early, purple tinged ; fine, snooth, solid; medium size. Price per pkt., 5c.; per oz., 20c.; per 1b., \$2.oo.

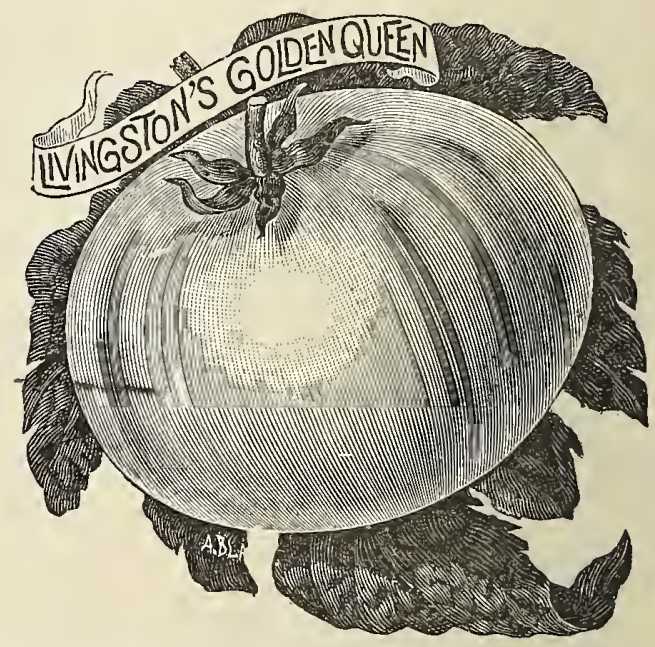

Golden Queen. A good yellow sort, of first quality. It is solid, very smooth, large in size; ripens early. Price per pkt., 5c.; per oz., 3oc.; per 1b.. \$3.0o.

Atlantic Prize. Very early; smooth, bright red and solid. Price per pkt., 5c.; per oz., 20c.; per 1b., $\$ 1.75$.

Livingston's “Magnus.” (See Novelties, page 8.) -Price per pkt., Ioc.; per oz., 5oc. 


\section{TOMATO-Continued.}

Livingston's Beauty. Dark red, large size, smooth and fair. Price per pkt., 5c.; per oz., 2oc.; per lb., $\$ 2$ co.

Essex Hybrid. Color purplish red, ripening throughout with great uuiformity. Price per pkt, 5c.; per oz., 20c.; per 1b., \$1.75.

Buckeye state. Very solid; color, deep purplish red, and very large in size. Price per pkt., 5c.; per oz., 20c.; per 1 b. $\$ 2$.0o.

Mikado. The tomatoes are perfectly solid, generally smooth, but somewhat irregular. The color is purplish red, foliage distinct; coarse leaved. Price per pkt., 5c.; per oz., 25c.; per lb., \$2.50.

Ponderosa. This excels in size, weight and solidity. Its color is light crimson, and almost seedless. Price per pkt., 5c; per oz., 4oc.; per 1b., $\$ 350$.

Acme. Very prolific; iu color a purplish crimson; very smootli and solid. Price per pkt., 5c.; peroz., 20c.; per 1b., \$2.0o.

Livingston's Favorite. Is large and smooth, bright red. Does not crack after ripening. It has very few seeds and is very productive. Price per pkt., 5c.; per oz., 20c.; per lb., $\$ 2.00$.

Trophy. This fine tomato is large in size, bright red, solid, smooth; a great yielder. Price per pkt., 5c.; per oz., 20c.; per 1b., $\$ 1.75$.

Honor Bright. Its chief peculiarities are its solidity, and changes of color the fruit undergoes during development; first it is light green, then an attractive waxy white, then lemon, changing to red. It is one of the longest keeping varieties. Price per pkt., 5c.; per oz., 25c.; per llu., $\$ 2.50$.

Peach. Resembles a peach in shape, size and color; beautifully blended and covered with a delicate bloom like a peacl. Price per pkt., 5c.; per oz., 20c.; per lb., $\$ 2.00$.

Yellow Pear. Pear sliaped and used for pickling or preserving. Price per pkt., 5c.; per oz., 25c.; per ib., $\$ 2.50$.

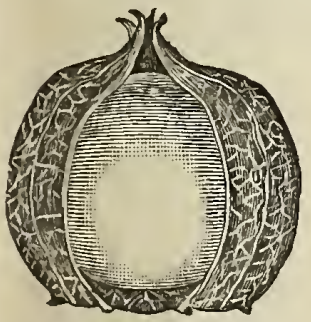

Strawberry or Ground Cher. ry. This, unlike other varieties, grows in a husk or pod, and may be kept all winter if the husks are not removed. The fruit is yellow and has a very sweet, pleasant flavor; may be eatell raw, but is geuerally used for preserves. Price per pkt., 5c.; per oz., 3oc.; per lb. $\$ 3.00$.

Strazubery Tomato.

Red Cherry. A small, round, red toniato; size and shape like a clierry. Price per pkt., 5c.; per oz., 25c.; per 1b , $\$ 2.50$.

\section{TURNIP.}

$R \ddot{i b} e-N a b o-R a p e$.

For early use, sow as soon as the ground can be worked in the spring, in drills fon rteen inches apart, covering but slightly, except in dry weatler. Tlie soil should be liglit and, if possible, new. Manure with plaster, ashes or pliosphate. Thin the early varieties to six inclies apart, and the Ruta Bagas from eight to ten inches. For fall and winter use, the early kinds should be sown in July and August, and the Ruta Bagas through June. Hoe them a month after sowing.
Scarlet Kashmyr. (See Novelties, page 7.) Price per pkt., 5c.; per oz., $10 \mathrm{c}$; per lb., 75c.

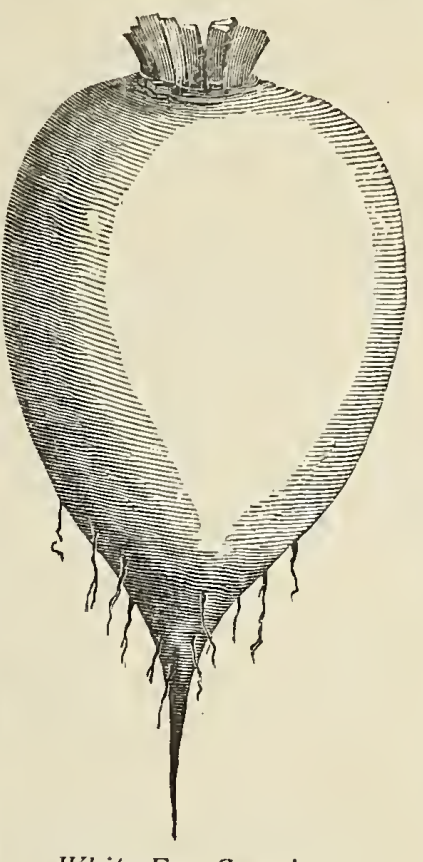

White Egg Turnip.
Wh it e Eg g. (See Novelties, page 8.) It is an early, very smooth, fine, hard grained, white oval turnip, as its name indicates, and unsurpassed for table use. Price per pkt., 5c.; per oz., Ioc.; per 1b., 4oc.

Early White Flat Dutch. A fine garden variety, differing from White Strap Ireaf only in the sliape of its leaf, this growing broader and rough edged. Price per pkt., 5c.; per oz., Ioc.; per 1b., 35c.

Early White Strap Leaf. A good flat turnip for early or late culture, and grows to a large size. Price per pkt., 5c.; per oz., Ioc.; per lb., $35 \mathrm{c}$.

Long White or Cow Horn. A long, quick. growing turnip, fine grained, tender and sweet. Price per pkt., 5c.; per oz., Ioc.; per 1b., 4oc.

Red Top White Globe. It is a white turnip with a red top. Price per pkt, 5c.; per oz., Ioc.; per 1b., $35 \mathrm{c}$.

Golden Ball. Rapid grower, globe sliaped, and of a light yellow color. Price per pkt., 5c.; per oz., Ioc.; per lb., $35 \mathrm{c}$.

Yellow Stone. This is a round, yellow variety, and good keeper. Price per pkt., 5c.; per oz, Ioc.; per lb., 35c.

Yellow Globe. This grows to a large size, and is one of the best for general crop. Price per pkt., 5c.; per oz., Ioc., per lb., 35c.

Yellow A berdeen. (Green Top.) This is globe - shaped, and a good keeper. Price per pkt., 5c.; per oz., Ioc.; per 1b., 35c.

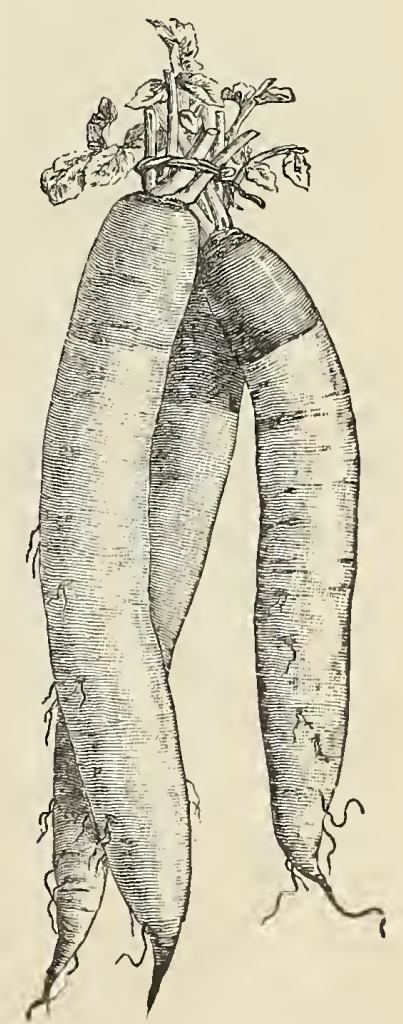

Long White or Cow HIorn. 


\section{TURRIP-Contimued.}

Early Red-Top Strap Leaf. This is similar to the preceding in all respects except the top of the turnip,

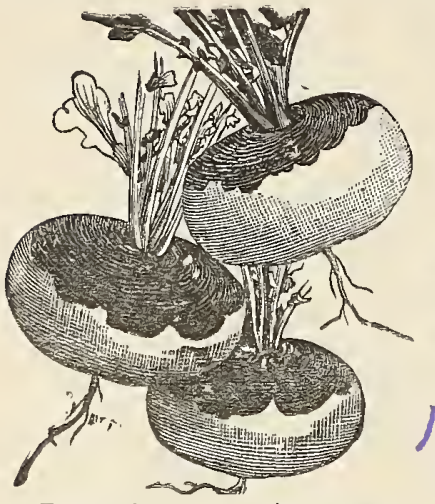
which is red or pur ple where exposed above ground. Price per pkt., $5 \mathrm{c}$.; per oz., IOc.; per 1b., 35c.

\section{Swedish or} Ruta-Baga

\section{Varieties.}

White French Sometimes called White Rock, on account of its firmness and solidity; flesh pure white, Early Red-lop Strap Leaf.

mild, very sweet, and good flavor. Price per pkt., 5c.; per oz., IOc.; per 1b., 40c.

Sweet German. White, sweet, and an excellent keeper; very hard and solid. Price per pkt., 5c.; per oz., IOc.; per lb., 4Oc.

Long Island Smooth Yellow. This is a fine-grained, hard, solid and sweet turnip; green top and good for table use or stock feeding; is very prolific and a good keeper. Price per pkt., 5c.; per oz., Ioc.; per lb., 40c.

Yellow French. An old variety; texture very firm and quality excellent; keeps through the winter and till late in the spring. Price per pkt., 5c.; per oz., IOc ; per 1b., 4Oc.

Laing's Improved Ruta Baga. One of the earliest Swedes; a desirable variety, of excellent quality. Price per pkt., 5c.; per oz., Ioc.; per lb., 40c.

American Purple=Top Ruta Baga. This is largely grown for feeding stock, but is very popular with the market gardeners for the table. Price per pkt., 5c.; per $\mathrm{Oz}$, IOc.; per 1b., 4 Oc.

Skirving's Rula Baga. This has a purple top; yellow, solid and fine grained. Price per pkt., 5c.; per oz., IOc.; per 1b., 40c.

\section{SWEET, OR POT AND MEDICINAL HERBS.}

A few pot herbs, or sweet herbs, as they are usually called, should have a place in every vegetable garden. A very small space in the garden will give all the herbs needed in any family. The culture is very simple, and the best way is to make a little seed bed in early spring, and set the plants out as soon as large enough in a bed. As a general rule, it is best to cut herbs when in flower, tie them up in small bunches and hang in the shade to dry. The following are a list of herbs most cultivated and prized:

Anise. Price per pkt., 5c.; per oz., Ioc.

Balm. Price per pkt., 5c.; per oz., $25 \mathrm{c}$.

Borage. Price per pkt., 5c.; per oz., I5c.; per 1b., $\$ 1$,oo. Caraway. Price per pkt., 5c.; per oz., Ioc.; per 1b., $50 \mathrm{c}$. Coriander. Price per pkt., 5c.; per oz., Ioc.; per $1 \mathrm{~b} ., 75 \mathrm{C}$.
Dill. Price per pkt., 5c.; per oz., IOc.; per 1b., $75 \mathrm{c}$. Horehound. Price per pkt., 5c.; per oz., $30 \mathrm{c}$.

Lavender. Price per pkt., 5c.; per oz., $20 \mathrm{c}$.

Rue. Price per pkt., 5c.; per oz., $20 c$.

Saffron. Price per pkt., 5c.; per oz., Ioc.; per 1b., \$I.oo.
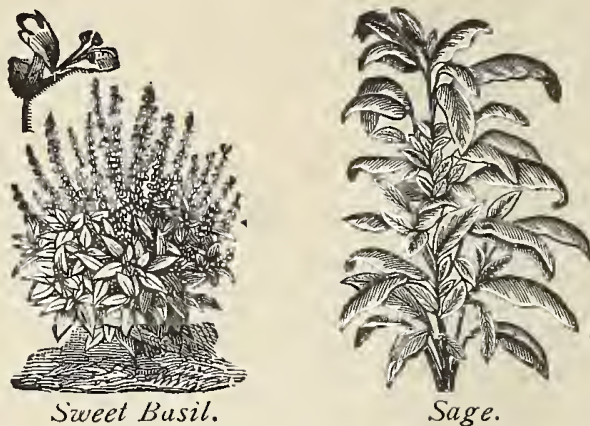

Sage, Broad Leaf English. Price per pkt., 5c.; per oz., I5c.; per 1b., \$I.50.

Sweet Basil. Price per pkt., 5c.; per oz., $20 \mathrm{c}$.

Sweet Fennel (Large). Price per pkt., 5c.; per oz., IOc.; per 1b., $75 \mathrm{c}$.

Sweet Marjoram. Price per pkt., 5c.; per oz., 20c.; per $1 \mathrm{~b} ., \$ 2,00$.

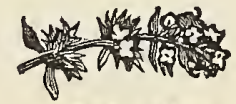

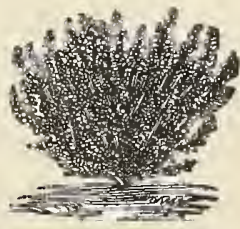

Thyme.

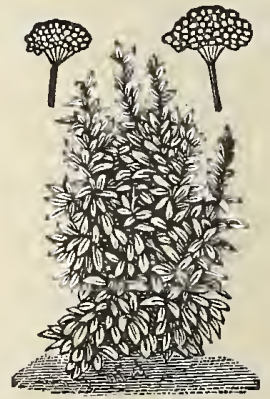

Sweet Masjoram.
Summer Savory. Price per pkt., 5c.; per oz., I5c.; per 1b., \$I.5O.

Thyme, Broad Leaf English. Price per pkt., per oz., $25 \mathrm{c}$; p per lb., \$2.50.

Wormwood. Price per pkt., 5c.; per oz., $25 \mathrm{c}$.

\section{HOME-GROWN HERBS.}

We frequently have calls for Pure, Home-Grown, Dried Herbs, and realize that the dirty, dry, hayed materials packed and pressed into small packages and sold for Pure, Fresh Herbs are not up to the requirements. They are often too old and ripe before cutting, and frequently stock that has been beaten by storms and become too much damaged and gritty to dispose of any other way. There is no good reason why every garden should not have its little patch of herbs from which the daily cuttings can be made, as wanted, all through the summer, and a nice quantity cut at the proper time and cured for winter use, preserving the fine green, fresh color, strength and aroma so desirable, but seldom secured in the regular stock pack. ages. Sage, Summer Savory, Thyme, Sweet Marjoram, etc., are so easily managed that it would seem hardly necessary to offer the suggestion, but as we have all these good things in our garden, hope others may appreciate them as we do. 


\section{FRANK S. PLATT'S}

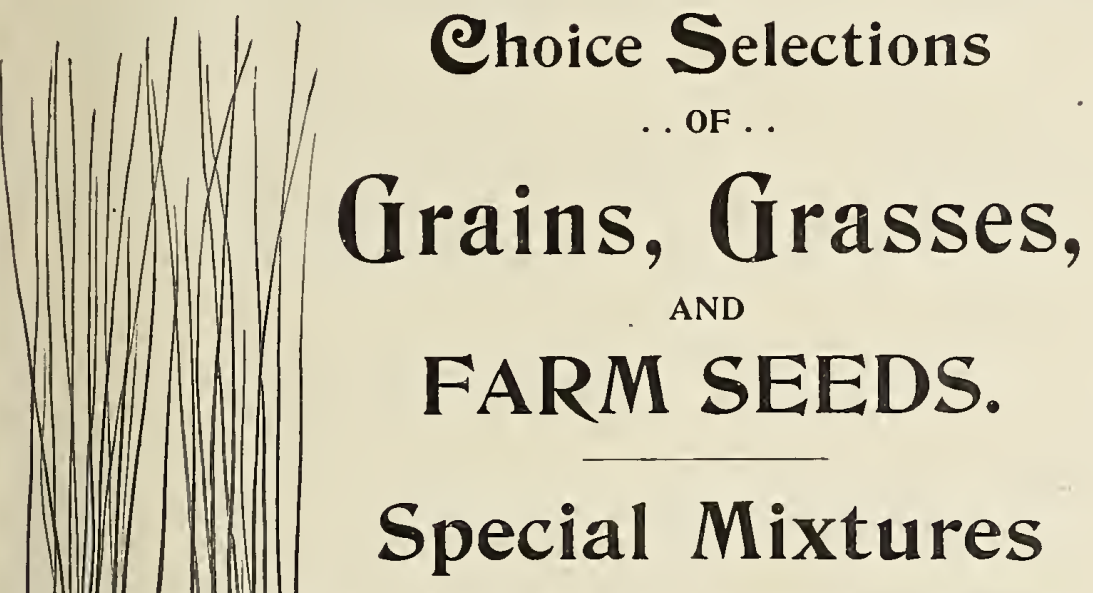

\section{For Lawns, Permanent Pastures or Hay are Unexcelled.}

\section{FARM SEEDS.}

Evergreen Broom Corn. Best for general cultivation; brush fine and long. Price per lb., 15c.; per Ioo lbs., $\$ 7.00$.

Early Amber Sugar Cane. Grows ten to twelve feet high. Price per lb., I5c.; per Ioo 1 bs., $\$ 6.00$.

Kaffir Corn. Will make a fine crop for forage if cut in early bloom, and the shoots that then follow will mature a full crop of seed and forage. Both grain and fodder are excellent, the whole stalk tender to the full maturity of seed. The grain is extremely valuable for feeding to poultry and will make a flour that is like wheat. Cultivated the same as our common Indian corn, requiring four or five pounds of seed per acre. Price per lb., I5c.; per Ioo lbs., \$6.0o.

Flax Seed. Price per 1b., 6c.; per Ioo lbs., $\$ 3.50$.

Sunflower. Mammoth Russian; large hears, grown for seeds. Price per 1b., Inc.; per Ioo lbs., \$5.00.

Hemp. Price per 1b., 6c.; per Ioo 1bs., $\$ 5.00$.

Celery Seed. For flavoring. Price per oz., 5c,; per 1b., 40c.; per I00 1bs., $\$ 25.00$.

Spring Vetches or Tares. A species of the pea, grown extensively in England and to a considerable extent in Canada for stock. Culture same as field peas, two busnels per acre. Price per qt., I5c.; per bu., $\$ 3.50$

Canada Field Peas. See page 3I. Price per qt., roc.; per bu., $\$ 1.50$.

Southern Cow Peas. A valuable crop for ploughing under, and especially desirable for light lands. Sow about one and one-half bushels per acre.

Clay, \$1.75 per bu. Black, \$r.75 per bu.

Whippoor will, $\$ 2.00$ per bu. Black Eye, $\$ 2.50$ per bu.

Soja Bean or German Coffee Bean. Its principal value consists in its uses as a forage crop-for feeding green-and for ploughing in as a fertilizer. Price per bu., \$2.00.

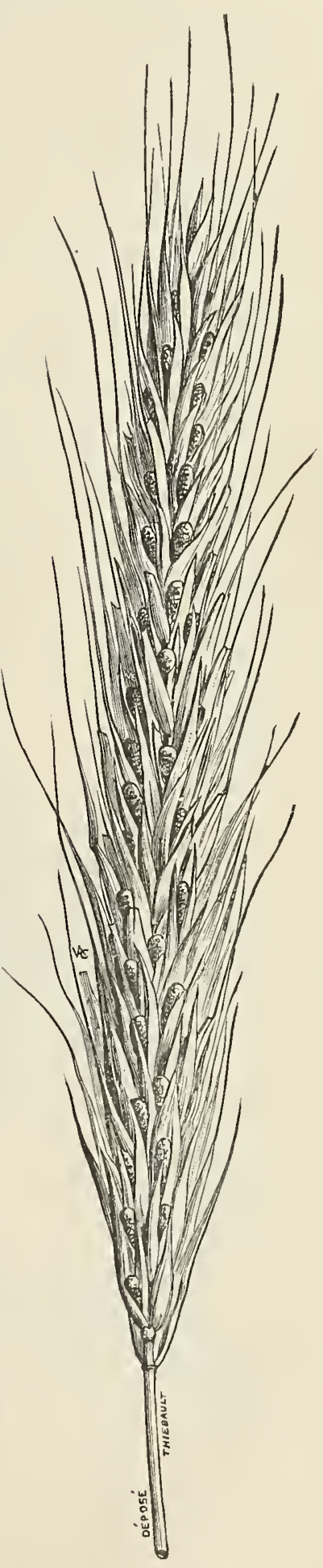

White Rye. 


\section{GRAIN. SPRING WHEAT.}

Saskatchewan Fife. It is ten days earlier than the common Fife, straw growing about a foot taller, standing stiff and strong. Price per bu., \$1.50.

China Spring. A white chaff, bearded, standard variety. Price per bu., $\$$ I.5O.

White Russian Spring. A light colored variety of red wheat. An enormous cropper, and bears long heads. Price per bu., \$1.50.

\section{WINTER WHEAT.}

Golden Straw. The straw is very strong and stands up well until the grain is matured. The heads are broad, beardless and of good length, with the grains set close together. The chaff is of a golden reddish tint, grains large and very heavy. Is a very heavy stooler; in fact, is a very desirable variety in every respect. Price per bu., \$1.50.

Hamilton Red. A new variety, being first heard from a year ago in Livingston County, N. Y. This is the ideal wheat for farmers wishing a red colored wheat and heavy yielder. Heads are heavily hearded, compact and of good length; color of chaff, a dark bronze; grains large, very heavy and set closely together. Straw stiff, of medium height, and heavy stooling proclivities. Price per bu., \$I.50.

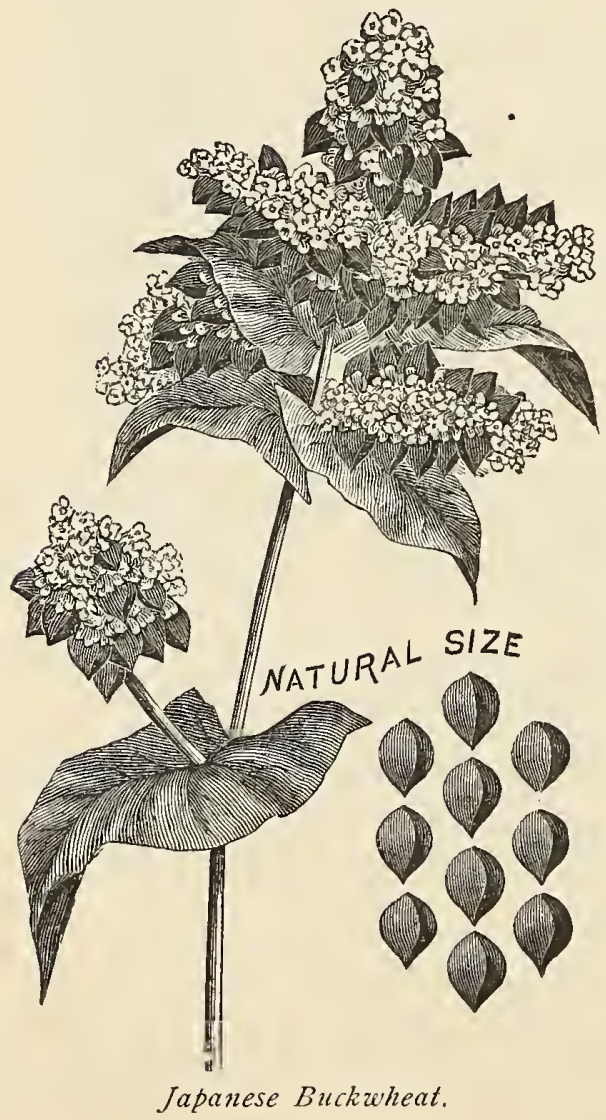

\section{WINTER WHEAT-Continued.}

Red Mediterranean. This is one of the most desirable kinds for this locality; heads bearded, well filled, and ripens early. Price per bu., $\$$ I.50.

\section{BUCKWHEAT.}

Japanese. The straw is heavier, it branches more, and does not need to be sown as thickly as the other kinds. Price per bu., \$1.25.

Silver Hull. A heavy yielder; the berry is of a light silvery-gray color. Price per bu., $\$ \mathrm{r} .5 \mathrm{o}$.

Common Gray. An old and well-known variety. Price per bu., $\$$ r.oo.

\section{SPRING BARLEY.}

$$
\text { Orzo. }
$$

Barley. (For cutting green.) Dairymen who sow barley with peas early in spring obtain a nuost nutritious and milk-producing food. It may profitably be sown late in summer also, as it will stand considerable frost and furnishes a rich pasture clear into November. Price per bu., $\$$ r.oo.

Imperial. A six-rowed productive variety; straw tall and stiff, with long, full heads; stools freely. Price per bu., \$r.oo.

\section{RYE.}

Choice White. Light colored grain, large kernel, and makes superior flour. Price per bu., $\$$ r.oo.

Spring. It is an excellent catch-crop where winter grain has been killed out, making good straw and fair yield. Price per bu., $\$$ I.25.

Winter. This is the ordinary variety sown in the fall, but my seed is from choice selected stock. Price per bu., $85 \mathrm{c}$.

\section{DATS. \\ Avene o Biada.}

Linc oll1. Enormously productive; arly, stiff straw, thin hull and heavy meated, and as near rust proof as any. Price per bu., 8oc.

Welcome. A heavy barley oat, with stiff straw. Price per bu., 8oc.

Choice White. Price per bu., 5oc.

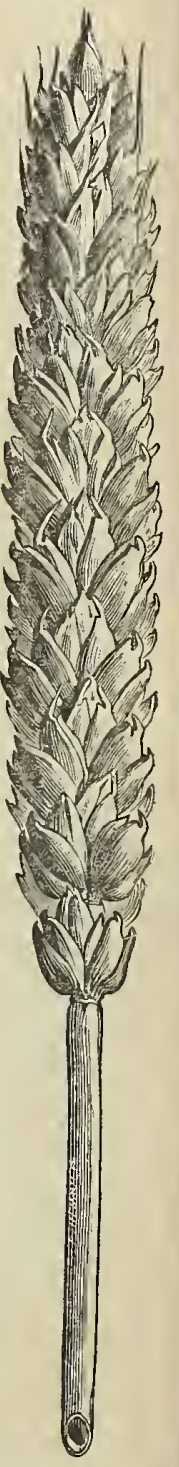

Golden Straw Wheat.
Also other improved sorts for spring sowing not here enumerated. 


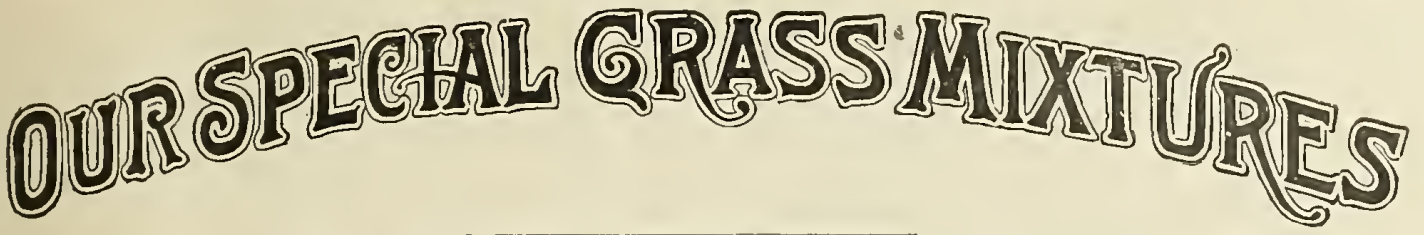

\section{GRASS SEED FOR LAWNS, ETG.}

In laying out a piece of ground for a lawn, care should be exercised to obtain the proper grade and slope, and perfect the general plan of the grounds before attenipting to sow any seed at all. After the correct grade has been obtained, and the surface sufficiently plowed or spaded, it should be thoroughly harrowed to pulverize the lnmps, and so left, that there may be at least from five to ten inches of good, rich soil over the whole surface. Then all the roots and loose stones should be removed, and the surface bushed or raked down perfectly smooth and in a suitable condition for successful germination and growth of the fine seed which is used for seeding. The preparation of most lawn seeds is composed of the finest kind of grasses, and for that reason should be sown much thicker than the coarse sorts that are used in field seeding. After sowing the seed, rake or harrow the surface liglitly, and then roll thoroughly, to smooth off, and leave in good condition.

\section{PLATT'S EVERGREEN LAWN MIXTURE.}

This mixture is the finest in quality that we prepare for general situations. It is composed of a jndicious combination of the short fine-growing varieties that have proved most valuable. It is perfectly adapted to the soil and climate of New Haven, as evidenced by the many beautiful lawns and parks that have been developed and seeded with "Platt's Evergreen Lawn Mixture" for twenty-five years. Price per qt., 20c.; per bu., $\$ 4 \cdot 00$.

\section{LAWN GRASS SEED. FINE MIXTURE.}

This is composed entirely of indigenous grasses of the finer grades, and in sufficient variety to produce throughout the spring, summer and autumn very satisfactory results. Price per qt., I5c.; per bu., $\$ 3.00$.
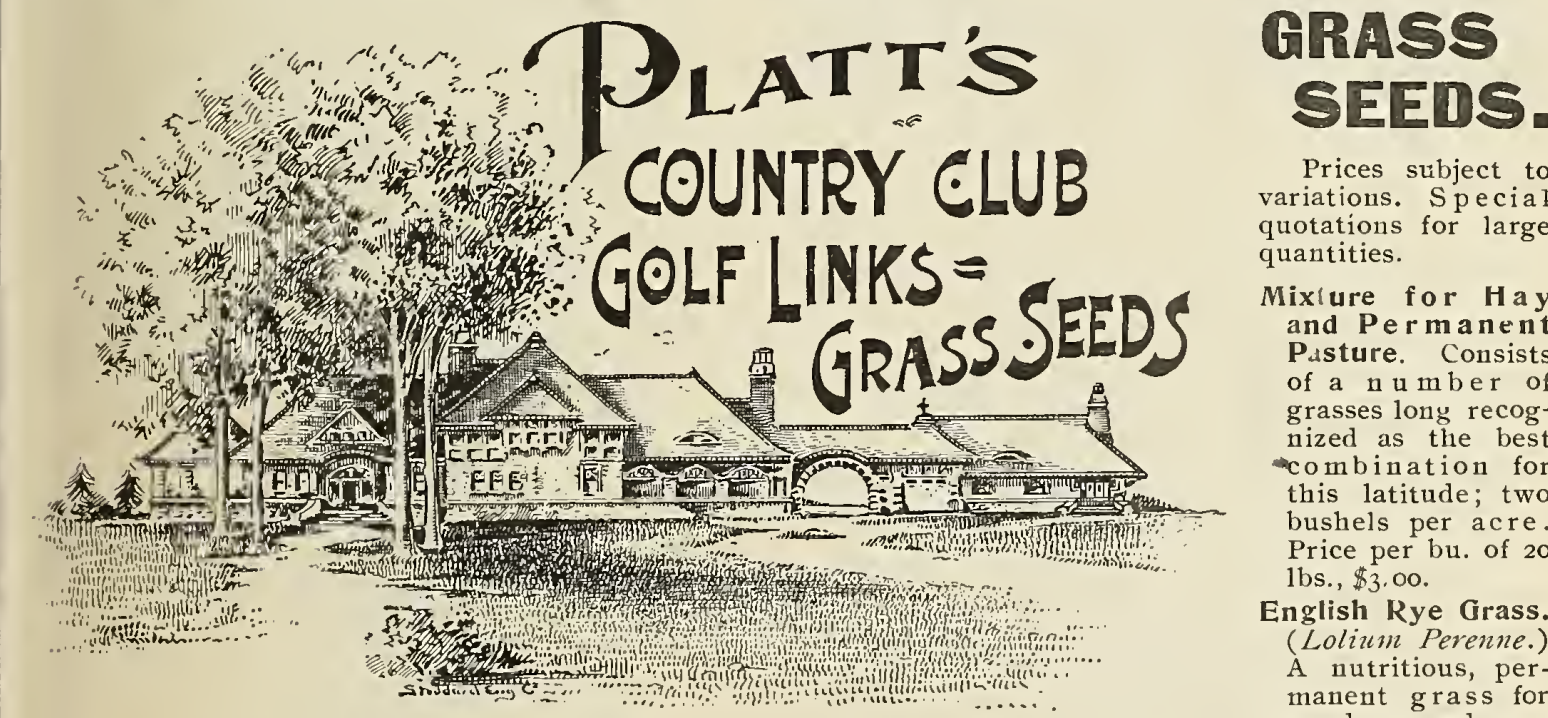

\section{PLATT'S "COUNTRY GLUB GOLF LINKS" GRASS SEED.}

A good article for large areas, or seeding the grounds about the new home. It is prepared with a well-balanced proportion of fibrous rooted grasses that alone are the perfect composition of a firm, tenacions turf. These varieties are not selected with especial reference to their height, as that feature is regulated by the lawn mower, but more particularly the turfforming properties and continuity of development, thus insuring a succession of ripening. Price per qt., 20c.; per bu., $\$ 4.00$. meadows and pasper qt., I5c; ; per bu., $\$ 1.5^{\circ}$; per 10o lbs., $\$ 10.00$.

Red Top Grass. (Agrostis Vulgaris) (In chaff.) A valuable native, pernianent grass, as a mixture in meadows, pastures or lawns, growing in almost any soil, moist or dry, and standing our hot climate. Price per qt., soc.; per bu., $\$ 1$ oo; per Ioo lbs. $\$ 7$ oo.

Red Top, Fancy Cleaned. Absolutely pure seed. Weight thirty-five pounds per bushel. Price per qt., 20c.; per bu.. \$5.50; per Ioolbs., $\$ 12.00$.

Rhode Island Bent Grass. (Agrostis Canina.) A valuable grass for lawns, sow three or four bushels to the acre for lawns; for pasture, one and one-half to three bushels. Price per qt., 20c.; per bu., $\$ 3.00$; per Ioo 1bs., \$18.00. 


\section{GRASS SEEDS - continued.}

Extra Clean Kentucky Blue Grass. (Poa Pratensis.)

Valuable for lawns when mixed with other varieties, retaining its verdure in the hottest weather. Per qt., 15c.; per bu., $\$ 1.50$; per Ioo lbs., $\$$ I0.00.

Meadow Fescue or English Blue Grass. (Festuca Pratensis.) A highly valuable species for permanent grass land. It does not, however, attain to its full productive power till the second or third year, when it far exceeds most other sorts in the quantity of its produce and nutritive matter. It is relished by stock, both in hay and pasture, and is one of the most desirable permanent grasses for general culture. Price per qt., I5c.; per bu., $\$ 2.00$; per Ioo 1bs. , \$12 oo.

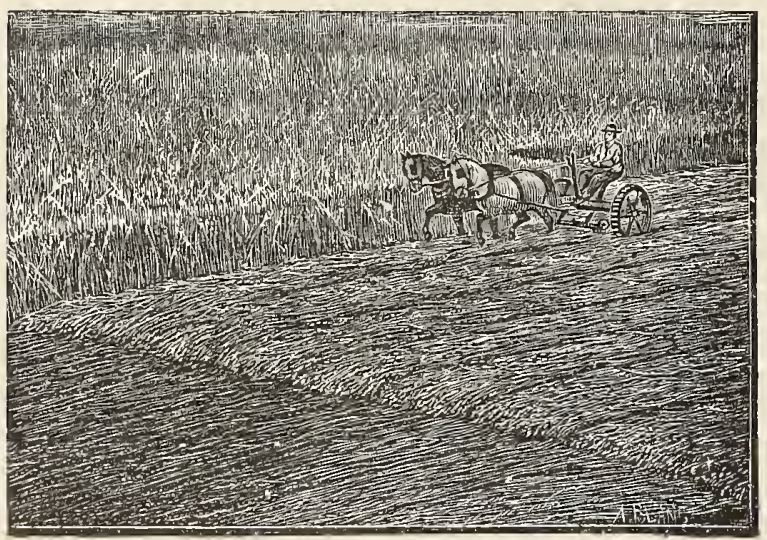

Mixture for Hay and Permanent Pasture.

Wood Meadow Grass. (Poa nemoratis.) It makes a very early growth in spring and is strongly recommended for pasture, thriving well under close feeding, also valuable in lawn mixture. Price per 1b., 35c.; per Ioo lbs., \$30.00.

Orchard Grass. (Dactytis Gtomerata) One of the most desirable pasture grasses for stock and for shady places. Price per qt., $I_{j}$ c., per bu., $\$ 1.75$; per IOo 1 bs., $\$$ I 2.00 .

Sheep's Fescue. (Festuca Ovina.) Grows freely in dry and open pastures. Its chief merit for sheep pasture is that it occupies land whicli better grasses refuse. Grows from six to ten inches high. Price per qt., 20c.; per bu., $\$ 2.50$; per Ioolbs., $\$ 15.00$.

Sweet Vernal Grass. (Anthroxanthum odoratum.) True perennial sweet vernal. Useful to mix with other grasses for pastures and lawns, on account of its early growth, and emitting an agreeable odor when cut for hay. Price per 1b., 75c.; roo lbs., $\$ 70.00$.

Timothy. (Phteum Pratense.) A well-known grass, and on some soils it will produce a larger crop than any other variety. We carry a larye stock of this seed, which is graded as "Prime," "Strictty Prime" and "Choice." "Prices on application.

\section{MILLETS.}

Hungarian Grass Millet. Early ; height two to three feet; abundaut foliage and small head; yields well on light soils. Price per qt., roc.; per bu., \$1.oo; per Ioo 1bs., $\$ 2.00$.
True Southern or Golden Millet. Equal in quality to any of the other millets and far superior in yield, growing from three to eight feet high, with abundant foliage, and terminating with large seed heads, formed by numerous panicles of small, round, bright golden yellow seeds. Price per qt., Ioc.; per bu., $\$ \mathrm{I} .50$; per I Oo 1 bs., $\$ 2.75$.

Japanese or Barn Yard. This is a new forage plant of great value, growing luxuriantly on most any soil and nnder indifferent conditions. My experiments with it, in a small way, have convinced me that it will produce a larger amount of hay than any of the other small stalk varieties. It will grow in seasons of extreme drought, and attain a height of six to twelve feet. Price per qt., 20c.; per bu., $\$ 5.00$; per Ioo lbs., \$10.00.

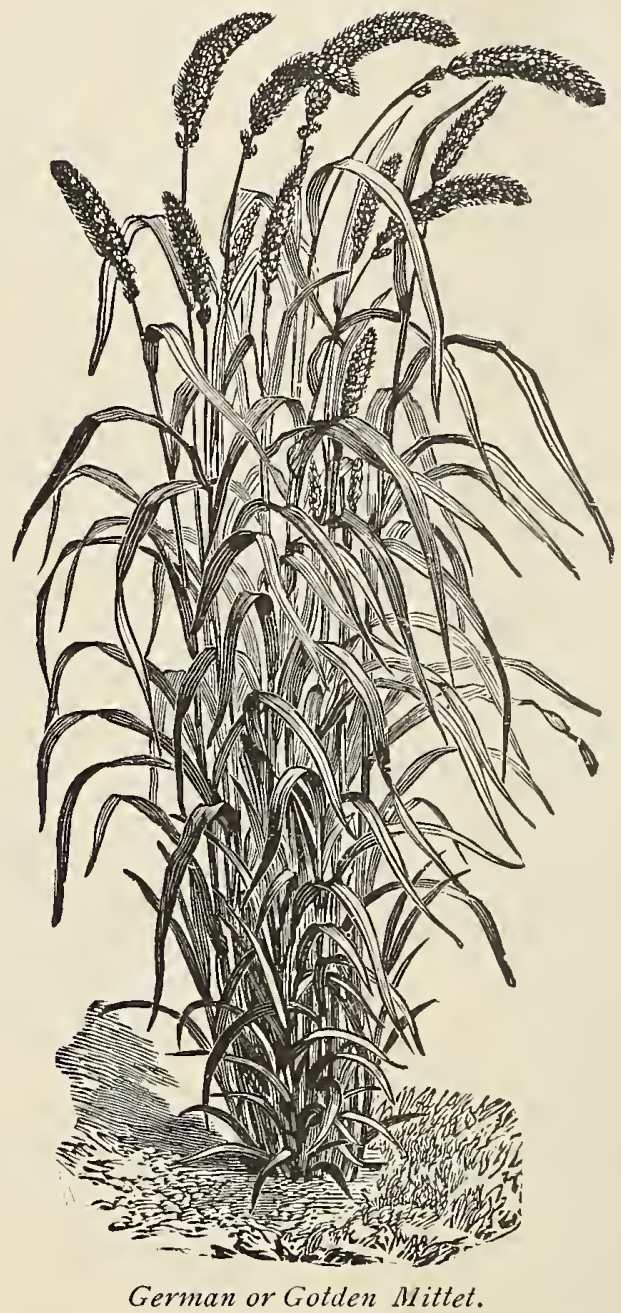

Golden or German. This is a valuable forage plant and yields very heavy crops; grows from two to four feet high, heads single and similar to Hungarian, though larger and with bright yellow oval seeds. Price per qt., Ioc.; per bu., $\$$ I.25; per 1001 bs., $\$ 2.50$. 


\section{GLOVER.}

Crimson Trefoil or Scarlet Italian Clover. ( $T$ rifolium Incarnatum.) This is a variety in common use in the South for feeding green. The yield in fodder is immense, and after cutting, it at once commences growing again, and continues until severe, cold, freezing weather. In warm climates, four or five cuttings are made during the season. It grows about one foot high, blossoms long, pointed, and of a very deep red or carmine color. Makes good hay. Price per 1b., I 2c.; per Ioo 1bs., \$10.0o.

Red Clover, Mammoth or Pea Vine. Grows five or six feet high, with large, coarse stalks, and is largely used for plowing under for manure. Prices on application.

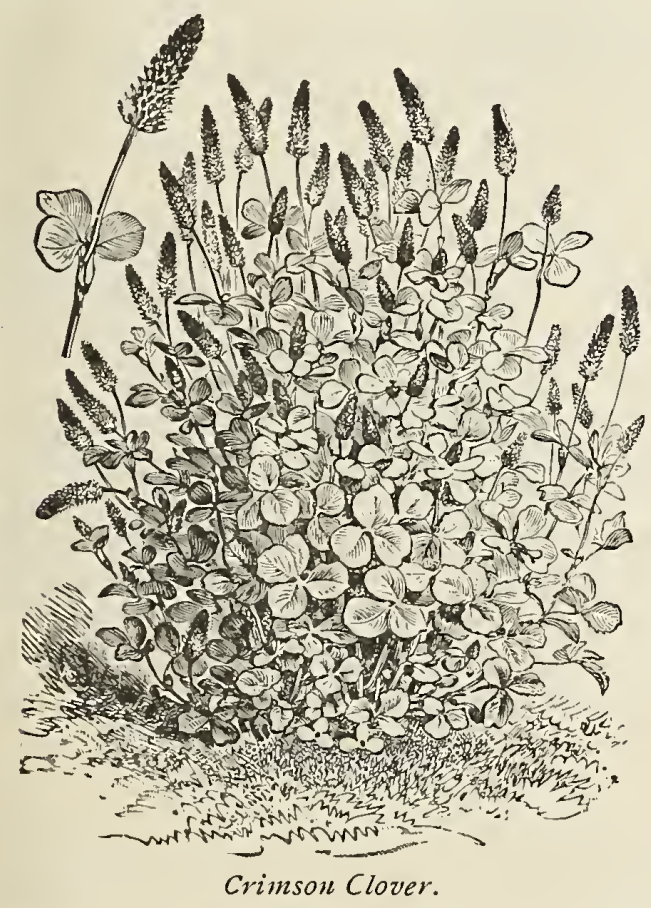

Aliske or Hybrid Clover. (Trifolium Hybridum) Even clover-sick lands will produce a good crop of this; perennial and very hardy. It is very valuable both for pasturing and soiling; very productive, sweet and fragrant. The fluwers are a distinct light pink, and much liked by bees. Sow in spring or fall, six pounds per acre. Price per 1b., 2oc.; 25 lbs. and over at isc.

Lucerne or Alfalfa. (Medicago Sativa.) Very productive, succeeds in any good soil, and lasts for a number of years. It thrives on dry, rich sandy soil, producing three to four cuttings annually, and even in seasolls of severe drought is always fresh and green, because the roots extend so deep into the soil. It grows two to three feet high, with purple blossoms. It yields an immense amount of green food for cattle, and should be cut when commencing to bloom, or it can be used as ordinary clover hay. Instead of exhausting the land, it increases fertility, but does not succeed on compact clay or on land with impermeable subsoil. Sow Io to I5 pounds per acre. Price per 1b., I5c; 25 lbs. and over at I3c.
White Du'ch. (Irifolium Repens.) Thrives best in damp locations, and while not a heavy producer, it is valuahle in permanent pastures. In connection

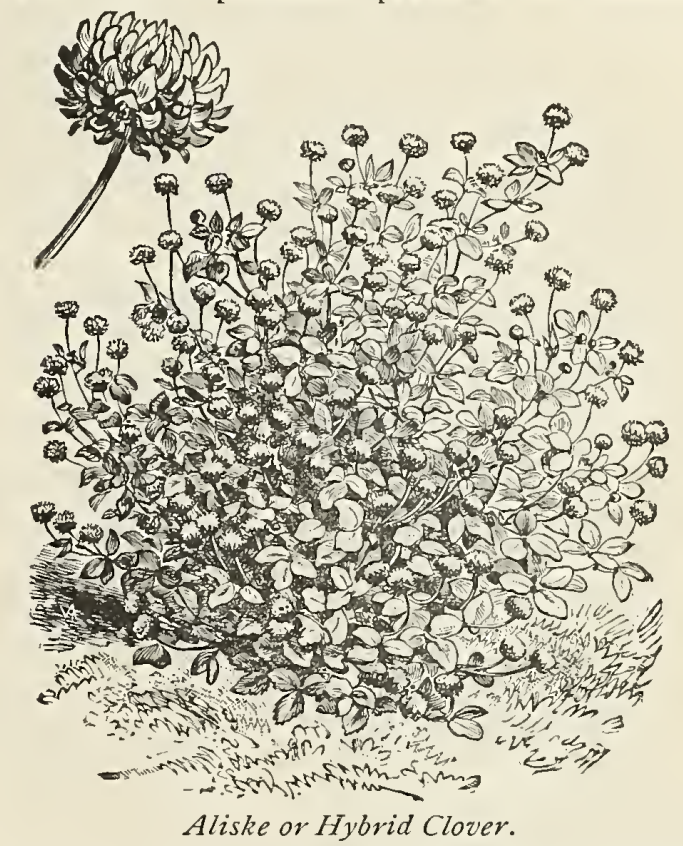

with Blue Grass it affords the most nutritious food for sheep and cattle, and also makes a fine mixture for lawns. Price per oz., 5c.; per $1 / 4$ lb., Ioc.; per 1b., 25c.; 25 lbs, and over, $20 \mathrm{c}$.

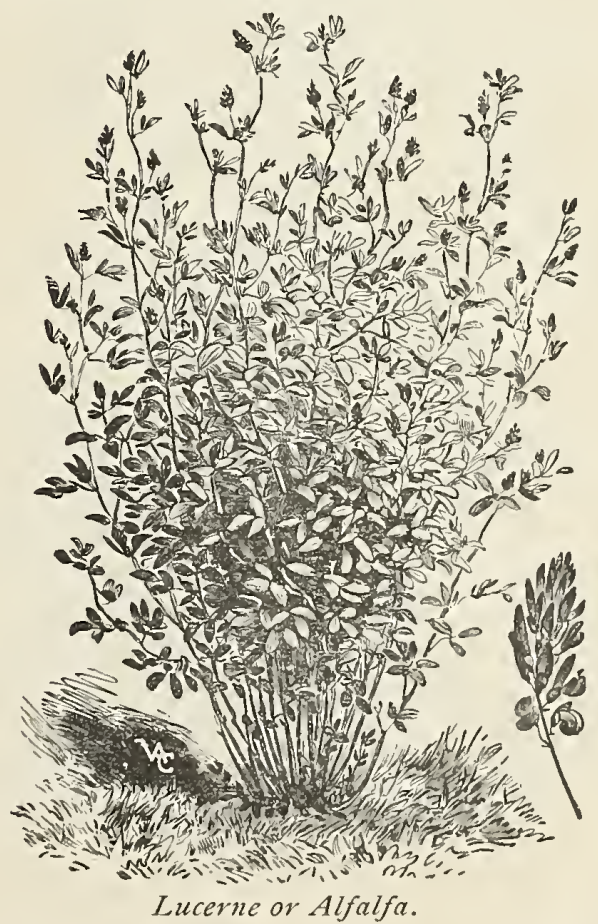

Red Clover, Medium. (7rifolium Pratense.) The common variety, used with other grasses for either pasture or meadow, Prices on application. 


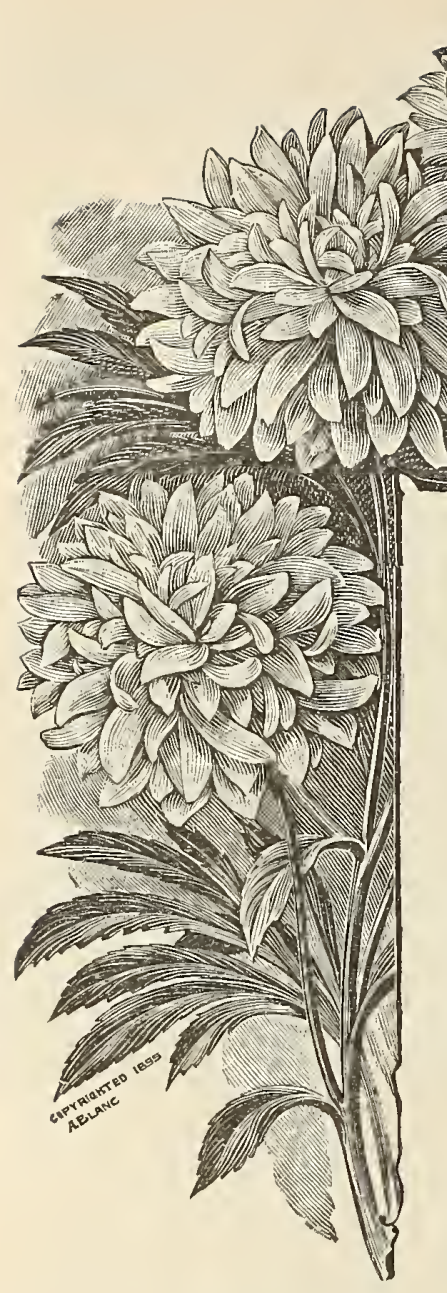

PLATT'S

SELECTED

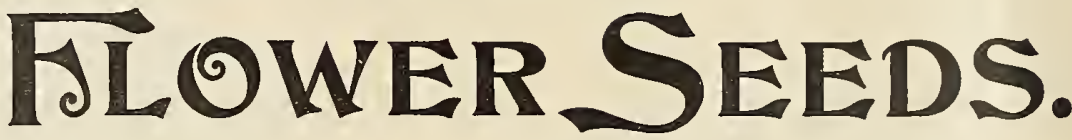

\section{ABRONIA.}

Extremely pretty creeping plant; verbena-like heads of sweet-scented flowers; very effective in beds, rock work or hanging baskets. Half-hardy annual. Umbellata. Rosy Lilac. White. Price per pkt., 5c. Arenaria. A beautiful yellow variety. Price per pkt., IOC.

\section{AGERATUM.}

A Mexican flower of blush-like appearance, suitable for bedding or pot culture. Blooms continually. Annual.

Mexicanum Lavender. Blue, two feet. Price per pkt., $5 \mathrm{c}$.

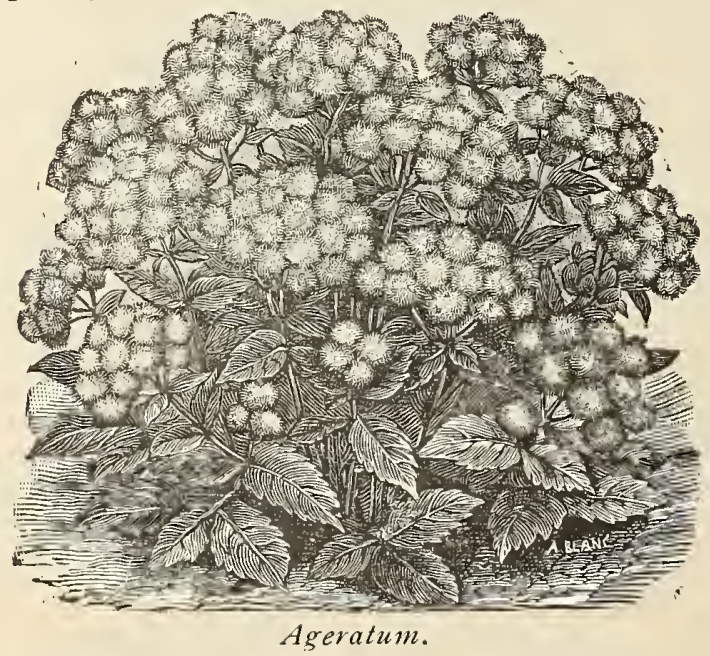

Tom Thumb. Blue, dwarf, six inches. Price per pkt., 5c.

Imperialis. Dwarf, white, eight inches. Price per pkt., $5 \mathrm{c}$.

\section{ADONIS.}

Showy border flowers, with pretty, five cut foliage; hárdy annual, lasting a long time in bloon.

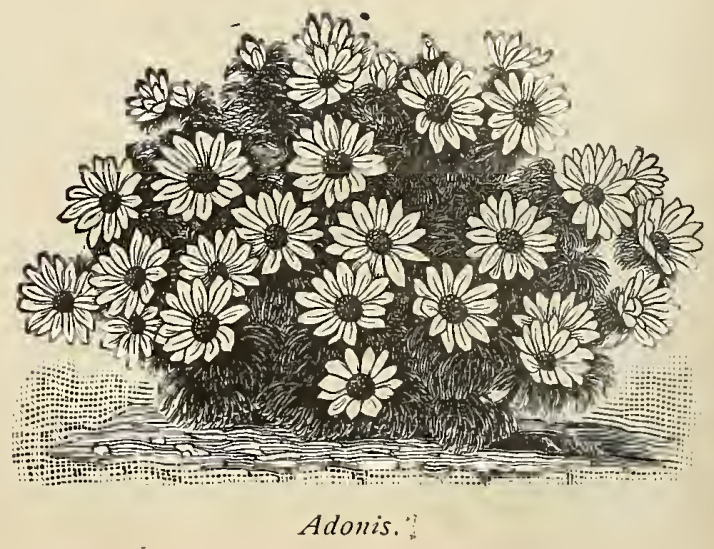

Estivalis. (Flos Adonis.) Scarlet. Price per pkt., 5 c. 


\section{ACROGLINIUM.}

Pretty summer-flowering annuals, bearing quantities of large double, everlasting flowers of white, rose, etc.

Double Mixed. Price per pkt., roc.

Rose. Price per pkt., 5c.

White. Price per pkt., 5c.

\section{AGROSTEMMA OR GROWN OF THE FIELD.}

An attractive, free-flowering hardy perennial, producing flowers on long,

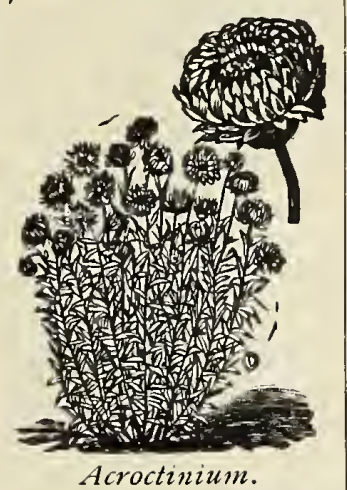
slender stems like a single pink; blossoms the first season. White and rose-colored flowers.

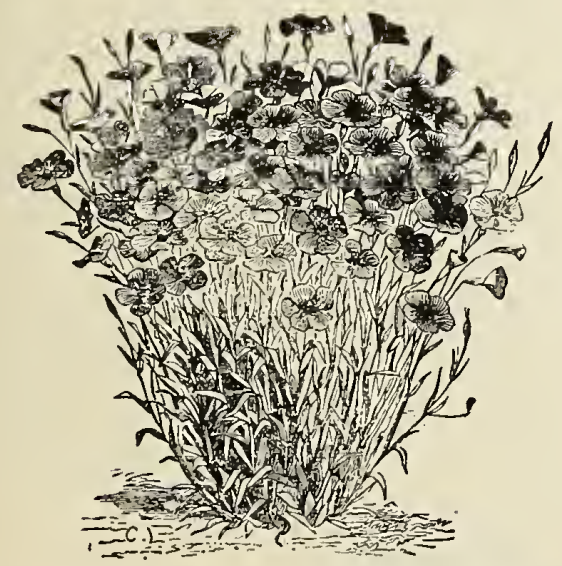

Agrostemma or Crown of the Fietd.

Cali Rosea. (Rose of Heaven.) Mixed. Price per pkt., 5c.

\section{ALYSSUM SWEET.}

A very pretty little plant for edging or ribbon lines, blooming all summer. Hardy annual.

Little Gem or Tom Thumb. (Compactum Erectum.) A fine plant for low beds and edgings. Price per pkt., 5c.

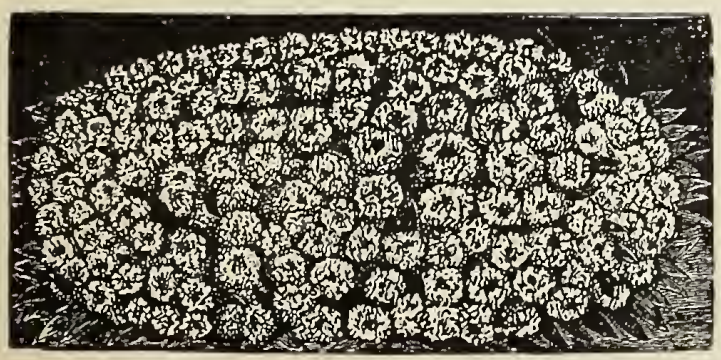

Alyssum, Little Gem or lom l lnumb.
White. In clusters, very sweet. Price per pkt., 5c.; per oz., 25c.

Saxatile Compacta. Golden yellow flowers. Hardy perenuial. Blooms the first season. Price per pkt., 5c.

\section{AMARANTHUS.}

Ornamental foliage plants of extremely brilliant and showy colors. Half-hardy annual.

Tricolor. (Joseph's Coat.) Leaves yellow, red and green. Price per pkt., 5c.

Caudatus. (Love Lies Bleeding.) Flowers in bunches of long, drooping, chenile-like tassels. Price per pkt., $5 \mathrm{c}$.

Salicifolius. (Fountain Plant.) Gracefully drooping, willowy-shaped leaves. In the latter stages of growtli the leaves are brilliantly banded and tipped with orange, carmine and bronze. Price per pkt., $5 \mathrm{c}$.

\section{ANTIRRHINUM.}

\section{Snapdragon.}

One of the most useful summer-flowering perennials, producing long spikes and beautiful brightcolored flowers, the first season.

Tom Thumb. Mixed. Price per pkt., $5 \mathrm{c}$.

Tall Mixed Colors. Price per pkt., $5 \mathrm{c}$.

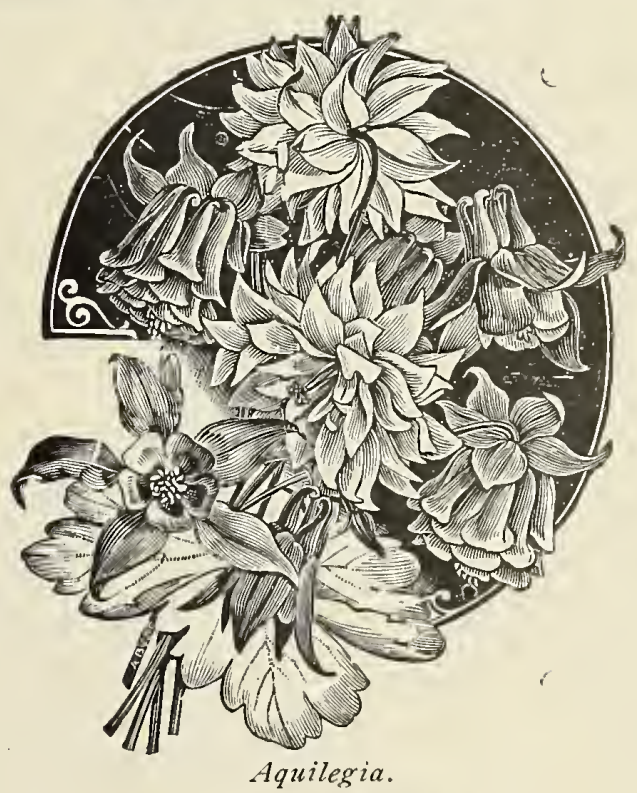

\section{AQUILEGIA.}

\section{Cotumbine.}

A very showy class, with curiously shaped blossoms in great variety of colors; ranks among the finest early flowering plants. Hardy perenuials.

Double Varieties. In finest mixture. Price per pkt., 5c.

Single Varieties. All colors mixed. Price per pkt., 5c.

Chrysantha. Golden spurred flowers. Price per pkt., Ioc.

Chrysantha Alba. Pure white, witl long spurs Price per pkt, $15 \mathrm{c}$. 


\section{ASPERULA.}

A profuse blooming, hardy annual, attaining an average growth of one foot. The flowers, which are beautiful light blue, are very sweet scented, and last long while in perfection.

Odorata. (Sweet Woodruff.) The dried flowers and leaves have a delicious perfume and impart an agreeable perfume to clothes, etc., when kept among them. Price per pkt., 5c.

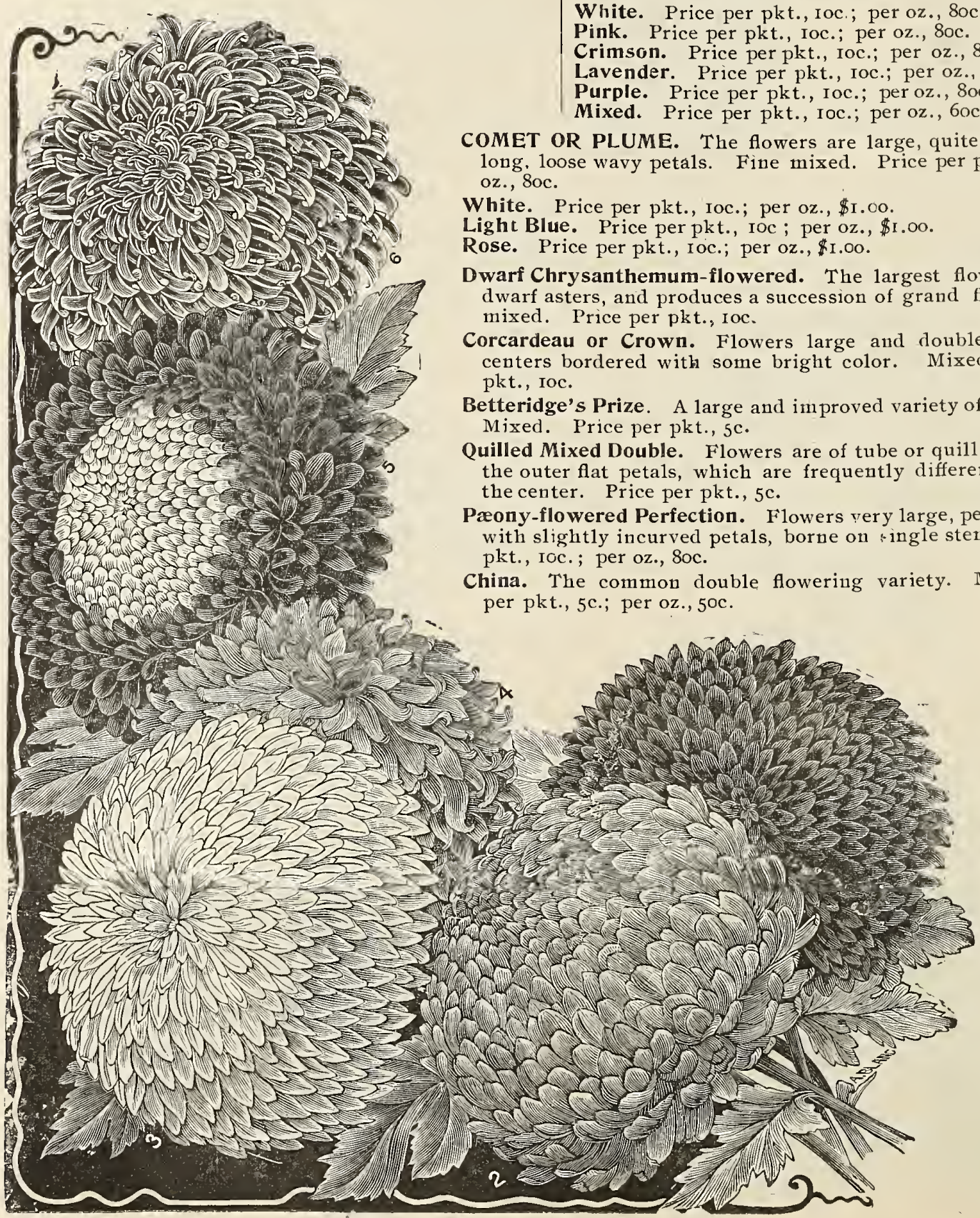

VICTORIA. A magnificent strain of asters, flowers very large, double, globular and of striking and beautiful colors.

Snow White. Price per pkt., Ioc.; per oz., \$r.oo.

Rose. Price per pkt., Ioc.; per oz., \$1,oo.

Dark Blue. Price per pkt., Ioc.; per oz., \$I.oo.

Fine Mixed. Price per pkt., Ioc.; per oz., 8oc.

SEMPLES BRANCHING. This is a fine type of the California branching asters, growing eighteen inches to two feet high. Flowers very large and a little later than all other varieties.

White. Price per pkt., Ioc.; per oz., 8oc.

Pink. Price per pkt., Ioc.; per oz., 8oc.

Crimson. Price per pkt., roc.; per oz., 8oc.

Purple. Price per pkt., Ioc.; per oz., $80 \mathrm{c}$

double, with long, loose wavy petals. Fine mixed. Price per pkt., Ioc.; per oz., 8oc.

Light Blue. Price per pkt., IOc ; per oz., \$I.oo.

Rose. Price per pkt., Ioc.; per oz., \$1.00.

warf Chrysanthemum-flowered. The largest flowering of the dwarf asters, and produces a succession of grand flowers. Fine

rordeau or Crown. Flowers large and double, with white centers bordered with some bright color. Mixed. Price per

tteridge's Prize. A large and improved variety of quilled sorts.

uilled Mixed Double. Flowers are of tube or quill shape, except the outer flat petals, which are frequently different color than hina. The common double flowering variety. Mixed. Price Price 


\section{BALLOON VINE.}

\section{Cardiospermum.}

A genus of rapid-growing, handsome climbers, remarkable for an inflated membraneous capsule, from which it is somet imes called "Balloon Vine."

Ha $\mathbf{l}$ ic ac a b u m. White.

Price per pkt., 5c.

\section{BALSAM.}

They are among the showiest and most popular Love in a Puff.

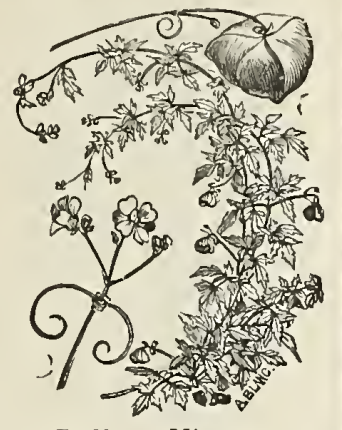

Balloon Vine. of our summer garden annuals, forming bushy plants, covered with large double flowers, of brilliant colors.

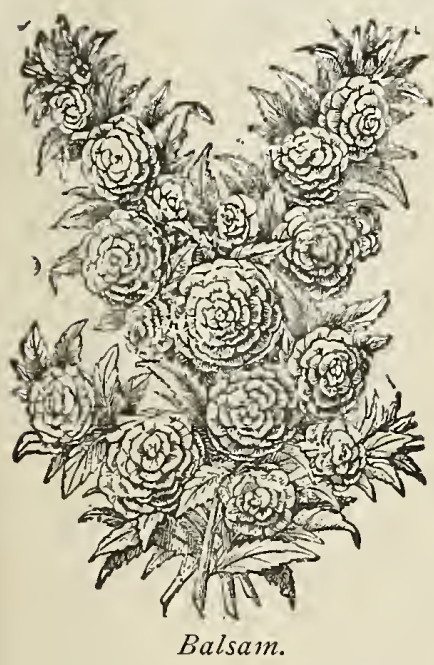

Double Fine Mixed. Per per pkt., 5c.

Double Camelia Flowered. Finest mixed. Price per pkt., 5c.

Double Camelia White. Price per pkt., 5c

Double Scarlet. Price per pkt., 5c.

Double Flesh Color. Price per pkt., 5c.

\section{Balsam Apple.}

(See Mormordica.)

\section{BRANGHYGOME.}

Swan River Daisy.

An annual, growing six to eight inches high, and covered all summer with a profusion of single blue and white daisy-like flowers. Price per pkt., 5c.

\section{BARTONIA:}

Half-hardy anuual. The flowers are a very bright metallic yellow, and exceedingly brilliaut in the suushine. It likes considerable nloisture and suffers in a drought. Plants grow seventeen inches to two feet high, with thistle-like, downy leaves.

Aurea, Golden yellow. Price per pkt., 5c.
BELLIS PERENNIS.

Double Daisy.

Prefers a cool, sheltered situatiou, and needs some protectiou in the winter. Flowers are quilled or flat petaled, white, red or variegated. Half-hardy perennial.

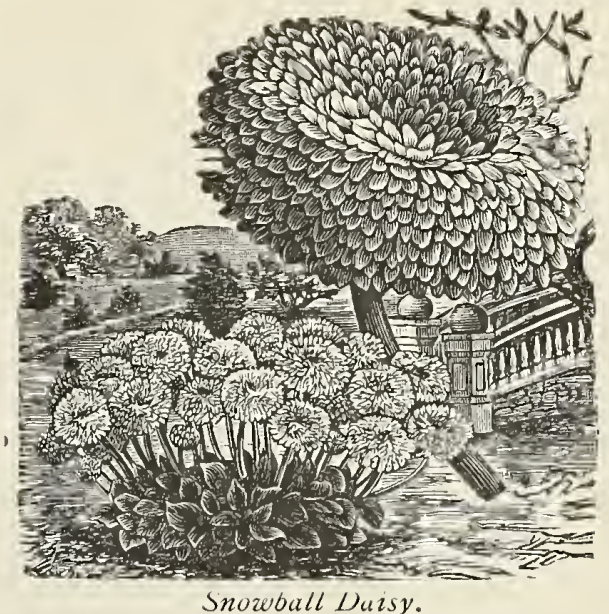

Snowball. Pure white, large and very double. Price per pkt., I oc.

Longfellow. Fine, large, double dark rose flowers. Price per pkt., Ioc.

Double Quilled. Mixed. Price per pkt., roc.

Double Mixed. Price per pkt., Ioc.

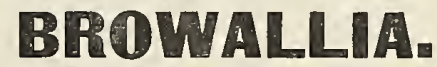

Profuse blooming plants, continuing throughout the summer, studded with blue and white flowers, growing freely in any rich soil. Half hardy annual.

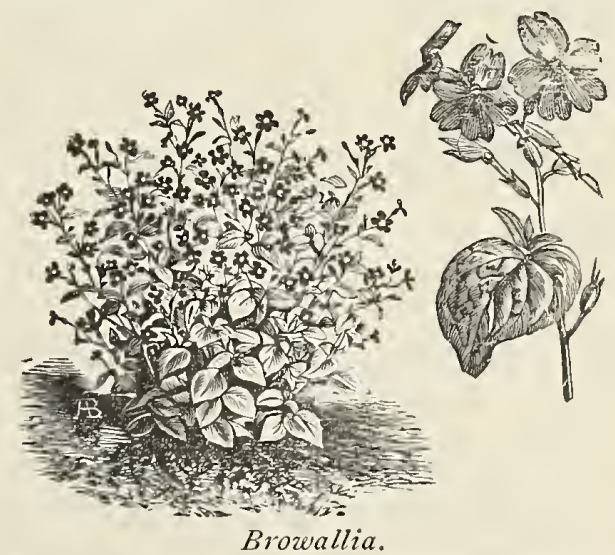

Elata Corulea. Sky blue with white eyes. Price per pkt. $5 \mathrm{c}$.

Elata Alba. Pure white. Price per pkt., 5c.

\section{GAGALIA.}

7assel Flower.

A pretty half-hardy annual, with tassel-shaped flowers, scarlet and golden yellow. Blooms from July to September.

Mixed Colors. Price per pkt., 5c. 


\section{GALANDRINIA.}

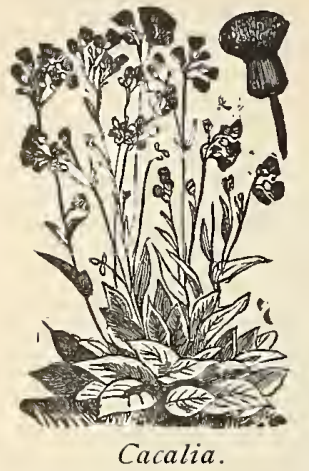

Large Flowered. pkt., $25 \mathrm{c}$.

Rugosa Shrubby or Bedding Varieties. Mixed. Price per pkt., $25 \mathrm{C}$.

\section{GALENDULA. Marigold.}

$\mathrm{Sh}$ ow $\mathrm{y}$, free-flowering hardy annuals, growing in any good garden soil, producing a fine effect in beds or mixed borders, and continuing iu bloom until killed by frosts.

Mete or. Large, double, light yellow flowers, striped with bright orange. Price per pkt., 5c.; per oz., $25 \mathrm{c}$.

Pongei fl. pl. Large, pure white. Semi-double. Price per pkt., $5 \mathrm{c}$.

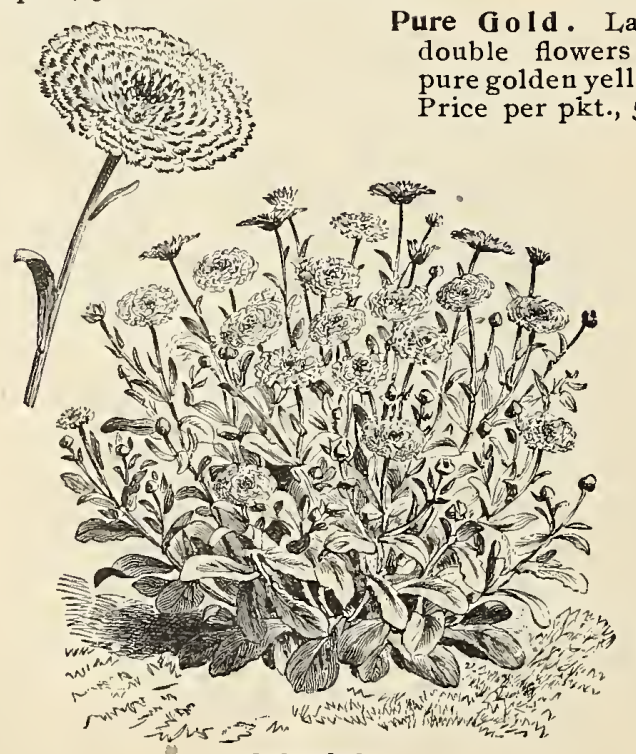

Calendula.

Prince of Orange. Grows from ten to twenty inches iu height, with a profusion of flowers during the entire summer. Price per pkt., 5c.; per oz., 25c.

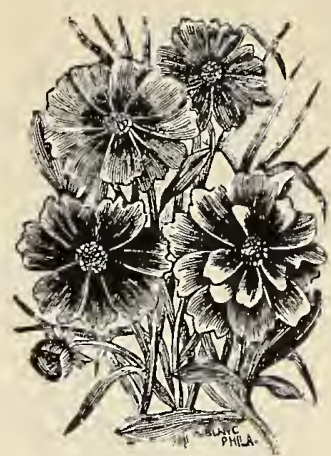

Calliopsis or Coreopsis.

\section{Calliopsis or Coreopsis.}

Few, if any, annuals are more useful than these; the colors are rich and striking ; flowers numerous and beautiful. Hardy annual.

Fine Mixed. Price per pkt., $5 \mathrm{c}$.

Coronata. Large single ye1low flowers. Price per pkt., $5 \mathrm{c}$.

Golden Wave. (Drummon. dii.) Plants very bushy and compact, and covered with large golden blossoms having dark centers. Price per pkt., $5 \mathrm{c}$.

Double. Rich golden yellow, maroon spotted. Price per pkt., $5 \mathrm{c}$.

\section{Campanula.}

Hardy, herbaceous perennials, bearing attractive bell flowers, thriving hest in light rich soil ; some of the varieties flower in first season if planted early. Carpatica and Speculum are fine for beds, edgings and ribbon gardening.

Campanula Pyramidalis. Blue and white mixed; hardy perennial; three feet. Price per pkt., $5 \mathrm{c}$.

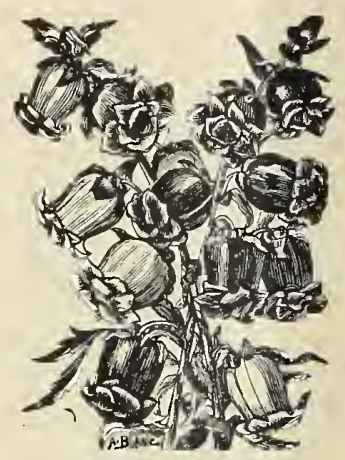

Campanula.
Carpatica Mixed. Free flowering, blue and white mixed, continuing in bloom tha whole season; hardy perennials; six inches. Price per pkt., $5 \mathrm{c}$.

\section{CANTERBURY BELLS.}

Media, Single Mixed. Beautiful, large, bell-shaped flowers; hardy biennials; two and one-half feet. Price per pkt., $5 \mathrm{c}$.

Media, Double Mixed. Two and one-half feet. Price per pkt., $5 \mathrm{c}$.

Media Calycanthema. (Cup and Saucer.) This is the finest variety of Campanula, producing plants with white and blue flowers, resembling cup and saucer; mixed. Price per pkt., Ioc.

\section{Canary Bird Flower.}

7 ropocolum Canariensis.

An exceedingly ornamental creeper, with bright, yellow fringed flowers, resembling a canary bi $r d$ with wings partly spread, and neat, finely divided foliage; a general favorite.

Yellow. Price per pkt., $5 \mathrm{c}$.

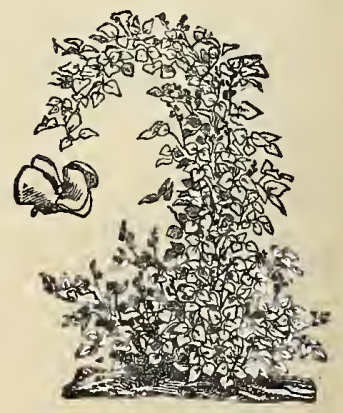

Canary Bird Flower. 


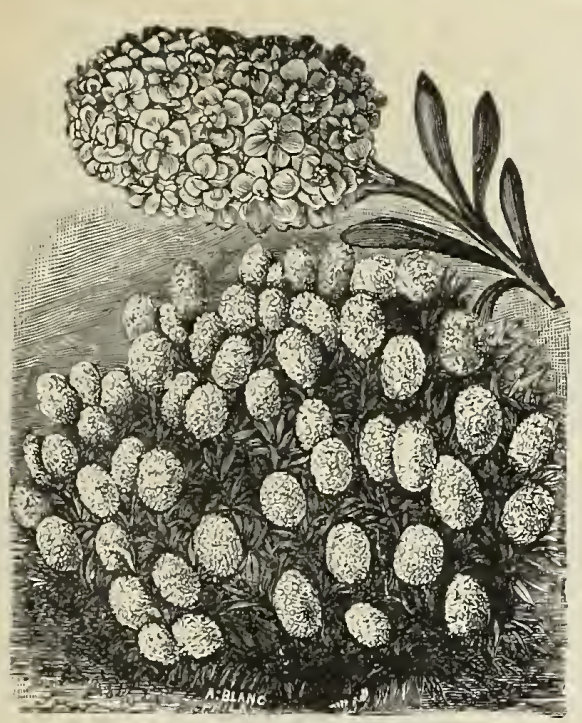

Empress or Snow Queen Candytuft.

\section{GANDYTUFT.}

Seed sown in April flower from July to September, and some of the sorts till frost comes. All the varieties are hardy and easy to cultivate. Single plants look well and bloom profusely. Hardy annuals, one foot high.

Empress or Snow Queen. Pure white flowers, borne on a candelabra-shaped plant. Per pkt., roc:

Carmine. Price per pkt., $5 \mathrm{c}$.

Crimson. Price per pkt., $5 \mathrm{c}$.

Lilac. Price per pkt., $5 \mathrm{c}$.

White Fragrant. Price per pkt., 5c.

White Rocket. Price per pkt., 5c.

Mixed Colors. Price per oz., 2oc.; per pkt., 5c.

Perennial. (Iberis Sempervirens.) Hardy, low growing, compact plant; blooms early in spring, in masses of pure whits. Fine for border edges or cemetery planting. Price per pkt., roc.

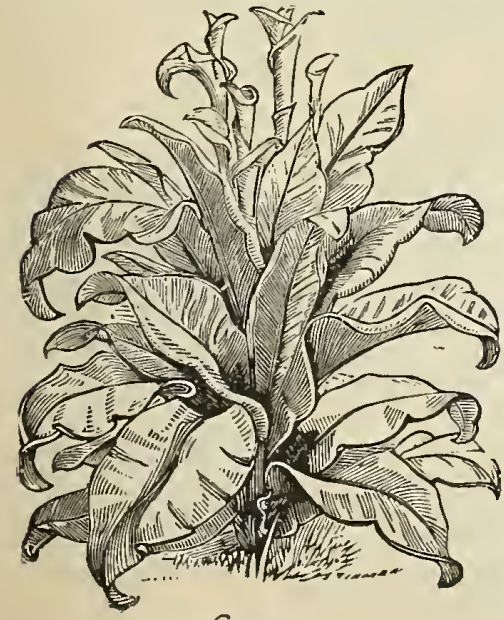

\section{GANNA.}

(Indian Shot.)

The seed shells are very hard, and to facilitate germination it is a good plan to soak them in warm water ten or twelve hours before planting.

D w a rf Large Flowered French. Their great merit lies in the large size and brilliant hues of the $\mathrm{flow}$. ers, ranging through all shades Canna.

ange to the richest crimson, scarlet and vermilion; some are also beautifully spotted. Mixed. Price per pkt., roc.

\section{GASTOR OIL BEANS.}

(See Ricinus.)

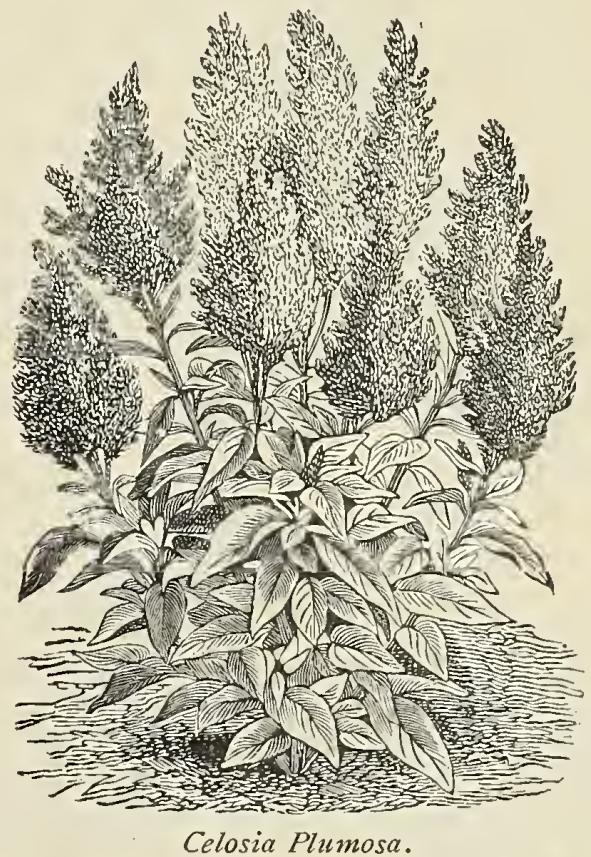

CELOSIA Or COXCOMB.

A very desirable and showy plant, producing large combs of crimson or yellow flowers. The "Cristata" sorts are the well-known Coxcombs.

\section{Cristata, the True Cockscomb.}

Mixed Including many colors. Price per pkt., $5 \mathrm{c}$. Dwarf Crimson. One foot, " " " $5 \mathrm{c}$ Golden Beauty. Golden yellow, " " " $5 \mathrm{c}$. Japonica. Pyramidal plant, composed of crimson branches, each bearing a comb of the same color, and finely ruffled. Price per pkt., $5 \mathrm{c}$.

Glasgow Prize. Very dwarf, immense crimson combs. One foot. Price per pkt., roc.

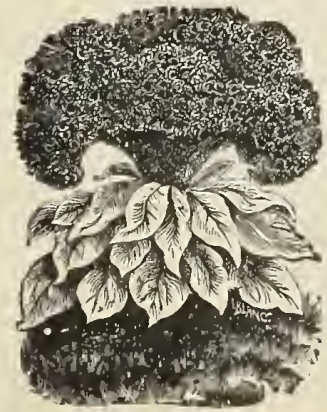

Cristata.

\section{Plumosa, or Feathered} Goxcomb.

Plants surmounted with long feathery plumes; exceedingly handsome.

Plum osa, Golden Yellow. Three feet. Price per pkt., Ioc.

Scarlet. Three feet. Price per pkt., roc. 


\section{GARNATION.}

Carnations and Picotee Pinks are general favorites for their delicious fragrance and richness of colors. The seed we offer will produce many splendid novelties in double or semi-double flowers; protect during the winter; half-hardy perenuials; $\mathrm{I} / 2$ feet.

Carnation, Finest German. Mixed colors; saved from fine double-named flowers. Price per pkt., ${ }_{5} \mathrm{C}$.

Fine Double Mixed. The hardiest and best varieties for garden culture. Price per pkt., roc.

Marguerite. Flowers four months after sowing the seed, its profusiou of bloom, variety of beautiful colors and delicious perfume, insure its popularity in all gardens where cut flowers are in demand. Price per pkt., roc.

\section{GENTAURA.}

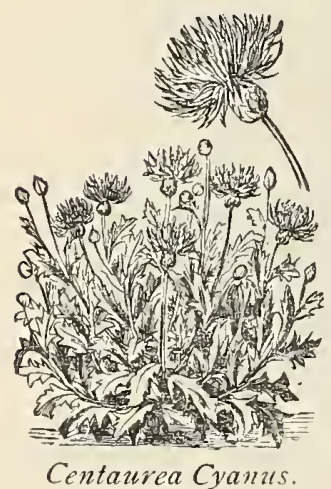

Centaurea Cyanus.

Known as "Blue Bottle,"

"Corn Flower," "Ragged

Sailor, " etc., fine for cut

flowers; two to three feet.

Blue. A very old, favorite annual, flowering freely in almost any situation. Price per pkt., 5c.

Centaurea Marguerite. I,trge, pure white blooms. Price per pkt., Ioc.

Mixed. Price per pkt., 5c.

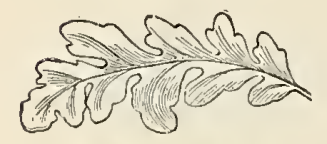

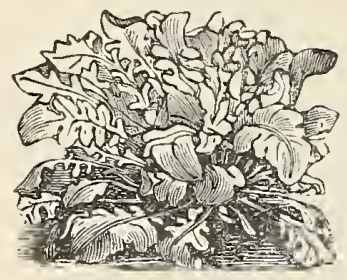

Centaurea Candidissima.

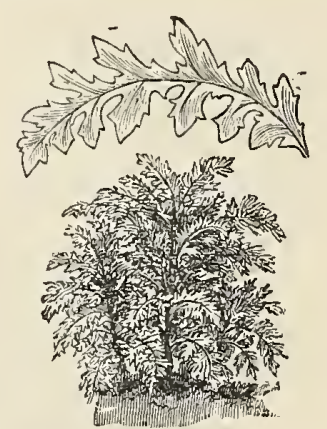

Centaurea Gymnocarpa.

\section{White-Leaved or Dusty Miller Varieำiอs.}

Valuable plants for ribbon bedding. The silvery whiteness of the leaves being very effective with other colored leaved plants.

Gymnocarpa. Graceful, fine-cut silvery white foliage.

One and one-half feét. Price per pkt., Ioc.

Candidissima. Silvery, broad-cut leaves, Price per plet, $35 \mathrm{e}_{\text {, }}$

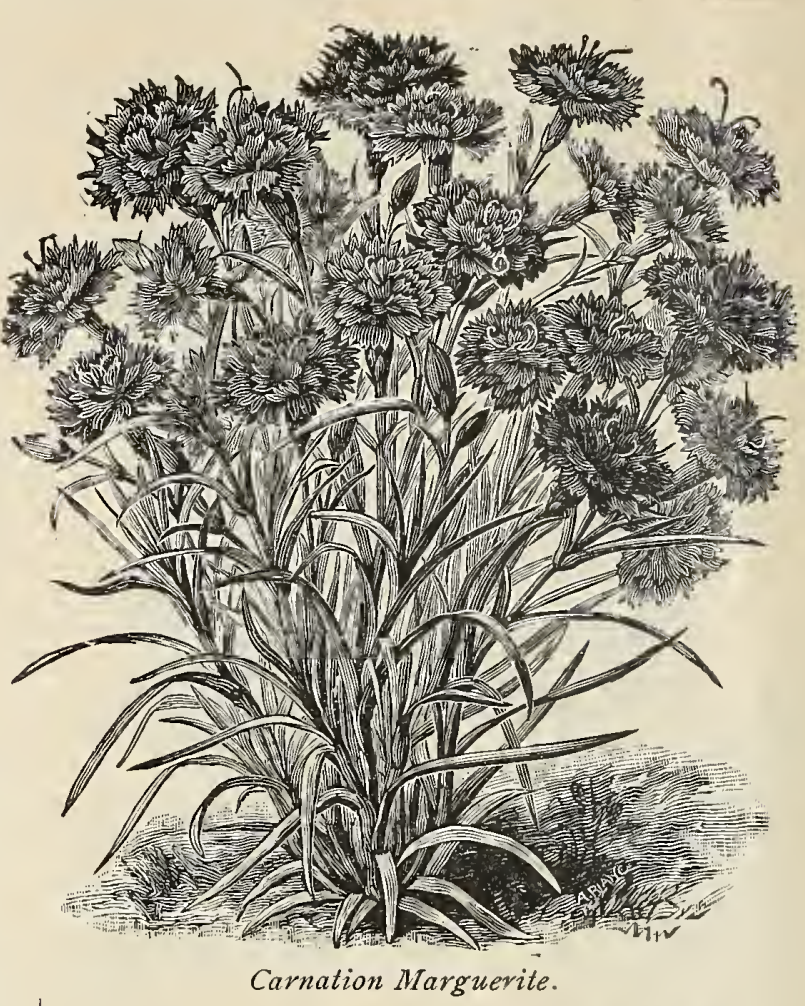

\section{GHRYSANTHEMUM.}

The annual varieties are exceedingly pretty. They are bright, free bloomers, rapid in growth, and merit a prominent place in every annual garden. They are also good for ordinary bouquetcutting. All the annual Chrysanthemums make beautiful pot plants, if sown in cold frames and pricked off singly into six-inch pots. They are perfectly hardy.

Segetum Grandiflorum. The golden Marguerite; large, bright yellow flowers. Price per pkt., Ioc.

Burridgeanum, or Lord Beaconsfield. Crimsou, maroon edged, and striped gold, brown eye, ringed yellow. Price per pkt., Ioc.

W. E. Gladstone. A pure, brilliant, ricli crimson. Price per pkt., Ioc.

Carinatum Eclipse. Pure golden, witl a bright, purplish-scar let ring and dark brown disc; very striking. Price per pkt., Ioc.

Mixed Single Annual Vari= eties. Price per pkt., $5 \mathrm{c}$.

Coronarium, Double Yellow. Handsome border plants, two feet. Price per pkt., 5c.

Double White. Very showy, two feet. Price per pkt., 5 c.

Mixed Double Annual Va= rieties, Price per plat.s $5 c_{4}$

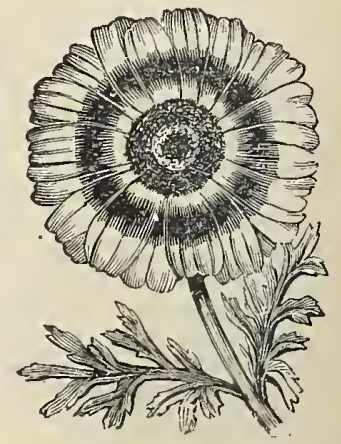

Single Chrysanthemum. 


\section{GHRYSANTHEMUIII Continued.}

The following varieties are for pot culture in the house and for florists' bouquets.

Japonicum, fl. pl. (New Japanese variety.) Flowers of peculiar form aud much beauty, combining numerous shades of color. Very interesting. Half-hardy perennial. Price per pkt., 25c. Inodorum Plenissimum. Dwarf-growing, double white variety, very fine flowering and beautiful for pot culture. Price per pkt., roc. Frutescens Grandiflorum. ("The MTarguerite" or "Paris Daisy.") Inmense quantities are grown by French florists, and find a ready sale. It produces freely its white, star-like flowers under the most unfavorable conditions. Price per pkt. roc.

\section{GLEOME.}

(The Giant Spider Plant.)

Seed sown in the open ground in May will commence blossoming July Ist, and continue until frost, attaining a height of five or six feet. The flowers are deep purple pink when they first open, but fade to a light pink. The stamens are several inches long, which gives it the uame of Spider flower.

Pungens. Price per pkt., 5c.

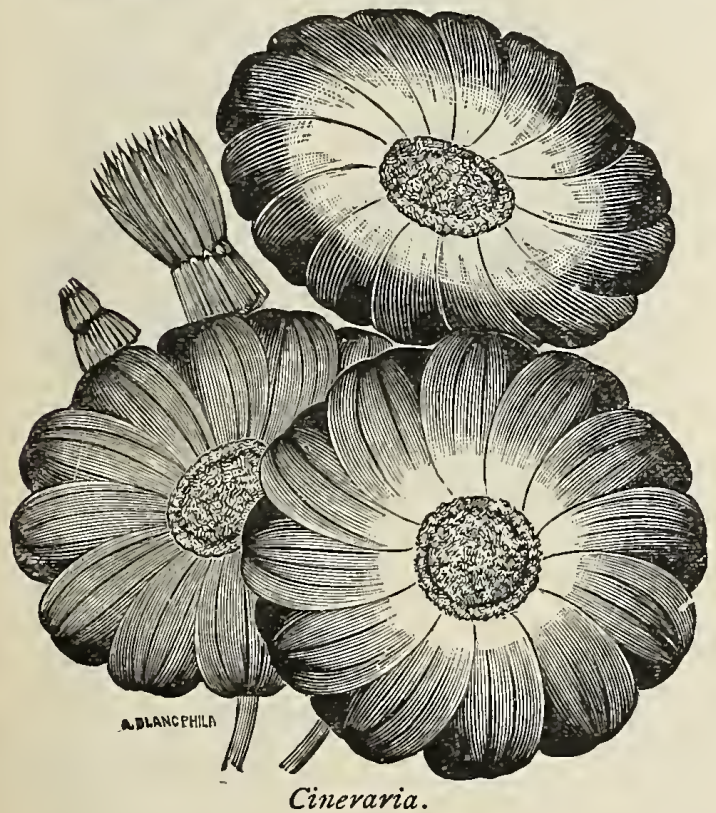

A magnificent greenhouse plant having a range aud brightness of color seldom equaled. Sow seeds from May to July.

Hybrida. Large Flowering. B ri 11 ia $11 \mathrm{t}$ blossoms, beautifully marked colors. Price per pkt., $25 \mathrm{c}$.

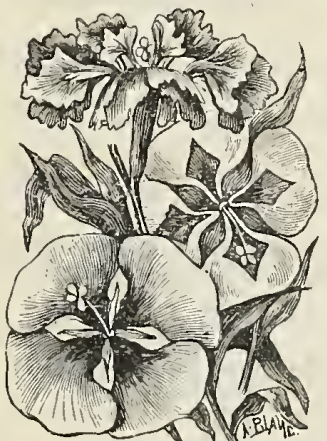

Clarkia.

Fine Mixed. Choice strain of showy and bright colors. Price per pkt., I5c.

Maritima. (Dusty Miller.) Silvery foliage, fine for bedding, edging and ribbon planting. Price per pkt., $5 \mathrm{c}$.

\section{CLARKIA.}

An old favorite a $\mathrm{n} \mathrm{n}$ u a 1 , growing and producing freely its flowers under almost any circumstances. Finest Mixed. Price per $\mathrm{pkt}$., $5 \mathrm{c}$.

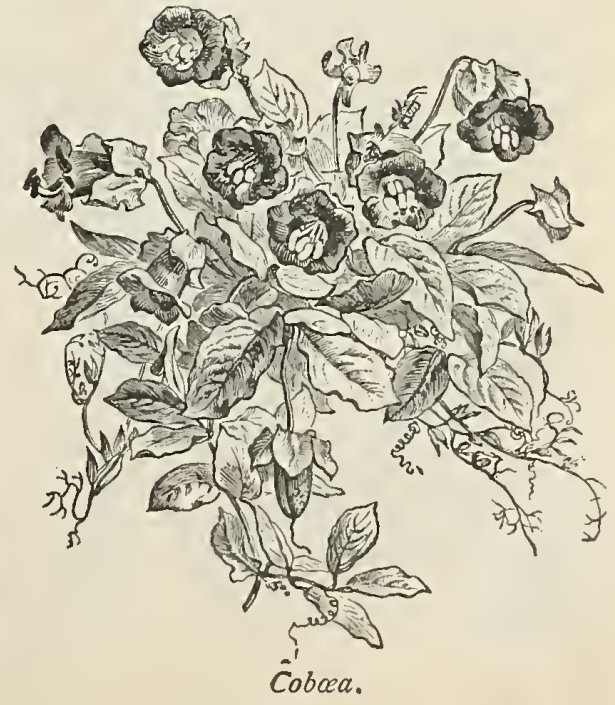

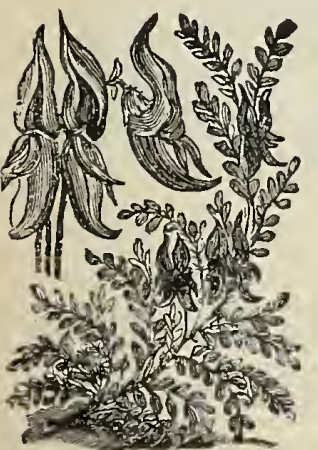

Clianthus Dampieri.

\section{clianthus.}

(Australian Glory Pea.)

Magnificent plants which should be grown in light, rich soil. A shrubby, tender greenhouse perennial.

Dampieri. Flowers in clusters, pea-shaped; four to six inches in length ; of brilliant scarlet. Price per pkt., Ioc.

\section{COBOEA.}

A beautiful rapid-growing climbing plant, with large, handsone, bell-shaped flowers. Sow early and plant out about June. In sowing, plant the seeds edgewise, and cover lightly.

Scandens. Price per pkt., Ioc. 


\section{COCKSGOMB. (See Celosia.)}

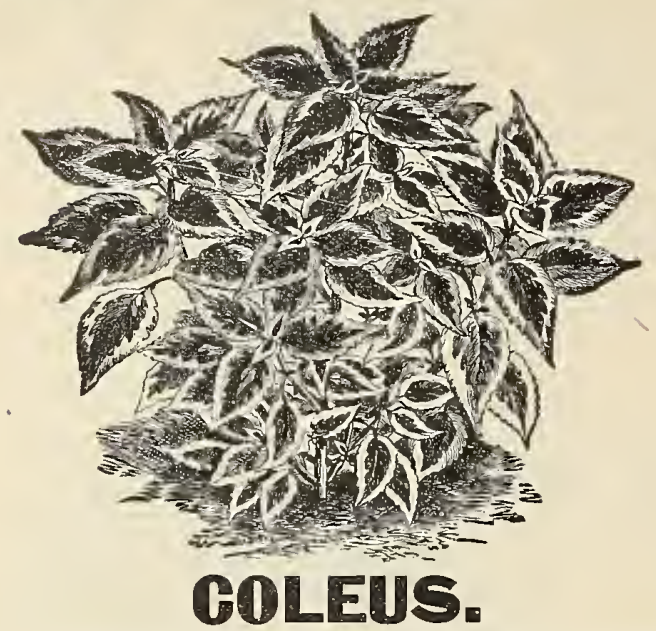

A distinctive foliage plant with large, brilliantly colored leaves ranging through shades of scarlet, yellow, green and variegated markings. Sow early in soring,

Fine Mixed. Price per pkt., roc.

Choice Large Leaved Varieties. Price per pkt., 25c.

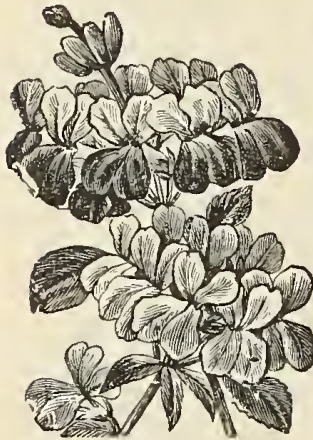

Collinsia.

\section{COLLINSIA.}

Very pretty free-flowering plants, blooming in whorls and several whorls around each flower stem ; hardy annual; I $1 / 2$ feet.

Collinsia Mixed. Price per pkt., 5c.

\section{COLUMBINE.} (See Aquilegia.)

\section{Convolvulus.}

(Morning Glory.)
Major. Free-flowering climber, succeeds in almost any situation. Height, fifteen feet. Fine mixed. Price per pkt., 5c.; per oz., I5c.

The Japanese Morning Glory. The flowers are almost unlimited in variety of colors, from purest white through all the different shades of pink, rose,

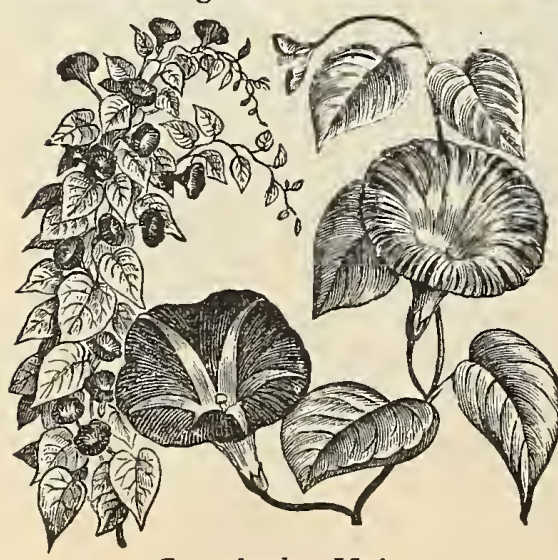

Convolvulus Major. red, carmine, crimson, blue, purple and maroon. Sow early in a warm, sunny place, or, to gain time, start the seeds in the house.

C ho i c e Mixed. Price per pkt., 5c.; oz.. 2oc.

Tricolor $\mathrm{Mi}$ nor. "Bush Morning Glories" grow only about one foot high; the flowers are freely borne, and, if pleasant, remain all day. The plant spreads with much regularity, and a bed of them is a beautiful object all summer. Price per pkt., $5 \mathrm{c}$.

\section{cosmos.}

An autumn flowering plant, with feathery foliage. The flowers are borne profusely in loose clusters. Seed should be sown early in the spring and the plants transplanted in the open border when danger from frost is past. It begins bloom-

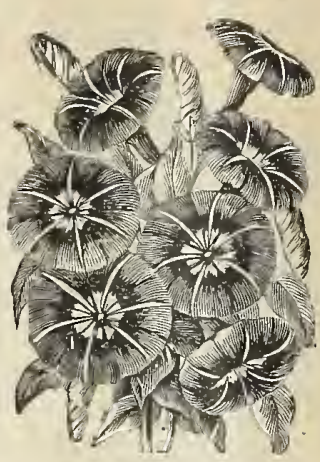

Convolvulus Minor. ing in August and continues until cut down by frost. For planting in shrubbery it will be found very valuable.

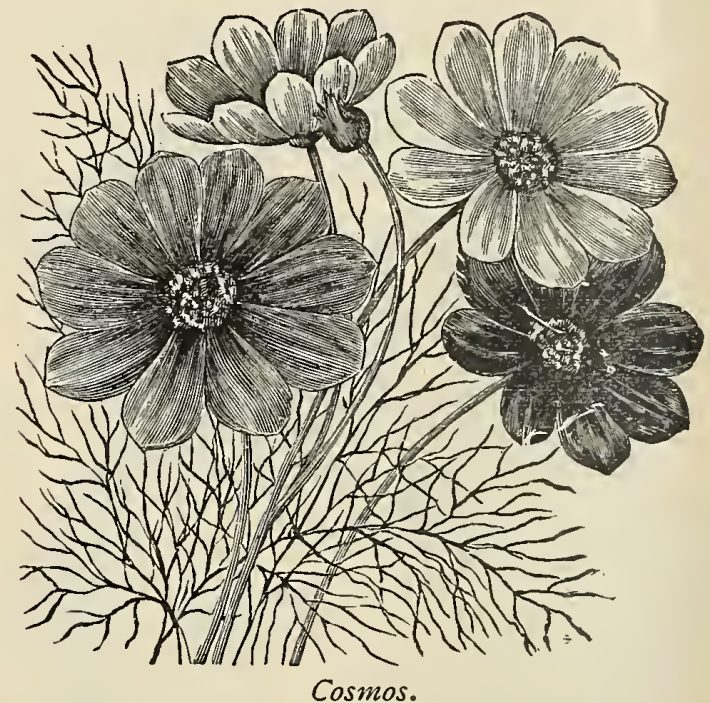

Hybridus Mixed. Price per pkt., 5c.

Hybridus, White Pearl. Price per pkt., $5 \mathrm{c}$.

Dwarf Yellow Cosmos. This forms a plant about 2 feet high; the flowers, about $I^{I} / 2$ inches across, are star-shaped and of a rich golden yellow. Price per pkt., 5c.

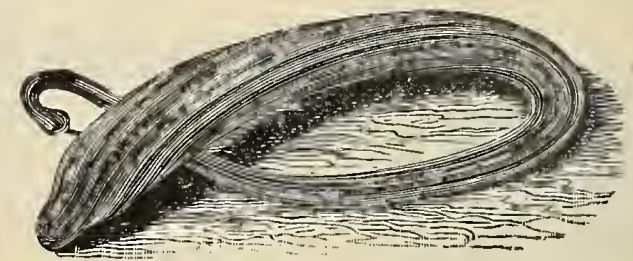

Snake Cucumber.

\section{CUCUMIS OR SNAKE CUCUMBER.}

Flexuosus. It is a rapid growing vine, quite ornamental, and often attaining a length of six feet. The fruits are curious, and, if allowed to fully ripen, can be kept for some time. Annual. Price per pkt., Inc. 


\section{GYCLAMEN.}

A genus of the most beautiful and elegant winter and spring blooming plants for pot culture in parlor or conservatory, universally admired. If sown early in spring under glass, and well grown, will make flowering bulbs in one year.

Persicum. Mixed, selected from finest varieties. Price per pkt., IOc.

Giganteum. Flowers of an extraordinary size, broad petals and stout flower stalks. Price per pkt., 25c.

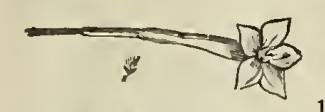

\section{GYPRESS VINE.}

A clinging plant with very delicate, fernlike foliage, and masses of beautiful, star-

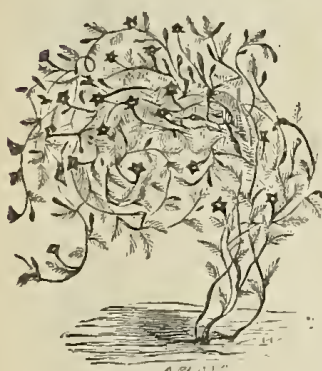

Cypress Vine. shaped flowers borne in clusters. Halfhardy annual.

Scarlet. Per pkt., 5c.; per oz., 3oc.

White. "5c.; "

Mixed. " 5 c.; "

One of our best autumnal flowering plants ; blooms until killed by frost; tuberous rooted, half-hardy perennials; blooming the first year from seed, if sown early; protect the roots during winter in a dry cellar in sand; two to eight feet.

Large Flowering. Saved from the finest double flowers. Price per pkt., Ioc.

Small Flowering. (Bouquet or Lilliputian.) Saved from choice double flowers; mixed colors. Price per pkt., Ioc.

Single Mixed. Large showy flowers, Price per pkt., Ioc.

\section{DAISY: Bellis Perennis.}

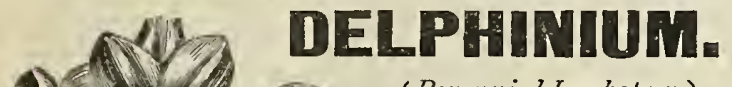

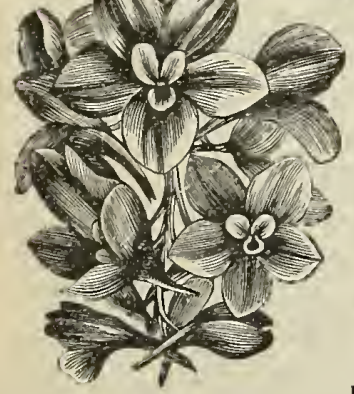

Delphinium.
(Perennial Larkspur.)

The tribe of Delphinium, to which the well-known Larkspur belongs, is one of the handsomest and most useful of all perennials, producing magnificent spikes of bloom in great profusion throughout the summer; if sown early they will flower the first season. Half-hardy perennial.

Formosum. Beautiful single variety; blue with white center. Price per pkt., 5c. Grandiflorum fl. pl. Finest double. Price per pkt., I5c.

Finest Mixed. Price per pkt., $5 c$.

\section{DIANTHUS.}

Dianthus Caryophyllus and its varieties are the much admired Carnation and Picotees. Dianthus Barbatus is the wellknown Sweet William. Dianthus Chinensis and varieties are known as Indian Pinks. Dianthus Heddewigii and Diadematus are splendid sorts,

Dianthus.

\section{DAHLIA.}

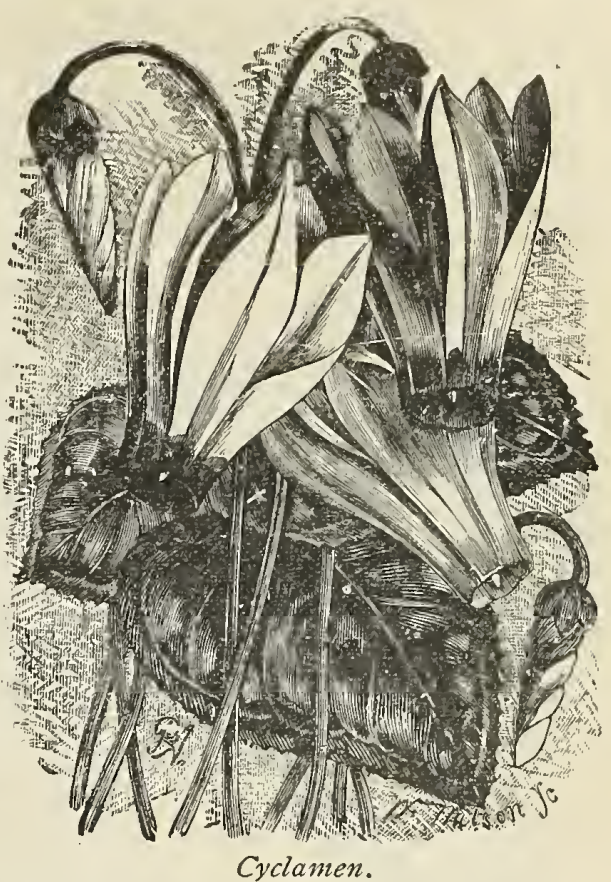

with flowers averaging three inches in diameter, and of the most brilliant colors.

\section{DOUBLE ANNUAL VARIETIES.}

Chinensis. (China or Indian Pink.) Finest double mixed. One foot. Price per pkt., 5c.; per oz., $25 \mathrm{c}$.

Snowflake. Large double fringed flowers. Price per pkt.; $5 \mathrm{c}$.

Heddewigii, fl. pl. (Double Japan Pink.) Very beautiful mixed colors. One foot. Frice per pkt., $5 \mathrm{c}$.

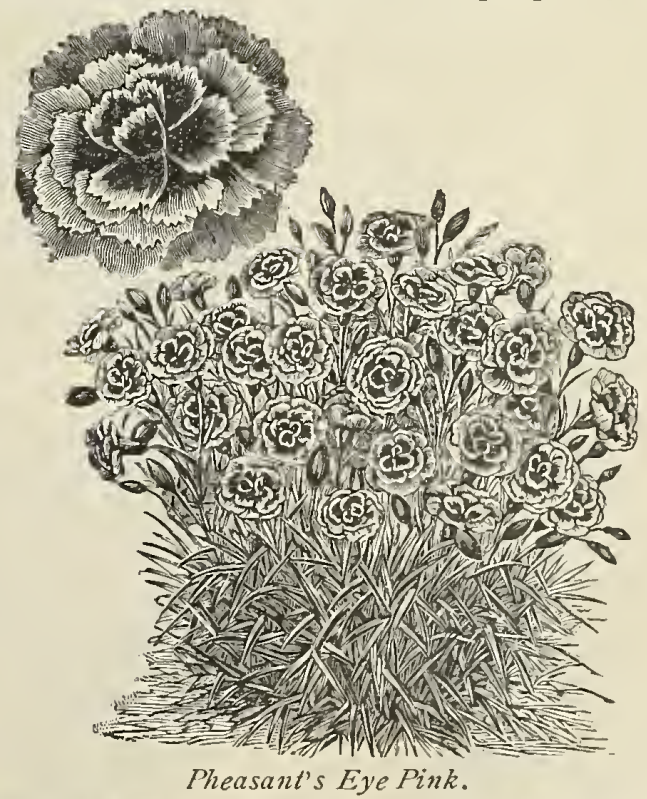

Mourning Cloak or White Frill. (Dianthits Heddewigii.) The flowers are verydark and rich, some maroon color. It has a rich clove fragrance. Halfhardy annual and grows a foot high. Price per pkt., 5c. 
Diadematus Flora Plena (Double Diadem Pink.) A striking variety; luxuriant, but dwarf and compact of growth. Flowers double, comprising all shades of color. Price per pkt., 5c.

Imperialis, fl. pl. (Double Imperial Pink.) Fine nixed. Price per pkt., 5 .

\section{SINGLE ANNUAL VARIETIES.}

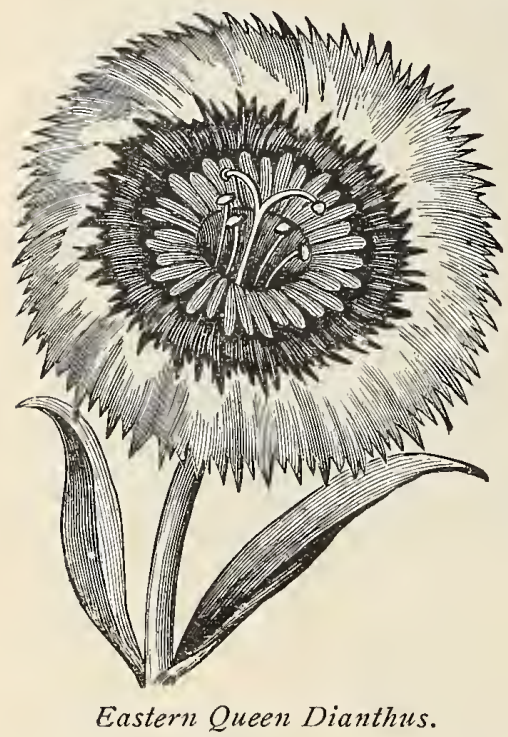

L. a c in i tus. A beautiful fringed variety; various colors. One foot. Price per pkt., $5 \mathrm{c}$. "EasternQueen." The broad bands of mauve upon the paler surface of the petals are very striking and pretty. Price per pkt., 5c.

"Crimson Belle." A rich crimson color, flowers of very large size. Price per pkt., $5 \mathrm{c}$.

Little Gem. A dwarf variety, growing about six inches high. Almostcovered with rosy veined and carmine flowers. Price per pkt., 5 c.

\section{HARDY PERENNIAL VARIETIES.}

Highly valued for the great beauty and fragrance of their flowers. These make splendid bashy plants, from one to two feet high, for permanent beds and borders.

Gardnerianus, fl. pl., Mixed. (Double Hardy Garden Pink.) Large fringed flowers. Price per pkt., $5 \mathrm{c}$.

Plumarius, fl. pl., Mixed (Double Pheasant's Eye Pink.) Double fringed flowers of white, crimson or purple shades, spotted and variegated; ten to twelve inches high. Price per pkt., Ioc.

Scoticus, Mixed. (Scotch Paisley Pink) Large flowering, with fringed edges of various colors. Price per pkt., Ioc.

\section{DIGITALIS.}

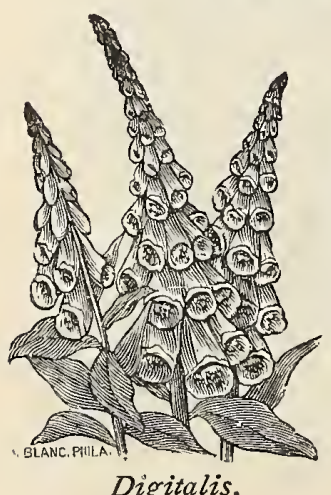

(Foxglove.)

Handsome and highly ornamental plants, of stately growth, bearing long spikes of large, showy flowers, running through shades of white, rose, yellow and purple. Fine for shrubberies and half - shady places. Hardy perennial.

Fine Mixed. Price per pkt., $5 \mathrm{c}$.

Monstrosa. Very long spike with large, novel and beautiful flowers. Price per pkt., Ioc.

\section{ESCHSCHOLTZIA.}

(California Poppy.)

Very attractive plants for beds, edgings or masses; profuse flowering and fine cut foliage. In bloom from June till frost. Hardy annuals. Une foot.

\section{SINGLE VARIETIES.}

California. Sulphur yellow with orange center. Price per plkt., $5 \mathrm{c}$.

Rose Cardinal. Beautiful rose color. Price per pkt., $5 \mathrm{c}$.

Mandarin. Large flowers of a bright scarlet; inner side, rich orange. Price per pkt, $5 \mathrm{c}$.

Finest Mixed. Includes many fine single sorts. Price per pkt., $5 \mathrm{c}$.

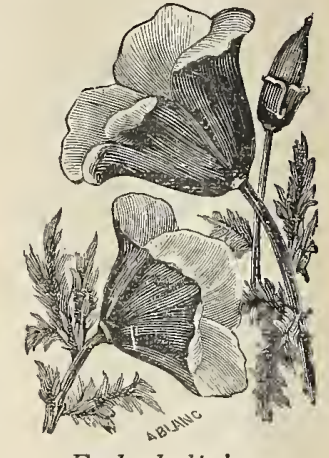

Eschscholtzia.

(Californa Poppy.)
DOUBLE VARIETIES.

Price per pkt., $5 \mathrm{c}$.

Double Yellow. Price per pkt., $5 \mathrm{c}$.

Double Mixed. $\quad$ Price per pkt., $5 \mathrm{c}$.

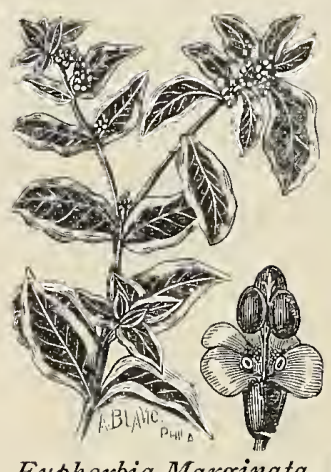

EUPHORBIA.

(Snow on the NTountain.)

Marginata Variegata. It g rows about two feet in height. The large leaves are nearly two inches long, and smal1 at the tops of branches; light green and white mar. gined. A native of our western states and territories. Price per pkt., $5 \mathrm{c}$.

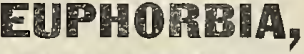

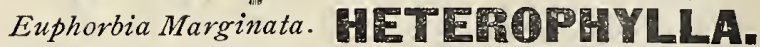

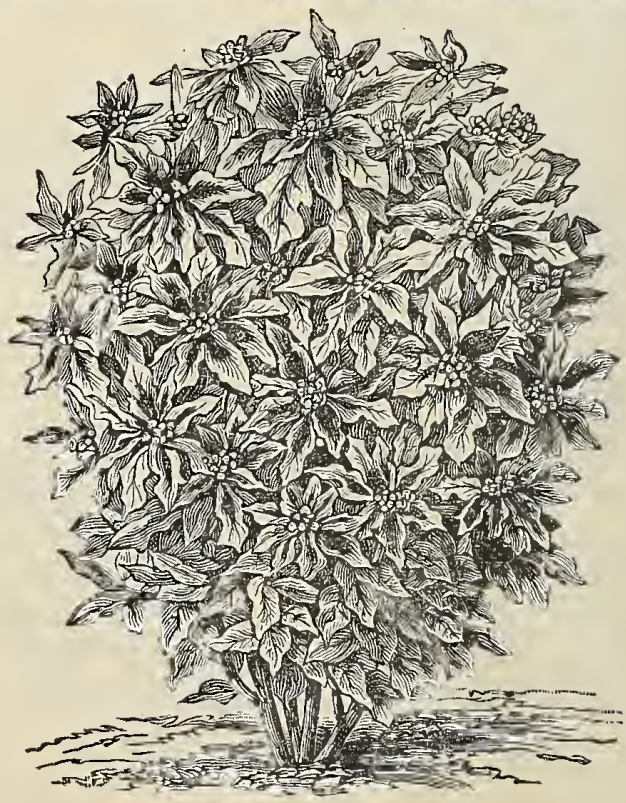

Euphorbia Heterophylla. 


\section{EUPHORBA-Continued.}

Mexican Fire Plant, or Fire on the Mountain. This is a hardy annual of the easiest culture, and resembles in habit and color the hot-house Poinsettia. The plants grow two to three feet high, of branching, bush-like form, with smooth, glossy leaves, which are at first entirely green; but about midsummer clusters of small, white flowers appear on the end of each branch, surrounded by beautiful orange-scarlet bracts, presenting a striking and brilliant combination of colors. Price per pkt., Ioc.

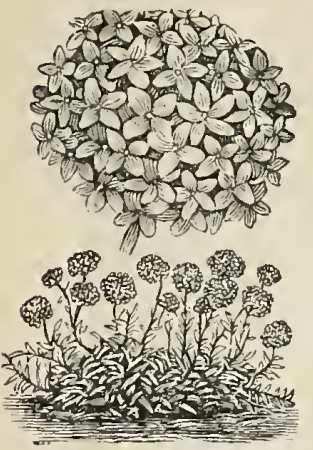

Gaillardia

\section{FEVERFEW.}

Matricaria.

Free-flowering, herbaceous plants, succeeding in any garden soil; blooms until frost; hardy, perennial, blooming the first season if sown early.

Alba Plenissima Double White. Seeds saved from een inches high. Price per pkt., roc.

\section{FORGET-ME-NOT.} (Myosolzs) fine double flowers. Eight-
Showy and universally admired annuals, flowering the first year; among the gayest ornaments of summer flower beds.

Picta Lorenziana. A double variety, blooming propkt., $5 \mathrm{c}$.

Grandiflora Hybrida. Rich crimson and yellow. Price per pkt., $5 \mathrm{c}$.

Fine Mixed. Price per pkt., 5c.

\section{GERANIUM.}

Single Mixed Zonale. Including many varieties. Price per pkt., Ioc.

Double Mixed. Including many varieties. Price per pkt., 25c.

Pelargonium. (Lady Washington) Desirable plants for pot culture; the flowers are borne in clusters, are $\mathrm{I}$ ich and beautifully marked. Price per pkt., $25 \mathrm{c}$.

\section{GILIA.}

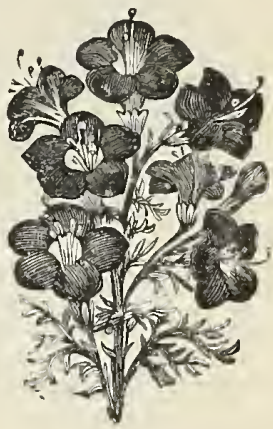

Gilia.

\section{GAILLARDIA.} fusely in large flowers of bright colors. Price per

Hardy annual, grows in almost any situation; profuse bloomers and fine for beds and rockeries.

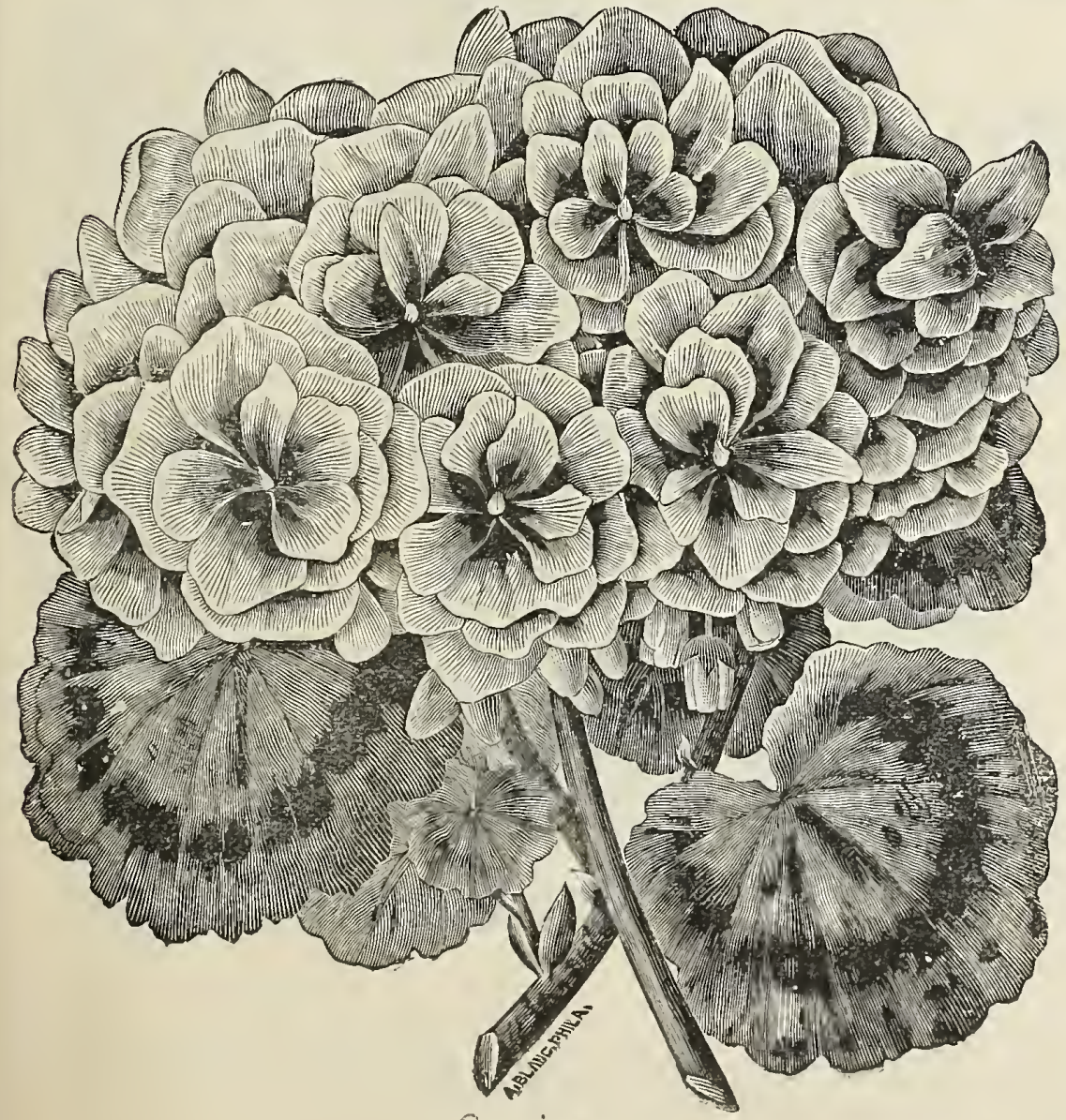

Fine Mixed. Price per pkt., 5 c.

\section{GLOBE A}

"Bachelor's Buttons" These are annuals, forming bushy plants about two feet high and bearing a great many flowers of purple, white, striped, etc. Quite ornamental as $s u m$ er blooming plants, and very desirable "Everlastings."

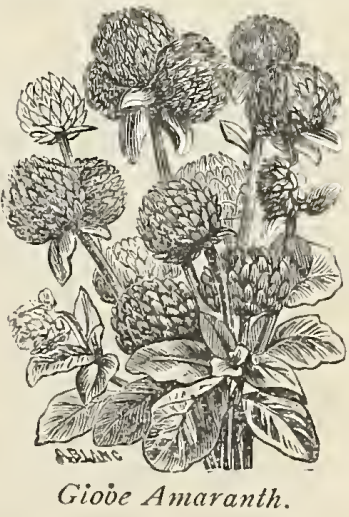

Mixed Colors. Price per pkt., $5 \mathrm{c}$.

White. Price per pkt, 5c, Crimson, Price per plita 


\section{GIFPHALIUM.}

(Edelwerss.)

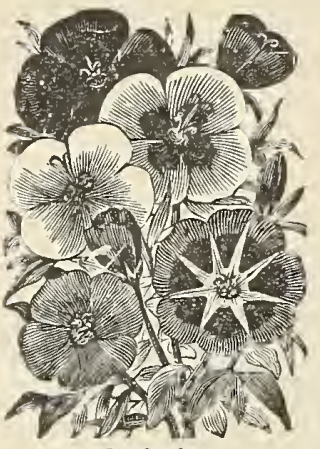

Leontopodium. The famous "Edelweiss" of the Alps. The flowers are star-shaped, of downy texture, and pure white, and are sought after as souvenirs. They retain their natural appearance for years. Very desirable for dried bouquets, etc. Price per pkt., ${ }_{5} \mathrm{c}$.

\section{GODETIA.}

(Satin Flower.)

Very haudsome and showy auuual, of dwarf, compact growth, bearing large flowers of exquisite colors and shades that glisten in the sun light like satin.

Lady Albemarle. Carmine, shading to lilac. Price per pkt., $5 \mathrm{c}$.

Duchess of Albany. Pure satin white. Price per pkt., 5c.

Lady Satin Rose. Glossy rose pink. Price per pkt., $5 \mathrm{c}$.

Finest Mixed. Price per pkt., $5 \mathrm{c}$.

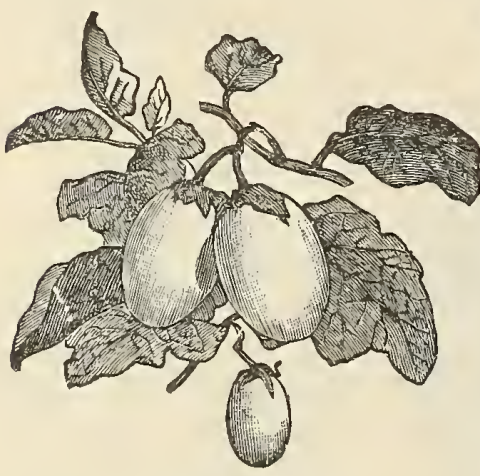

\section{Gourds.}

A very ornamental class of $r$ a $p$ id growing c $1 \mathrm{i}$ mbers. The fruit is of curious shapes, sizes and colors. A11 are hard shelled and will keep indefinitely. Useful for covering fences, brush, or unsightly places.

Nest Egg. A capital nest e g g. Produces a fine white fruit the

shape of an egg. Price per pkt., $5 \mathrm{c}$.

Orange. The fruit resembles an orange in shape and color. Price per pkt., $5 \mathrm{c}$.

Lemon. The fruit resembles a lemon in shape and color. Price per pkt., 5c.

Hercules Club. Club shape. Grows 4 to 6 feet in length. Price per pkt., 5c.

D pper. Its name indicates its use. Price per pkt., $5 \mathrm{c}$.

Dish Cloth. A vegetable dish cloth; the seeds are enveloped in a sponge-like cloth,

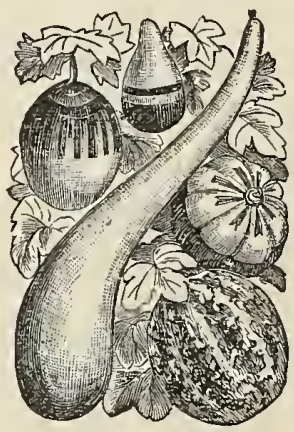

Mixed Gourds. tough and elastic, and admirably answering the purpose of its name. The fruit is about two feet in length. Price per pkt., $5 \mathrm{c}$.

Sugar Trough. This variety grows to a large size. Price per pkt., $5 \mathrm{c}$.

Miniature. Small, green bottomed and bottle-shaped. Price per pkt., 5c.

Bottle. Singularly shaped and resembling a bottle. Price per pkt., $5 \mathrm{c}$.

Fancy and Ornamental. Mixed varieties. Price per pkt., 5 c.

Large. Mixed varieties. Price per pkt., $5 \mathrm{c}$.

\section{GRASSES-0rnamental.}

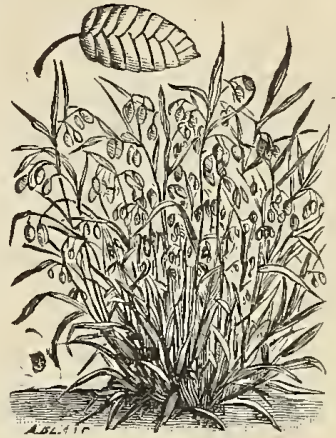

Briza Maxima.

Briza Maxima. (Quaking Grass.) Price perplat, 5c. Bromus Brizæformis. One of the best grasses for dried bouquets. Price per pkt., $5 \mathrm{c}$.

Coix Lachrymæ. (Job's Tears.) Price per pkt., $5 \mathrm{c}$; per oz., $20 \mathrm{c}$.

Eragrostis Eilegans. (Love Grass.) Price per pkt., 5c. Gyneri um Argenteum. (Pampas Grass.) Price per pkt., $5 \mathrm{c}$.

Stipa Pennata. (Feather Grass.) Ind is pensable in grass bouquets. Price per pkt., $5 \mathrm{c}$.

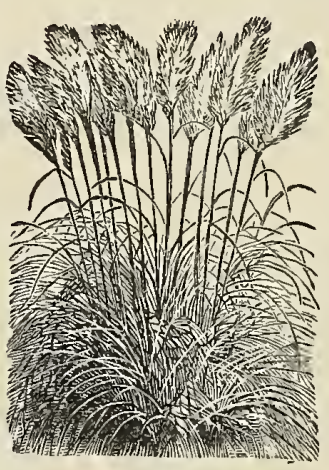

Gynerium Argenteum.
For winter decoration these are very beautiful. For this purpose they should be cut before they are thoroughly ripe. The plauts should be transplanted or thinned out sufficiently to afford space for growth of each as soon as they can be handled; this will allow them to develop their character.

Avena Sterilis. (Animated Oats.) Long, drooping panicles. Price per pkt., 5 c.

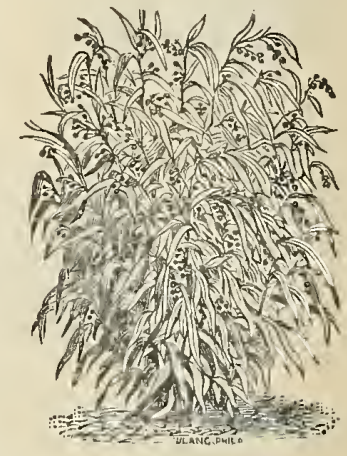

Coix Lachryma.

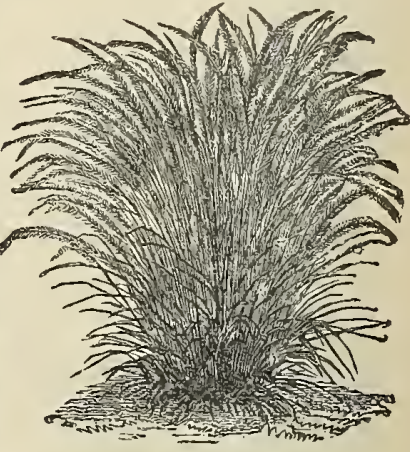

Stipa Pennata.

\section{HYACIRTH BEAN.}

Dolichos.

A beautiful class of quick-growing ornamental climbers, often growing fifteen or twenty feet in a season, producing an abundance of clustered spikes of purple and white flowers, which are followed by exceedingly ornamental seed pods.

Mixed. Price per pkt., 5c. 


\section{HELIANTHUS.}

\section{Sunflower.}

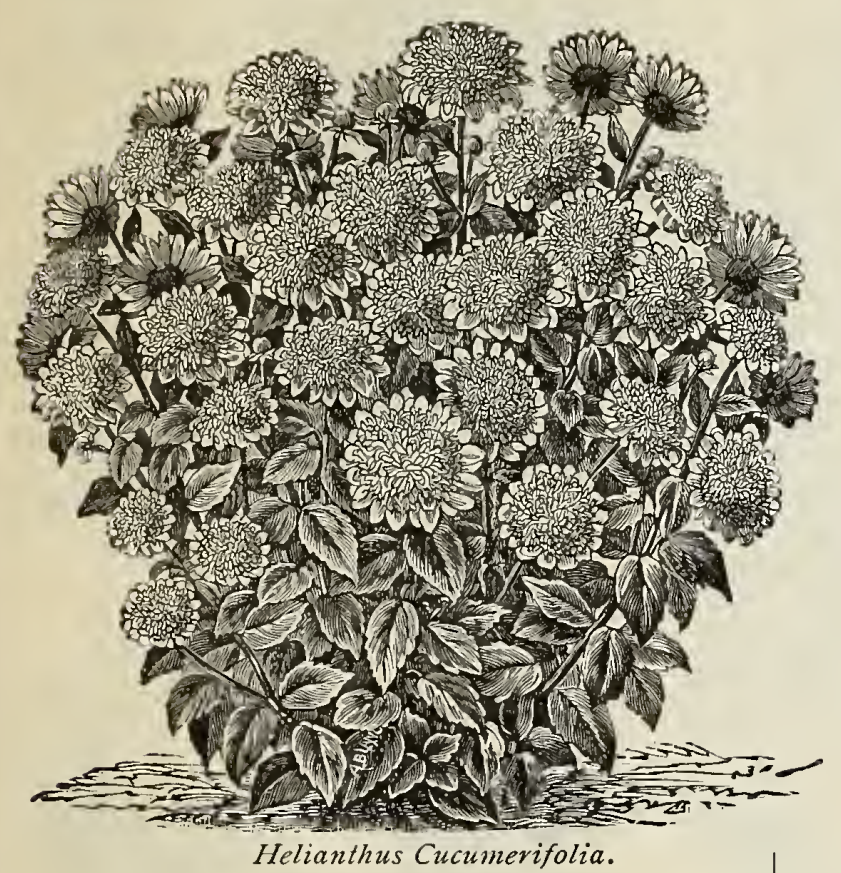

Helianthus Cucumerifolia.

Tall growing plants, with large and showy yellow flowers. Hardy annuals.

\section{SINGLE VARIETIES.}

Miniature. (Cucumerifolia.) Dwarf, bushy habit, profuse in its bloom of bright yellow, black-centered flowers. Price per pkt., $5 \mathrm{c}$.

Stella. Flowers from two to three inches in diameter with black centers, borne on long stems; suitable for cutting. Price per pkt., 5c.

Oscar Wilde. The flowers are small, and consist of a small, black center, surrounded by a row of bright golden petals. Price per pkt., 5c.; per oz., Ioc.

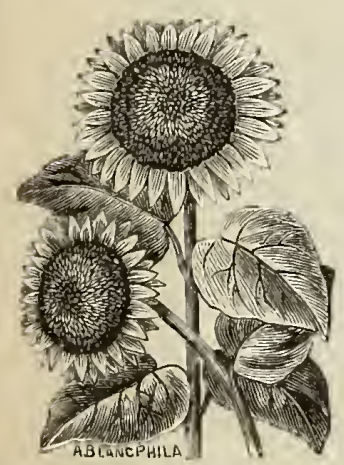

Helianthus Oscar Wilde.

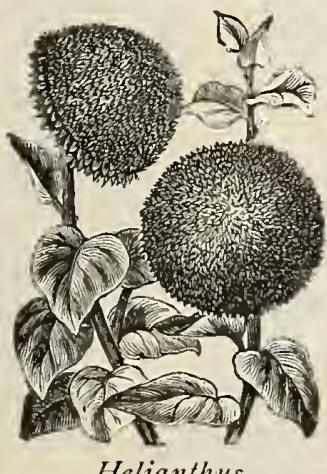

Helianthus

Globosus Fistulosus.
Mammoth Russian. Very rank in its growth, often eight to twelve feet high, bearing single heads measuring from fifteen to eighteen inches in diaméter. Price per pkt., 5c.; :per oz., Ioc.
DOUBLE VARIETIES.

Californicus. Extra large and double Five feet. Price per pkt., $5 \mathrm{c}$.

Globosus Fistulosus. Flowers very large and globular formed. Six feet. Price per pkt., 5c.

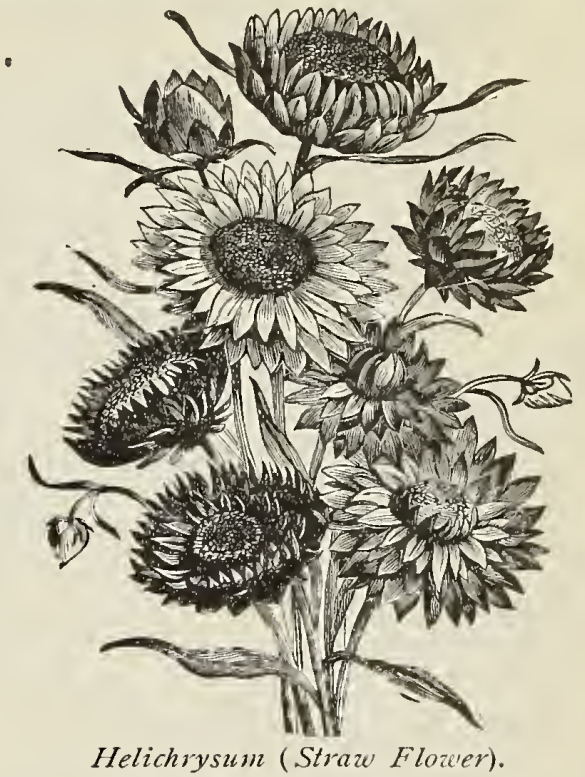

HELICHRYSUM.

Straw Flower.

Bright and attractive summer blooming annuals, of free growth, and producing in abundance large double red, white and yellow flowers, valuable as an "Everlasting."

Large Flowering, Double Mixed. Price per pkt., 5c.

\section{HELIOTROPE.}

A half-hardy perennial, flowering during the whole season; it is a deliciously fragrant and most desirable bouquet flower; also a splendid bedding plant. Seeds sown in the spring will make fine plants for summer blooming.

Mixed. Price per pkt., roc.

\section{Helipterum Sanfordi.}

A very pretty annual, and good border plant of dwarf habit, bearing large globular clusters of bright golden yellow flowers, perhaps the best known of the "Everlastings," and sold in bunches as immortelles. Price per pkt., $5 c$.

\section{HOLLYHOGK.}

For majestic growth and massive beauty the hollyhock stands unrivalled. Flowers very large, perfectly double, and of great variety of color.

Good Mixed. Price per pkt., 5c.

Extra Choice, Double Finest Mixed. Price per pkt., Ioc.

Double Yellow. Price per pkt., Ioc.

Double Crimson. Price per pkt., Ioc.

Double Maroon. Price per pkt., Ioc.

Double Salmon. Price per pkt., roc. 


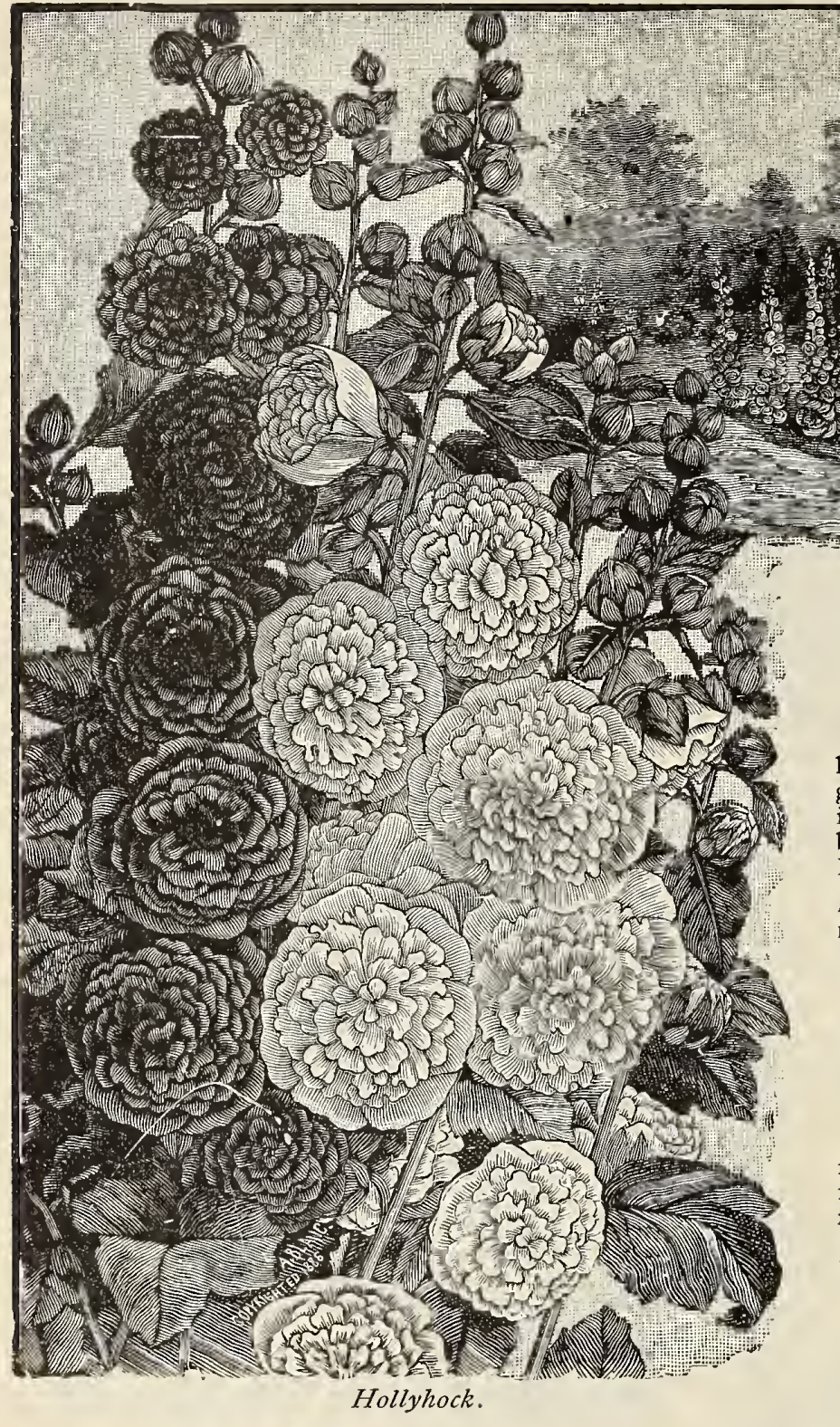

\section{IPOMEA.}

This is a rapid and luxuriant summer climber, profuse in its blooming of large,

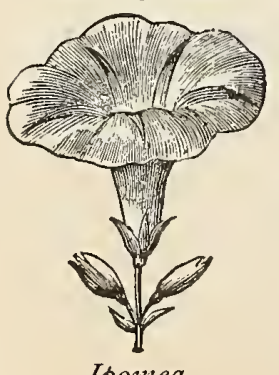

invaluable for covering

walls, trellises, arbors

or stumps of trees.

Coccinea. (Star Ipomea.) Small scarlet flower. Price per pkt., $5 \mathrm{c}$.

Bona Nox. (Evening Glory or Good Night.) Large, pure white, fragrant flowers. Price per pkt., Ioc.

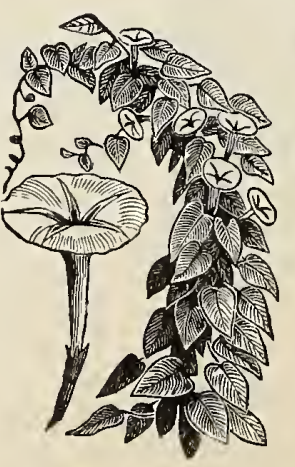

Ipomea Bona Box.

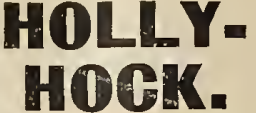

Continued.

Canary Yellow.

Price per pkt., Ioc.

White. Price per pkt., Ioc.

Mammoth

Fringed Alleghany Mixed.

Price per pkt.; IOc.

\section{Honesty.}

Silvery, transparent seed vessels, of beautiful effect for dried bouquets. Price per pkt., $5 \mathrm{c}$.

\section{IGE PLANT.}

A very pretty little trailing plant, the leaves of which are covered with crystalline globules, thus giving it the appearance of being coated with ice. Half-hardy annua1.

Mesembryanthe $=$ mum Crystallinum.

Price per pkt., $5 \mathrm{c}$.

\section{Impatiens Sultani.}

A beautiful decorative plant, producing cherry-red, waxy flowers continuously.

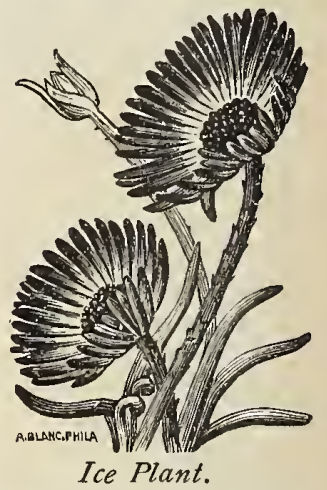

Zanzibar or Sultana's Balsam. Price per pkt., Ioc.

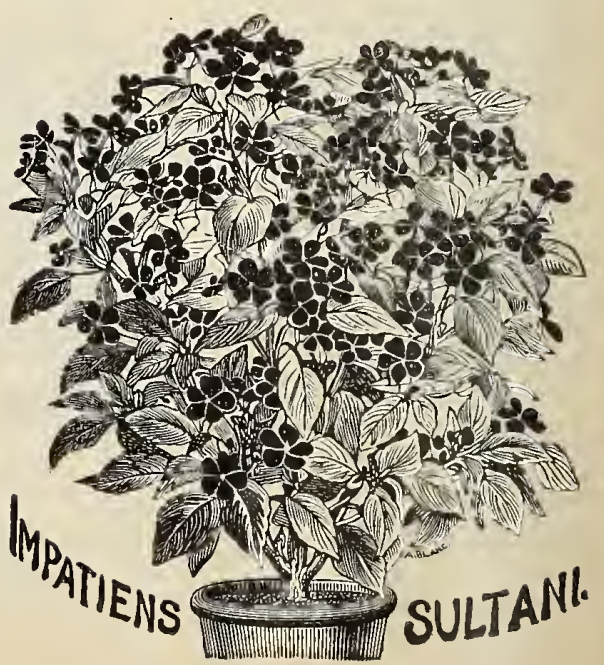




\section{IPOMEA-continued.}

Noctiflora. (Moon Flower.) The flowers, which expand in the evening, are white, from five to six inches in diameter, and emit a Jasmine-like odor; the vines grow very rapidly, attaining a height of twenty-five feet. Price per pkt., Ioc.

\section{LARKSPUR ANNUAL.}

\section{Delphinium.}

A beautiful genus of plants, very dwarf and compact habits, possessing almost every requisite for the adornment of the garden, blooming in the greatest profusion, and of every variety of the most brilliant colors.

Emperor. Of bushy habit, remarkably floriferous, witl beautiful dark blue, red-striped and tri-colored flowers. Price per pkt., 5c.

Double Dwarf Rocket Mixed. Price per pkt., 5c.

Tall, Double Rocket Mixed. Price per pkt., $5 c$.

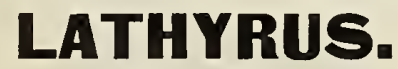

\section{Everlasting Pea.}

Showy, free-flowering plants, growing in any common soil; very ormamental on trellis work, old stumps, or for covering fences or walls. Hardy perenuials.

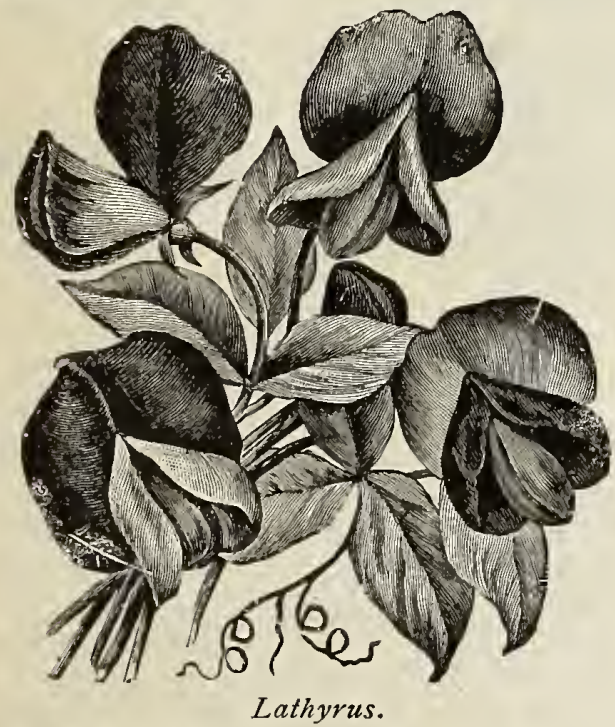

Latifolius, White. Price per pkt., Ioc. Latifolius, Scarlet. Price per pkt., roc. Mixed. Price per pkt., I5c.

\section{LINUM. \\ Flowering Flax.}

A showy bedding plant of the flax family, having brilliant flowers of various colors, borne on slender stems, with fine foliage. Does well in any light garden soil. Hardy annual.

Grandiflorum Coccineum. Bright scarlet. Price per pkt., 5 c.

Flavum. Beautifnl golden yellow. Price per pkt., $5 c$. Mixed. Price per pkt., 5 c.

\section{LOBELIA.}

The following dwarf and trailiug varieties of this popular and beautiful flowering plant will be found most desirable for pot culture, edgings, hanging baskets, etc., blooming profusely from June to November. Half-hardy annual.

Erinus Varieties for Baskets, Vases, Etc. Six to nine inches.

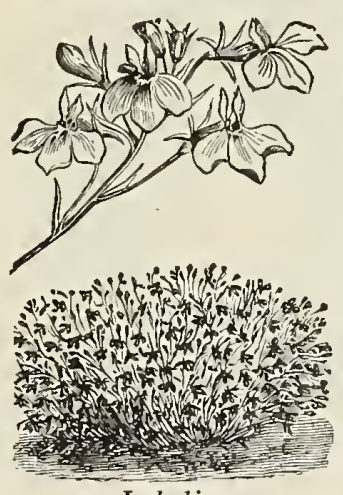

Alba. Pure white. Price per pkt., 5c.

Speciosa. Bright blue. Price per pkt., 5c.

Aracilis. Light blue; long, slender, trailing stems Price per pkt., 5c.

Mixed. Contains many sorts. Price per pkt., $5 \mathrm{c}$.

Compacta Varieties for Edgings, Etc. Four to six inches.

White Gem. Pure white. Price per pkt., 5c.

Lobelia.

Crystal Palace. Dark blue; fine for bedding. Price per pkt., $5 \mathrm{c}$.

Prima Donna. Dwarf, bnshy plants, with rich velvety crimson maroon flowers. Price per pkt., Ioc.

Mixed Varieties. Price per pkt., 5c.

\section{MARIGOLD.}

Very effective, half-hardy anuual; very showy in the garden, and continning in flower from early in the summer till frost. The African, the tallest, is the most

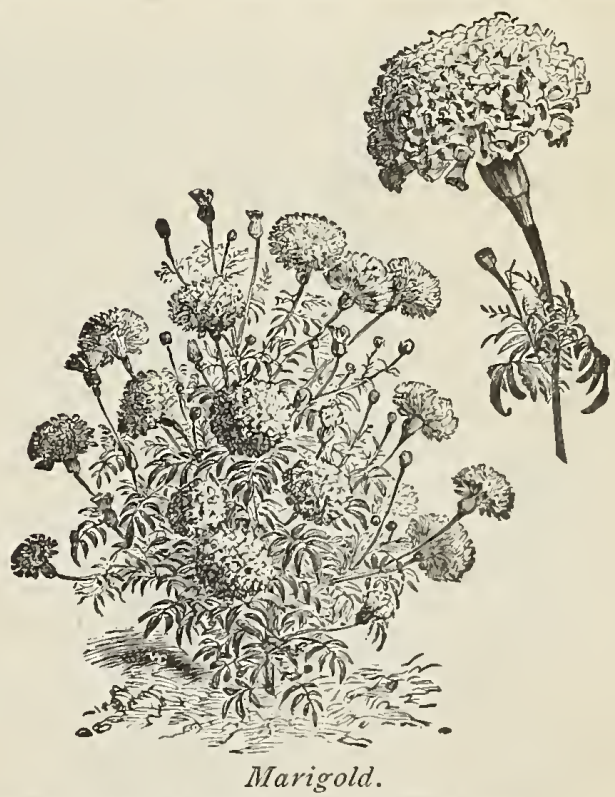

effective in large beds, mixed flowers and shrubbery borders. The Dwarf Freuch makes splendid compact edging for beds and borders.

Double French Dwarf Mixed. Price per pkt., 5c.; per oz., 5oc.

African Double Mixed. Tall-Orauge brown., Price per pkt., 5c.; per oz., $40 \mathrm{c}$.

Eldorado. Tall-Large flowers in all shades of ye1low. Price per pkt., 5c.; per oz., 5oc. 


\section{LUPINS.}

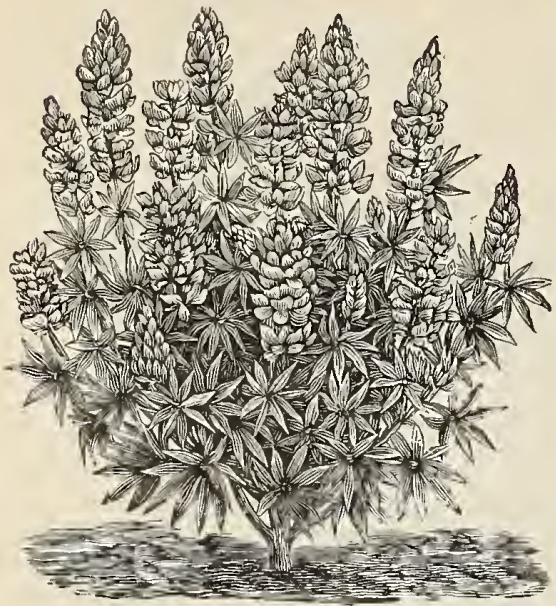

Lupins.
A we 11

known genus ; very cons picu ousand showy. Ma n y of the varieties are of a stately, robust growth, which 'm a ke them valuable for mixed flowers a nd sh r u b bery borders. Hardy annual.

Affinis. Blue, white and purple. Per pkt., 5c.

Crookshanki. Blue, white and yellow. Per pkt., 5c.

Hybrida Atrococcineus. Scarlet and white. Price per pkt., $5 \mathrm{c}$.

Mixed Colors. Price per pkt., $5 \mathrm{c}$.

\section{MAURANDIA.}

These beautiful sumner climbers cannot be too highly recommended, whether for the adornment of the conservatory or greenhouse, or for trailing on trellis work. Blooms the first season from seed.

Barclayana. Rich violet. Price per pkt., Ioc.

Finest Mixed. Price per pkt., Ioc.

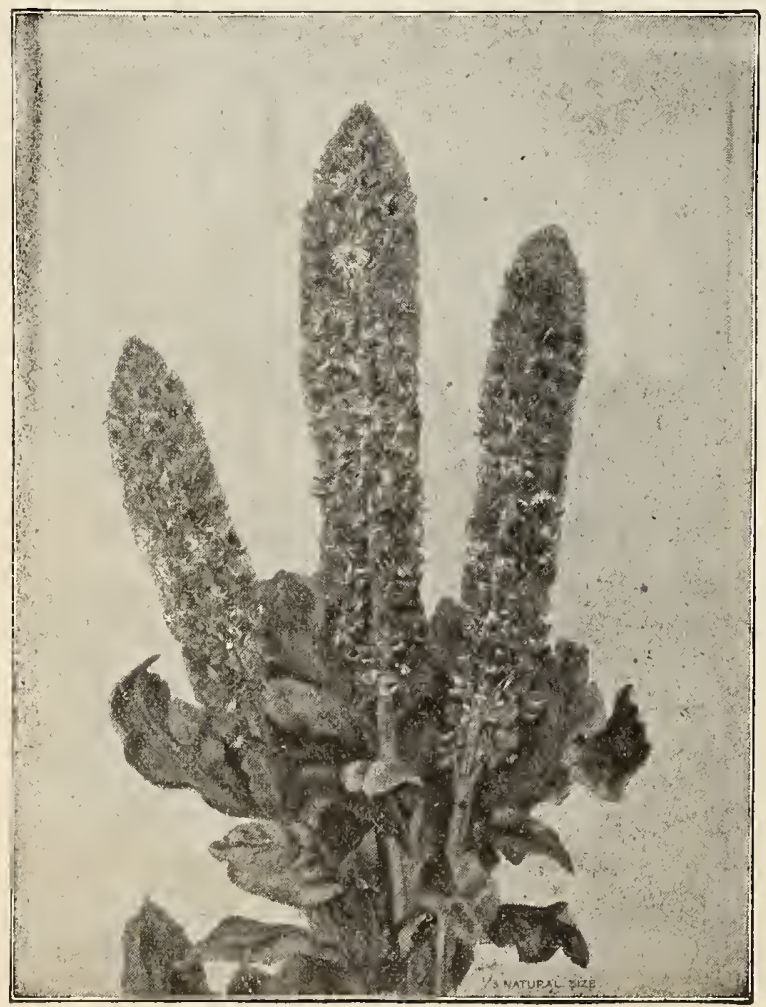

Defiance Mignonette.

\section{MIGNONETTE.}

A well-known favorite, highly esteemed for its fragrance; essential in every garden. If it is well thinned out as soon as the plants are large enough, they will grow stronger and produce larger spikes of bloom. Hardy annual.

Reseda Odorata. Improved, large flowering. Price per pkt., $5 \mathrm{c}$; per oz., $15 \mathrm{c}$.

Parson's White. A distinct, almost white variety. Price per pkt., 5c.

Hybrid Spiral. Produces flower spikes from eight to ten inches in length. Price per pkt., $5 \mathrm{c}$.

Machet. A dwarf, bushy, Frencin variety, excellent for pot culture. Price per pkt., 5c.; per oz., $50 \mathrm{c}$.

Bird's Mammoth. Flower spikes of immense size, often measuring eight or nine inches in length. Price per pkt., IOc.

Allen's Defiance. When grown under favorable conditions its spikes will be of remarkable size-from twelve to fifteen inches long. Price per pkt., I5c.

\section{MIMOSA.}

Sensitive Plant.

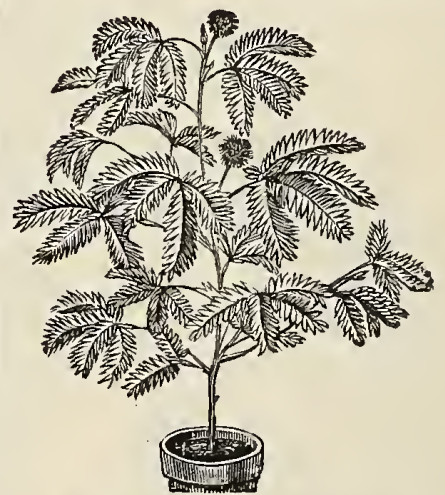

Mimosa (Sensitive Plant).
A very interesting and curious plant, its leaves closing if touched or shaken.

Pudica. Price per pkt., 5c.

\section{Mimulus. \\ Monkey Flower.}

The mimulus is a be a u if $u 1$, tenderlooking plant, with almost transparent branches. Succeeds best in moist, shady situations; fine for baskets under shelter, verandas or vases, and for culture in the house.

Mixed. Blotched and spotted hybrid. Price per pkt., 5c.

Moschatus. (Musk Plant). Foliage emits a strong musky perfume; flowers, canary yellow. Price per pkt., roc.

\section{Mormordica.}

Luxuriant annual climbers, with ornamental foliage, fruit golden yellow, warted, and when ripe, opens, showing the seeds and its brilliant carmine interior. Ten to fifteen feet.

Mormordica $B$ a Is a mina. Apple-shaped fruit. Price per pkt., $5 \mathrm{c}$.

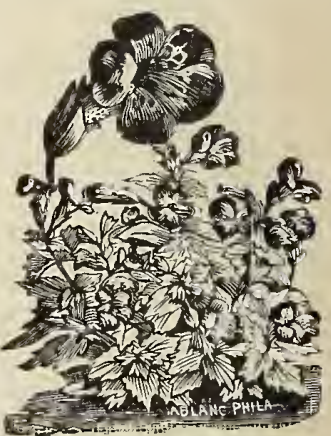

Mimulus.

(Monkey Flower).
Charanta. Pear-shaped fruit. Price per pkt., $5 \mathrm{c}$.

\section{MORNING GLORY.}


MARVEL OF PERU.

Foner O'clock.

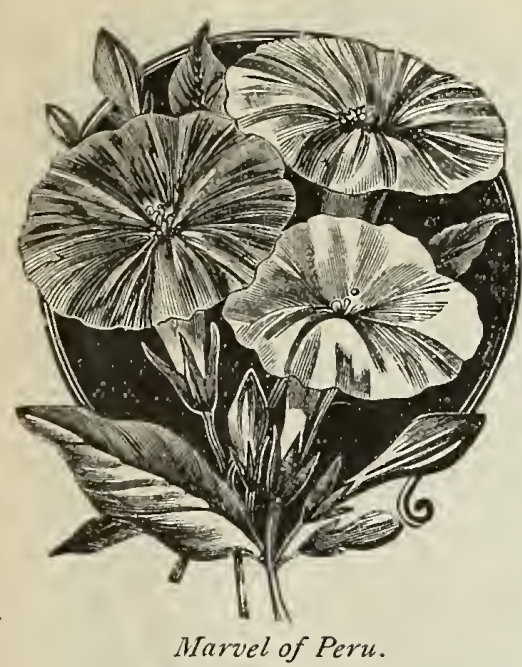

This grows $\mathrm{two}$ feet in height, we 11 b r a $\mathrm{n} \mathrm{ch}$ e d, bright foliage, fragrant flowers and desirable colors. Set plants two feet a part. It is really a good plant, and makes a nice summer hedge. Seeds should be planted in the open ground where $\mathrm{the}$ plants are desired.

Marvel of Peru or Four O'clock. Mixed. Price per pkt., $5 \mathrm{c}$.

Marvel of Peru. Variegated. Price per pkt., 5c.

\section{MYOSOTIS.}

Forget-1ne-not.

A well-known plant, bearing clusters of star-like flowers, best adapted to moist situations, though growing in almost any soil. Half-hardy perennial.

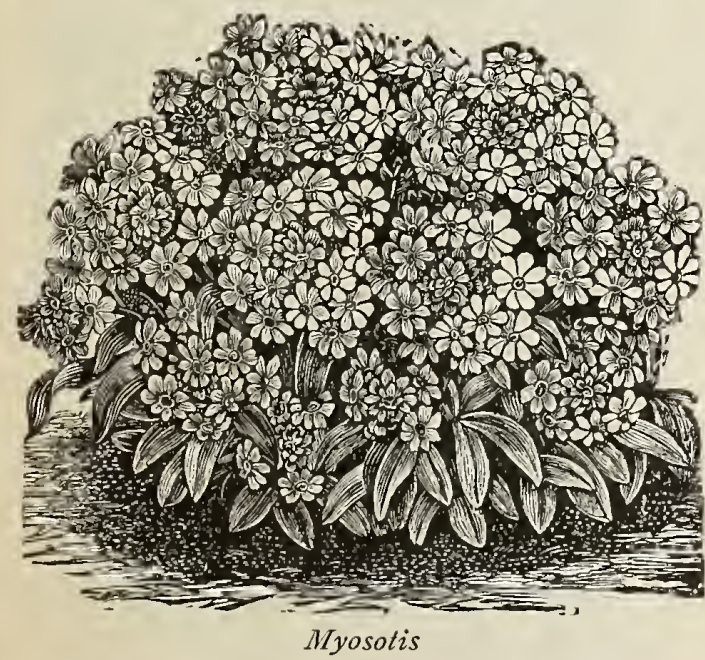

Alpestris Corulæ. Bright blue. Price per pkt., 5c. Alpestris Alba. Pure white. Price per pkt., 5c.

Palustris. Large flowering, dark blue; (the true forget-me-not). Price per pkt., roc.

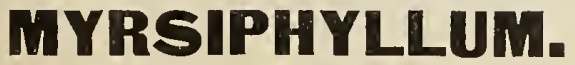

(See Smilax.)

\section{NASTURTIUM.}

Tropcolum.

Plants of great beauty, blooming throughout the summer and fall, and in the greenhouse during winter. The tall varieties make good covering for walls and trellises. The compact growth and rich colored flowers of the dwarf varieties make them desirable for

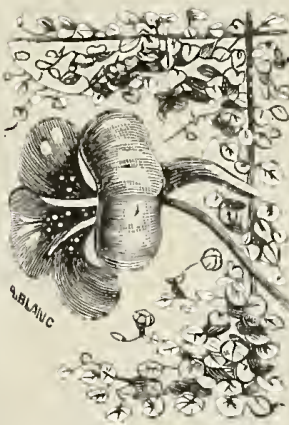

Nasturtium, Tall. bedding plants. They succeed best in light soil, not very rich.

\section{TALLL VARIETIES.}

Crimson. Rich color. Price per oz., 2oc.; per pkt., 5c.

Pearl. White. Price per oz. 20c.; per pkt., $5 \mathrm{c}$

Rose. Beautiful shade. Price per oz., 2oc.; per pkt., 5c.

Scarlet. Brilliant red. Price per oz, 20c.; per pkt., $5 \mathrm{c}$.

Yellow. Spotted crimson. Price per oz., 20c.; per pkt., $5 \mathrm{c}$.

Mixed. All colors. Price per $1 \mathrm{~b} ., \$ 1.25$; per oz., $15 \mathrm{c}$.; per pkt., $5 \mathrm{c}$

\section{DWARF VARIETIES.}

Aurora. Salmon rose, shading from pink to carmine. Price per oz., 2oc.; per pkt., $5 \mathrm{c}$.

Beauty. Yellow, striped with red. Price per oz., 20c.; per pkt., 5c.

Cloth of Gold. Scarlet flowers with golden yellow foliage. Price per oz., 2oc.; per pkt., 5c.

Empress of India. Very dark green foliage; flowers bright crimson. Price per oz., 20c.; per pkt., 5c.

Crystal Palace Gem. Sulphur yellow, spotted maroon. Price per oz., 2oc.; per pkt., 5c.

King of Tom Thumbs. Intense scarlet. Price per oz., 2oc.; per pkt., $5 \mathrm{c}$.

King Theodore. Deep maroon flowers and dark foliage. Price per oz., 20c.; per pkt., $5 \mathrm{c}$

Lad y B i r d. Golden yel low, striped and spotted with bright red. Price per oz., 20c.; per pkt., $5 \mathrm{c}$.

Pearl. Creamy white. Price per oz., 20c.; per pkt., $5 \mathrm{c}$.

Rose. Dark pink. Price per oz., 2oc.; per pkt., $5 \mathrm{c}$.

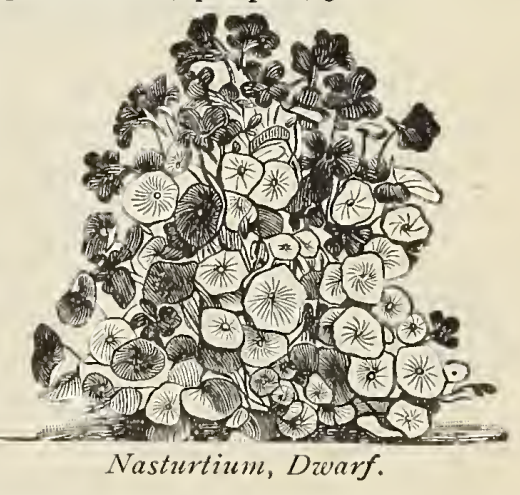

Golden King. Pure bright yellow. Price per oz., 2uc.; per pkt., $5 \mathrm{c}$.

Mixed. A11 colors. Price per $1 \mathrm{~b}, \$$ I.5o; per oz., $15 \mathrm{c}$.; per pkt., $5 \mathrm{c}$.

\section{LOBBIANUM NASTURTIUMS.}

The brilliance and profusion in blooming of the Lobbianum varieties render them superior for greenhouse or conservatory decoration in winter; also for trellises, arbors and vases, etc., in summer; half-hardy annuals. Six to ten feet. 


\section{LORBIANUM NASTURTIUMS-Continued.}

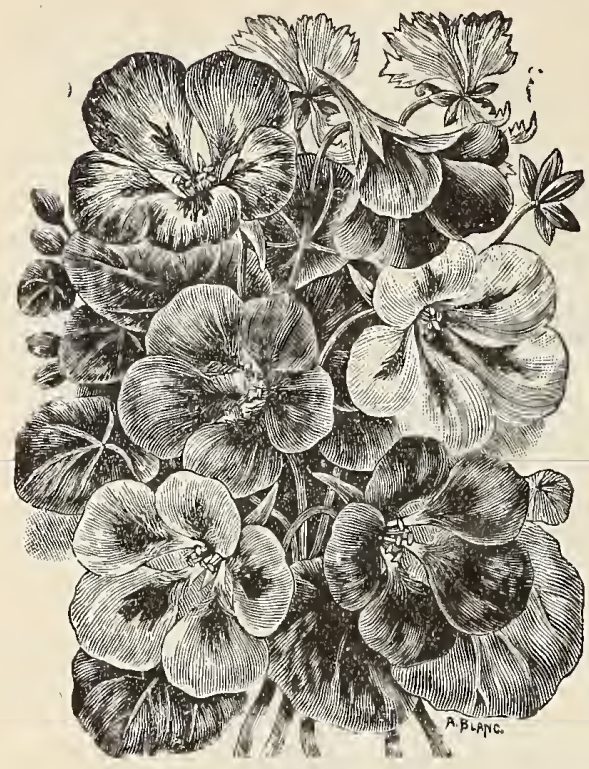

Nasturtiums.
Brilliant, Rich scarlet. Price per pkt., $5 \mathrm{c}$.

Spitfire. Crimson. Price per pkt., 5c.

Finest Mixed. Price per oz., 25c.; per pkt., $5 \mathrm{c}$.

Nasturtium P e r e gr $\mathbf{r}=$ num. (See Canary Bird Hlower.) Price per pkt., $5 \mathrm{c}$.

\section{Nigella.}

Love in a Mist or Devil in a Eush.

A compact, free-flowering plant, with finely cut foliage, curious looking flowers and seed pods; of easy culture, growing in any garden soil. Hardy annual. One foot.

Damascena. Blue and white mixed. Price per pkt., $5 \mathrm{c}$.

\section{NICOTIANA.}

Affinis. A very ornamental plant with long, tubular white flowers, deliciously fragrant, and as easily grown as the common tobacco. Price per pkt., $5 \mathrm{c}$.

Giant Red Flowered. The foliage is luxuriant; surmounted with crimson flowers. They grow rapidly, and continue until cut down by frost. Price per pkt., 5c.

\section{NEMOPHILA.}
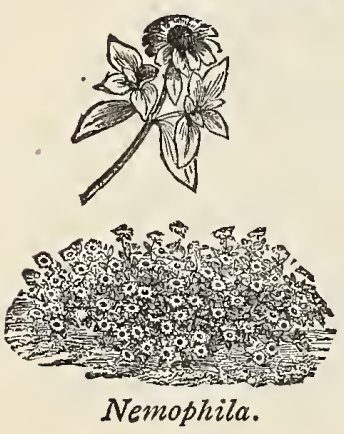

A charming class of dwarf - growing, freeflowering hardy annuals, of spreading habit.

Marginata. Azure blue, edged with white. Price per pkt., 5c.

Finest Mixed Colors. Price per pkt., 5c.

\section{PORTULACA.}

These brilliant and popular hardy annuals are of the easiest culture, luxuriating in an exposed, sunny situation, and producing throughout the summer their various colored flowers in the greatest profusion.

Golden Striped. Straw color with golden or orange stripes. Price per pkt, $5 \mathrm{c}$.

Alba. Clear white. Price per pkt., 5c.

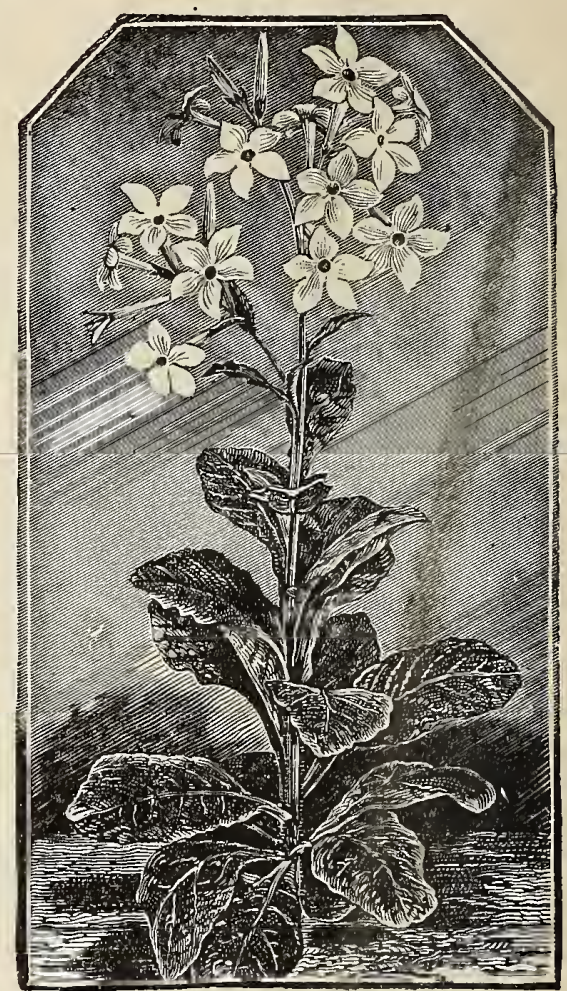

Nicotiana Affinis.
Pink. A delicate pink shade. Price per pkt., 5c.

Splendid Mixed Single. Price per pkt., 5c.

Large Flowering, Double Mixed. Flowers perfectly double, making a gorgeous display, remaining open all day. Price per pkt., Ioc.
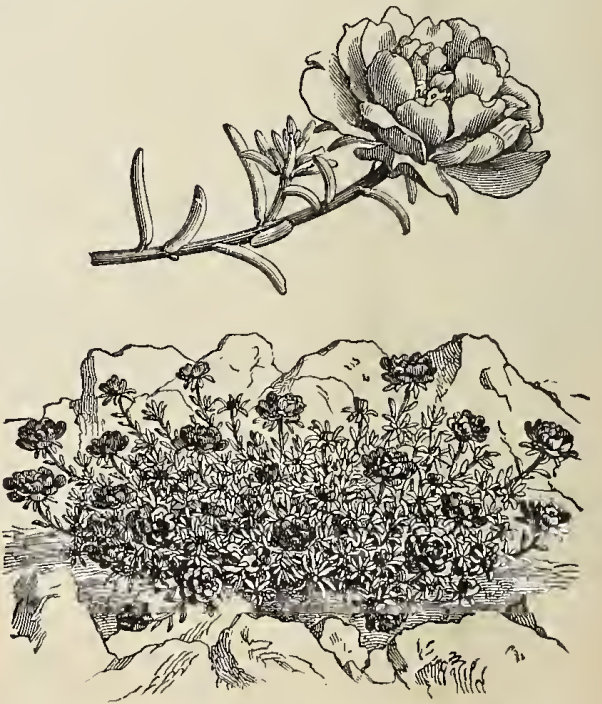

Portulaca; Large Flowering, Double Mixed. 


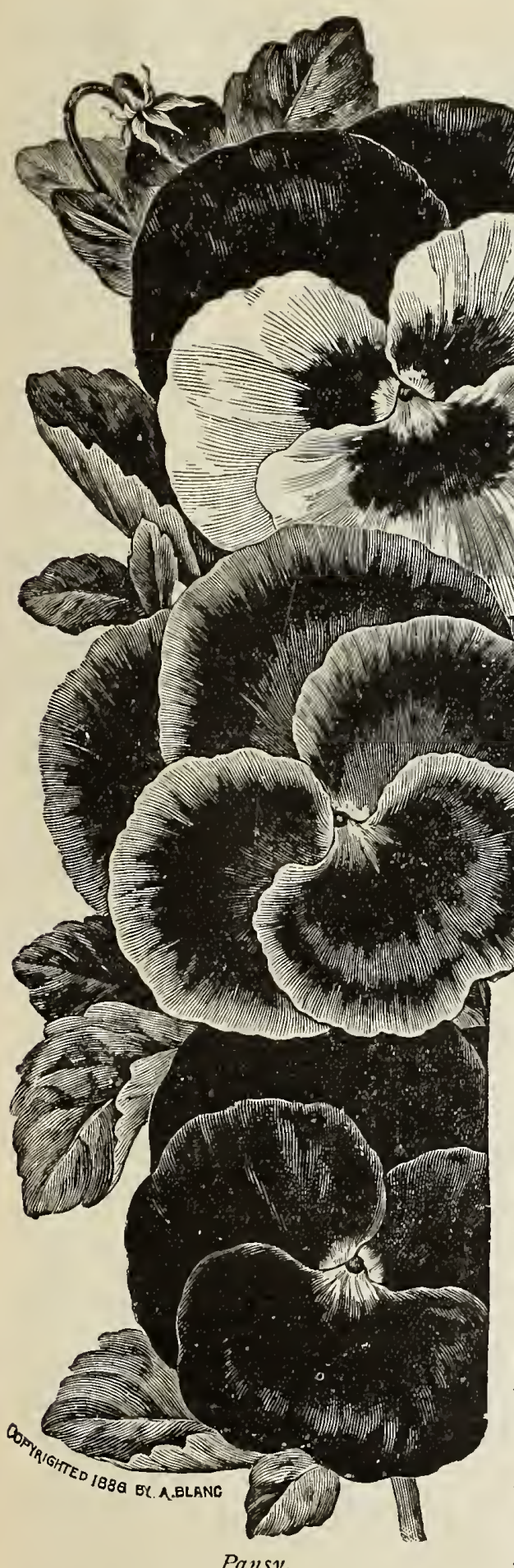

Pansy.

Mixed. Good quality. Price per pkt., 5c.

Mixed Seeds. English grown. Price per pkt., Ioc.

Mixed Seeds. German grown. Price per pkt., 15 $_{5}$.

Giant Trimardeau. Extra large and fine. Mixed. Price per pkt., I5c.

Large Belgian or Butterfly. Mixed. Price per pkt., $25 \mathrm{c}$.

King of the Blacks. Almost coal black. Price per pkt., $5 \mathrm{c}$.

Emperor William. Ultramarine Blue, with purple violet eyes. Price per pkt., $5 \mathrm{c}$.

Peacock Blue. Rich velvety blue, white edge. Price per pkt., Ioc.

Light Blue. Sky blue. Price per pkt., Ioc.

Violet. With white border. Price per pkt., Ioc

Bugnot's Superb Striped and Blotched. Extra and very showy. Price per pkt., I5c.

Yellow Margined. Beautiful color, with margin or belt of yellow. Price per pkt., Ioc.

Mahogany Colored. A rich bronzy red. Price per pkt., Ioc.

Bronze. Copper colored. Price per pkt., roc.

Red Victoria. Bright coppery colors, but not strictly red. Price per pkt., roc.

Pure Yellow. Fine for bedding. Price per pkt, Ioc.
White. Sometimes slightly marked with purple. Price per pkt., roc.

Odier or Large Eyed. Dark spots on each petal, and large eyes. Price per pkt., roc. 


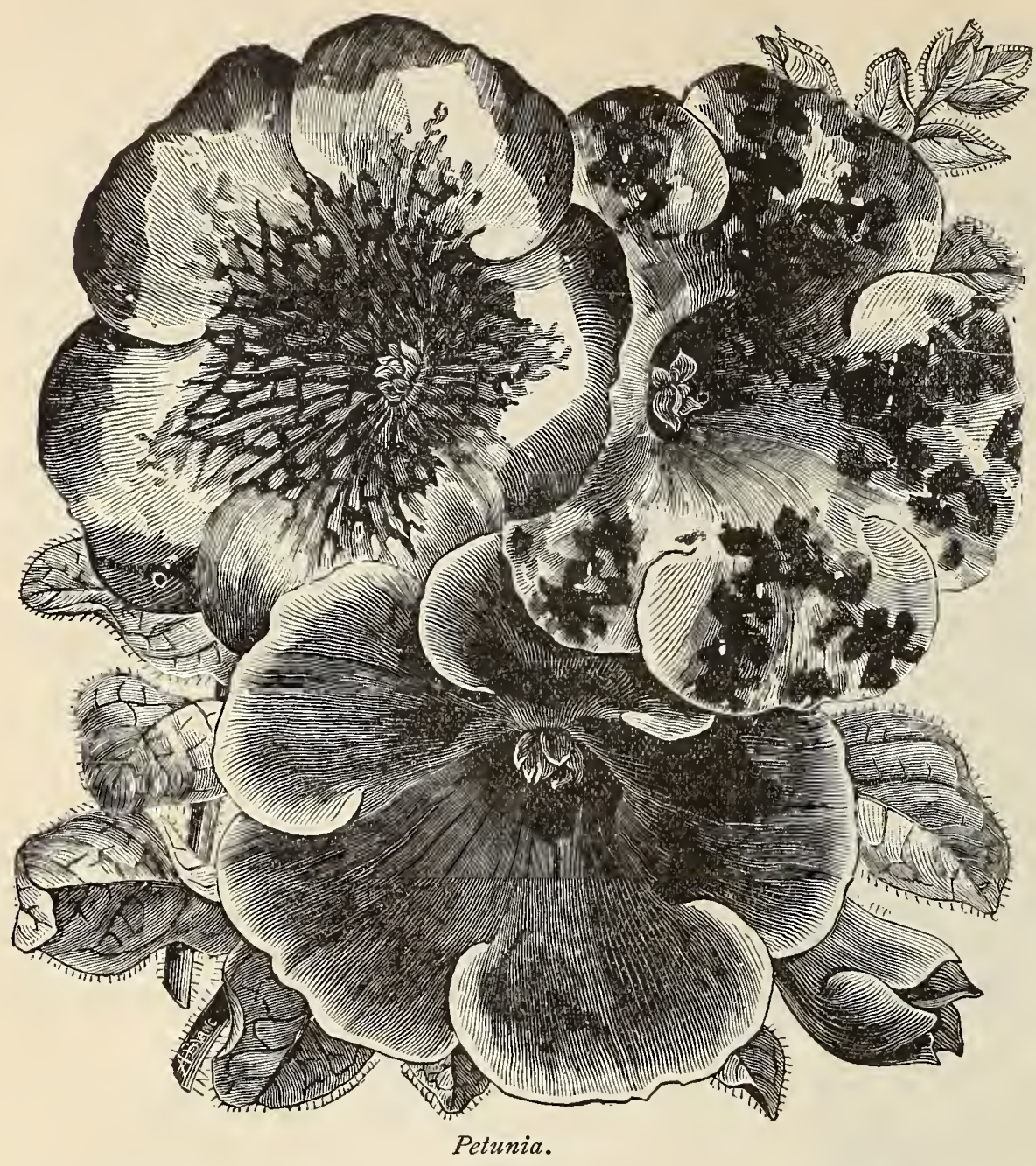

\section{PETUNIA.}

The brilliancy and variety of its colors, combined with the duration of its bloomiug period render it invaluable. The plants are of easy culture and thrive well in any good garden soil.

Fine Mixed. Price per oz., 75c. Price per pkt., 5 c.

Extra Choice $M$ ixed. Largest flowered. Price per pkt., Ioc.

California Giants. Striped and blotched; extra fine mixed. Price per pkt., $25 \mathrm{c}$.

Striped and Blotched. Large flowered, extra. Price per pkt., Ioc.

Large Single Fringed. Blotched and striped; large flowering, mixed. Price per pkt., 25c.

Finest Double. Beautiful shades of $\mathrm{crimson}$, white, rose, striped and blotched. Price per pkt., $25 \mathrm{c}$.

\section{PHLOX.}

This splendid genus of plant is unrivaled for richness of color, profufusion of blossoms, length of duration in bloom, and whether in clumps or masses, looks equally beautiful

Phlox Drummondi. Mixed. Price per oz., 5oc.; per pkt., 5c.

\section{LARGE FLOWERING PHLOX.}

The large-flowering kinds are a decided improvement on the Drummondii, producing flowers twice the size of the latter, with the most brilliant colors.

Alba. Pure white, extra large. Price per pkt., 5c.

Brilliant Scarlet. Price per pkt., $5 \mathrm{c}$.

Rosy Carmine. White Eye. Price per pkt., 5c

Rosea Pink. White Fye. Price per pkt., $5 \mathrm{c}$.

Vivid Crimson. Large White Eye. Price per pkt., 5c. Large Yellow. A very fine color. Price per pkt., 5c. Splendid Mixed. Includes all of the above, and many other shades and colors. Price per pkt., Ioc.

Star of Quedlinburgh. Star-shaped Phlox of dwarf habit, with very pretty flowers, mixed colors. Price per pkt., Ioc.

\section{DOUBLE - FLOWERING PHLOX.}

Flowers are double and semi-double, and last much longer than those of the Single Phlox. The white is especially valuable as a cut flower.

Double White. Price per pkt, roc.

Double Scarlet. Price per pkt., Ioc.

Double Mixed. Price per pkt., Ioc.

\section{DWARF PHLOX.}

\section{Phlox Drummondii Nana Compacta.}

These are the best for ribbon bedding or borders. The plants grow very symmetrically in neat little bushes about eight inches ligh; covered with flowers during the whole summer and fall, as large as those of the Drummondii, and as easy to grow. 


\section{DWARF PHLOX.}

\section{Continued.}

Snowball. Flowers pure white; the plants resemble large snowballs wlien in full bloom. Price per pkt., IOc.

Fireball. Glowing, brilliant scarlet. Price per pkt., Ioc.

Dwarf Phlox, Mixed. Price per pkt. roc.

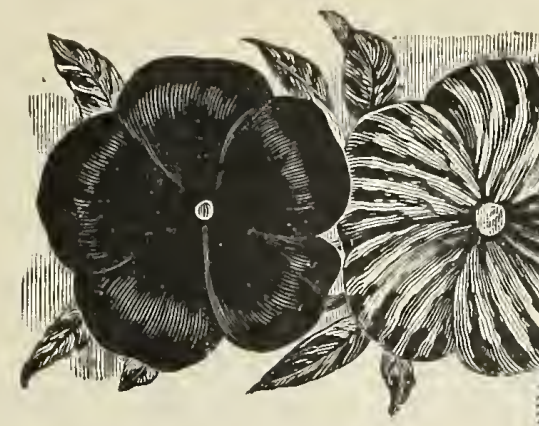

PHYSALIS FRANCHETI.

Chinese Lantern Plant.

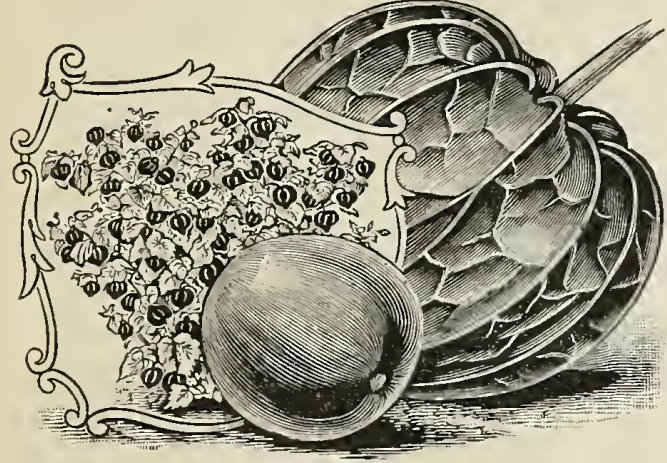

Physalis Francheti.

It is of striking appearance, producing bright red fruits, which are enclosed in a. semi-transparent calyx about two inches in length and is bright orange-scarlet in color when nearing maturity. Price per pkt., roc.

\section{Polyanthus.}

\section{Primula Elatior.}

Showy, early spring, freeflowering plants, fine for either pot or outdoor culture; hardy perennials. Nine inches.

Polyanthus, English. The best single, all colors mixed. Price per pkt., $5 \mathrm{c}$. Duplex. Double hose-in-hose, mixed. Price per pkt., I5c.

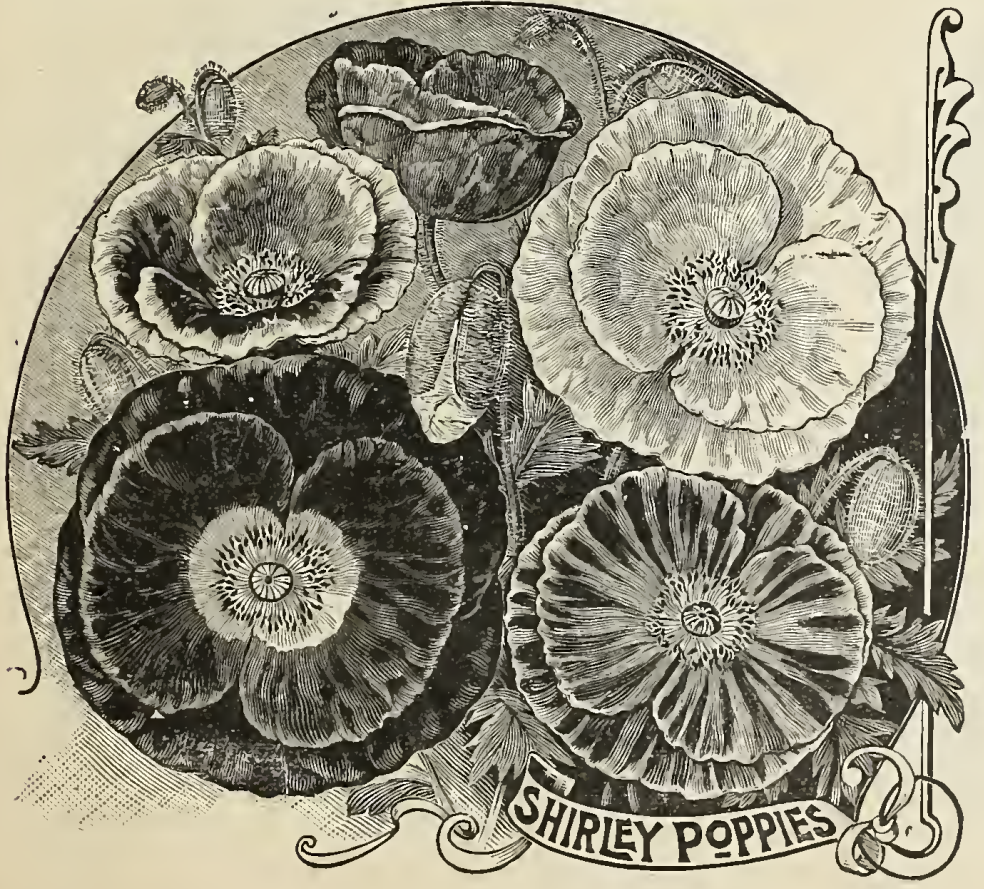

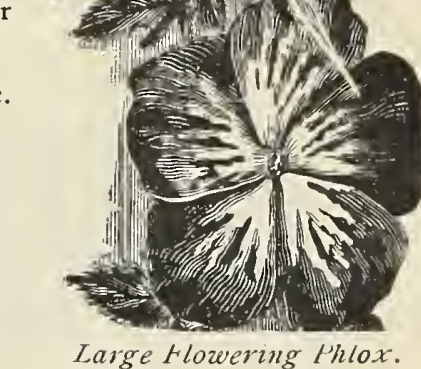

POPPIES.

Plants with large and brilliant colored flowers, growing freely in any common soil, producing a rich and effective display in mixed flower borders and shrubbery.

SINGLE ANNUAL POPPIES.

Tulip Poppy. A magnificent species from Armenia. The plants grow abo't fourteen inches high and produce from fifty to sixty large tulip-like flowers of dazzling scarlet. Price per pkt., Ioc.

Shirley Poppies. These are generally single or semi-double; the color extending from pure white through the most delicate shades of pale pink, rose and carmine. Price per pkt., Ioc.

Danebrog. Large bright scarlet, white cross in center. Price fer pkt., 5c. 


\section{POPPIES-Continued.}

Umbrosum. Richest vermilion, with a deep, shiny black spot on each petal. Price per pkt., 5c.

English Scarlet. The common field poppy of Great Britain, dazzling scarlet. Price per pkt., $5 \mathrm{c}$.

Flag of Truce. Satiny white flower, three to four inches across. Price per pkt., 5c.

Single Mixed. : Price per pkt.. 5c.
DOUBLE ANNUAL POPPIES.

Fairy Blush. Very double flowers, white, elegantly fringed and tipped with rose. Price per pkt., Ioc.

White Swan. Immense double flowers, beautifully fringed, and of purest white. Price per pkt, Ioc.

Mikado. The flowers are brilliant scarlet and white, with elegantly curved petals, like a Japanese chrysanthemum, the friuged edges being crimson scarlet. Price per pkt., loc.

Carnation Flowered. Splendid double fringed flowers, mixed colors. Price

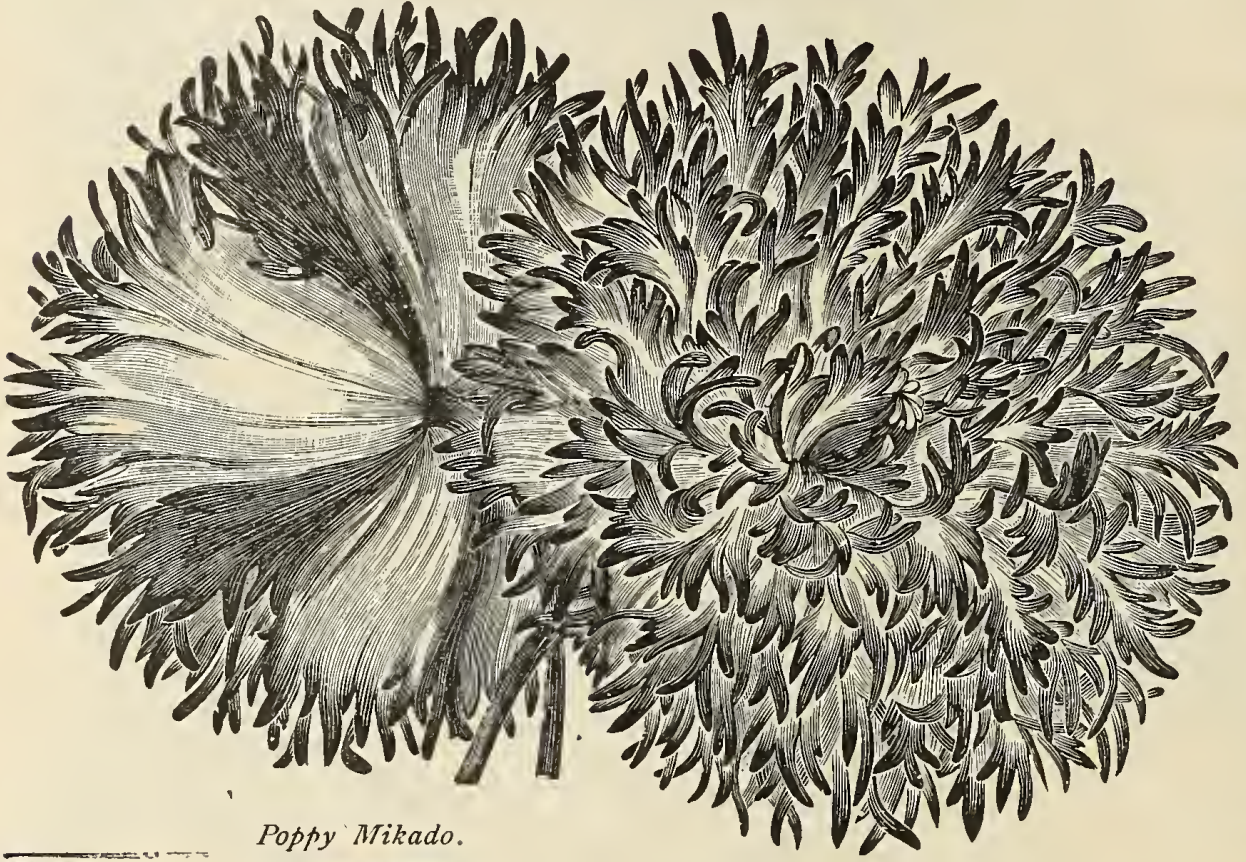

per $\mu \mathrm{kt}$., $5 \mathrm{c}$.

\section{HARDY PERENNALL POPPIES.:}

Bacteatum. Very large orange-scarlet flowers, averaging five inches in diameter. Perennia 1 variety. Price per pkt., 10c.

Nudicaule. (The Iceland Poppy.) Perfectly hardy, and profusion of flowers which are most useful for cutting. They have bright green, fern-like foliage, formed in tufts, from which issue tender stalks about twelve inches in height, surmounted by yellow, white or orangescarlet flowers. Price per pkt., Ioc. produce an endless

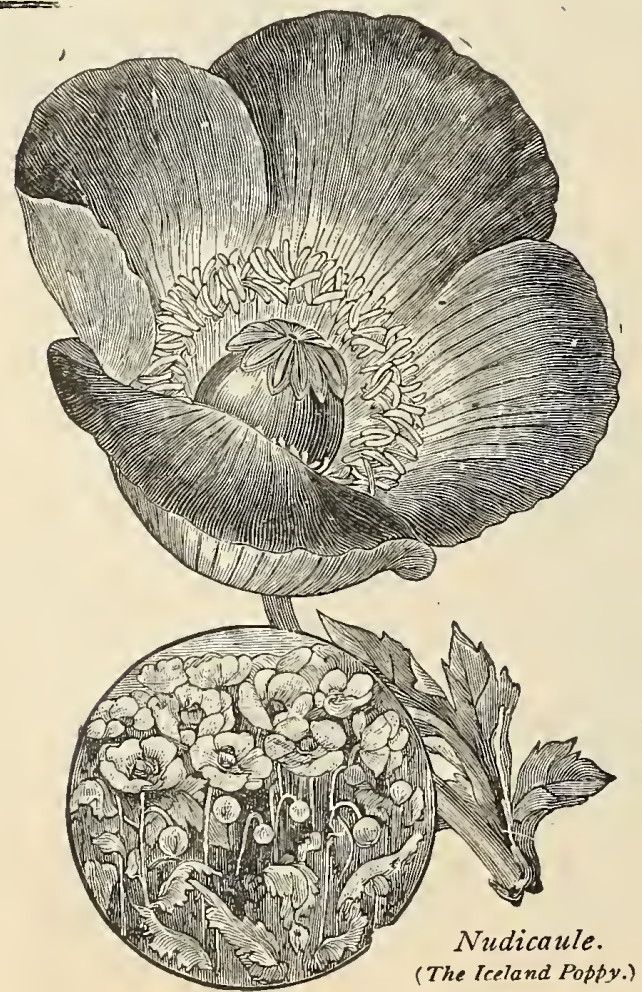

\section{PYRETHRUM.}

Handsome herbaceous plants of easy culture. P. Aureum is the well known Golden Feather. so much

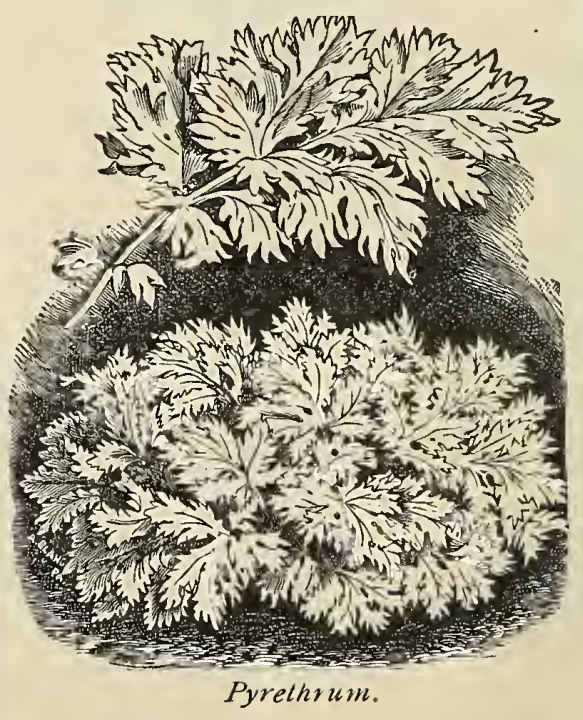
used for carpet bedding, eriging, etc. From the flowers of $P$. Roseum is obtained the Persian insect puwder. P. Hybridum and varieties are a mong the handsomest of hardy flowering herbaceous plants.

A u re u m. (Golden

Fealher.)

Bright yellow foliage. Price per pkt., 5c.

Roseum. (Persian Insect Powder Plant.) Flowers bright rose; one and one-half feet. Per pkt., Ioc, 


\section{PRIMULA.}

Chinese Primrose.

This is a beautiful flowering plant for winter or spring decorations in the home or conservatory. It is usually advised to sow Primula seeds in July and August, but in our hot, dry climate it is very difficult for them to germinate at that season. I have found that the best time to sow is in February, March or April. Then sown, the seeds germinate freely, aud fine plants can be had for winter flowering.

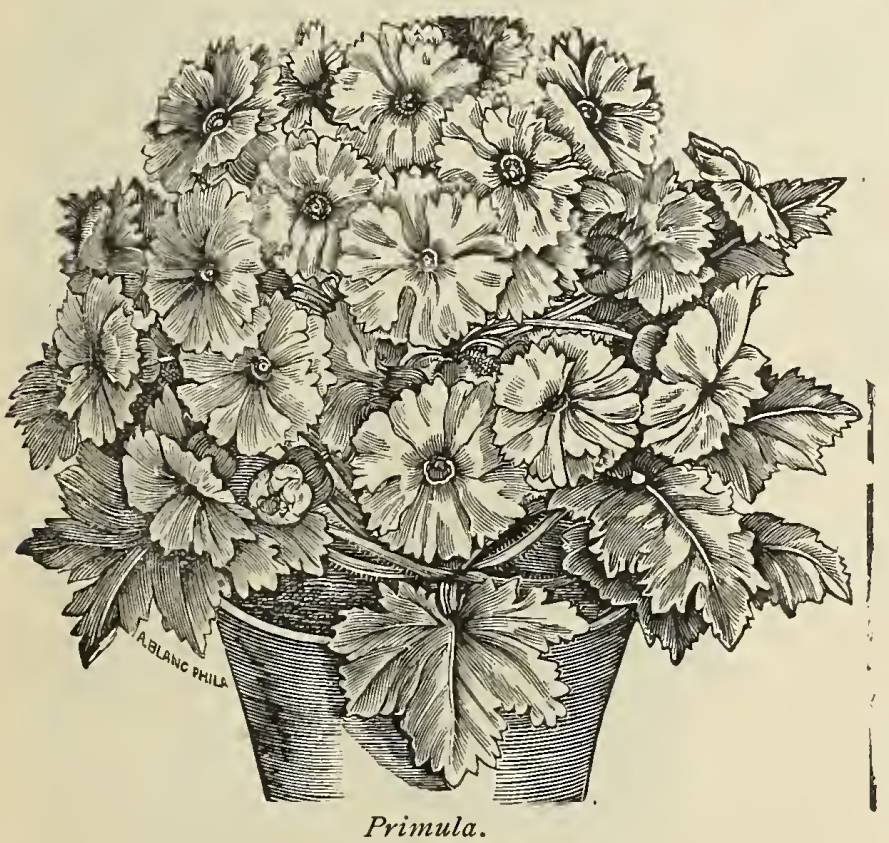

RHODANTHE.

Maculata, Mixed. Half-hardy annual. Valuable forgarden or pot culture, as they come into flower early and continue for a long time. An everlasting. Flowers of various colors; white, pink, crimson, etc. Price per pkt., 5 c.

\section{RIGINUS.}

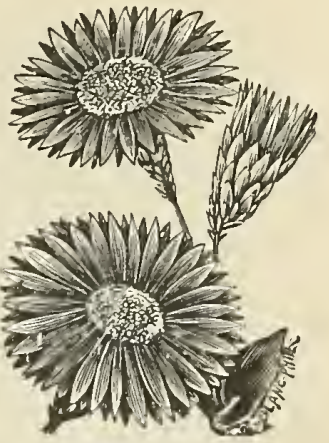

Rhodanthe.

Large, luxuriant, rapid-growing foliage annual, with palm.l1ke leaves; much used for sub-tropical effects on the lawn, or for centers of beds of foliage plants.

Zanzibarensis. The different varieties included in our mixture bave light and dark green leares and some of coppery bronze changing to dark green, with reddish ribs; six to tell feet. The seeds are quite distinct in color and beautifully marked. Price oz., 2oc.; per pkt., 5c.

Cambogiensis. Leaves of a bronzy red maroon color, with large, red veius; the main stem or trunk, ebony black. Price per pkt., Ioc.

Borboniensis. Fifteen feet; grows very :- large and rank; foliage green. Price per E.pkt., 5c.

Gibsonii. Six feet; red foliage and stems. Price per pkt., 5c.

\section{SINGLE VARIETIES.}

Single White Fringed. Price per pkt, $25 \mathrm{c}$.

Single Red Fringed. Price per pkt., $25 \mathrm{c}$.

Superb Mixed. This strain of English Primula is universally admired, and contains the finest varieties and colors. Price per pkt., 25c.

Fine Mixed Colors. Price per pkt., I5c.

\section{DOUBLE GHINESE PRIMROSE.}

White. Price per pkt., 5oc.

Mixed. Price per pkt., 5oc.

\section{HARDY PRIMROSES.}

These are among the lest of the early spring bloomiug plants. With a slight protection they will stand the wiuter, but do better if protected by a cold frame.

Primula Japonica. (Japanese Primrose.) Bright and showy flowers, borne in whorls on stems six to nine inches long; mixed colors. Price per pkt., roc.
Finest Mixed. Price per oz., I5c.; per pkt., 5c.

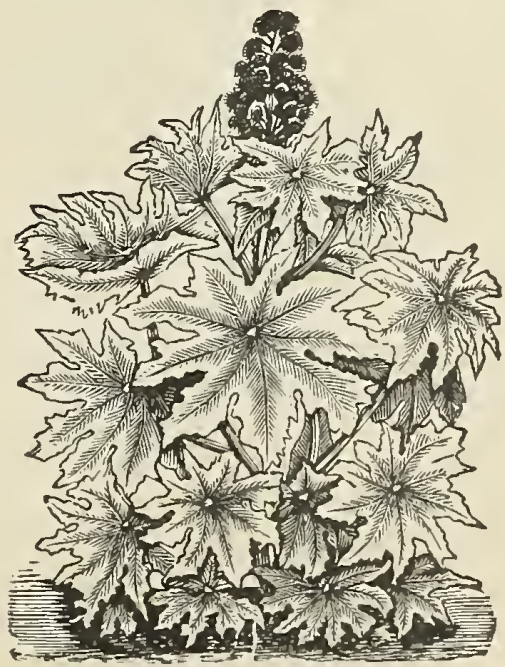

Ricinus. 


\section{RUDBECKIA.}

Cone Flowers.

These robust-growing plants are fine free flowering annuals. They are of very easy culture and produce showy flowers during summer and autumn.

Bicolor. An annual variety; bright yellow, with black-purple center. Price per pkt., Ioc.

Newmanii. Perennial ; grows two feet; 1arge, goldenyellow flowers with velvety maroon center cone. Price per pkt., Ioc.

\section{SALPIGLOSSIS.}

One of the most beautiful of flowering annuals, forming strong, bushy plants about eighteen inches high, and bearing throughout the season large flowers

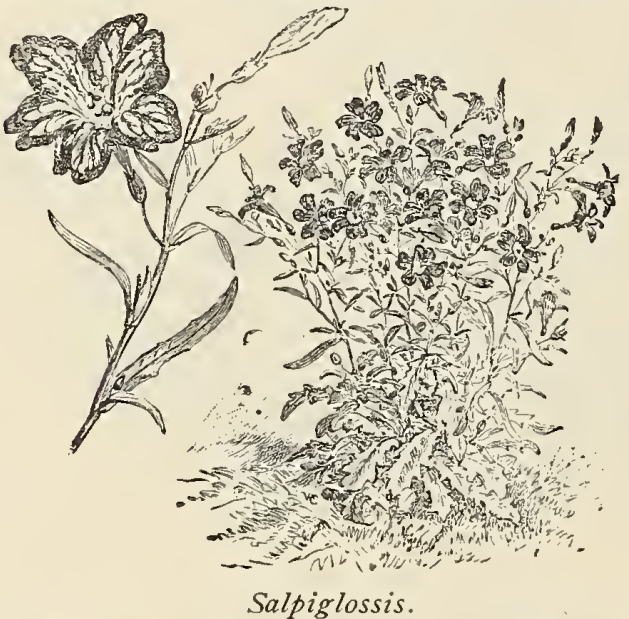

of many beautiful colors, all exquisitely veined and laced.

Large Flowering Mixed. Price per pkt., $5 \mathrm{c}$.
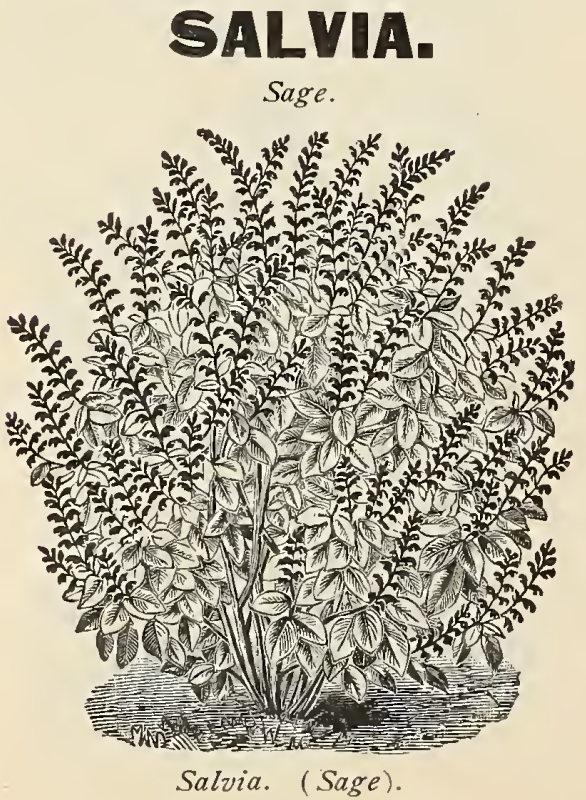

Splendid ornamental plants for outdoor decorations, their beautiful spikes of brilliant scarlet and blue flowers being produced in great profusion from July until October. Half-hardy annual.

Splendens. Scarlet, free bloomer. Price per pkt., Ioc.; per oz., $\$ 1.50$.

Splendens "Bonfire." (Nana Compacta Erecta.) Growing in a compact bush about two feet high. Its erect spikes of flowers of brilliant scarlet stand clear above the dark green foliage and completely cover the plant. Price per pkt., I5c.

Patens. Spleudid deep blue. Price per pkt., $20 c$.

\section{Sanvitalía.}

Pretty, dwarf - growing, free-flowering plants, suitable for small beds, rock work or edgings, continuing in bloom during the sunimer and a $u \mathrm{tumn}$ months. Hardy annual.

Procumbens. Double, golden yellow. Price per pkt., 5c.

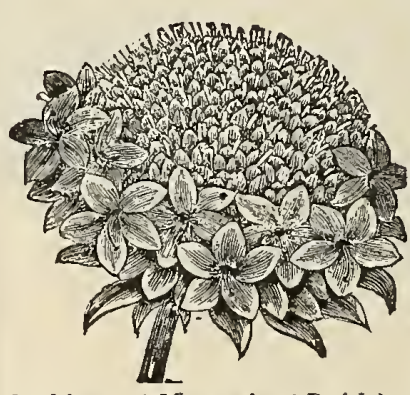

Scabiosa. (MourningiBride).

Mixed Dwarf Double. One foot. Price per pkt., $5 \mathrm{c}$.

Tall, Large Flowering, Dou= ble. Mixed. Price per pkt., 5 c.

\section{Schizanthus \\ The Butterfly Flower.}

A class of plants combining elegance of growth with a rich profusion of curiously striped and blotched flowers. Halfhardy annual.

Best Mixed Varieties. Price per pkt., $5 \mathrm{c}$

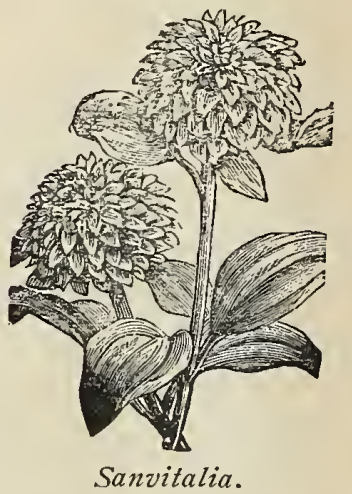

Mourning Bride.

A beautiful border plant, producing a profusion of flowers in great variety of colors; excel. lent for cutting for table bouquets, etc. The flowers are quite doubleand globular, varying in all shades of white, carmine, maroon, lilac, etc. Hardy annual.

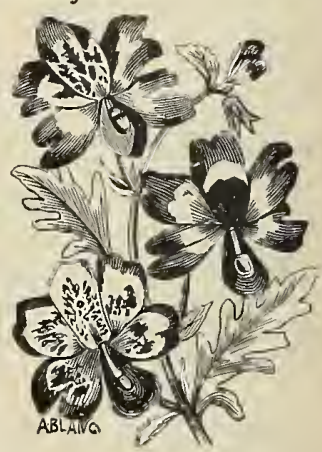

Schizanthus.
Scabiosa.

\section{SMILAX.}

\section{Myrsiphyllum.}

There is no climbing plant in cultivation that surpasses this in the graceful beauty of its foliage. In cut flowers it is considered indispensable by florists.

Smilax. Price per oz, 5oc.; per pkt., Ioc. 


\section{STOCKS.}

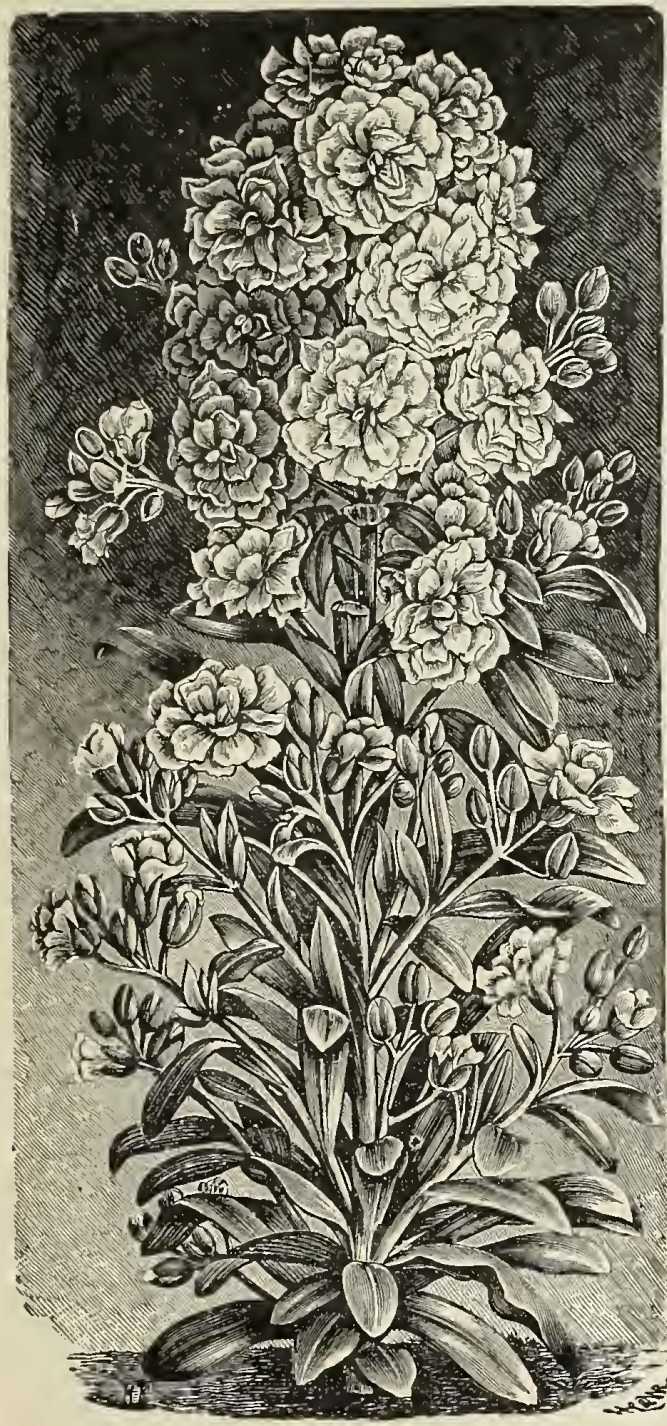

Stock-Princess Alice. :

\section{GERMAN TEN-WEEKS.}

The Ten-Weeks' Stock ("Stock Gilly," or "Gillyflower," as they are sometimes called) are especially recomnended on account of their long continuance in bloom and vigorous habit. Very desirable for pot culture or out-door blossoming. Flowers very double. Half-hardy annual.

German Ten=Weeks. Fine mixed. Price per pkt, $5 \mathrm{c}$. Large Flowering Choice mixed. Price per pkt., Ioc. Pure White. Price per pkt., IOc.

Scarlet Victoria. Brilliant red. Price per pkt., Ioc. Princess Alice. (Cut and Come Again.) A fine perpetual blooming stock, growing about two feet high. If sown early it commences blooming in June, and continues until destroyed by frost. It throws out numerous side branches bearing clusters of very double, pure white, fragrant blossoms. Price per pkt., roc.

Large Flowered Dwarf Pyramidal. Very finest mixed. Price per pkt., Ioc.
Intermediate or Autumnal Flowering. Very beautiful choice double flowers; mixed. Two feet. Price per pkt., Ioc.

\section{SOLANUM.}

An ornamental and interesting genus of fruitbearing plants; singularly gro. tesque in fruit and foliage.

\section{Capsicastrum.}

(lerusalem Cherry). Covered with scarlet fruit during winter. $I / 2 \mathrm{ft}$. Price per pkt., 5c.

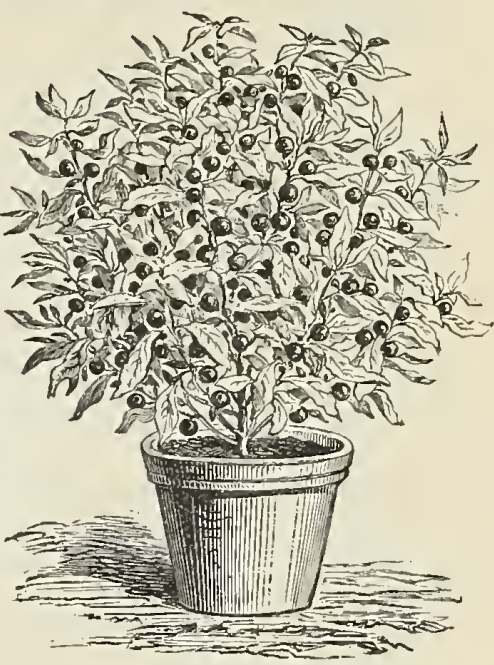

Solanum.

\section{SWEET WILLIAM. Dianthus Barbatus.}

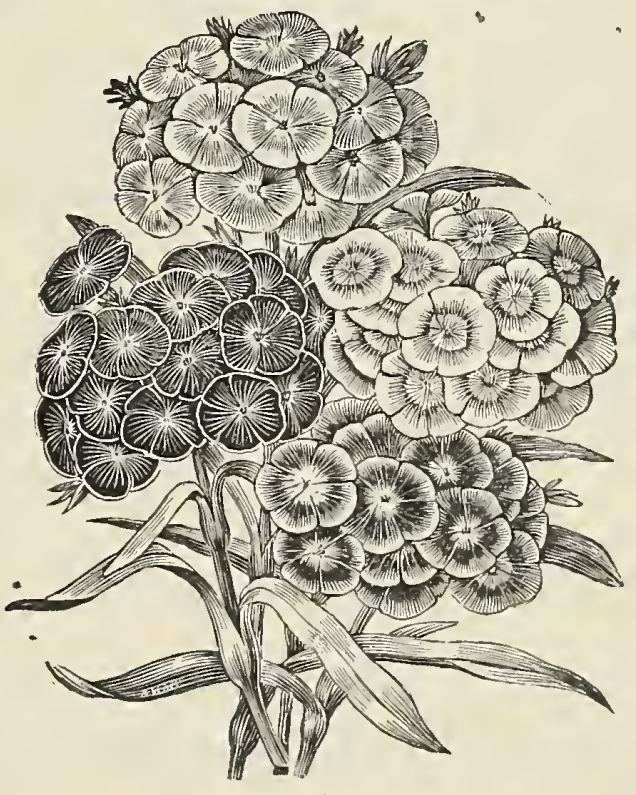

Sweet William

A very beautiful class of plants, of extreme neatness and diversity of color. For display in the garden or borders, the Sweet William is indispensable; grown in clumps, twelve to eighteen inches high. Hardy perennial

Fine Mixed. Price per pkt., 5c.

Double Flowering. Finest mixed. Price per pkt., 


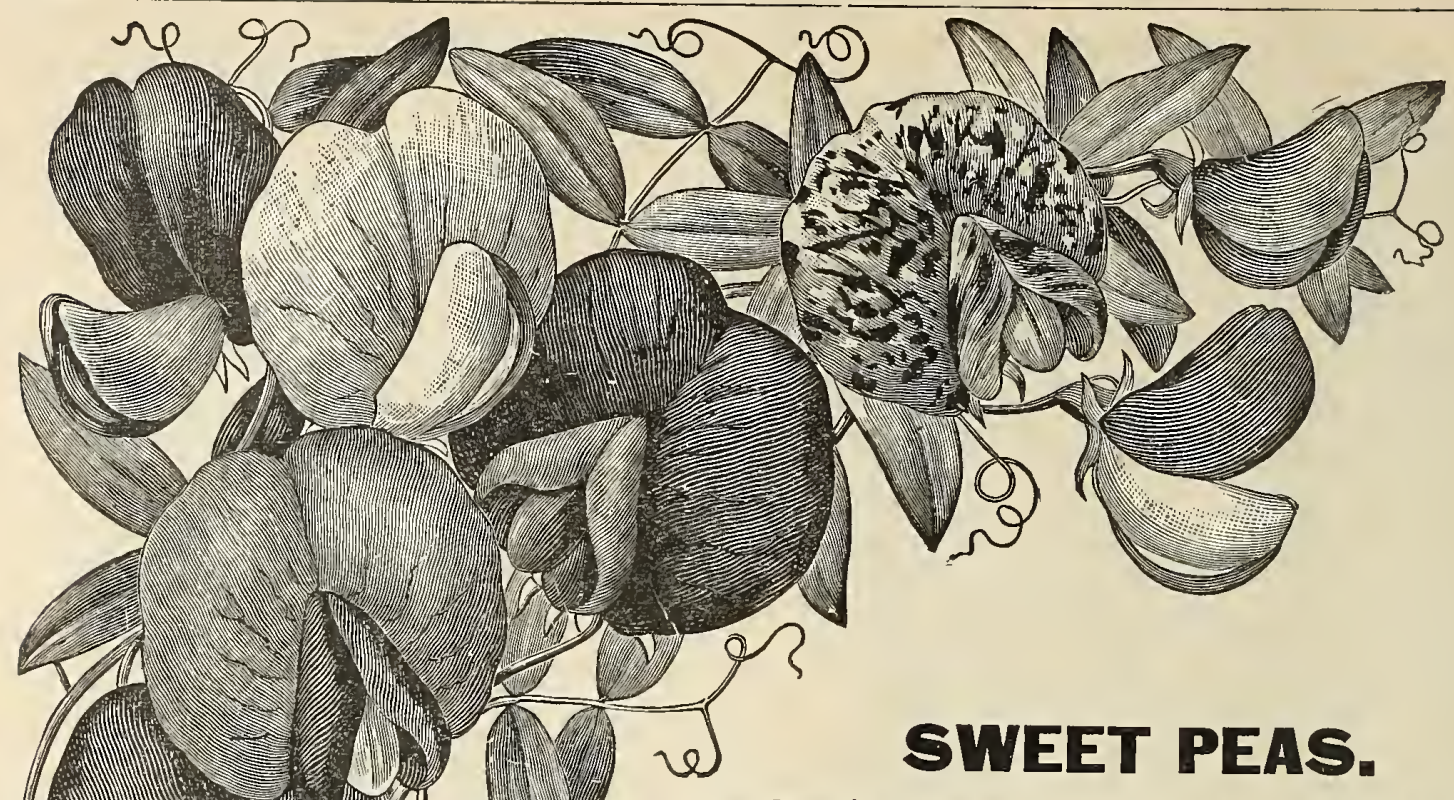

Free-flowering climber, continuing in bloom all the summer; valuable in trailing or trellis work, covering rough fences, etc. Seeds should be sown as early in the spring as is practicable to work the ground, and covered deeply, four to six inches.

Apple Blossom. A handsome variety, extra large flowers, standard apple blossom, rose pink, wings exquisite soft blush. Price per pkt., 5c.; per oz., Ioc.; per 1b., 4oc.

Blanche Burpee. Largest, pure white. Price per pkt., 5c.; per oz., Ioc.; per 1b., 6oc.

Blanche Ferry. Standard is a bright pink and the wings nearly white. Price per pkt., 5c.; per oz., Ioc.; per 1b., 5oc.

Black Knight. Very large, and darkest maroon. Price per pkt., 5c.; per 07., Ioc.; per lb., 6oc.

Katherine Tracy. Soft, rosy pink. Price per pkt., 5 c.; per oz., roc.; per 1b., 5oc.

Lottie Eckford. Very pale mauve standards; wings white, with soft mauve. Price per pkt., 5c.; per oz., Ioc.; per 1b., 5oc.

Mars. Bright, fiery crimson. Price per pkt., 5c.; per oz., Ioc.; per 1b., 6oc.

Mrs. Eckford. Delicate primrose-yellow. Price per pkt., 5c.; per oz,, Ioc.; per lb., 5oc.

Navy Blue. Bright blue, finest of its color. Price per pkt, 5c.; per oz.. Ioc.; per lb., \$1.00.

Sweet Peas.

New Countess. Delicate lavender. Price per pkt., 5c.; fer oz., Ioc ; per $1 \mathrm{~h}, 75 \mathrm{c}$

Eckford's Hybrids. Finest mixed; a carefully proportioned mixture of the best of the preceding varieties, which cannot fail to give flowers of the hest form and a wide range of color. Price per pkt., 5c.: per oz., Ioc.; per lb., 4oc.

Choice Mixed. This mixture contains some of the newer and rarer kinds, and while not quite equal to the ahove, yet can be depended upon to make a fine display and give satisfaction. Price per pkt., 5c.; per oz., Ioc.; per 1b., 30c.

\section{THUNBERGIA.}

Sometimes called "Black-eyed Susan." Extremely ornamental, free-blooming climbers of rapid growth, handsome foliage and much. admired flowers; good for greenhouse culture, or in warm situations out-doors. Half-hardy annuals.

Fine Mixed. Price per pkt., $5 \mathrm{c}$.

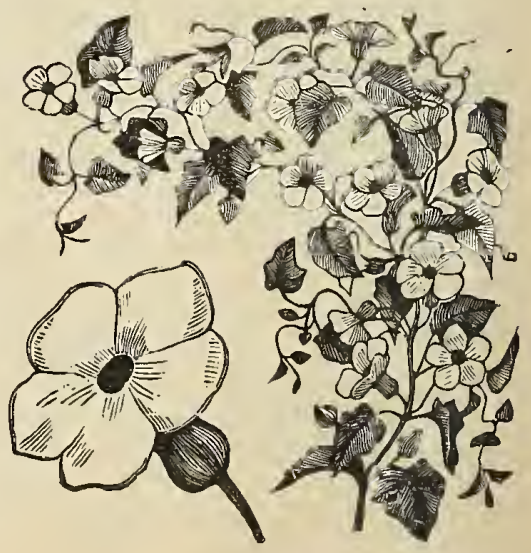

Thunbergia 


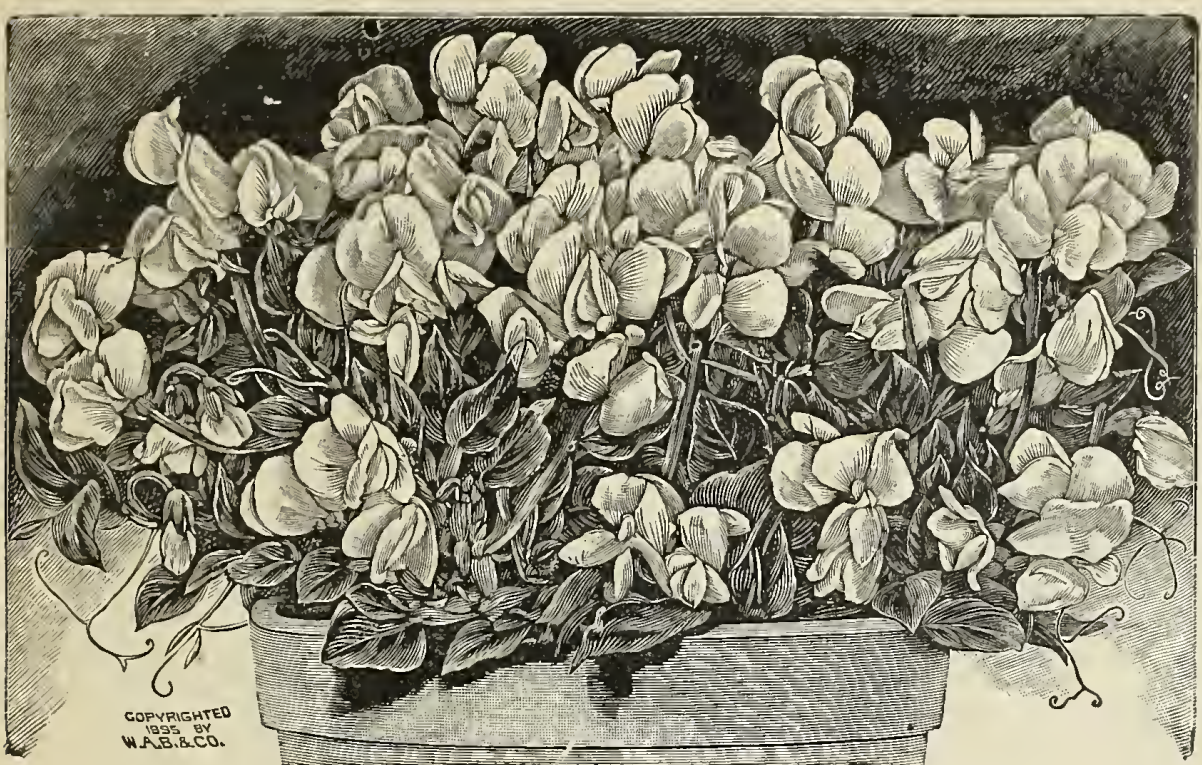

Cupid, Dwarf or Bedding Sweet Peas.

\section{Gupid, \\ Dwarf or Bedding Sweet Peas.}

Alice Eckford. Rich, creamy white, blended with soft flesh pink. Price per pkt., roc.

Beauty. Rosy pink, shading to white at the edges. Price per pkt., Ioc.

Primrose. Creamy yellow. Price per pkt., roc.

Pink. Rosy pink standard, white wings. Price per pkt, Ioc.

White. Pure white. Price per pkt., Ioc.

\section{VERBENA.}

Well-known and universally admired plants; invaluable for summer decoration, blooming freely the first year from seed. Halfhardy perennial.

Fine Mixed. Price per pkt., 5 c.

Mammoth Choice. Mixed. A grand collection of magnificent varieties. Price per pkt., Ioc.

Mammoth White. Price per pkt., roc.

Mammoth Scarlet. Price per pkt., roc.

\section{VINCA.}

Free-flowering, compact, greenhouse evergreen shrubs, with shin- ing green foliage and handsome circular flowers. If sown early in spring will flower the same season, and will be very useful for bedding or pot culture.

Rosea. Rose. Price per pkt., 5c.

Rosea Alba. White, with crimson eye. Price per pkt., 5c.

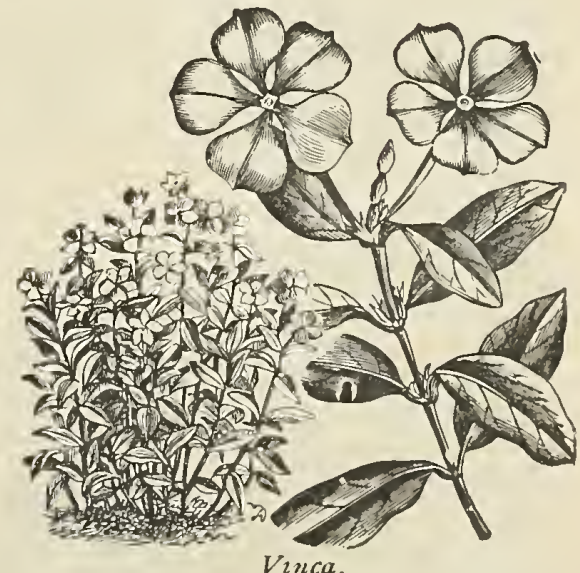




\section{WALL-FLOWER.}

A well-known plant of the Gillyflower family, producing its rich orange or chocolate flowers in the spring

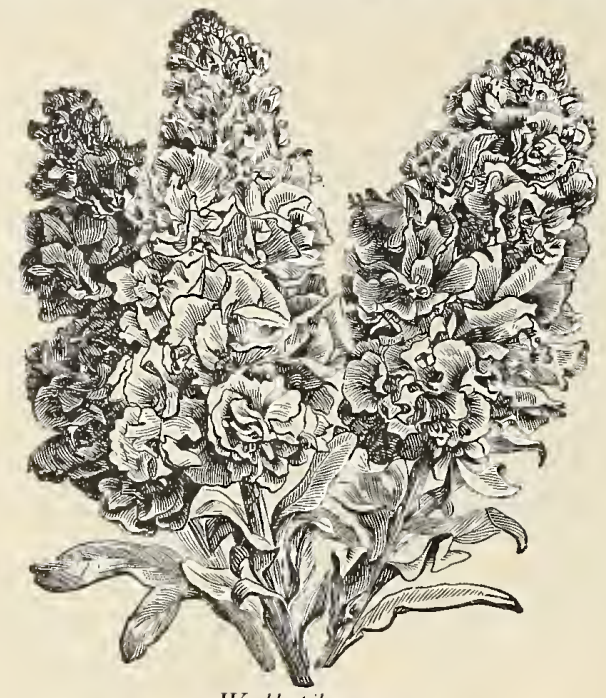

Wall-Flower. if protected in the house during the winter. Halfhardy perennial.

Single. Finest nixed. Price per pkt, 5c.

Double. Finest mixed. Price per pkt., roc.

\section{ZINNIA.}

Annual of great beauty and brilliancy; of branching habit aud superb colors; continues in bloom a long time ; very effective in beds, groups or mixed borders. Half-hardy annual.

Large Flowering, Double White. Price per pkt., $5 \mathrm{c}$. Large Flowering, Double Scarlet. Price per pkt,. 5c.

Zebra. A very pretty strain of striped flowers. As the colors vary on each plant, they present a curious as well as pretty appearance. Price per pkt., roc.

Double Lilliput. Close, bushy plauts bearing small double pompou-shaped flowers of brightest colors. Price per pkt., Ioc.

Extra Double Mixed. Price per pkt., Ioc.
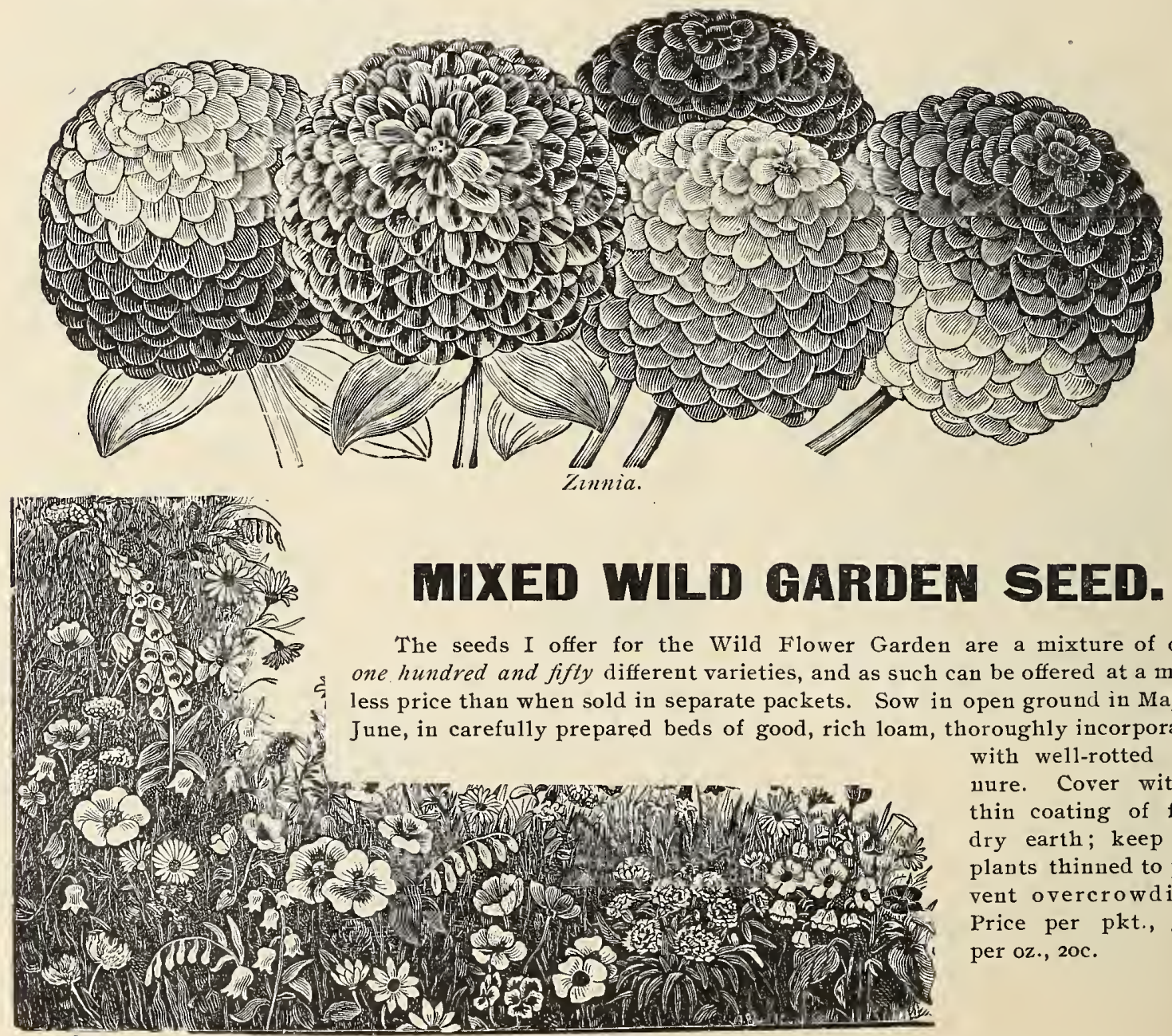


\section{MISCELLANEOUS BULBS.}

\section{NEW LARGE - FLOWERING FRENGH GANNAS.}

Unquestionably the finest plants of our entire list for summer blooming and lawn decoration. They produce the tropical luxuriance of foliage of the common kinds, to which is added the gorgeousness of their flaming panicles of bloom, which are borne in immense heads at the terminus of every shoot, the colors ranging througli all the shades of orange, scarlet and crim-
Egandale. Foliage dark bronzy niaroon, interlaced with green. A perfect dark-leaved variety. Flower heads of compact form ; color, bright cherry. Four feet. Price each, Ioc.; per doz., \$1.00.

Florence Vaughan. Bright, rich golden yellow, spotted with red; flowers of the largest size; foliage rich green Three feet. Price each, Ioc.; per doz.,\$r.00. Francoise Crozy. The color is a shade of apricot,

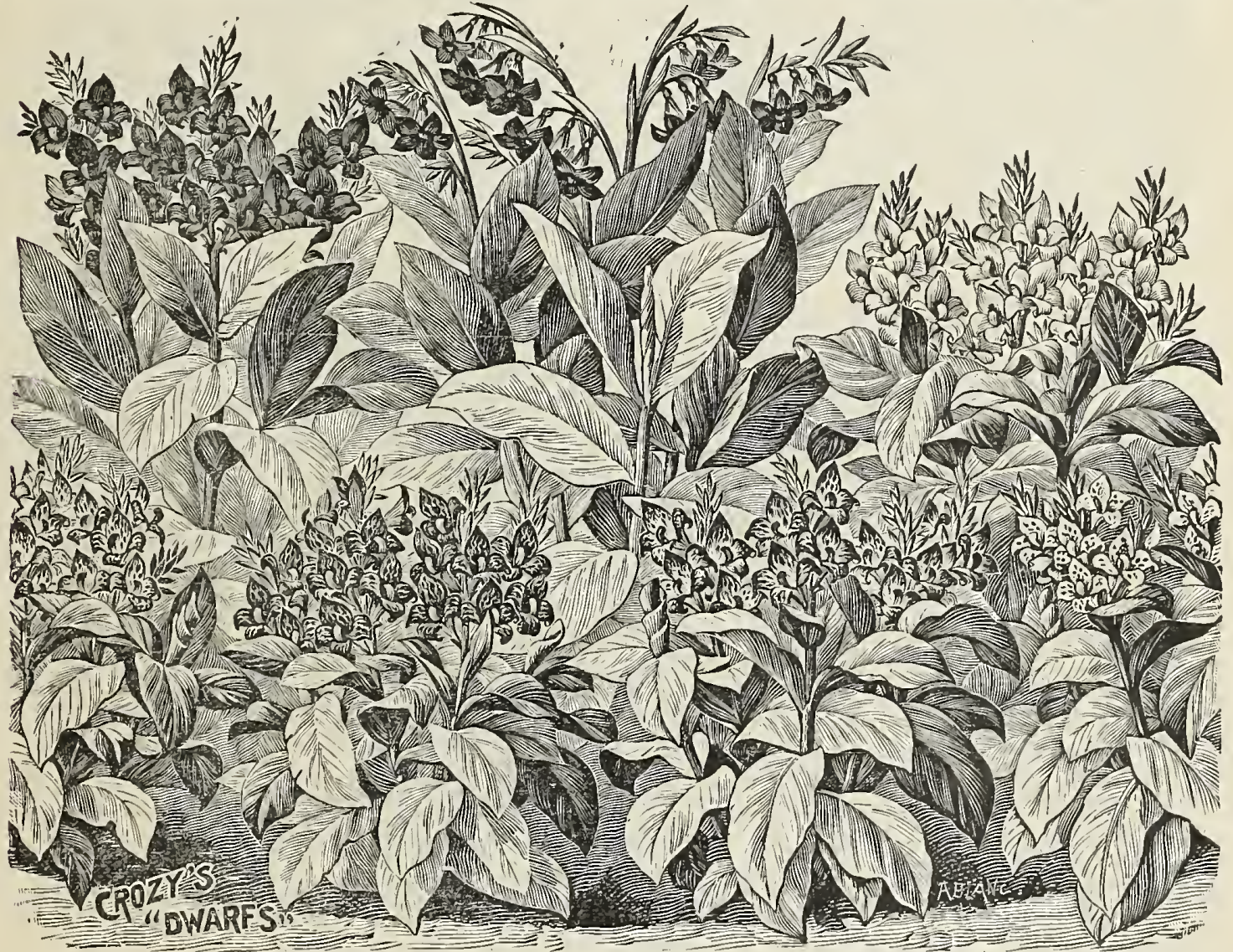

French Cannas.

son. Mauy are striped, spotted, veined, or beautifully margined. The main requisite for culture is rich soil, deeply dug and heavily manured.

Alphonse Bouvier. The color is rich, brilliant crimson; foliage deep green. Five to six feet. Price each, Ioc.; per doz., \$1.0o.

Burbank. Very large canary-yellow flowers, flecked with carmine spots in the throat. Foliage green and vigorous. Price each, Ioc.; per doz., \$1.oo.

Charles Henderson. A fine crimson, very popular. Its habit of growth is compact and uniform, rarely exceeding three and one-half feet in height. Price each, Ioc.; per doz., $\$ 1.00$. bordered with bright yellow. Price each, Ioc.; per doz., \$1.oo.

J. D. Cabos. Strong grower, leaves green, strongly shaded with purple, flowers large and round, color rich apricot with deeper shadings. Price each, Ioc.; per doz, \$1.oo.

Madame Crozy. The flowers are of the largest size, scarlet, bordered with golden yellow. The plant is dwarf in habit; foliage light green. Price each, Ioc.; per doz., \$r.oo.

Paul Marquant. Large flowers in bold, shapely trusses; salmon rose. Price each, [oc.; per doz., \$1.oo. Queen Charlotte. Resembling the Madame Crozy, but having a much wider band of yellow around each petal: Price each, I5c.; per doz., \$1.50. 


\section{TUBEROUS-ROOTED BEGONIAS.}

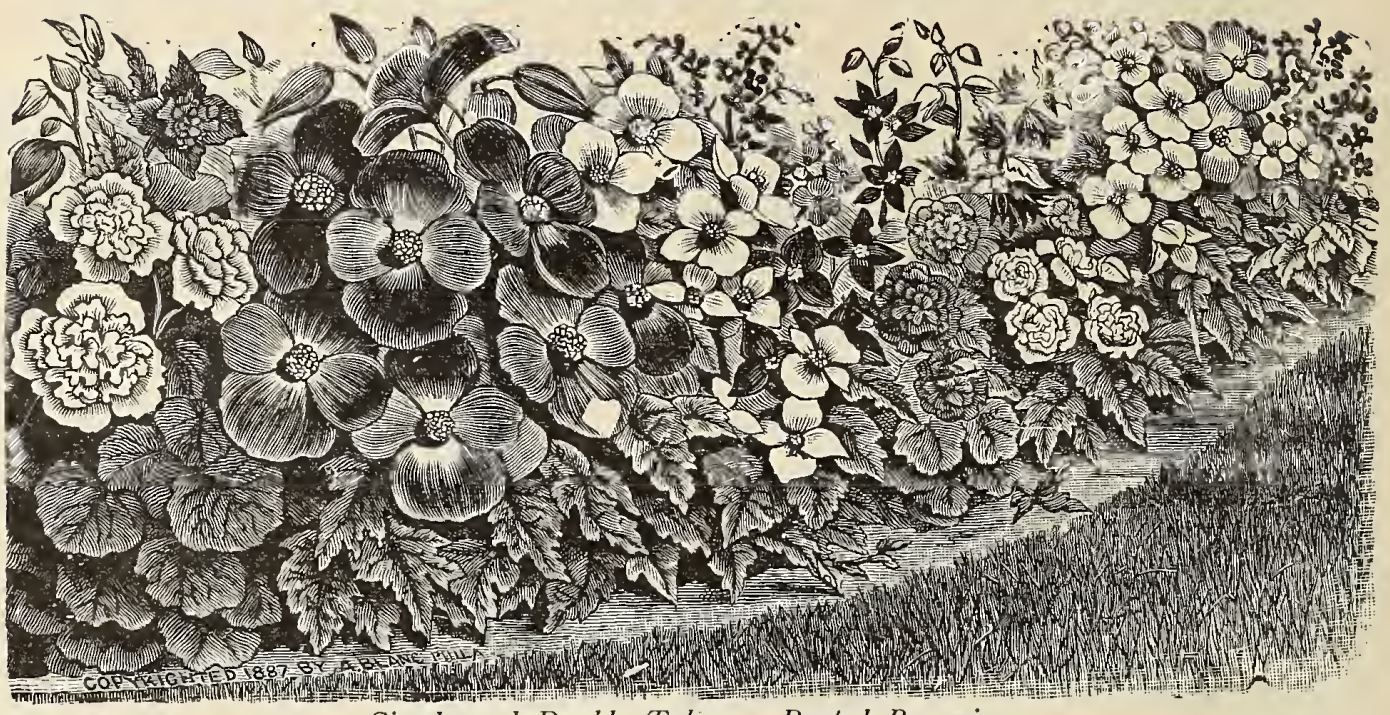

Single and Double Tuberous-Rooted Begonias.

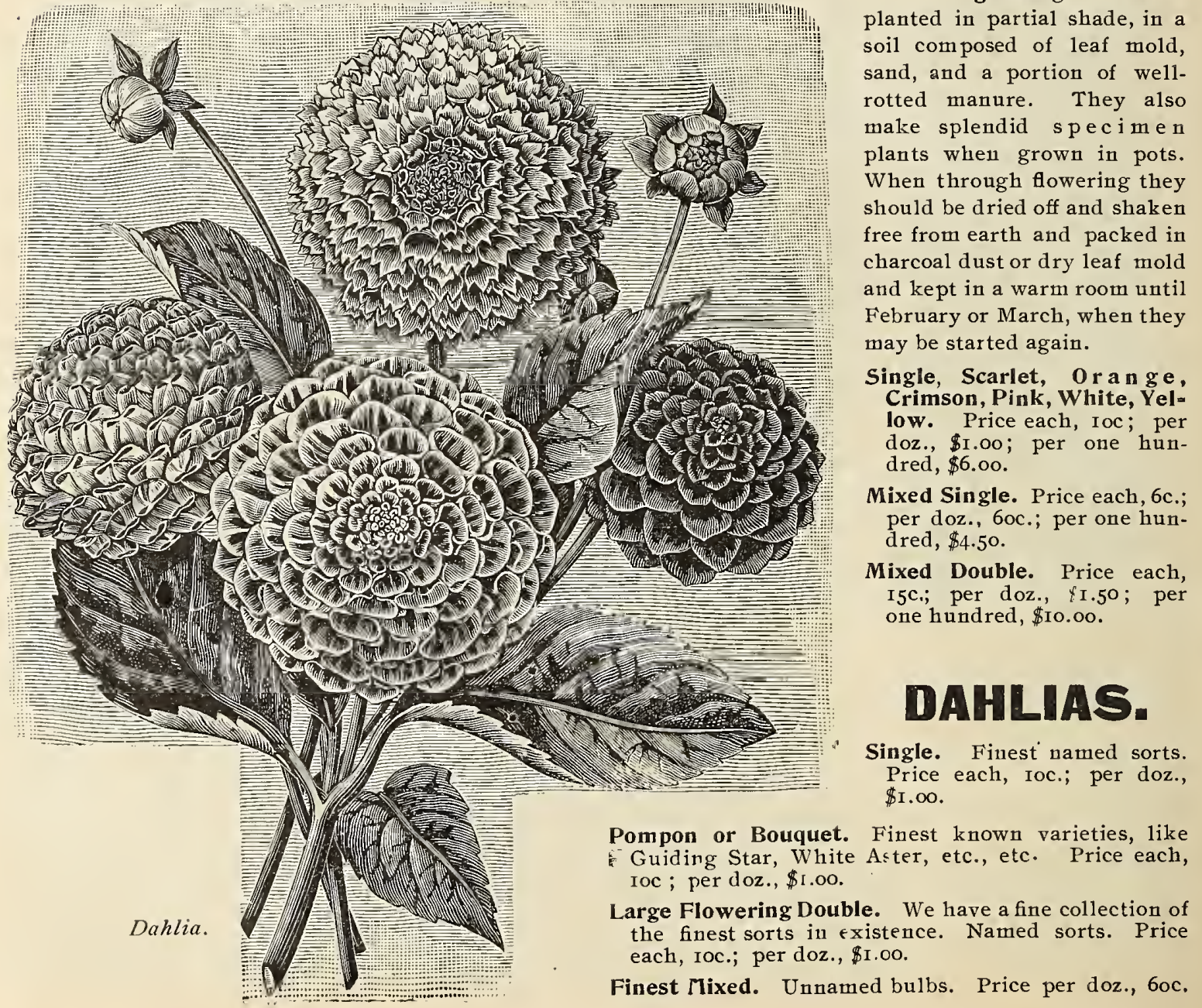

The begonias grow best if planted in partial shade, in a soil composed of leaf mold, sand, and a portion of wellrotted manure. They also make splendid specimen plants when grown in pots. When through flowering they should be dried off and shaken free from earth and packed in February or March, when they may be started again

low. Price each, Ioc; per doz., \$1.0o; per one hunMixed Single. Price each, 6c; per doz., 6oc.; per one hundred, $\$ 4.50$ I5c; per doz., fI.5O; per one hundred, \$10.00.

\section{DAHLIAS.}

gie. Finest named sorts Price each, Ioc.; per doz., $\$ 1.00$.

Pompon or Bouquet. Finest known varieties, like Guiding Star, White Aster, etc., etc. Price each, IOc ; per doz., \$1.00 the flowering Double. We have a fine collection of each, Ioc.; per doz., \$1.00.

Finest Mixed. Unnamed bulbs. Price per doz., 6oc. 


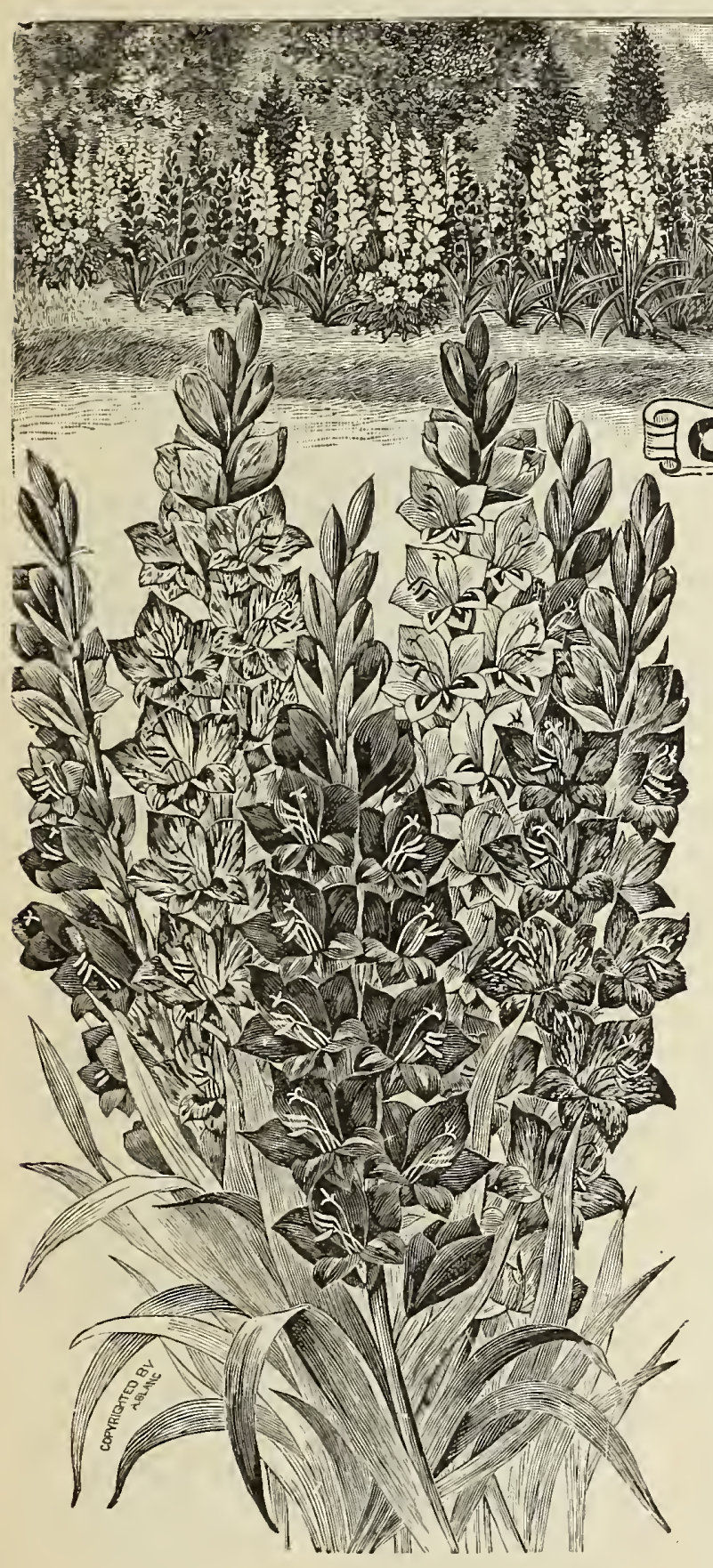

The most:brilliant and showy of all the summerflowering bulbs. Their immense spikes of gorgeous bloom comprise in color all the shades from white to the deepest scarlet, purple and yellow, with blotchings and markings of charmingly contrasted shades. They will grow in any good garden soil and bloom with the most ordinary care. The bulbs should be planted at intervals, in A pril and May, to secure a succession of bloom. Take up in the fall and store in a dry cellar or other cool place, well protected from frost.

\section{GLADIOLUS BULBS.}

(Choice Mixtures)

All Colors Mixed. Price each, 2c.; per doz.; 2oc.; per one hundred, $\$ 1.50$.

My "Choice Mixture." Price each, 3c.; per doz., 35c.; per one hundred, $\$ 2.00$.

Shades of Whi, e and Light. Price each, 3 c.; perdoz., $35 \mathrm{c}$.; per one hundred, $\$ 2.50$.

Shades of Yellow. Price each, 3c.; per doz., 35c.; per one hundred, $\$ 2.50$.

Shades of Pink and Variegated. Price each, $3 \mathrm{c}$; per doz., 35c.; per one hundred, $\$ 2.50$.

Shades of Red. Price each, 3c.; per doz., 25c.; per one hundred, $\$$ I.75.

\section{Caladium Esculentum.}

One of the largest of ornamental foliage plants, grows in any garden soil, and when full size stands four or five feet high, with immense leaves, often measuring four feet in length, by two and one-half feet in breadth.

Extra Large. Price each, 25c.; per doz., \$2.50.

First Size Bulbs. Price each, I5c.; per doz., \$1.50.

Second Size Bulbs. Price each, roc.; per doz., \$1.oo.

Third Size Bulbs, Price each, 5c.; per doz., 5oc.

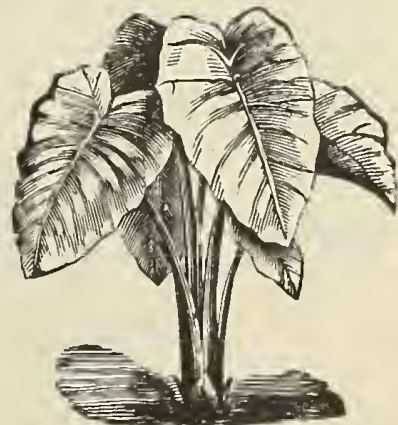

Caladium Esculentum. 


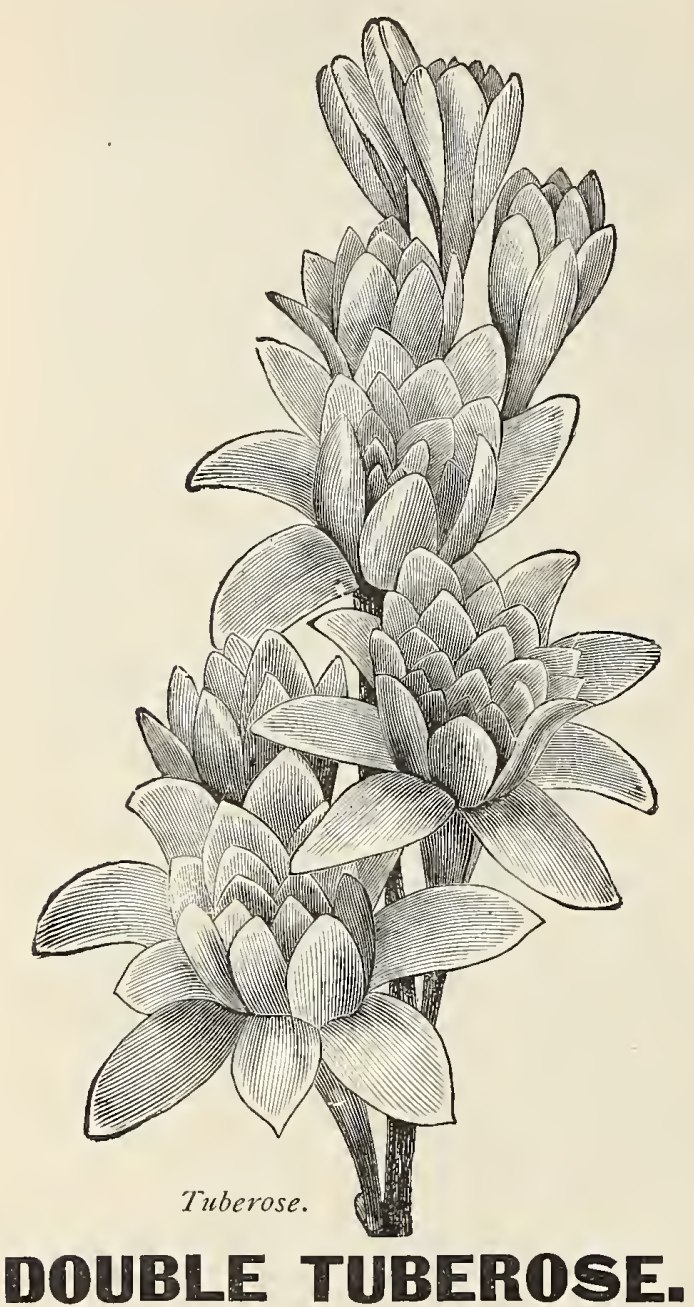

The tuberose, being a native of a tropical climate, requires the extreme heat of summer, and will not bloom till late unless started in the forcing-house or hot-bed in February or March. They may be transferred to open ground after the soil has become warm and settled summer weather prevails. The bulbs are extremely sensitive; a slight freezing destroys the crown or heart.

\section{EXCELSIOR DWARF PEARL.}

First Size. Price each, 3c.; per doz., 25c.; per one hundred, $\$ \mathrm{r} .50$.

Second Size. Price each, 2c.; per doz., r5c.; per one hundred, \$r.oo.

Third Size. Price each, Ic.; per doz., Ioc.; per one hundred, $75 \mathrm{c}$.

\section{HARDY AND HERBACEOUS PLANTS GINNAMON VINE.}

Beautiful summer climber; glossy foliage and fragrant flowers; stem dies down in wtnter, but the root is hardy. Large selected roots. Price each, 5c.; per doz., 5oc.

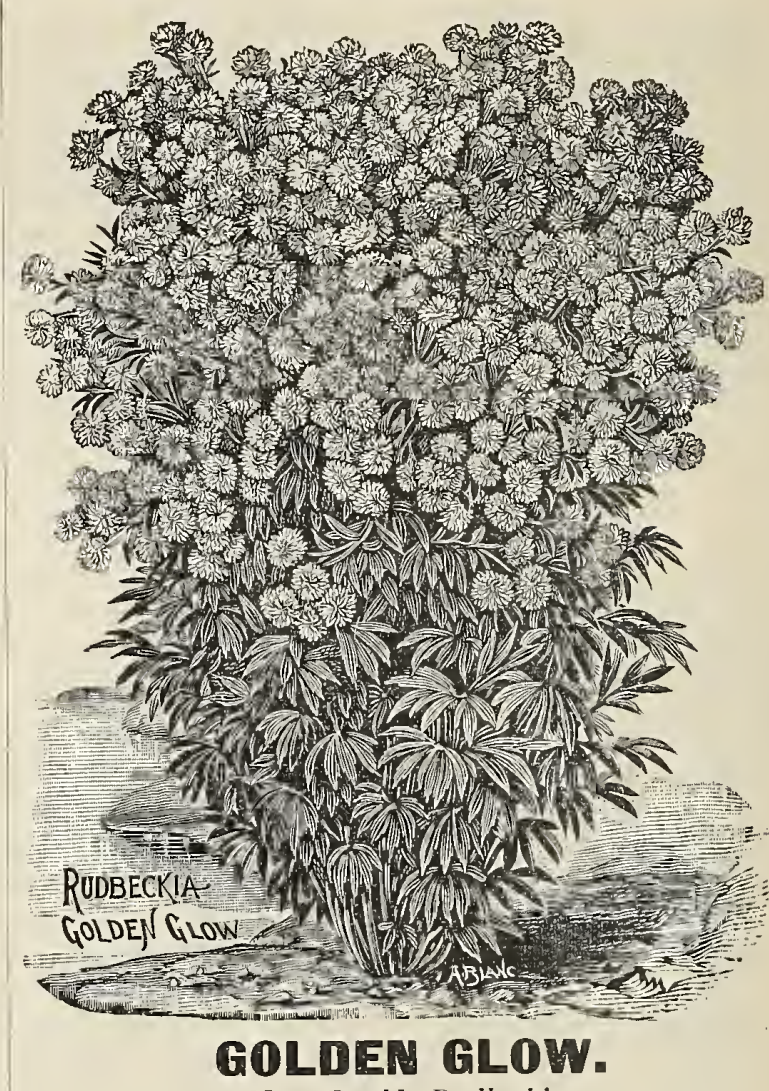

New Double Rudbeckia.

A hardy perennial plant growing four to eiglit feet high, branching freely, and blooming profusely, on long, graceful stems; exquisite double blossoms of the brightest golden color. Price each, 25c.; per doz., $\$ 2.5$.

\section{DIELYTRA SPECTABILIS.}

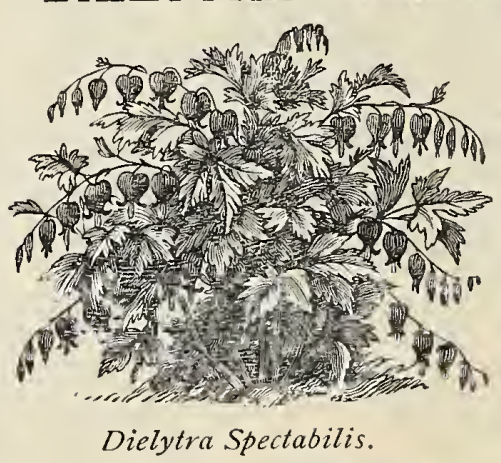

\section{FUNKIA. \\ Day Lily.}

Bleeding Heart.

One of our most ornamental spring plants, with handsome pæony-like foliage and $10 \mathrm{ng}$, drooping raceemes of bright pink and white heart-shaped flowers.

Dielytra Spectabilis. Price each, 20c.; per doz., $\$ 2.00$.

The roots should be set out in the autumn to become well established, and they will bloom the following spring. They need not be disturbed for many years.

Alba. Pure white, fragrant flowers, green foliage. Price each, 25c.; per doz., $\$ 2.50$.

Funkia Variegata. Foliagevery handsome, green and white ; flowers lilac. Price each, 25c.; per doz., $\$ 2.50$. 


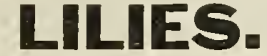

Auratum, the Golden Banded Lily of Japan. Flowers a foot across, pure white, spotted crinson, with a golden baud through the center of each petal; very fragrant; the king of lilies. Price each, I5c.; per doz., \$I.5o.

Tigridias. Tiger lily, orange-spotted. Price each, Ioc.; per doz., $\$ 1.00$.

Roseum or Rubrum. Rose or pink, spotted darker; very beautiful. Price each, 2oc.; per doz, \$2 oo.

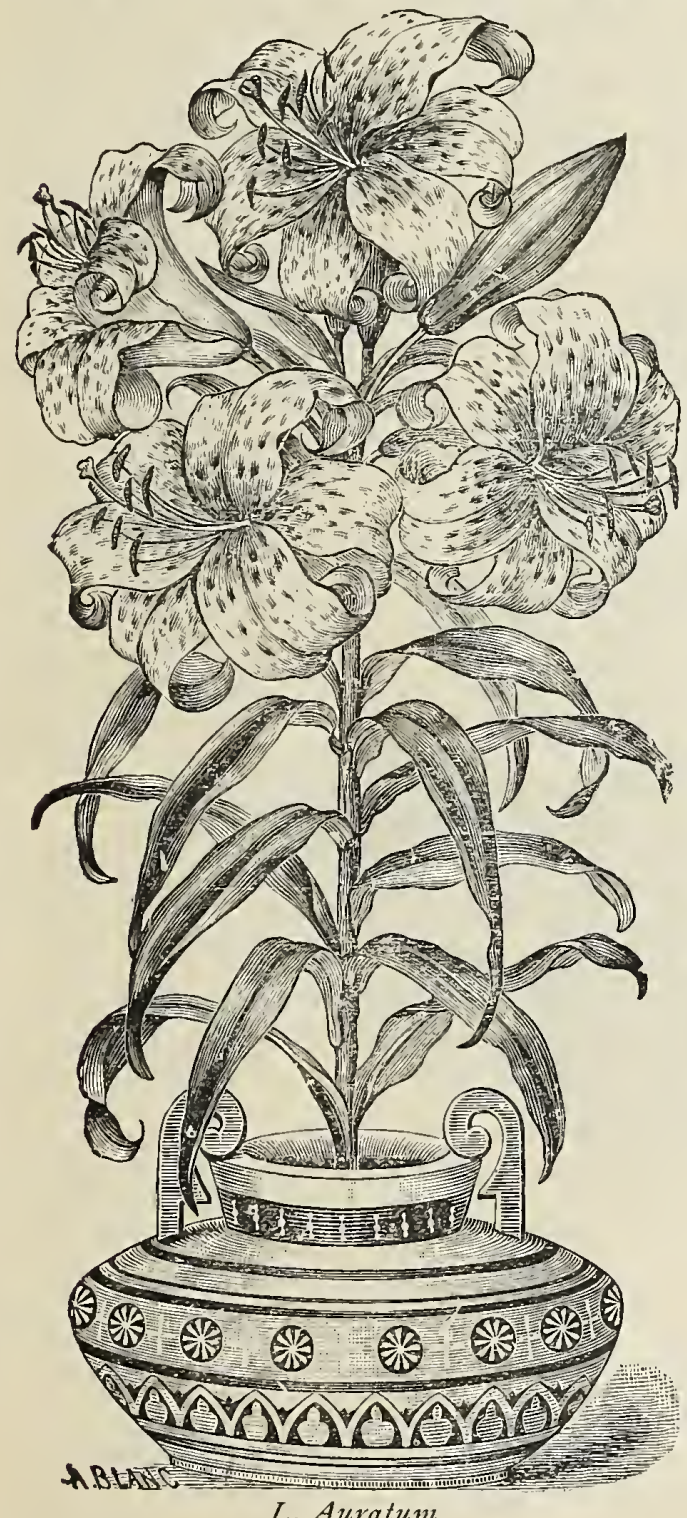

\section{Auratum.}

Monstrosum Album. Pure white, with immense clusters of bloom, often fifty in a bunch; grand. Price each, 25c; per doz., \$1.50.

Candidum. (Annunciation or St. Joseph Lily.) The well-known garden lily: snow-white, fragrant blossoms; it is also one of the best forcing lilies for florists. Three to four feet. Blossoms in the open ground about June. Price each, roc.; per doz., \$1.0o.
Longiflorum, Large white trumpet shaped flowers. Price each, I5c., per dozen, $\$ 1.50$.

Harisii, the Bermuda or Easter Lily. Flowers pure white and trumpet-shaped. Its great value consists in its earliness and free-blooning qualities, a single plant frequently producing from eight to twelve flowers at one time; extremely valuable for forcing, but not sufficiently hardy for out-door planting, unless well protected. First size bulbs, price each, 25c.; per dozen, \$2.50. Second size bulbs, price each, I5c., per dozen, \$I.5O. Third size bulbs, price each, Ioc.; per dozen, \$r.oo.

\section{HARDY ORNAMENTAL GRASSES.}

Very effective and picturesque groupings are made in parks and large lawns, and single plants are often used to great advantage in small areas.

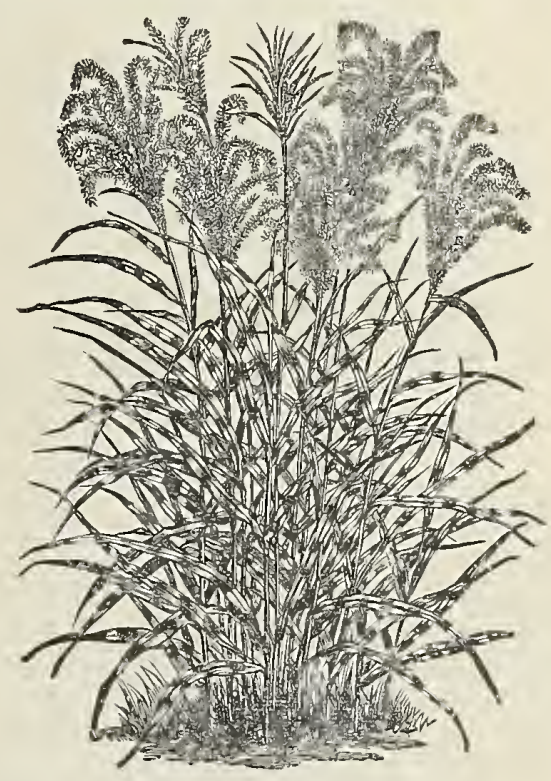

Eulalia Japonica Zebrina.

Arundo Donax. A magnificent hardy grass, growing to a height of fifteen feet, and forming dense clumps. Price, 25c. to $\$ 1$. oo each.

A. D. Variegata. A hardy, broad-leaved variegated Bamboo; foliage creamy white and green; growing six to eight feet high. Price, 25c. to $\$$ r.oo.

Bambusa Metake. (Japanese Bamboo.) A perfectly hardy variety of dwarf habit, attaining a height of not over five to six feet. The foliage is of a rich, dark green, and is retained on the plant in a fresh condition almost the entire winter. It makes a most desirable addition to the border in connection with shrubbery, or as an individual specimen for the lawn. Price, 5oc. to $\$ 1.00$.

Festuca Glauca. A pretty tufted grass with glaucous foliage, Price, $25 \mathrm{c}$. to $50 \mathrm{c}$, each.

Uniola Litifolia. One of the best of our native perennial grasses, growing from three to fonr feet high, with large flat flower heads in graceful drooping panicles. Price, $25 \mathrm{c}$. each; per dozen, $\$ 2.50$. 


\section{HARDY ORNAMENTAL GRASSES.}

\section{Continued.}

Eulalia Japonica Variegata. A very graceful, tall, ornamental grass from Japan. Its long, narrow leafblades are striped green, white and often pink or yellow. It throws up stalks from four to six feet in height, terminated with a cluster of flower spikes. Price, 25c. each; per doz., $\$ 2.50$; clumps, 5oc. to $\$$ I.OO.

E. Gracillima Univittata. This is a grand addition of compact habit, with very narrow foliage, of a bright green color with a silvery white mid-rib. Price, $25 \mathrm{c}$. each; per dozen, $\$ 2.50$; clumps, 5oc. to $\$$ I.OO.

\section{HARDY PHLOX.}

The Phloxes are among the most desirable of the hardy perennials; their large and very brilliant trusses of beautiful flowers comprise all shades of color, from white to crinuson, striped and mottled. Divide and replant in freshly prepared soil each alternate year. They delight in sunny situatious and a rich soil.

Bacchante. Dark crimson rose; large and fine.

E. Levavasseur. Fine dwarf white; extra early.

H.O. Wigers. Purest white with rich crimson eye.

Moliere. Salmon-pink with white eye.

Nettie Stewart. Fine, large, pure white, with just the faintest tinge of rose near base of petals.

Robert Werner. Soft, tender rose, with carmine center; very large and distinct from all others

The Pearl. The best late pure white.

Torpilleur. $\mathrm{Rich}$, bright magenta.

William Robinson. Rosy salmon, with large, dark center. Price each, I5c.; per doz., \$r.5o.

\section{Peonies.}

The Peonies are greatly prized on account of their large, vigorous, hea $1 \mathrm{th} y$, bushy form and abundance of magnificent bloom of large, bright, double flowers. They are extremely hardy, and may be planted either in fall or spring, growing well in any soil.

Whit e. Large double, pure white. Price, large root, 25c.; c $1 \mathrm{um} \mathrm{p}$ of roots, 5 oc.

Rose. Sweet scented. Price, large root, 25c.; clump of roots, $50 \mathrm{c}$.

Crimson. Very dark crim son. Price, large root, 25c.; clump of roots, 5 oc.

Mixed Colors. Price per doz., $\$$ r.5o.

E. Japonica Zebrina. This variety resembles japonica in hardiness, growth and bloom. The long blades are marked with broad yellow bands across the leaf. It makes a very attractive specimen plant for the lawn. Price, 25c. each; per doz., $\$ 2.5^{\circ} ;$ clumps, 5oc. to $\$ \mathrm{r} .00$.

Erianthus Ravennæ. A hardy ornamental grass, which grows from nine to twelve feet high, frequentlv throwing up from thirty to fifty flower spikes. It resembles the pampas grass, but blooms much more abundantly. Price, $25 \mathrm{c}$. each; clumps. 50c. and $75 \mathrm{c}$. Phalaris Arundinacea Variegata. (Variegated Ribbon Grass.) Large variegated foliage : an excellent grass for bordering large beds. Price, roc. each; per dozen, $\$ 1.00 ;$ per one hundred, $\$ 6$ oo.

\section{PEONY MOUTAN.}

\section{Iree Peonies.}

A beautiful group of hardy Japanese shrubs, having flowers of immense size, both single and double, varying in color from white to scarlet, splashed, spotted and striped in every conceivable manner. They form bushes four to five feet high, and as many through. In three sizes. Price, 5oc. and $\$ 1.00$ each. 


\section{MADEIRA VINE.}

The Madeira vine is a beautiful climber, with thick, glossy, light green leaves, climbing twenty feet or more, and twining in auy desired forn. Price each, 5c.; per dozen, 5oc.

\section{Tritoma, Flame Flower.}

\section{Torch Lily or Red Hot Poker.}

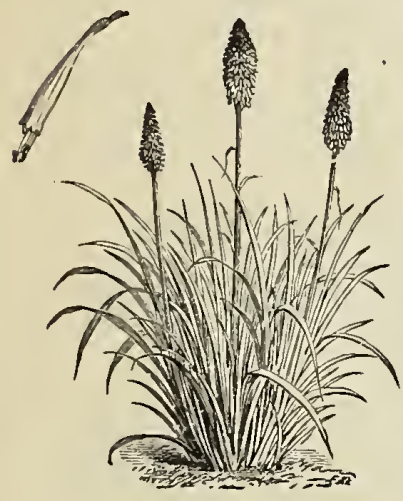

Tritoma, Flame Flower, Torch Lily or Red Hot Poker.

Blooms from midsummer till freezing weather. The stalks shoot up from three to four feet high, and continue blooming for several weeks. As the flowers bud, open and fade, they pass through the shades of yellow, red and blue, that a bar of hot iron does in cooling. Price e a ch, 25c.; per doz., $\$ 250$.

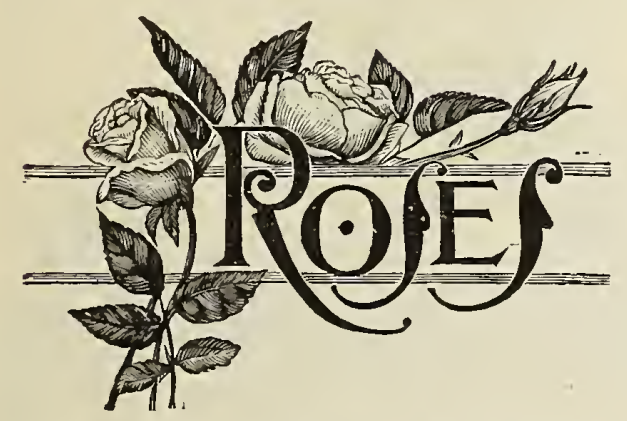

\section{HARDY HYBRID ROSES.}

The varieties given below and many recent introductions will be carried in stock for spring sales.

Culture. Roses require a $\mathrm{rich}$, well-drained soil, enriched with well-rotted manure. Applications of liquid manure during the growing season will stimulate a more vigorous growth.

Anne de Diesbach. Clear rose; large flowers; vigorous.

Coquette des Alps. White shaded rose. A very profuse blooner throughout the season.

Earle of Dufferin. Dark, velvety crimson.

General Jacqueminot. Velvety red. One of the niost widely known of hardy roses.

Glorie Lyonaise. A large white rose; very fine.

Harrison's Yellow. Golden yellow; medium size; semi.double.

Persian Yellow. Bright yellow, sniall, nearly full.
Mme. Gabriel Luizet. Silvery pink; vigorous grower. Mme. Plantier. Vigorous grower; summer bloomer. Paul Neyron. Immense size; pink; good, tough foliage.

Prince Camille De Rohan. Velvety crimson.

Ulric Brunner. Cherry red.

Prices: Selected two-year-old, each, 3oc.; per doz., $\$ 3.00$.

Extra selected two-year-old, each, 5oc.; per doz., \$4.5o.

Extra strong, transplanted, three-year-old, each, 75c.; per doz., \$7.oo.

\section{CLIMBING ROSES.}

Crimson Rambler. The plant makes a rapid growth of numy branches and smaller shoots, all of which bear clusters of bright crimson flowers. Price, $25 \mathrm{c}$, 5oc. aud \$I. oo each.

Yellow Rambler. (Aglaia.) A perfectly hardy yellow climbing rose. The flowers are of fair size and borne in large clusters. Price, 25c., 50c. and $\$ 1.00$ each.

Baltimore Belle. A beautiful rose, producing large clusters of double flowers, blush white, changing to light rose. Price, $25 \mathrm{c}$. to $50 \mathrm{c}$. each.

Queen of the Prairie. Large double flowers of a deep rosy carmine and very fragrant. Price, $25 \mathrm{c}$. to $50 \mathrm{c}$. each.

\section{CLIMBING SHRUBS.}

Ampelopsis Veitchii. ("Boston Ivy" or "Japan Ivy.") It is perfectly hardy, clinging to stones, brick or wood work with the greatest tenacity. In the summer the foliage is a rich shade of green, but in the fall it changes to gorgeous tints of scarlet, crimson and orange. Price, 2oc. each; per dozen, \$2.oo.

Ampelopsis Quinquefolia. The old Virginia creeper. Invaluable where a coarse, rapid climber is desired. The foliage is larger than the above. Price, $20 \mathrm{c}$. each ; per dozen, $\$ 2.00$.

Aristolochia Sipho. A vigorous and rapid-growing climber, bearing singular brownish colored flowers, resenbling in shape a Dutchmau's pipe. Price, $25 \mathrm{c}$. each; per dozen, $\$ 2.50$. Extra strong plants, 50c. each.

Bignonia Radicans. ( 7 rumpet Creeper.) A very rapid grower; flowers in large bunches, of a rich orange. scarlet. Price, $25 \mathrm{c}$. each; per dozen, \$2.25. Extra size plants, 5oc. each.

Clemalis Paniculata. (Japan's Sweet Clematis.) Its foliage is a rich glossy green. Flowers delicate, star like in form, and pure white, borne in large panicles and extremely fragrant A very rapid grower. Price, two-year plants, 3.5c. eaclı; per dozen, $\$ 350$. Extra three year plants, 5oc. each; per clozen, $\$ 5.00$.

Honeysuckle, Japan. Golden leaved. Price, 25c. to 5oc. eacli.

Honeysuckle, Chinese Evergreen. Fragrant; blooms all summer. Price, $25 \mathrm{c}$. to $50 \mathrm{c}$. each.

Honeysuckle, White Japan. Fragrant; a fine liealthy grower and profuse bloomer. Price, 20c. to 5oc. each.

Ivy, English. Invaluable fron the fact of remaining green throughout the year. Large plants. Price, $25 \mathrm{c}$. to 50c. each; smaller plauts, $25 \mathrm{c}$. each.

Wistaria, Sinensis. The favorite variety, producing thousands of pendulous clusters of delicate violetblue blossoms. Price, 25c. to 50c. each.

Wistaria Sinensis Alba. Of similar habit to Sinensis, with pure white flowers. Price, 25c. to 5oc. each. 
SHRUBS ANT DWARF ORPAMENTALTREES.

Althea, Double Rose or Rose of Sharon. Strong, erect-growing shrubs of the earliest culture, which bear large and showy flowers during the last half of summer. Price, 50c. to $\$$ r.oo each.

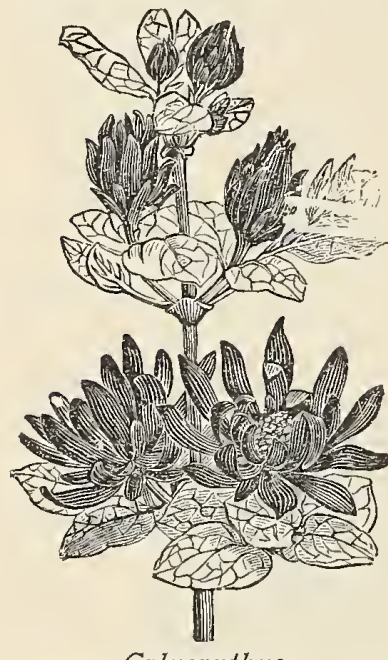

Calycanthus.
Althea, Double White. Like the rose, except in color. Price, 50c. to $\$ \mathrm{I} .00 \mathrm{each}$.

Calycanthus. (Strawberry scented shrub). Wood and flowers fragrant. Blossoms in June. Price, $25 \mathrm{c}$. to 5oc. each.

Deutzia Gracilis. Entirely hardy; flowers white. Price, 25c., 50c. and $\$$ I. oo.

Deutzia Crenata. Double white ; rose tinged. Price, 25c., 50c. and $\$$ r.oo.

Deutzia Scabra. A rapid growing single variety; flowers white, large. Price, $25 \mathrm{c}$. and $50 \mathrm{c}$.

Exochorda Grandiflora. A fuely-shaped shrub, with a profusion of pure white flowers, borne in racemes of five or six. Price, 5oc.

Forsythia. Leaves and branches deep green; flowers bright yellow. Blooms very early in spring. Price, $25 \mathrm{c}$. to $5 \mathrm{Oc}$.

Hydrangea Grandiflora. This is a beautiful shrub, with enormously large and dense flower heads, opening pure white, beconing tinged with rose color in their mature bloom. Blossoms profusely during the summer months; perfectly hardy. Price, 25c., 5oc. and $\$$ I.oo.

Japan Quince. ITas bright scarlet-crimson flowers in great profusion in early spring. Price, 25c., 50c. and \$r.oo.

Lilac, Common. The common purple species; good shrub. Price, 25 and 5oc.

Lilac, Common White. Flowers pure white; very fragrant. Price, $25 \mathrm{c}$. and $50 \mathrm{c}$.

Purple Fringe Smoke Tree. A shrub much admired for its curious fringe of hair-like flowers that covers the whole surface of the plant in summer. Price, 50c. each.

Rhododendrons. These are among the most valuable of our hardy flowering shrubs and cannot be surpassed for lawu decoration. The flowers range through shades of rose, pink, crimson, white, etc., six to twelve inches in diameter. Plants with four to eight buds. Price, $\$ \mathrm{I} .00$ to $\$ \mathrm{I} .50$.

Spirea Prunifolia. (Bridal Wreath.) Flowers in clusters, covering the whole length of the branches; white and very double; May. Price, 25c. to $50 \mathrm{c}$.

Spirea Reevesii. Double white. Blooms in large clusters, very fine. l'rice, $25 \mathrm{c}$. to $50 \mathrm{c}$.

Weigela Rosea Nana Variegata. One of the most conspicuous shrubs that we cultivate; leaves beautifully margined creamy white; flowers pink. Price, 25 c. to $50 \mathrm{c}$. each.
Van Houttei. The fiuest of all the wlite Spireas. A beautiful ornament for the lawn at any season, but when in flower it is a complete fountain of white bloom. Clusters of twenty to thirty flat white florets make up the raceme, and are set close along the drooping stems. Pricé, $25 \mathrm{c}$. to $50 \mathrm{c}$.

Japan Snowball. (Vibernum Plicatum.) Foliage corrugated, olive green through summer, but towards fall it turns much darker. Flowers, though hardly as large as the old variety, are much more numerous and pure white. There are ofteu as many as twenty balls on a branch eighteen inches long. Price, 5oc., $75 \mathrm{c}$. and \$I.OO.

Snowball. A favorite shrub, with clusters of white flowers. Price, 25c. to 5oc.

Weigela. An elegant shrub, with clusters of pink and white flowers. Price, $25 \mathrm{c}$. to $50 \mathrm{c}$.

HORSE CHESTNUT. Price, 50c. to $\$ \mathrm{r} .50$.

\section{HEDGE PLANTS AND EVERGREENS.}

California Privets. One to two feet. Price per dozen, $60 c$; per one hundred, $\$ 4.00$.

Two to two and one-half feet. Price per dozen, $\$ 1.00$; per one hundred, \$8.oo.

Two and one-lialf to three feet, bushy. Price per dozen, \$2 oo; per one hundred, \$5.00.

Arbor Vitae. (American.) Eight inches. Price per dozen, $\$$ r.oo; per one hundred, $\$ 5.00$.

Ten to twelve inches. Price per dozen, $\$ \mathrm{r} .5^{\circ}$; per one hundred, $\$ 7.00$

Eighteen to twenty-four inches. Price per dozen, $\$ 200$; per one hundred, \$12.00.

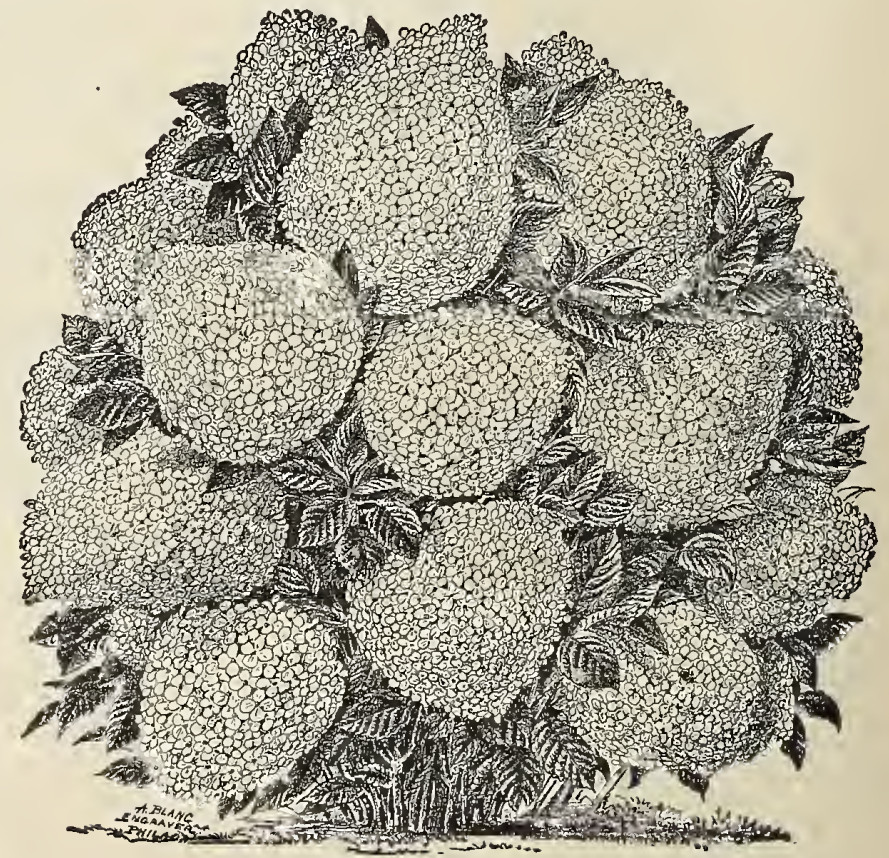

Hydrangea Grandiflora.
Arbor Vitae. (Siberian.) One foot. Price per dozen, $\$ \mathrm{r} .50$; per one hundred, \$10.00.

Eighteen to twenty-four inches. Price per dozen, $\$ 3.00 ;$ per one hundred, $\$ 20.00$. 


\section{HEDGE PLANTS AND EVERGREENS.}

\section{Continued.}

Hemlocks. One foot. Price perdozen, $\$ \mathrm{I} .50$; per one hundred, \$Io.oo.

Oue to one and one-half feet. Price per dozen, $\$ 3.00$; per one hundred, \$20.00.

One and one-half to two feet. Price per dozen, $\$ 4.00$; per one hundred, $\$ 30.00$.

Spruce. (Norway.) One foot. Price per dozen, $\$ 1.50$; per one hundred, \$10.0o.

Eighteen to twenty-four inches. Price perdozen, $\$ 250 ;$ per one hundred, \$I5.00.

Two to two aud one-half feet. Price per dozen, $\$ 3.50$; per one hundred, $\$ 25.00$.

\section{FRUIT TREES.}

Apples. Standard. Four to five feet. Price, $25 \mathrm{c}$.

Staudard. Five to seveu feet. Price, $40 c$.

Standard. Seven to nine feet. Price, $75 \mathrm{c}$.

Dwarf and Crab. Price, 3oc.

Pears. Standard. Four to five feet. Price, 5oc.

Standard. Five to six feet. Price, $65 \mathrm{c}$.

Standard. Six to eight feet. Price, $\$$ I. oo to $\$ 1.50$.

Pears on Quince Stock. Four to five feet. Price, 5oc. to $75 \mathrm{c}$.

Cherries. Four to five feet. Price, 5oc.

Five to seven feet. Price, 65 c.

Extra size. Price, 75 c. to $\$ 2.00$.

Peaches. Two to four feet. Price, I $5 \mathrm{c}$.

Four to six feet. Price, $25 \mathrm{c}$.

Six to eight feet. Price, 5oc.

Plums. Abundance, Lombard, Washington. Price, 5oc. to $\$ 1.00$.

Quinces. Three to four feet. Price, $40 c$. Four to six feet. Price, 6oc.

Large sizes. Price, $75 \mathrm{C}$. to $\$ \mathrm{I} .00$.

\section{VEGETABLE PLANTS AND ROOTS.}

We grow large quantities of vegetable plants and roots, and can supply all the varieties listed below in their proper season.

Artichoke. (Jerusalem.) Price, 25c. per qt.; per pk., $\$ 1.00$.

Asparagus. (Conover's Colossal.) 'Two years old. Price per oue hundred, \$I.0o; per one thousand, $\$ 5.00$.

Asparagus. (Barr's Mammoth.) Price per one hundrfd, $\$$ I.oo; per oue thousand, $\$ 5.00$.

Asparagus. (Palmetto.) Price per one hundred, $\$ 1.00 ;$ per one thousand, $\$ 5.00$.

Cabbage Plants. (Hot-bed) Ready after April Ist. Harly Jersey Wakefield, Farly Drumhead, Succession. Price per one hundred, 5oc.; per one thonsand, $\$ 4.00$.

Cauliflower Plants. (Hot-bed.) Price per doz., I5c.; per one hundred, \$I.oo.

Celery Plants. Ready July Ist. Golden Self-Blanching, Goldeu Dwarf, White Plume, Giant Pascal, etc. Price per doz., Ioc.; per one hundred, 5oc.; per one thousand, $\$ 4 . c 0$.

Chives. For flavoring. Price per clump, Iоc.; per doz., \$1.00.

Egg Plants. Ready in May and June. New York Improved Large Purple. Grown in pots. Price per doz., 35c. and 75c.; per one hundred, $\$ 4$.oo.

Fennel Roots. Three years old. Price each, Ioc. to 25c.; per doz., \$I.oo and \$2.0o.

Hop Vine Roots. Price per doz., 5oc.; per one hundred, $\$ 2.50$

Horse Radish Sets. Price per doz., Ioc.; per one hundred, 5oc.; per one thousand, \$3.00.

Lettuce Plants. Ready in April and May. Price per doz., Ioc.; per one hundred, 5oc.

Pepper Plants. Ready in May and June. Large Sweet Mountain. Price per doz., I5c.; per one hundred, \$I .oo.

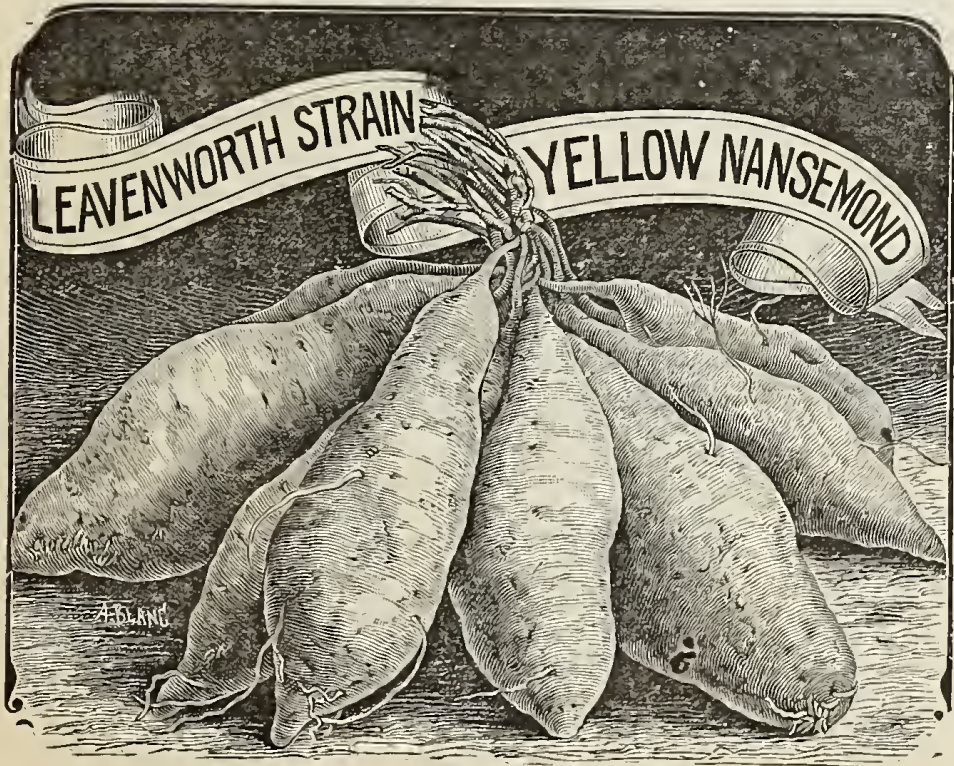

Sweet Potatoes.
Rhubarb Roots. Linnæus and Victoria. Stroug roots; price each, 20c.; per doz., \$2.00. Small roots, each, I5c.; per doz., \$I.5o; perone hundred, \$I o.00.

Sage. Broad leaf. A large-leaved variety. Price each, I5c.; per doz., \$I.oo.

Sweet Potato Plants. Yellow Nausemond. Price per bunch of twenty-five, 2oc.; per one hundred, 5oc.; per one thousaud, \$4.0o.

Sweet Potato Plants. Red Nansemoud. Price per bunch of twentyfive, 2oc.; per one hundred, 5oc.; per one thousand, $\$ 4.00$.

Tomato Plants. Ready in May aud June. We can always supply through season well-grown plants of the leading varieties. Price per dred, \$I.0o and \$I.25.

Wormwood Roots. Price each, 25c.; per doz., \$2.0o.

AF्ञ Special quotations on application for large quantities. doz., I5c. and 20c.; per one hun- 


\section{VIMES.}

Agawam. Large ; dark red; sweet. Price each, 25c.; per doz., \$2.50.

Brighton. Berry m e diu m size ; color, light red. Price each, 25c.; per doz., $\$ 2.50$.

clinton. A small black grape, very hardy and excellent for wine. Price each, 2oc.; per doz., \$2.00.

Concord. Very hardy and good quality; the best for general culture. Price each, 20c.; per doz., \$2.0o.

Eaton. Bunch very large, compact, often doubleshouldered; berries very large, round, black, covered with a heavy bloom; adheres firmly to the stem. Price each, 35c.; per doz., \$3.0o.

Golden Pocklington. The

vine is a strong grower; never mildews. The fruit is of a light golden yellow; berries round, very large and thickly set on a bunch. Price each, $25 \mathrm{c}$; per doz., $\$ 2.50$.

Green Mountain. A white grape. Bunch medium to long, irregular; stem long above bunch; berry medium; pale green. Price each, 35c.; per doz., \$3.00.

Lindley. (Rogers No. 9.) A red grape of the best quality, and one of the most desirable of Rogers' Hybrids. Ripens with Concord, and keeps well; medium to large in bunch and berry; flesh tender, sweet, and of a high, aromatic flavor. Vine vigorous, hardy and healthy. It seems to be more productive when mixed with other varieties. Price each, 25c ; per doz., $\$ 2.50$.

Merrimac. (Rogers No. Ig.) Black, vigorous growth, and large, sweet fruit. Price each, 25c.; per doz., $\$ 2.50$.

Moore's Diamond. White; bunch large, compact, shouldered; berries large, round; skin thick, firm. Vine a good grower, with healthy foliage. Price each, 25c.; per doz., \$2.50.

Moore's Early. Ripens early. The bunches are large and compact; berries large, black, and good flavor; strong, healthy grower, an immense bearer. Price each, $25 \mathrm{c}$.; per doz., \$2.50.

Niagara. Bunches very large and compact; berries large as Concord, mostly round; light greenish white, slightly ambered in the sun. Price each, $35 \mathrm{c}$.; per doz., \$3.0o.

Worden. Iarge, black, early and very productive. Price each, $25 \mathrm{c}$.; per doz., $\$ 2.50$.

The varieties of grape vines have become so $n \mathbf{u -}$ merous that I catalogue only those that have proved most valuable and desirable in this vicinity, but can supply any of the others if wanted.

\section{STRAWBERRIES.}

Bubach. Very strong, healthy, vigorous plant. Very productive, large berries, and ripens early. Price per doz., 3oc.; per one hundred, \$I.50.

Crescent. (P.) Bright scarlet, immensely productive, early and profitable. Berries medium size. For near markets a profitable variety. Price per doz., 3oc.; per one hundred, \$1.50.

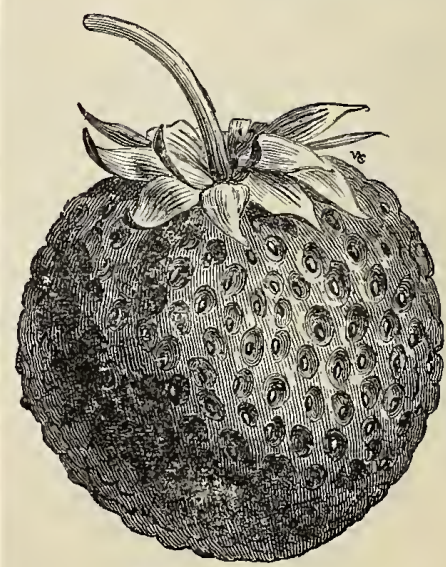

Marshall Strawberry.
Marshall. Very large, rou nd, d a r k crimson; very vigorous and productive; medium to late. Price per doz., 3oc.; per one hundred, \$1.50.

Mary. The ber. ries are conical in form with. blunt apex, exceptionally uniform in size and $\mathrm{s} h$ a pe, d e e p crimson color, and of rich, high quality. Price per doz., 40c.; per one hundred $\$ 2.50$. 


\section{STRAWBERRIES.}

\section{Continued.}

Sharpless. Very large, irregular berries of a good flavor. Very productive. Price per doz., 30c.; per one hundred, $\$$ I.50.
Rio. (Perfect.) This is a good early variety, strong, healthy foliage, perfect blossom, fruit large size, evenly colored and firm enough. Price per doz., 25c.; per one hundred, \$I.5o.

Parker Earle. The plant is a robust grower, with perfect flowers, berries large, conical, regular and uniform, glossy crimson, flesh firm, and in quality excellent. Price per doz., 30c.; perone lundred, $\$$ I 50

\section{RASPBERRIES.}

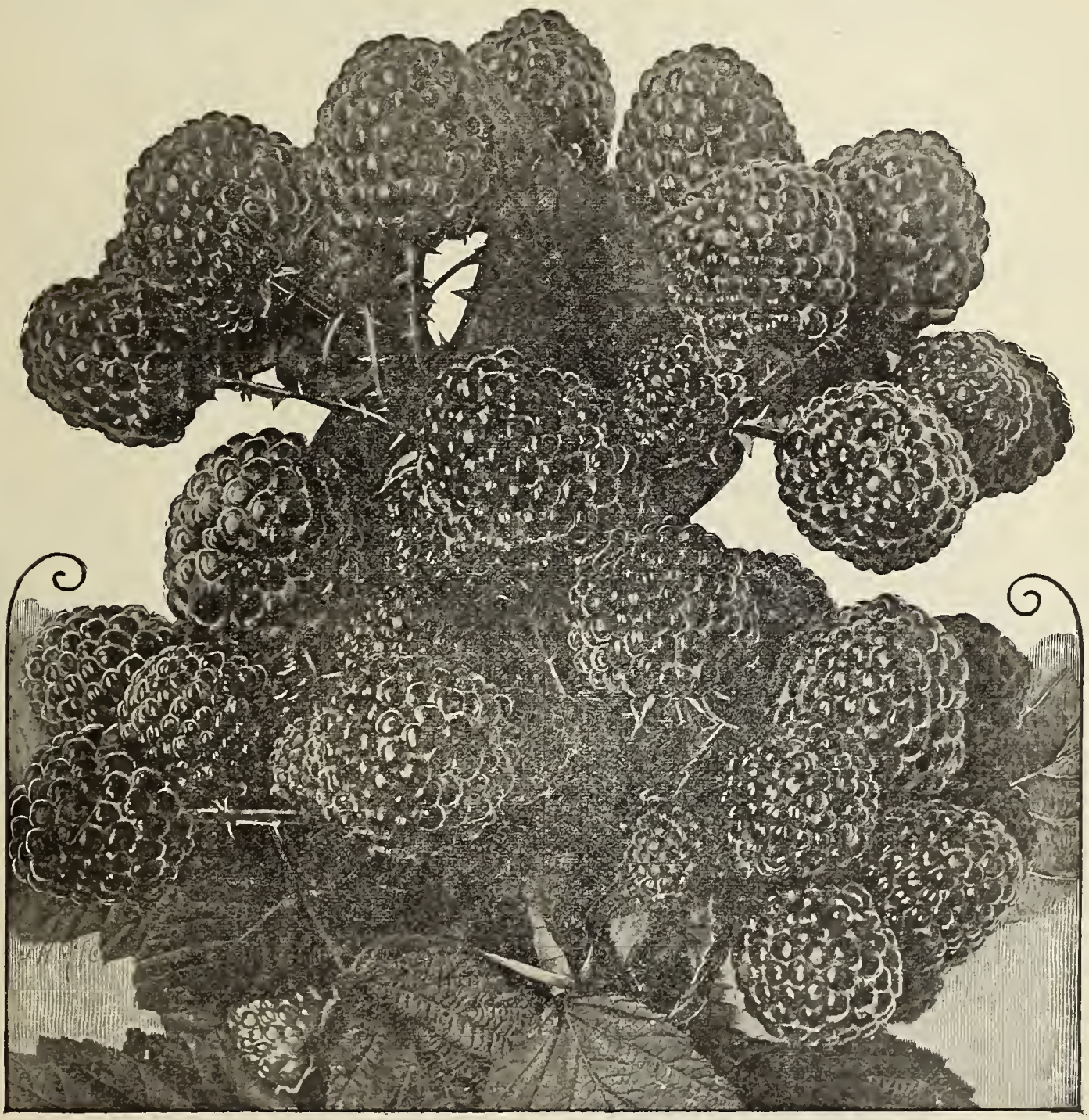

Cumberland.

Cumberland. This is a very hardy and the most profitable market variety, because of its immense size, firmuess and great productiveness. Price each, IOc.; per doz., \$1.00; per one hundred, $\$ 6.00$.

Cuthbert. Canes hardy and strong, with large healthy foliage, exceedingly productive. Berries large red, firm and of good flavor. Price per doz., 75c.; per one hundred, $\$ 4.00$.
Gregg. (Black Cap.) Canes of strong, vigorous growth, very productive; berries large, covered with heavy bloom, firm and fine flavor. Price per doz., 75c.; per one hundred, $\$ 4.00$.

Golden Queen. A yellow raspberry, of large size, great beauty, high quality, hardiness and productiveness. Price each, Ioc.; per doz., 75c.; per one hundred, $\$ 4.00$. 
BLACKBERPIES.

Kittatinny. Very large and of excellent flavor. Price per doz., 75c.; per one hundred, $\$ 4.00$.

Lawton. Very large, juicy and sweet. Price per doz., $75 \mathrm{c}$; ; per one huudred, $\$ 4.00$.

Snyder. Very productive. Flavor rich and good, ripens early. Price perdoz., 75c.; per one hundred, $\$ 4.00$.

\section{CURRARTS.}

Fay's Prolific A red variety, very large and productive. Price each, Ioc.; per doz., $\$ 1.00 ;$ per one hundred, $\$ 6.00$.

Red Cherry. Large aud fine for market. Price each, Ioc.; per doz., \$I OO; per one huudred, $\$ 5.00$.

White Grape. The best white currant. Price each, Ioc.; per doz., \$I.Oo; per one hundred, $\$ 6.00$.

Black Naples. For jams and jellies. Price each, Ioc.; per doz., $\$$ I.oo; per one hundred, $\$ 6.00$.

\section{GOOSERERTRES.}

Downing. Fruit large, pale green, and of excellent quality. Price each, 20c.; per doz., $\$ 2.00$.

Houghton. Medium size, light red fruit. Price each, 20c.; per doz., $\$ 2.00$.

Industry. Large, dark red fruit of excellent quality. Price each, $25 \mathrm{c}$.; per doz., $\$ 2.50$.

\section{WHITE BLAGKBERRY. "GCEBERG:"}

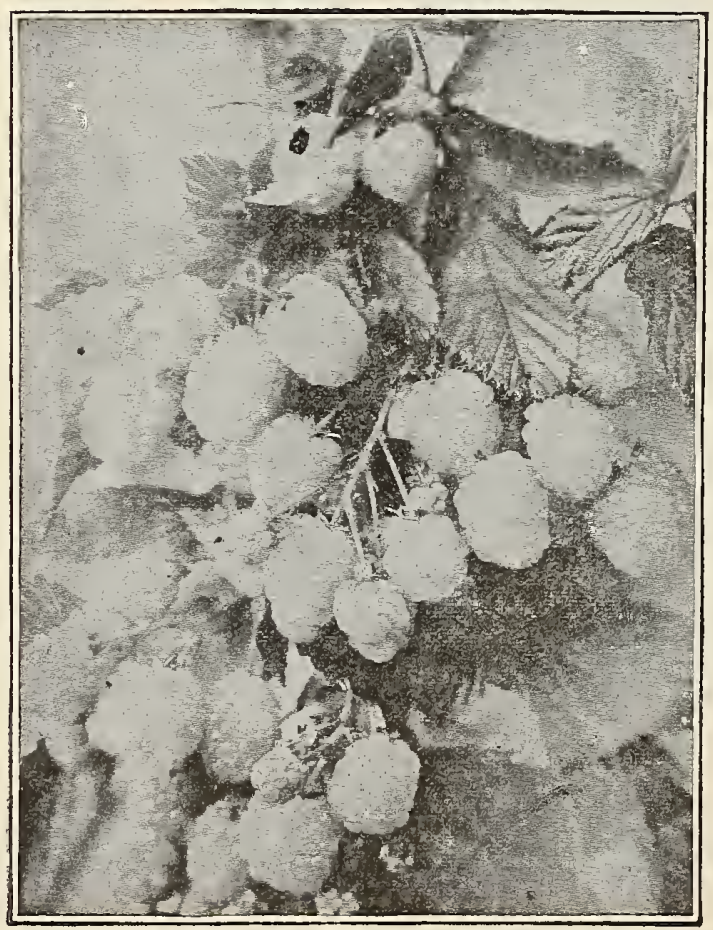

Originated by Luther Burbank, who describes it as follows: "One of the great grandparents of 'Iceberg' was Lawton. The first generation of seedlings, when crossed with Crystal White, was all black; the second also, though varying much in other respects; but the third produced this wonderful plant, bearing the snowiest white berries ever seen.

"Very little attention was paid to the long rows of cross-bred desceudants, until one day this berry was discovered among its black relatives, with the canes bending in various directions with their load of delicious, snowy berries, which are not ouly white, but so transparent that the seeds, which are unusually $s$ mall, may be seen in the berries when ripe. Clusters larger than those of Lawton; berries, as near as could be judged, were at least as large, earlier, sweeter, and more tender and melting throughout, though as firm as Lawton is when ripe."

Price each, IOc.; per doz., \$I.oo; per one hundred, \$8.oo.

\section{MESCT}

\section{EXTERMIIRATORS.}

\section{BUG DEATH}

Is a non-poisonous article, but it is sure death to the potato, squash and cucumber bugs, currant and tomato worms and many other plant-eatiug pests.

It is a plant food of great merit, a benefit instead of injury to all plants, and prevention of blight or rust to the potato tops, keeping the tops healthy until the potato fully niatures.

It may be applied either dry or in solution. When the former method is employed, the early morning, while the plants are wet with dew, is the best time. The manufacturers recommend its application in water, and claim much better results, also stating that

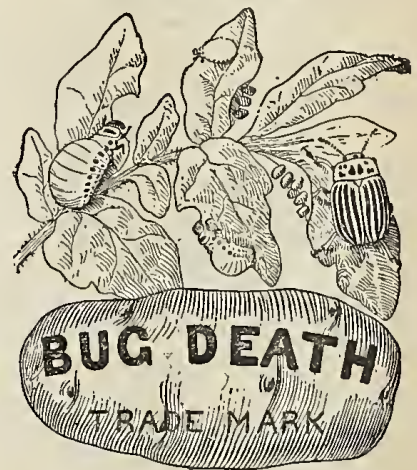

Pat. March 16 and Nov. 9, I897.

Pat. in Canada Nov. 2, 1897 . in connection with Bordeaux Mixture it has proved of great advantage.

Use Bug Death liberally on rose bushes, house plants, shrubs, etc.; the results will be marvelous. It is the best powder on the market for hen lice.

It is perfectly safe to handle. Will not injure stock or animals in the least. Must be kept perfectly dry, so it will not clog in the shaker.

The experience of those who have used Bug Death shows conclusively that the extra yield in the crop more than pays the entire cost.

Price per one-pound package, I5c.; three-pound package, 35c.; five-pound package, 50c.; twelve-andone-half-pound package, $\$$ I.oo.

Spanish Pink. A vegetable compound. Contains no chemicals. safe to apply on all garden vegetables. Kills cabbage and currant worms, slugs, bugs, etc. Price per one-pound can, 2oc.

London Purple. One of the best destroyers for insects. The proper proportions for using are at the rate of one pound to I50 gallons of water. Price per pound, 2oc.; ten pounds, $\$$ I.75. 


\section{INSECT EXTERMIRATORS. \\ Continued.}

Hellebore. A powder used for destroying insects on plants and buslies. Price per oz., 5c.; per onefourth pound, $10 \mathrm{c}$.; per pound, $25 \mathrm{c}$; per five ponnds, $\$$ I.OO.

Sulphur. For the extermination of fungii and mildew on grape vines and other plant foliage. Price per ponnd. $8 \mathrm{c}$.; per one hundred pounds, $\$ 5.00$.

Slug Shot. To destroy potato bugs, and those on tomato and egg plants, currant worms, cabbage lice and worms, flea beetles and striped bugs on melons, squash, turuips, beets, onions, etc.; canker worms and caterpillars on fruit and ornamental trees. Five and ten-pound packages, 5c. per found. In barre1 lots (225 to 260 pounds per barrel), $4 \mathrm{c}$. per pound.

H a m mo nd's Grape Dust is a preparation to $\mathrm{k}$ ill the de. structive mil. dew thatstrikes the grape vine, affecting leaves, fruit and stems in unfavorable seasons. Also for like use upon any other plants or trees affected $w$ it h mold, mildew or rust mites, and for any use where a fumiga-

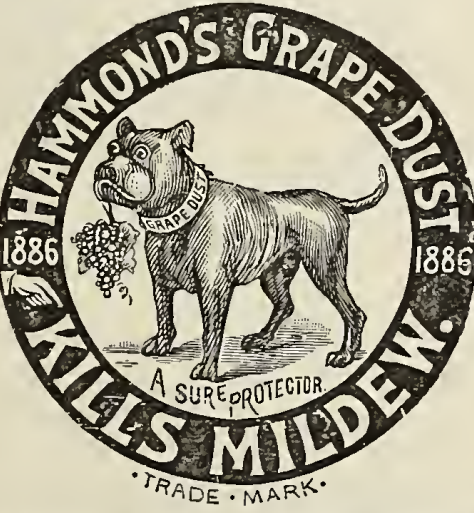
tor or antiseptic is required, either iu greenhouses or in the open air. Price, five-pound package, $35 \mathrm{C}$; $\mathrm{keg}$ of one hundred pounds, $\$ 5.00$.

Paris Green and Fungiroid. Half and half; ready for use against fungii and insects. Price, $25 \mathrm{C}$. per pound; five pounds, $\$ 1.00$.

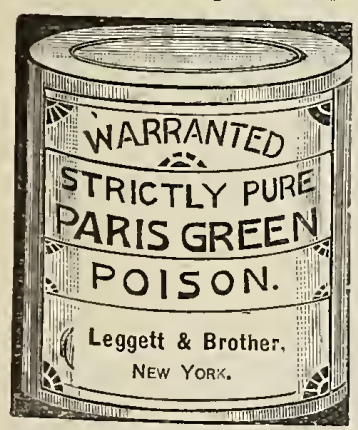

Paris Green. The most practical and generally employed substance for destroying the potato bug and other insects. Strictly pure. Price per pound, 25c.; five pounds for $\$ 1 . n o ; \$ 18.00$ per one huudred pounds.

Fungiroid. Prevents blight and mildew, and mixed with Paris Green is a valuable combination against slugs, bugs, wornis and fungii. Price, two sizes, I $5 \mathrm{c}$. and $75 \mathrm{c}$.

Tobacco Dust. This is tle leaf and refuse of tobacco mannfacture, ground to a fine powder and a specific for aphis, fleas, beetles, etc. It is also a good fertilizer and preventive for insects in the gronnd and about roots. Price per pound, roc.; five pounds, $25 \mathrm{c}$; by the barre1, $\$ 3.00$; per one hundred pounds.

Tobacco and Sulphur Insecticide and Fertilizer. It will destroy rose bugs, lice, cut worms, vine bugs, tomato worms, currant wornis, cabbage lice and para. sites of all descriptions. Mix thoronghly with earth in pots, or in the hills, one part powder to five parts earth. Easy of application, and will not burn or injure the plants. Earth worms will not live where this is used. In $25 \mathrm{c}$. and $50 \mathrm{c}$. packages.
Whale Oil Soap. For removing and preveuting the ravages of insects, grubs, slugs, etc., on trees, plants and vines. Dissolve at the rate of one ounce of soap to a gallon of water, and syringe the plants every day or two until the insects are removed. Price per package, containing one pound, I5c.; eight ponvds, \$I.oo; one hnndred ponnds, \$6.00.

Carbolic Disinfecting Soap. For washing horses, cattle, dogs, pigs and other domestic animals (except cats). Use like other bng soap, rubbing it well in, aud allow the solution to dry on the animal; or dissolve one onnce of soap in one ounce of boiling water, and when snfficiently cool, use freely with sponge or brush. Price per package, 2oc.; per pound, 7oc.

Tobacco Soap. An excellent specific for the destructiou of plant-infecting insects and parasites. Is equally valuable for removing rermin from animals, furniture, etc. Price, per one-half-pound bar, 2oc. each.

Nikoteen is used either by fumigating or spraying. Is composed of that element iu tobacco whicl gives it its value as an insecticide and nothing else. Is recommeuced by the United States Department of Agriculture and by all horticultural authorities as the best remedy for nost of the insects that attack plants and flowers. One part of Nikoteen to six hundred parts of water is a snfficiently strong spraying solution for all insects except scale on palms. For scale the solntion may be used one part Nikoteen to four hundred parts water. Price per pint bottle, $\$$ I.oo.

Aphis Punk is specially designed for nse in private places. It is very effective as an insecticide and so easy of application that its advantages in this respect are instantly apparent to the user. The Punk is liglited with a match and allowed to burn, which it does withont flaming, at the same time giving off dense white fnmes of nicotine that kills aphis and thrip very effectively. The fumes from A phis Punk contain no ammonia, the element in tobacco smoke that damages sensitive plants, so that is can be used anywhere withont danger of injuring the most delicate blooms. A box coutains one dozen rolls, each containing sixty grains of nicotine-snfficient for fumigating six hundred feet of floor space in houses of ordinary height. Price per box, 6oc.

Persian Insect Powder. This is powder made from the flower of the Russian Pyrethrum, and valuable as a poison for lice on plants, water bugs, roaches, bed bugs, etc. Price per pound, foc.

Gishurst's Compound. A certain remedy for green fly, scale, mealy bugs, etc., etc. Price per ponnd, $50 \mathrm{c}$.

Kerosene Emulsion. Manufactnred on the most approved formula. Not injurious to foliage and a snre remedy for lice, scale and other insect pests. Price per quart can, 3oc.; gallon, 9oc.; five-gallon, $\$ 3.75$.

Soluble Fir Tree Oil. For destroying all insects al1d parasites that infest fruit trees, plants and anin1als,

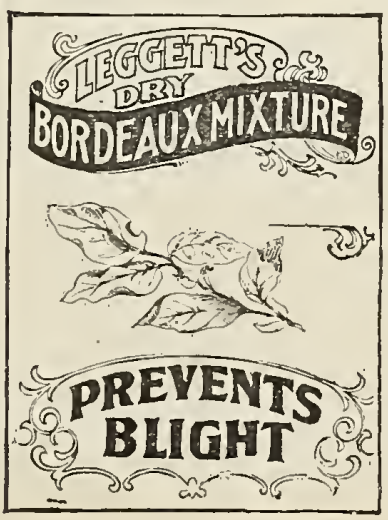
whether on the foliage or at the roots, such as nealy bugs, Anıerican blight, red spider, scale, thrip, green or black fly, woolly aphis, caterpillars, grubs, ants, worms, lice, fleas, etc. Price per halfpiut, 4oc.; per pint, $75 \mathrm{c}$; per quart, $\$ \geq .25$.

Bordeaux Mixture. Ready for immediate use by adding water. Forty-nine gallons of water to one gallon of mixture. Price per quart, 4oc. ; per gallon, $\$ I .00$. 


\section{INSEGT \\ EXTERMANATORS.}

Continued.

y Fluid or Cattle Comfort. Save your horses, cattle and other animals from tortures of flies, midgets, mosquitoes and other insects. Price per pint, 25c.; quart, 5oc.; gallon, $\$ 1.25$.

\section{FERTILIZERS.}

\section{Feed Your Plants and See Them Grow.}

Essex Flower Food. It produces rapid growth, rich foliage, and generous and perfect flowering. Price, small size, Ioc.; large size, $25 \mathrm{c}$.

Bowker's Food for Flowers. An excellent fertilizer for house plants. Easily applied by dissolving in water. Clean to handle, witlout odor; produces rich, green growth, and profusion of flowers. Price, small packages, Ioc.; large packages, enough for twenty plants one year, $25 \mathrm{c}$.

Lawn Dressing. This dressing is so prepared that it acts gradually through the season, producing a luxuriaut growth of grass of rich, green color. Tenpou ud bags, for I,000 square feet, 50c.; twenty-fivepound bags, for 2,000 square feet, $\$ 1.00$; one hundred pouuds, for one-quarter acre, $\$ 3.00$; per ton, $\$ 50.00$.

- A = Superphosphate. Benefits the crops more quickly than with any other form of bone, and on account of its really available properties promotes early niaturity, and it is invaluable for most crops, affording constant nourishment during their entire season's growth. Quantity required for garden and field crops, 500 to 600 pounds per acre; for garden crops it is best drilled in at seed-sowing time. For top dressing grass, 600 pounds per acre. Price per one hundred pounds, $\$ 2.50$; per ton, $\$ 40.00$.

Harvest Home Bone Phosphate. A good fertilizer for grass on gardeu crops, quick in action, requiring 600 to 800 pounds per acre. Price per one hundred pounds, $\$ 2.00 ;$ per ton, $\$ 30.00$.

Pure Pulverized Sheep Manure. A pure natural manure, and most nutritious for plants. Its effect is immediate and lasting. Excellent for mixing with the soil for greenhouse plants (one part manure and six parts soil). Strewn over and dug into the vegetable garden, or placed directly in drills or hills, it promotes a rapid, steady growth until maturity. It makes rich, safe and quick liquid manure; one pound to five gallons of water can be used daily, if necessary, with safety. Price, five pounds, $25 \mathrm{c}$.; ten pounds, 5oc.; per one-hundred-pound bag, \$2.50; per ton, twenty bags, $\$ 25.00$.

Ground Bone. This is for general fertilizing purposes and valuable on the lawn, meadow or in the garden. The finer particles are immediately beneficial, the coarse keeping up the supply of plant food for a loug period. Price, six pounds, 25c.; twentyfive pounds, $75 \mathrm{c}$.; per one-hundred-pound bag, $\$ 2.50$; per ton of two thousand pounds, $\$ 35 \cdot 00$.
Land Plaster or Gypsum. It is an excellent addition to land requiring lime and sulphates, particularly for such crops as turnips, potatoes, grasses and clovers. Its fertilizing action is not so much due to its value as a plant food, as to its absorbing and fixing ammouia, and rendering soluble the inert plant foods of the soil so that the growing crops can take them up. Quantity required, broad-casted and harrowed in, one-half to one ton per acre. Price per oue-hundred-pound bag, $75 \mathrm{c}$.; per ton, $\$$ Io.oo.

Hard Wood Ashes. Contain all fertilizing elements except nitrogen. They drive away insects, and are beneficial for all crops requiring potash. They are also very good for garden and field crops, and are of high value for cabbage, potatoes, onions, strawberries, fruit trees, grass-lands and lawns. Apply one to two tons per acre. Price per barrel, about two hundred pounds, $\$ 2.00$; per ton (two thousand pounds), in barrels, $\$ 18.00$.

Nitrate of Soda. This is valuable solely for the nitrogen it contains. It is very quick in action and hastens the maturity of crops. Being extremely soluble, it should not be applied until the plants are above ground, when one hundred to five hundred pounds per acre, mixed with wood ashes or land plaster, for convenience in applying, are generally used. Price per five-pound package, 3oc.; ten-pound package, 5oc.; per one hundred pounds, $\$ 4.00$.

Muriate of Potash. Eighty per cent. pure, equivalent to 48 to 50 per cent. actual potash. A high-grade fertilizer, and one of the best orchard fertilizers known. Especially adapted for all stone fruits, and as a general fertilizer. Muriate of potash and ground bone stands as a leader. Five pounds, 3oc.; ten pounds, 50 cents; twenty-five pounds, $\$$ r.oo; one hundred pounds, $\$ 3.00$. Original sacks of 224 pounds, $\$ 5 \cdot 5$ o. 


\section{FOR THE BIRDS.}

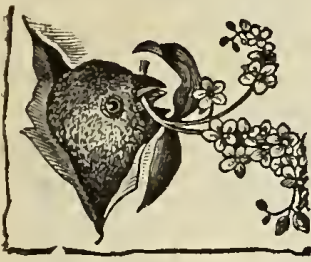
$25 \mathrm{c}$.

Millet, French. Price per pound, I5c.

Millet, American. Price per quart, Ioc.; three quarts, $25 \mathrm{c}$.

Hemp Seed. Price per quart, Ioc.; three quarts, 25c.

Sunflower Seed. Price per quart, roc.; three uarts, $25 \mathrm{c}$.

Maw Seed. Price per pound, $25 \mathrm{c}$.

Padda or Unhulled Rice. Price per pound, Ioc.

Mocking Bird Food. Price per bottle, $25 \mathrm{c}$.

Meal Worms. Price per one hundred, 5oc.

Canary Powder or Song Restorer. Price per bottle, $25 \mathrm{c}$.

Audubon's Bird Tonic. Price per bottle, 25c.

Peter's Treat. Price per roll, Ioc.; per dozen rolls, $\$ 1.00$.

Bird Gravel. Price per quart box, $5 \mathrm{c}$.

Cuttle Fish. Price each 3c., two for 5c.; per pound, $50 \mathrm{c}$.

Peas. Round, white; for pigeons. Price per quart, roc.; per bushel, \$1.50.

\section{POULTRY SUPPLIES.}

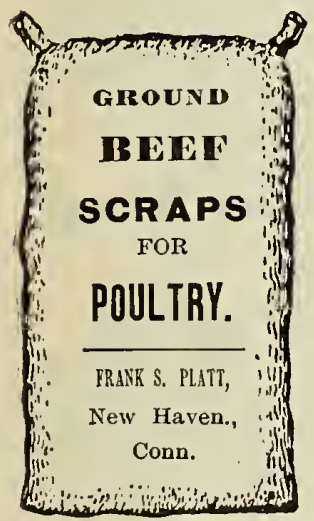

Price per one hundred pounds, $\$ 2.50$.

Price per twenty - five pounds, $75 \mathrm{c}$.

Price per five pounds, 25c.

\section{ANIMAL MEAL.}

Price per one hundred pounds, $\$ 2.50$.

Price per twenty-five polunds, $75 \mathrm{c}$.

Price per five pounds, $25 \mathrm{c}$.
Best Canary Bird Seed. Price per quart, I5c.; two quarts,

Best Mixed Canary Bird Seeds. Price per quart, ${ }_{5}$ c.; two quarts, $25 \mathrm{c}$.

German Rape. Price per quart, I5c.; two quarts, $25 \mathrm{c}$.

\section{BONE MEAL.}

Price per one hundred pounds, $\$ 3.00$.

Price per twenty-five pounds, $\$ 1.00$.

Price per five pounds, $25 \mathrm{c}$.

CRACKED BONE.

Price per one hundred pounds, $\$ 2.50$.

Price per twenty-five pounds, $75 \mathrm{c}$.

Price per five pounds, $25 \mathrm{c}$.

Mica Crystal Grit. Price per pound, 2c.; per one hundred pounds, \$r.oo.

White Lime Rock Grit or Egg Lime Grit. Price per pound, 2c.; per one hundred pounds. $\$$ I.oo.

Clover Meal. This is Clover Hay cut and ground to a consistency of coarse meal, and in combination with other poultry foods, fed in the morning mash, forms an invigorating and nourishing ration. Price per five pounds, $25 \mathrm{c}$.; per twenty-five pounds, $75 \mathrm{c}$; per one hundred pounds, $\$ 2.00$.

Cut Clover. It is the second crop or rowen of the Clover Hay; cut to proper length for mixing with the scalded food for the morning mash, and when fed hot with a little $E g g$ Producer is sure to result satisfactorily to the egg basket. Price per fifty-pound sack, \$1.25; per one-hundred-pound sack, \$2.00.

\section{ITPERIAL EGG FOOD. \\ For All Varieties of Poultry.}

Laying Hens, Young Chicks, Ducks and Turkeys. Will wake hens lay winter and summer, support fowls during moulting, keep them constantly in fine condition and increase their profit roo per cent. Half of the chicks die annually; this makes bone and muscle early and will save them.

Package to mix with fifty pounds of ordinary feed, $50 \mathrm{c}$; larger for $\$ 1.00$ and $\$ 2.00$. Sent prepaid on receipt of price.

\section{RUST'S EGG PRODUGER.}

As Rust's Egg Producer makes eggs plentiful and keeps fowls vigorous and healthy, it is just what is needed to make poultry keeping the most profitable operation on a farm or place. Price per one pound box, 25c.; per two-and-one-half-pound box, 5oc.; per six-pound box, $\$ 1.00$; per ten-pound box, $\$ 1.50 ;$ per twenty-five pound keg, $\$ 3.50$. (If by mail, add I6c. a pound for postage.

\section{Rust's Havens' Glimax} Gondition Powder.

Price per ten-barrel lots, F. O. B. cars, at $\$ 1.00$.

\section{GROUND OYSTER SHELLS.}

Price per ton, $\$$ ro.oo.

Price per one hundred pounds, in bags, $75 \mathrm{c}$.

Price per ten pounds, in bags, $25 \mathrm{c}$.

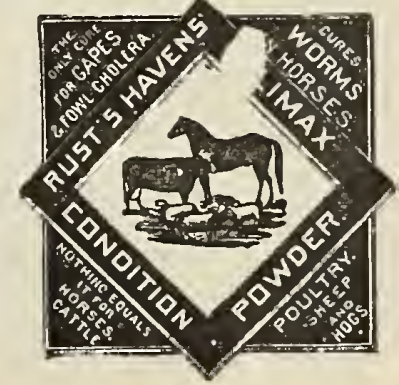




\section{POULTRY SUPPLIES. Continued.}

It is highly concentrated to make the dose small. It is not a food, but a honest medicine at an honest price. Price per thirteen-ounce package, $25 \mathrm{c}$.; if by mail, I6c. extra for postage. Five-pound box (equal to six packages), $\$$ I, oo.

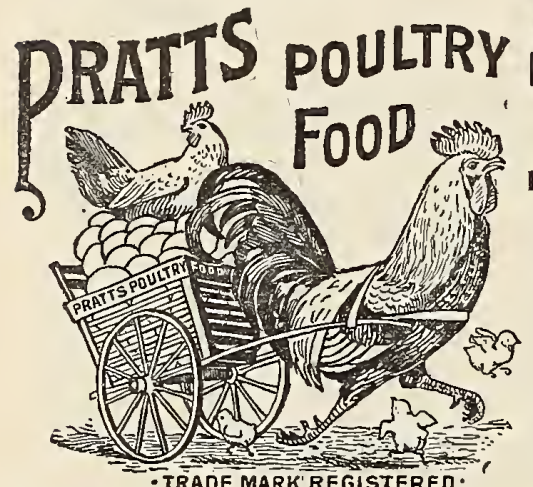

PRATTS POULTEY FOOD.

It is a sure cure for $\mathrm{Ch}$ icke $\mathrm{n}$ Cholera, roup, gapes, and all diseases of the flock. It regulates the bowels blood and digestive organs; it produces bone, muscle, feathers and

larger fowl.

It sells for $10 \mathrm{c}, 25 \mathrm{c}$. and 6oc. per package.

Roup Pills. They act directly on the glands and mucous membranes, a1lay all tendency to fever, promote healthy action of the liver, correct unhealthy conditions of the blood and stomach, restore appetite, and carry off all morbid matter from the system. They are entirely free from anything harmful, and are believed to be the best remeay ever discovered for roup, catarrh, colds, etc. Price $25 \mathrm{c}$. per box of fifty pills; $\$$ I.oo per box of two hundred and fifty pills.

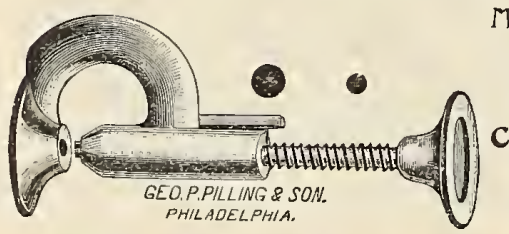

Marking Punch. For marking chicks or fowls. Price each, $25 \mathrm{c}$.

Caponizing Tools. Pilling's Sets with instructions.

Price each, $\$ 2.50$.

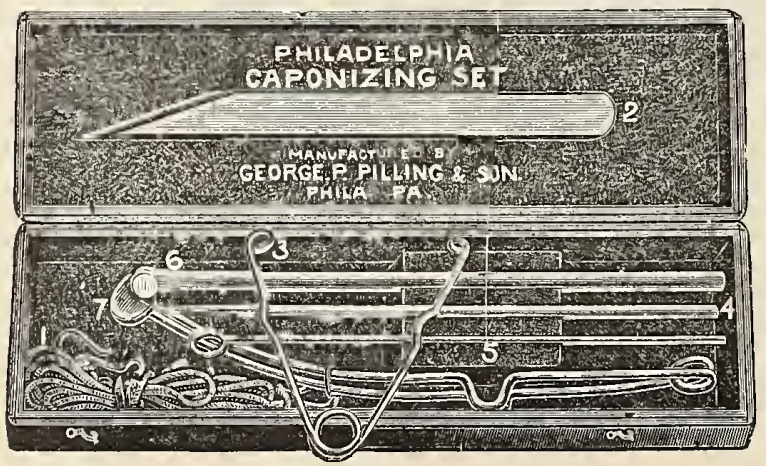

\section{NEST EGGS.}

China. Price each, 3c.; per dozen, 25c.; per gross, $\$ 2,00$.
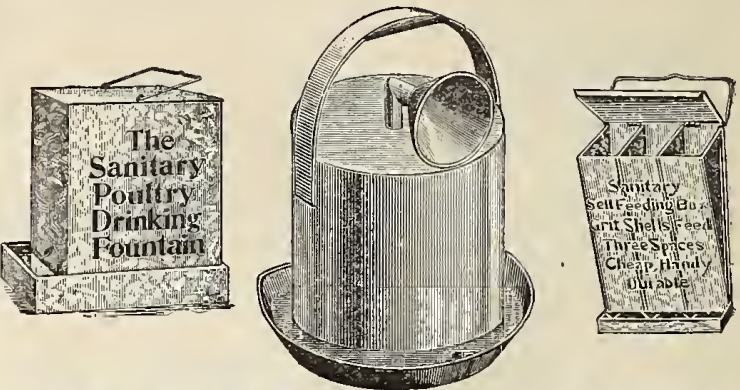

\section{BATES' SELF-FEEDING POULTRY, FOUNTAIN.}

Price, one gallon, $\$ \mathrm{I} .00$; three gallons, $\$ \mathrm{I} .50$.

\section{THE "SANITARY" POULTRY FOUNTAIN.}

This is made of galvanized iron, and is so designed that it can be easily opened and thoroughly cleaned, thus overcoming the objection to many other drinking fountains. Price, one gallon, 50c.; two gallons, $85 \mathrm{c}$.

\section{"SANITARY" SELF-FEEDING BOX.}

For grit, shells, bone, charcoal, feeds, etc. Made of heavy galvauized iron. Saves waste. Hangs on a nail. Neat, chea pand couvenient. Price, 5oc.

\section{DOG FOOD.}

Austin's Patent Dog Biscuit. Price per pound, 8c.; four pounds, $25 \mathrm{c}$; per one hundred pounds, $\$ 5 \cdot 50$.

Lederer's Patent Dog Biscuit. Per pound, 8c.; four pounds, 25c.; one hundred pounds, $\$ 5.50$.

\section{Squirrel Cages with Wheel.}

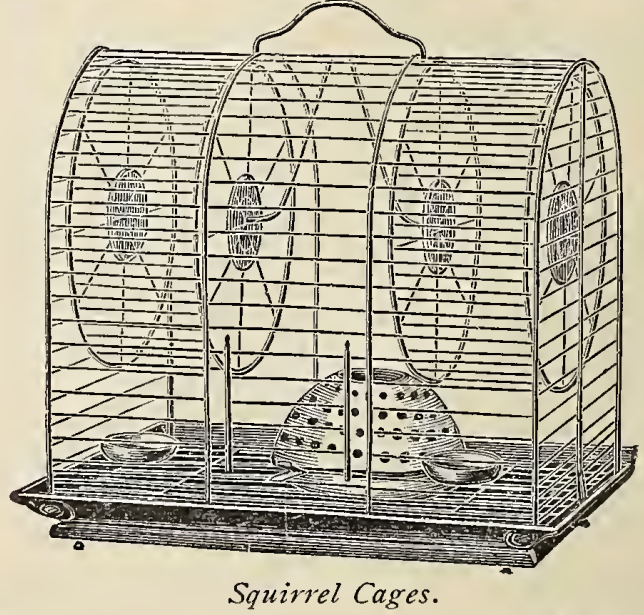

Chip.........................\$2.50 each. Red ............................ 3.00 each. Gray ........................... 4 . oo each. 


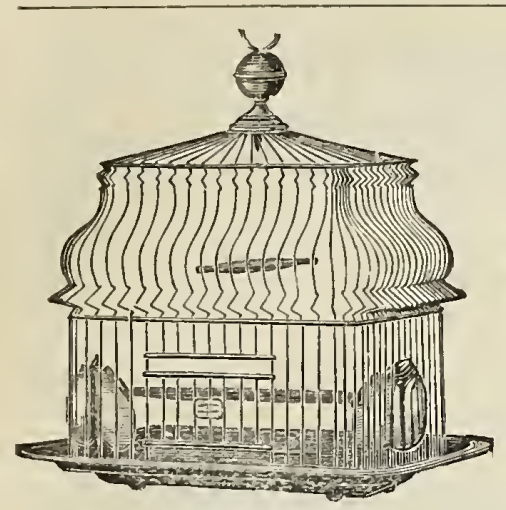

\section{carary BIRD cAGES.}

In brass, silver and japanned fiuish, and all the desirable shapes, at prices rangiug from 8o cents to $\$ 5.00$.

\section{PARROT \\ CAGES.}

Canary Cage.

All sizes. Prices from $\$ 1.25$ to $\$ 4.00$.

\section{Force Sprinkler and Rovelty Pump.}

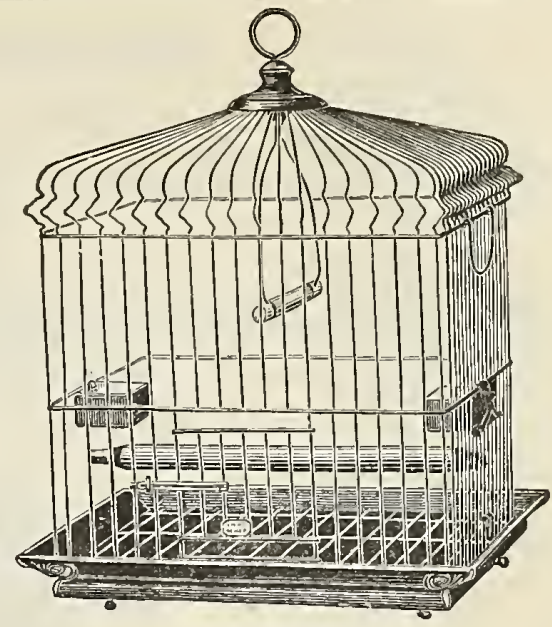

Parrot Cage.

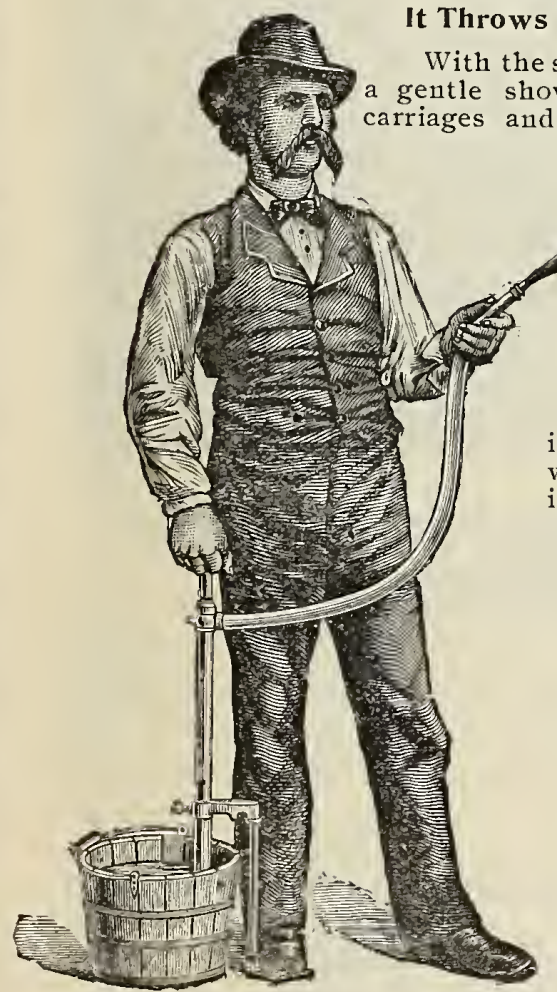

It Throws a Strong Stream Sixty Feet or More.

With the sprinkler attached it spreads the water in a gentle shower or spray For washing windows or carriages and showering lawns, gardens and greenhouses it has no equal. It is adapted to throwing liquid solutions of all kinds to destroy noxious insects and bugs of every nature on plant, vine and tree. Price, $\$ 5.00$.

\section{Fountain Pump.}

A most useful and convenient apparatus for watering shrubbery, gardens or conservatories; for washing windows, sidewalks, carriages, etc., and for extinguishing fires. Prices, $\$ 4.00$ and $\$ 4.50$.

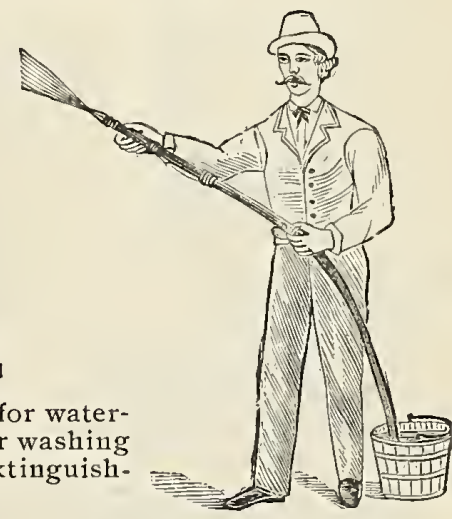

\section{The Aquapult Or Portable Hand Force Pump.}

A valuable article, which discharges a continuous stream. It will throw about eight gallons per minute. The various uses of this pump are obvious. It is recommended by agriculturists as the best spraying pump for Paris green and London purple. Price, $\$ 4.50$.

\section{Cyclone Spray Pump.}

Large Tank and double seamed heads. Tube stationary, so that there is no danger of getting out of place.

No. 1, All Tin. Price,

5oc.

No. 2, Tin Cylinder and Galvauized Irou Tavk. Price, $75 \mathrm{c}$.

No. 3, Tin Cylinder and Copper Tank. Price, \$I.co.

No. 4, All Copper. Price, $\$ 1.25$.

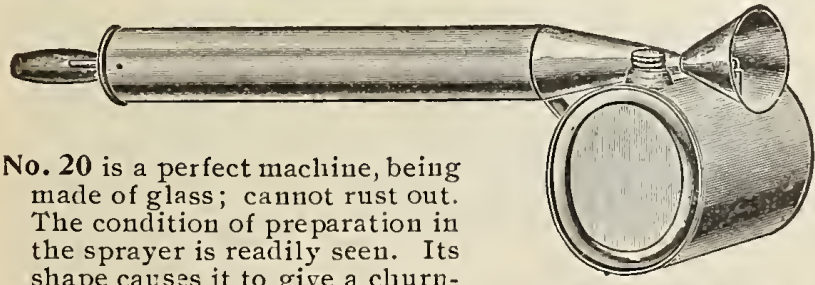

shape causes it to give a clurn-

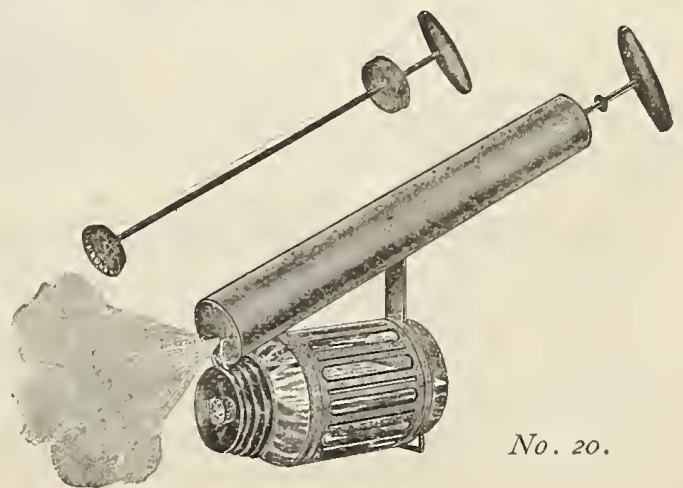

ing motion when in use, thus ke
thoroughly mixed. Price, $\$ 100$. 


\section{Improved Brass Syringes.}
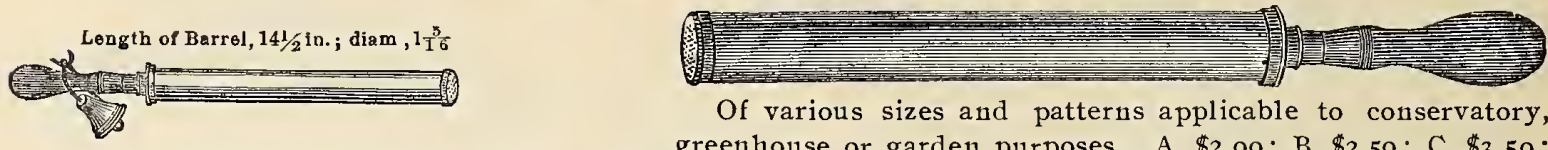

Of various sizes and patterns applicable to conservatory, A merlcan Improved syringe, 18 inches long; diameter, $11 / 2$.

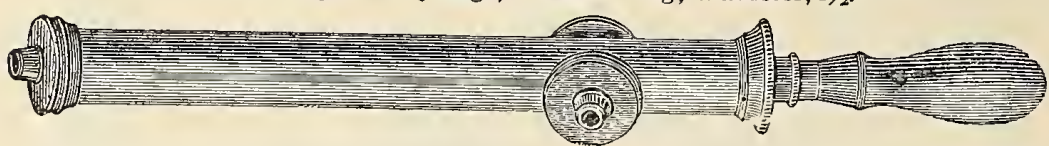
D, $\$ 4.50 ;$ No. $2, \$ 4.75 ;$ No. $3, \$ 6.75$; No. $5 . \$ 7.50 ;$ No. $7, \$ 10.00$.

Japanned Tin Syringes. Price, 75 cents each.
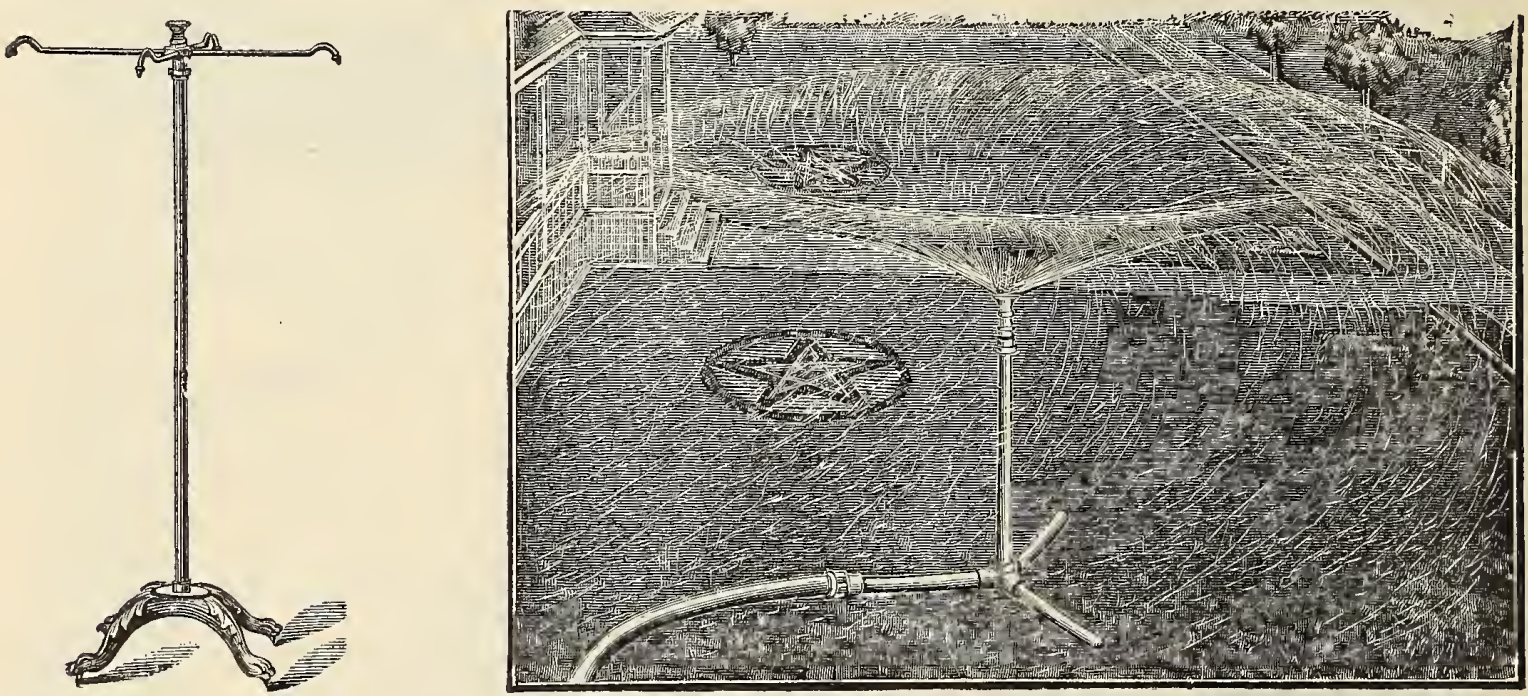

\section{Elastic Plant Sprinkler.}

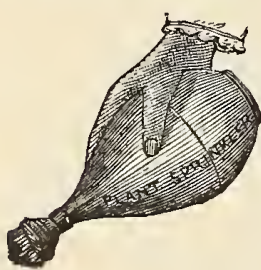

This article is made of rubber, with a flatbottom. The cap is of brass, finely perforated, which can be removed if desired. It is an indispensable article for showering the foliage of plants, sprinkling bouquets and dampening clothes. Three sizes. Price, 5oc., $75 \mathrm{c}$. and $85 \mathrm{c}$.

\section{Watering Pots.}

\section{Heavy Tin Watering Pots Painted} Green.

One quart, I $_{5}$ c.; four quarts, $25 \mathrm{c}$; six quarts, $30 c$; eight quarts, $40 c$. ten quarts, 5oc.; twelve quarts, 6oc.; sixteen quarts, $75 \mathrm{c}$.

\section{The Water Vilitch Lawn Sprinkler:}

The waterflow is unimpeded, scattering in fine drops evenly over a circular area twenty-five to forty feet diameter. Price, without stand (i.e., with spur to stick in the ground), 50c. each; by mail, 6oc. Price with stand, \$1.0o each.

\section{Nickel-Plated Lawn Spirinkler.}

The price at which these sprinklers are offered enables everybody having a sufficient head of water to have a beautiful fountaiu on the lawn, which not only pleases the sight but is beneficial to the grass. Every sprinkler warranted. Regular four arms, with ball top, price, \$3.oo. Regular eight arms, with ball top, price, $\$ 4$.oo.

\section{The Standard Powder Gun.}

Almost any dry powder may be used, such as Paris Green, Fungiroid, Spanish Pink, London Purple, Sulphur, etc. Price each, $\$ 5.00$.

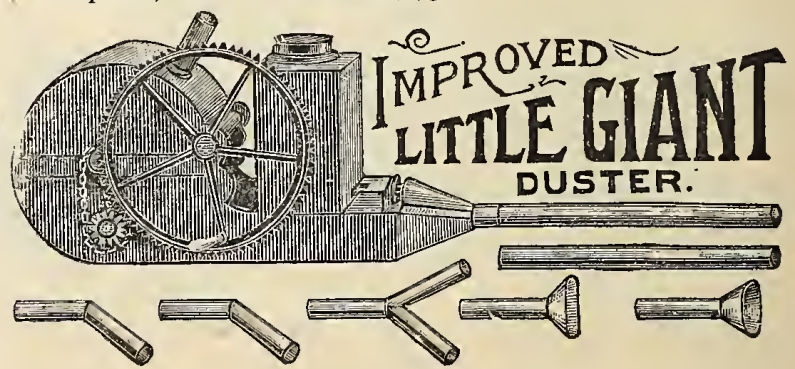




\section{The Champion or Dry Powder Gun.}

It will distribute insecticides in a dry or powdered state, effectively and satisfactorily. Price each, $\$ 7.50^{\circ}$.
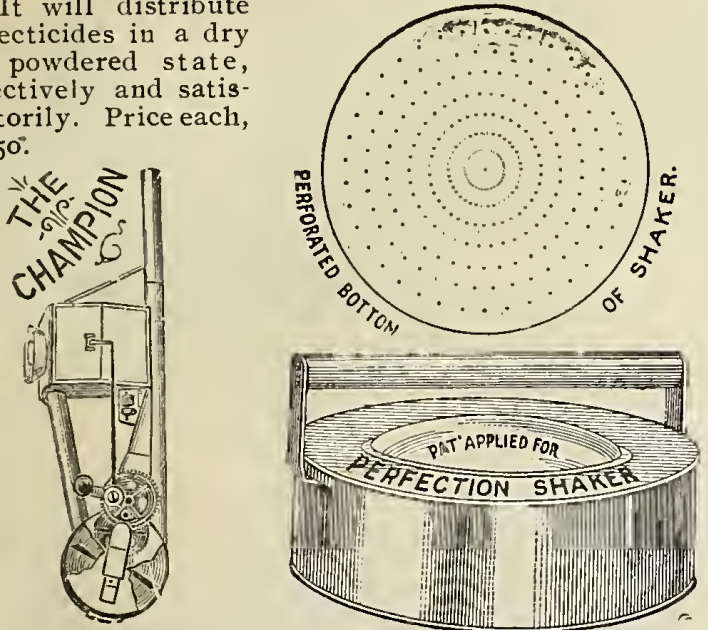

\section{Perfection Shaker.}

Especially for applying Bug Death to potato vines. Price each, 65 cents.
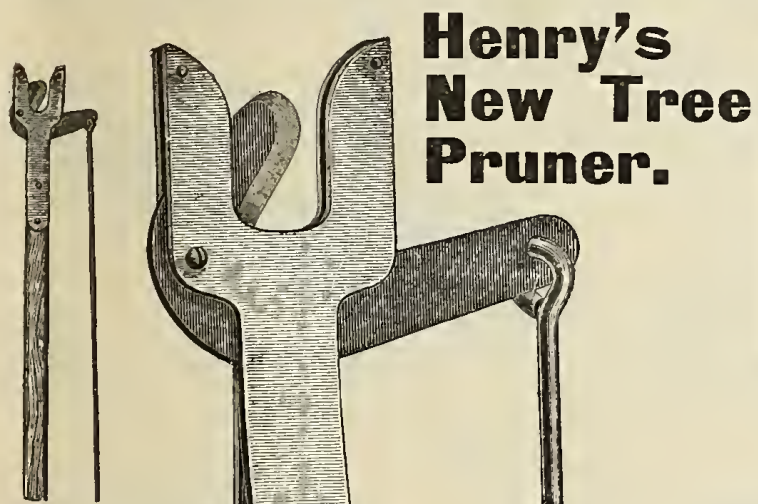

Henry's

\section{Pruning} Shears.

These shears have an extensive sale among wool growers for trimming sheep's feet, and are largely used among orange growers for pruning orange trees. Handle, malleable iron. Blades best cast steel. Price each, $50 \mathrm{c}$.
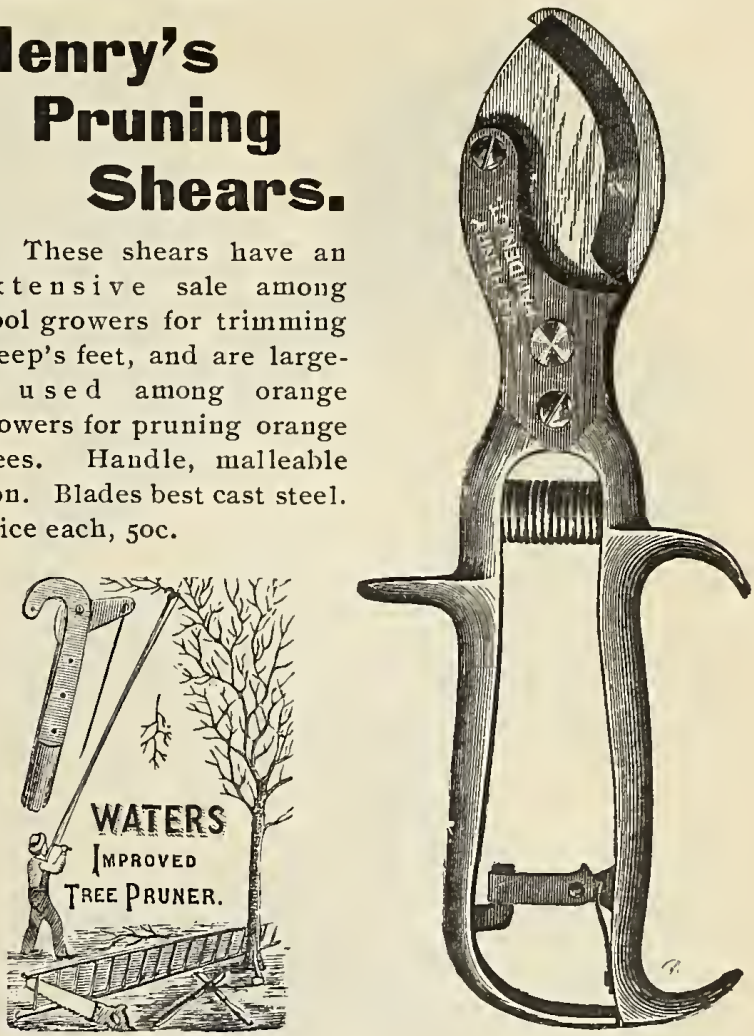

\section{Water's Improved Tree Pruner.}

The small space required for working the knife allows it to be used among close, dense branches, where great difficulty is found in using the old-fashioned shears.

For pruning raspberry, blackberry and rose bushes it has proven peculiarly serviceable.

For removing worms' nests and thinning out fruits it is very desirable, and can be used as a fruit picker. Length of pole, $4 \mathrm{ft}$.; weight, $2 \mathrm{I} / 2$ lbs.; price each, $\$ \cdot 75$

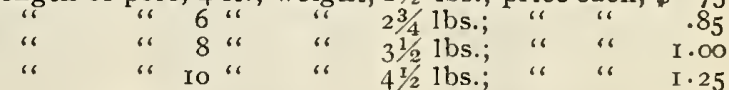

Extra knives, per doz., $\$ 3.50$; each, $25 \mathrm{c}$.

\section{Glass Gutting and Glaz= ing Tools.}

Workmen who use this instrument find it cuts glass as rapidly as a glazier's diamond, and for all the purposes of cutting and setting glass is just about equally valuable, though it costs not one twentieth as much. A tool which contains the appliances for cutting and setting glass has also attached to it a steel for sharpening knives and scissors, and also a corkscrew. Price each, roc.; per doz., \$I.oo. 


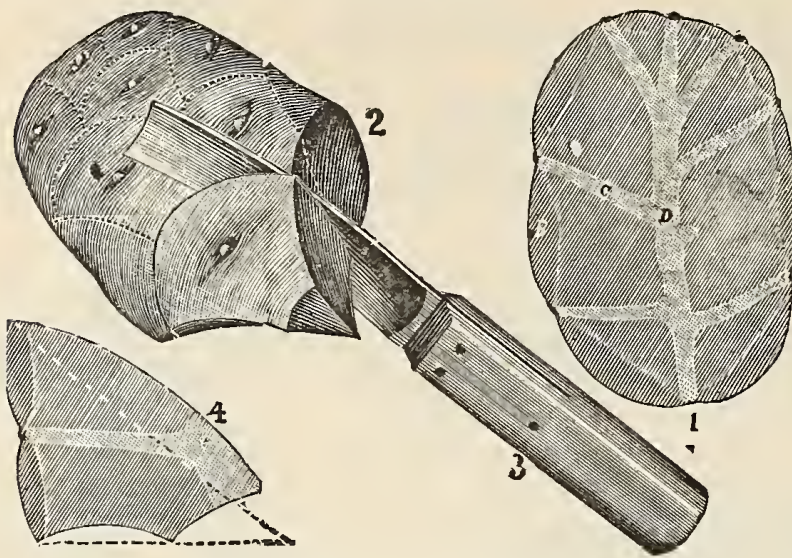

Humphrey's Concaved and Curved Potato Knife.

\section{Humphrey's Concaved and Curved Potato Knife.}

This knife will cut two or three eyes in a piece. One eye will be as good or better than half a potato cut in any other way. The potato can be cut easier, faster and better. If you cut no more than one bushel of potatoes, it will pay to cut them with the concaved and curved seed potato knife. Illustrated circular, showing structure and full directions for cutting, with each kuife, Price, 25c.

\section{Lightning Sack and Bag Holder.}

The bag is attached a nd detached as quick as lightning. Hence, the name. Don't think because it's cheap it is not good. If you don't consider it as good as any bag holder you ever saw,

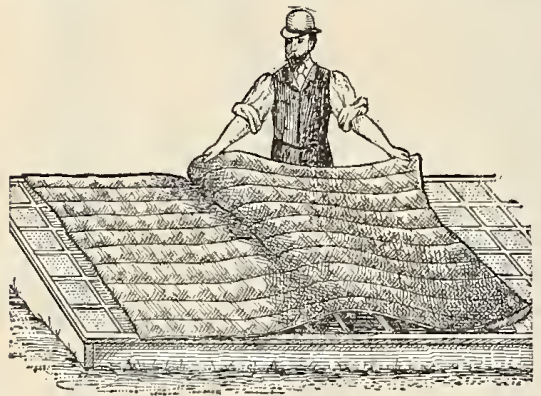
and far more couvenient, send it right back and get your money. After you get one you will want another or several. You will find several around the farm as convenient and desirable as several pockets in your every-day suit of clothes.

Remember, only 25 Cents for the Best Bag Holder on Earth.

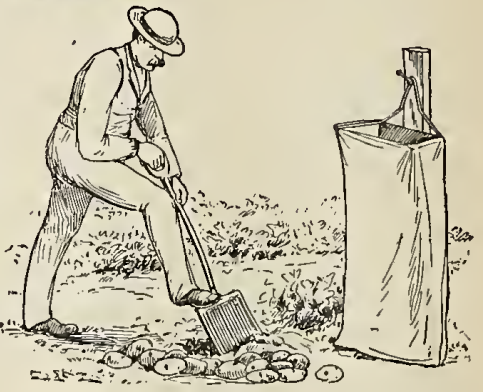

Lightning Sack and Bag Holder.

\section{Burlap Hot Bed Mats.}

Heavy burlap exterior with wool filling, securely quilted and bound. An excellent winter covering for hot-beds, cold frames, in fact anything requiring a heavy mat covering for winter protection. $76 \times 76$ inches, $\$ 1$.oo each.

\section{Border Kmïe and Weeding Hoe.}

For edging up walks and borders. Expressly adapted for cutting turf, cleauing walks from weeds, working in gardens, around shrubbery and flower beds, the combination permitting instant change from edger to shuffle hoe. Price, seven-and-one-half inch each,5oc.; nine-inch, $65 \mathrm{c}$. each.
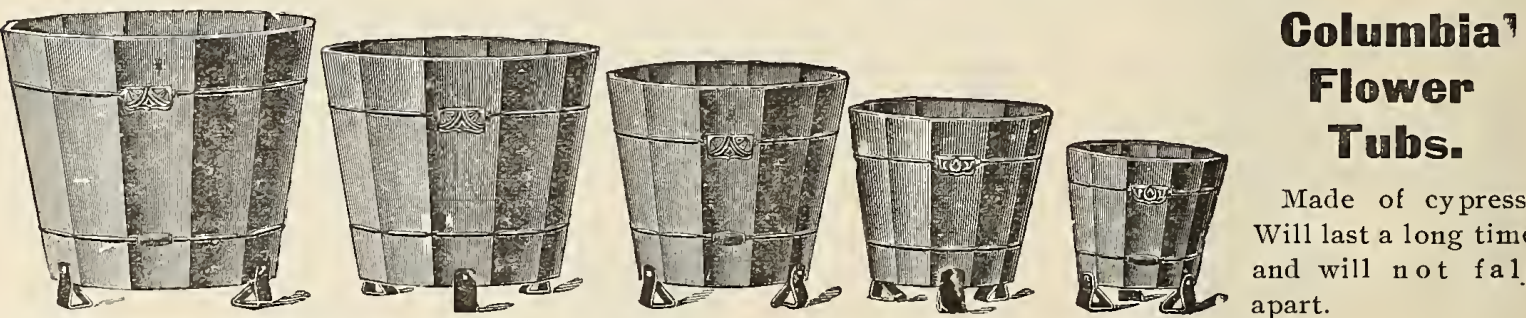

Made of cypress. Will last a long time and will not fall apart.

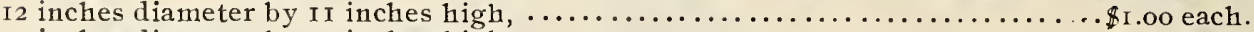

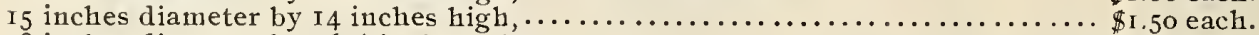

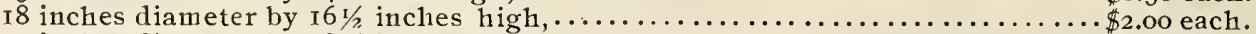

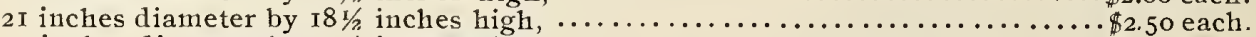

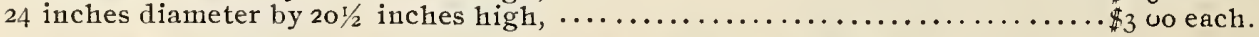

\section{Van Reyper's Perfect Glaziers' Points.}

Endorsed by leading florists. Try them and you will use no other. Made of steel wire and galvanized; no rights and lefts; over 8,000,000 in use. Made in four sizes-Nos. I, 2, 3, 4. Price per box of $\mathrm{I}, 000,65 \mathrm{c}$; in lots of 5,000 by express, $55 \mathrm{c}$. per $\mathrm{I}, 000$; pincers for driving the points, $40 c$; by mail, $50 c$.

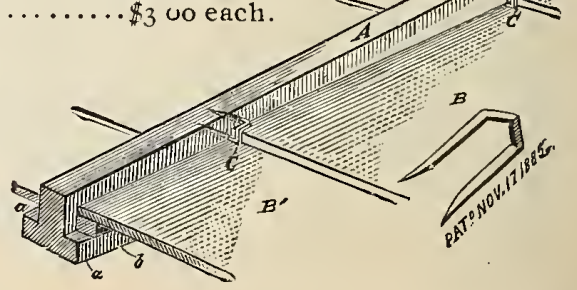



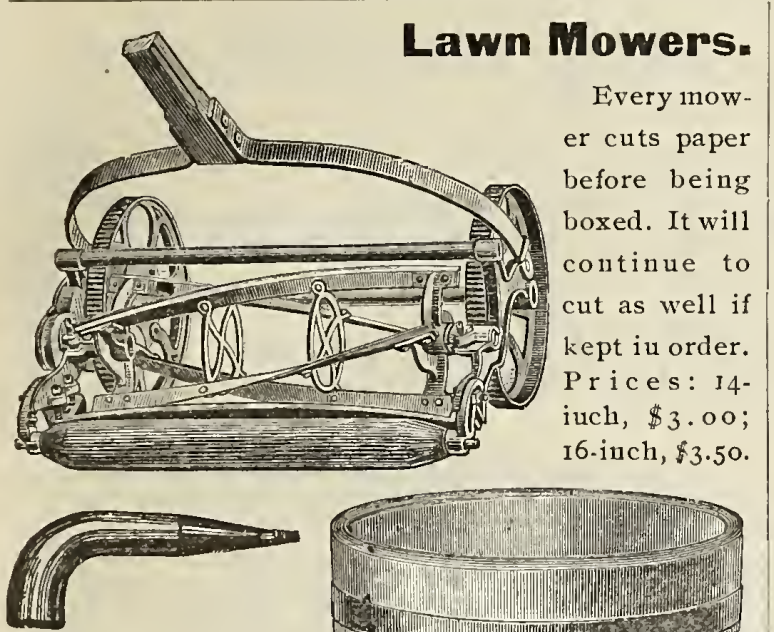

Dibber.

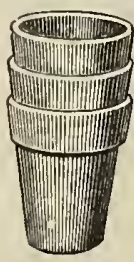

Flower Pots.

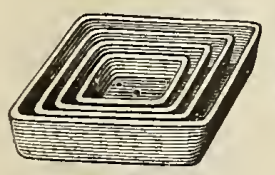

Seed Pans.

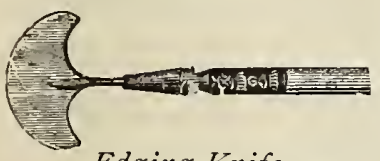

Edging Knife.

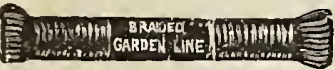

Garden Line.

Floral Tools (in sets).

Excelsior Weeding Hooks.

Garden Trowels.

Border Forks.

Shuffle Hoes.

Garden Lines.

Garden Reels.

Dahlia Poles and Flower Sticks.

Pot, Plant and Flower Trellises.

Faucy Flower Pots.

Hanging Flower Pots.

Crocus Pots.

Window Boxes.

Commou Flower Pots.

Grass Hooks.

Paris Green Dusters.

Sulphur Bellows.

Plant and Tree Labels.
Every mower cuts paper before being boxed. It will continue to cut as well if kept iu order. Prices: 14 iuch, $\$ 3.00$; I6-inch, $\$ 3.50$.

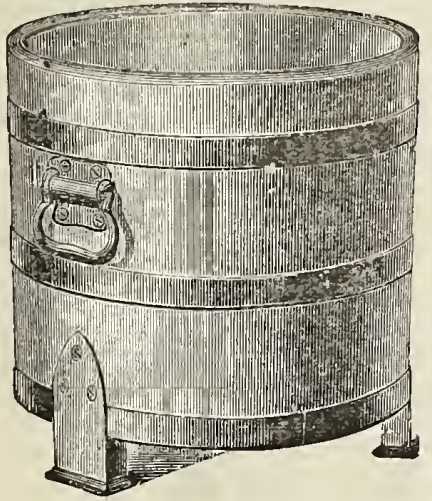

Tree $7 u b$.

Wire Flower Stands. Seed Pans.

Stenming Wire.

Wire Forms.

Tiu Foil.

\section{Broadcast Hand Seed Sowers.}

This machine runs so easily and smoothly that the weight of the haudle will run the machiue. Equipped with agitator and accurate seed gauge.

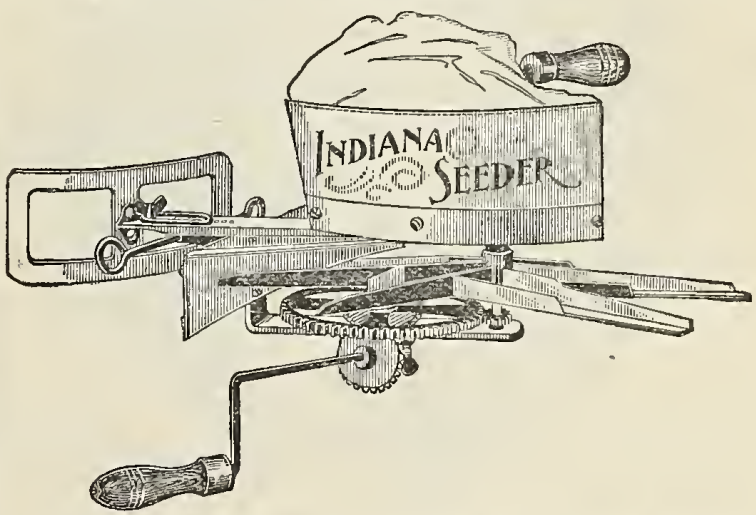

It will sow Wheat, Rye, Oats, Rice, Flax, Millet, Turnip Seed, Clover Seed, Grass Seed, including

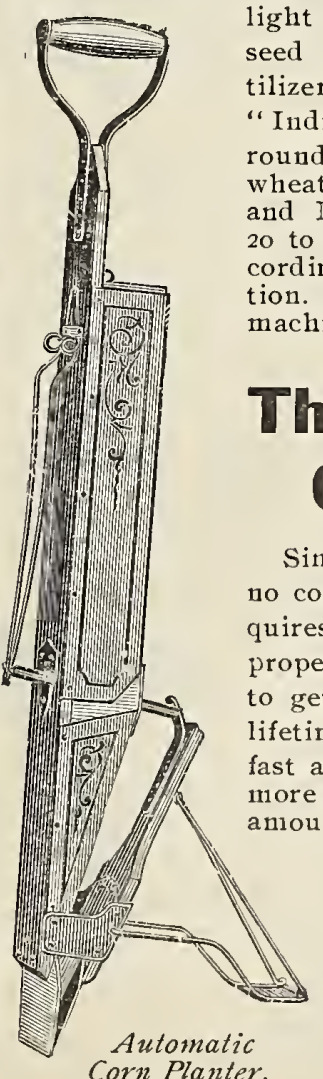
light grasses, in fact any kiud of seed broadcast. Also Plaster Fertilizer, Salt, Ashes, etc. The "Indiana Seeder" will sow at a round, Wheat or Rye, 50 feet; Buckwheat, 45 feel; Flax Seed, Clover and Millet, 36 feet; Grass Seeds20 to 36 feet; other seeds, etc., according to their nature and condiion. Full directions sent witl each machine. Price, $\$ 1.50$.

\section{The Automatic Gom Planter.}

Edging Knives.

Grafting, Pruning and Budding Knives.

Pruning Shears.

Round and Square Ferneries.

Fernery Globes.

Hyacinth Glasses.

Flower Pot Covers.

Flower Pot Brackets.

Flower Pot Shelves with Swinging Brackets.

Wood Flower Stands.

Hanging Basket Hooks.

Bird Cage Hooks.

Hedge Shears.

Box Shears.

Pruning Hooks.

Rustic Work.

Hanging Baskets.
Simple, durable, economical; has no complicated machinery, and requires no special skill to use it with proper satisfaction. It is not liable to get out of order, aud will last a lifetime. Plants with one hand as fast as a man can walk, and with more precision as to depth and amount of seed than can he done iu the old way. The old laborious system of planting corn and beans is changed to a pastime, and more than threefourths the expense saved by this simple but ingenious contrivance. Price, Corn Planter. $\$ 1.75$. 


\section{THE EUREKA}

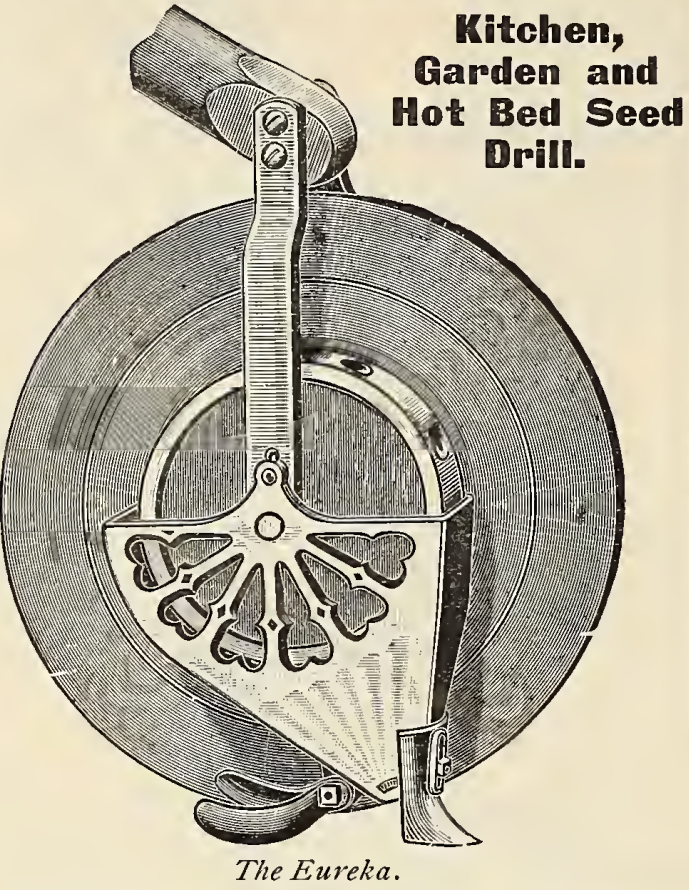

It will sow and cover Beets, Cabbages, Carrots, Celery, Lettuce, Onions, Radishes, Spinach, Turnips, and all such seeds, with the greatest regularity. The quality of work equals that done with the costly machines and infinitely better and faster than hand work. Price, \$I.oo.

\section{Daisy Hand Weeder.}

It is especially adapted to thinning out plants and weeding among all vegetables or flower plants, doing the work better, easier and quicker than by ordinary methods. Price each, 25c.; per doz., $\$ 2.50$.

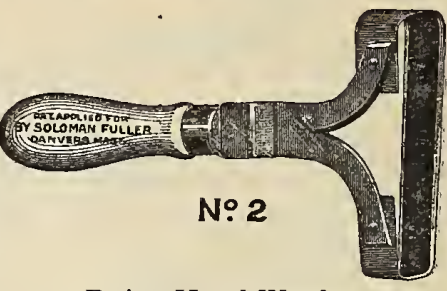

Daisy Hand Weeder.

\section{Lang's Hand Weeder.}

This is not only a good weeder and scraper, but with its point becomes a good implement for the thinning ou t where plants are too thick and for lightening the soil. The blade

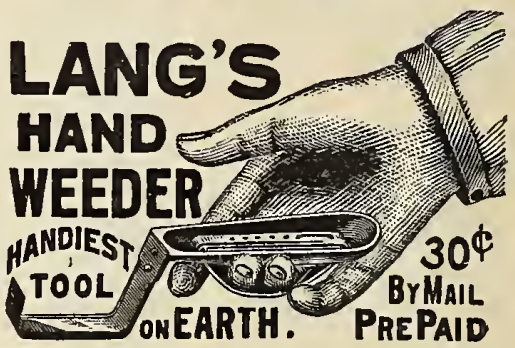
is solid steel, and is sharp on all its edges. Capital for weeding, thinning and stirring soil among onions, carrots, strawberries, etc. Price each, per express, 25c.; per mail, post paid, 3oc.

\section{Excelsior Weeding Hook.}

This implement can be used to great advantage among small and tender plants. Price each, I5c.

YOU .VEEDN'T BREAK YOUR BACK WITH A

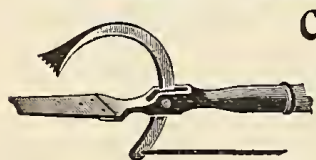
CLEVELAND LAWN WEEDER.
This little device gets at the root of the evil and re= moves it bodily. The curved edge of the blade enters and loosens the soil; pressure on the lever then causes the toothed jaw to grasp the plant,

and a slight pull suffices to dislodge same without disturbing the surrounding sod. Price, 5oc.

\section{Diamond Hand Weeder.}

This is a convenient, cheap and useful little implement for clearing away weeds, working between plants, dressing pots, and for other small work where a large hoe could not be easily used. Price each, Ioc.; per dozen, \$1.oo.

\section{Trowel.}

Cleve's Angle Trowel. A'weed digger, transplanter and cultivator. This handy digger was originally intended for digging weeds from

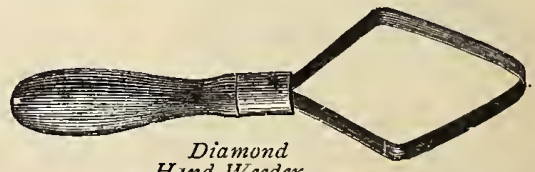
Diamond

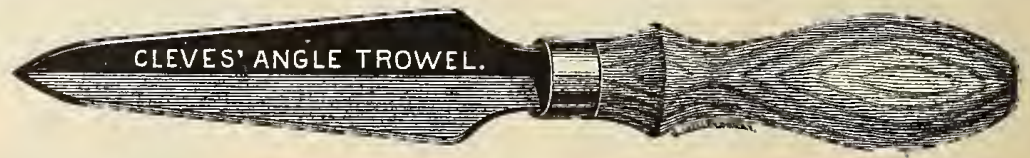

the lawn, but has found great favor among florists and amateurs for transplanting seedlings and stirring. the soil. Price each, I5c., 20c. and $25 \mathrm{c}$.

Common Garden Trowel. Price each, five-inch, Ioc.; six-inch, I2c.; seven-inch, I5c.

\section{Tying Materials.}

Cuba Bass. Price per pound, 2oc.

Jute Tying Twine. Price per pound, i5c.

Raphia. Price per pound, 2oc.

\section{Thermometers.}

Japanned Tin Cases. Seven-inch, Ioc.; eight-inch, I2c.; ten-inch, I5c.; twelve-inch, $25 \mathrm{c}$.

\section{Trowbridge's Grafting Wax.}

In one-pound, one-half-pound, one-quarter-pound packages. Price per one-quarter pound, Ioc.; per onehalf pound, I5c.; per pound, $25 \mathrm{c}$.

\section{Tree Labels.}

Notched and Copper Wired. Price per one hundred, 2oc.; per one thousand, $\$ 1.80$. 


\section{Garden and Pot Labels, Painted.}

Four and one-half inch. Price per dozen, 5c.; per ove-hundred, 20c.; per one thousand, $\$$ I.0o.

Six inch. Price per dozen, 6 c.; per one hundred, 25c.; per one thousand, $\$$ I.25.

Eight inch. Price per dozell, Ioc.; per one huudred, $50 c$.

Twelve inch. Price per dozen, 2oc.; per one hundred, $90 c$.

\section{Gedar Bean Poles.}

Good quality, straight and sharpened. Price per dozen, 5oc.; per one hundred, $\$ 3.50$.

Best quality, eight to teu feet, large and straight, sharpened. Price per dozen, 75c.; per one hundred, $\$ 5.00$.

\section{Self-Closing Tomato Vine Support.}

Here is a very convenient article. It is a well-knowu fact that toniatoes lose much of their flavor by lying on the ground, and the cost of sup. ports will be paid for in one season by the improved quality of the fruit. Price each, I 5 c.; per dozen, $\$ 1.50$.

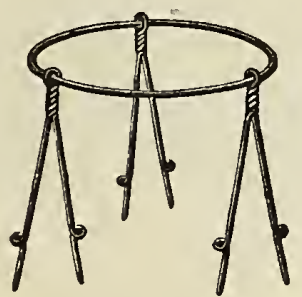

READY F OR USE

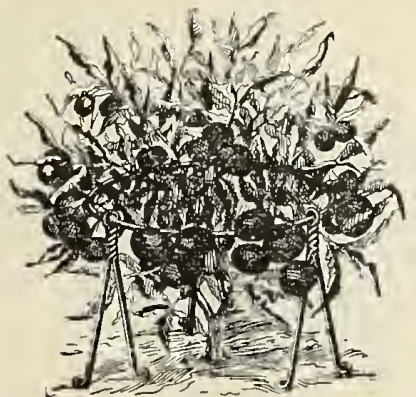

IN USE

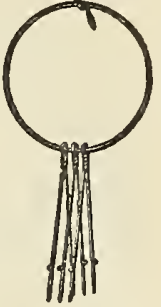

NDT IN USE

\section{Light, for Frail Plants. Plant Stakes. Heavy, or Dahlia Stakes.}

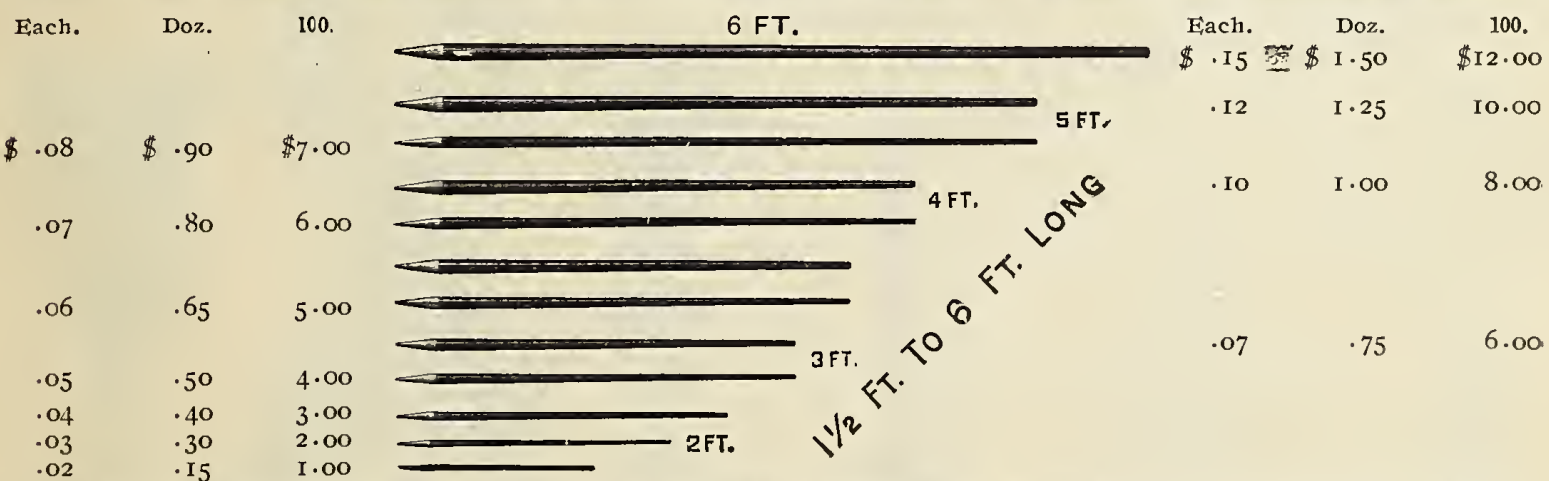

Made for supporting frail plants, such as fuchsias, carnations, tuberoses, etc. They are round, taper to. the top, aud are painted green.

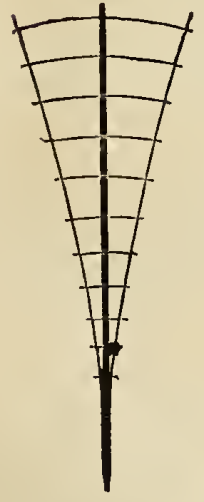

Flower and

Vine Trellis.

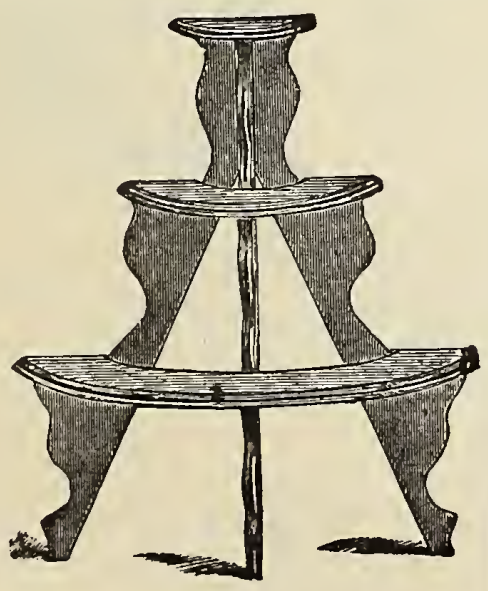

Flower Stand.

ROLLING STANDS.

The Fibre $=$ Ware Saucer shown by the accompanying illustration permits of the moving of heavy potted plants

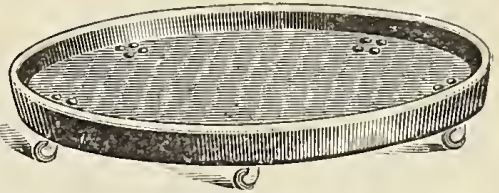
palms, etc., without labor or difficulty. It is entirely free from joints, and consequently perfectly watertight; is not affected by moisture ; cannot rust ; is light, strong and durable. Its ball-bearing castors, with hard-wood rollers, run easily, and raise the saucer sufficiently high to permit of a free circulation of air beneath.

Outside diam. Will take pot. Castors. Price each.

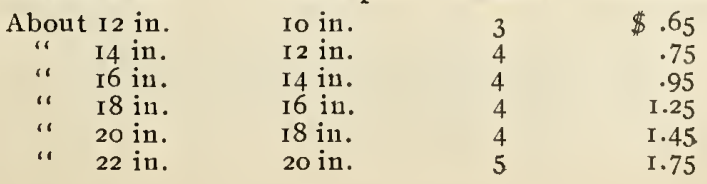




\section{Flower and Vine} Trellises.

Froni sixteen inches to twelve feet high. Made up in good, substantial manner, neatly painted, and suitable for pot, garden and veranda trellises.

\section{Flower Stands.}

Of wood, with three or four shelves. Price each, $\$ 1.25$ to $\$$ r.5o.

\section{Rustic Hamging Baskets.}

Ten inch, price each, 85c.; eleven inch, \$I.OO; twelve inch, \$r.25.

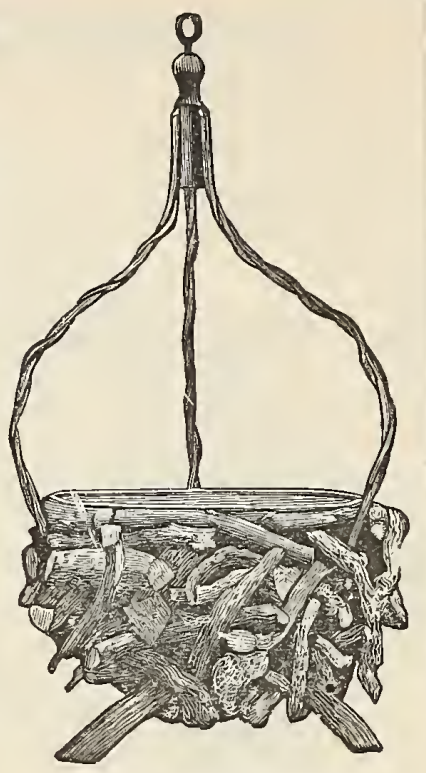

Rustic Hanging Basket.

\section{The New Mlodel Pole Trap.}

This trap is made of all malleable iron and steel; it has eight needles in the pin plate. It is light, neat, durable and attractive. Price each, $\$$ I.5O.

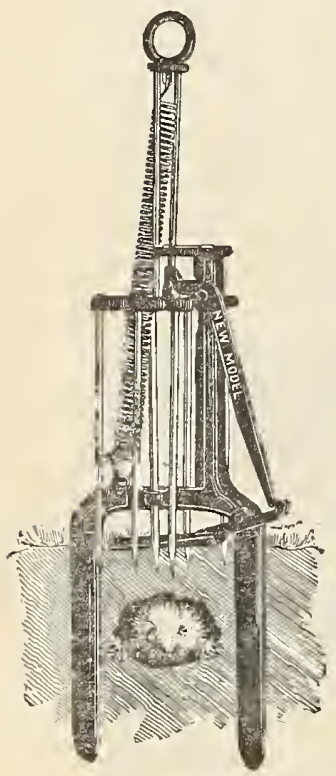

New Model.

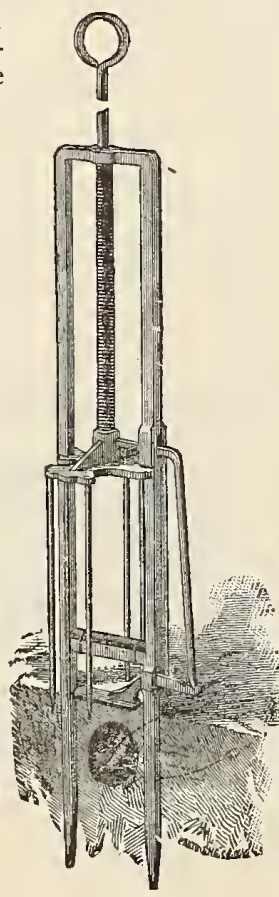

Reddick.

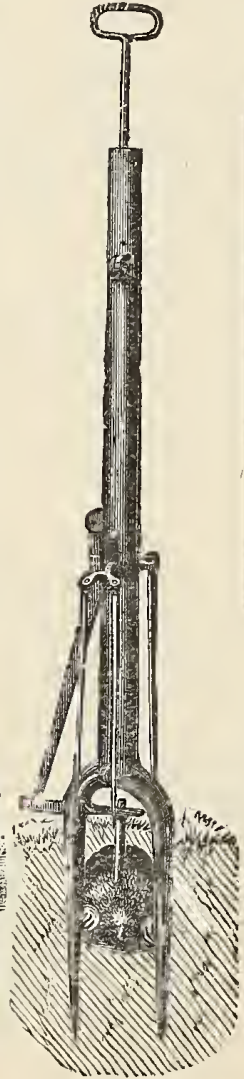

Isbell.

\section{The Reddick Mole Trap.}

This is a $\$$ I.oo trap. practical and effectual; galvanized throughout to prevent rust.

\section{Isbell Mole Trap.} $\$$ I.75.

\section{"Out o" Sight" Mole Trap.}

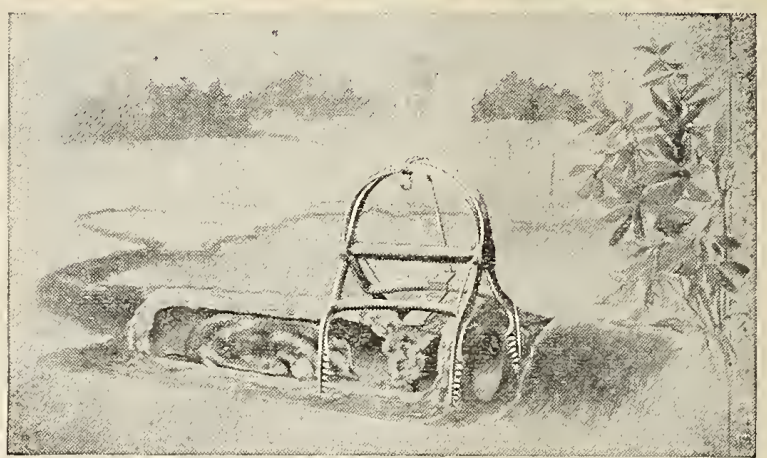

This cut shows the "Out of Sight," and has only to be tried to be appreciated. The secret of mole catching is a good trap and to know their habits. Full information sent with eacli trap. Price each, $75 \mathrm{c}$.
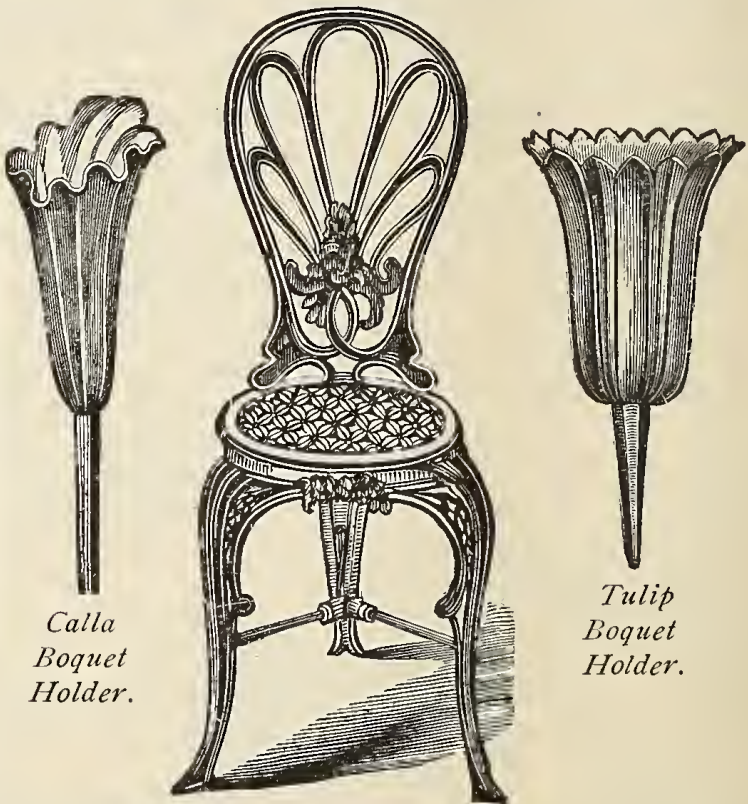

Calla

Boquet

Holder.

Iron Chair- $\$ 4.50$.

\section{Calla Boquet Holder.}

Green. Prices-No. o, 25c.; No. I, 35c.

Galvanized. Prices-No. o, 35c.; No. I, $50 \mathrm{c}$

\section{Tulip Boquet Holder.}

Green. Prices-No. 4, $20 \mathrm{c}$; No $5,25 \mathrm{c}$; No 6, 3oc.

Galvanized. Prices-No. 4 , 25c.; No. 5 , 35c.; No. 6, $40 \mathrm{c}$.

\section{Tulip \\ Boquet \\ Holder.}

FRANK S. PiATT,

January I8th, I9or.

New Haven, Conn.:

Dear Sir:-I have bought my seeds of you for many years. Well suited.

C. P. JORDAN,

West Haven, Conn. 
Showing the number of pounds per bushel, quantity usually sown per acre.

Barley, broadlcast.

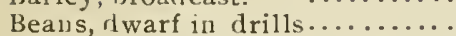

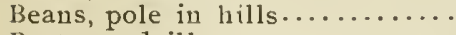

Beets, in drills..................

Beets, in drills, Mangel Wurtzel.

Broom Corn, in hills...........

Buckwheat.................

Cabbage, in beds to trausplant..

Carrot, in drills.... ..........

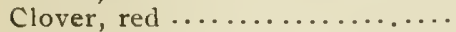

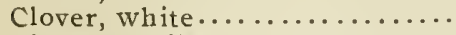

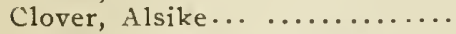

Clover, Lucerne or Alfalfa .....

Corn, in hills................

Corn, for soiling.............

Cucumber, in hills............

Flax, broadcast..............

Grass, Kentucky Blue.........

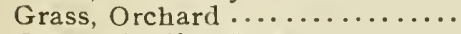

Grass, English Rye...........

Grass, Sweet Vernal ...........

Grass, Red Top..............

Grass, Rhode Island Bent......

Grass, Timothy or Herd's Grass.

Grass, Hungarian............

Grass, Mixed Lawn...........

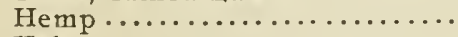

Kale.

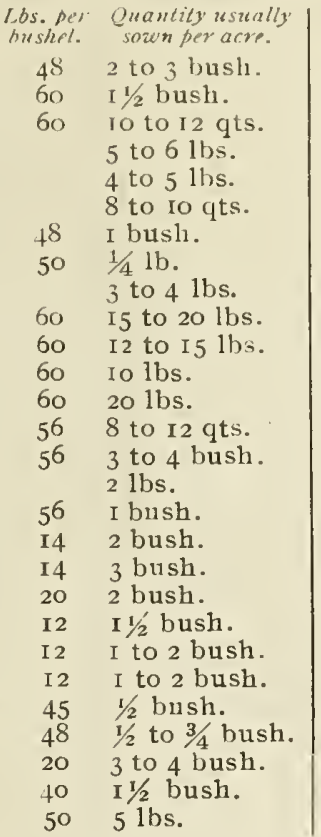

\begin{tabular}{|c|c|c|}
\hline & $\begin{array}{l}\text { Lbs.per } \\
\text { bushel. }\end{array}$ & $\begin{array}{l}\text { Quantity usuall. } \\
\text { sown per acre. }\end{array}$ \\
\hline Mustard, broadcast............ & 50 & $1 / 2$ bush. \\
\hline Melon, Musk, in hills......... & & 2 to 3 lbs. \\
\hline Melon, Water, in hills......... & & 3 to 4 lbs. \\
\hline Millet, broadcast............. & 48 & $1 / 2$ to $3 / 4$ busls. \\
\hline 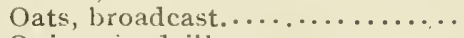 & 32 & $2 \frac{1}{2}$ to 3 bush. \\
\hline 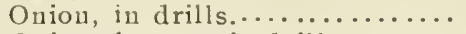 & & 5 to 6 lbs. \\
\hline Onion, for sets, in drills ........ & & 30 lbs. \\
\hline 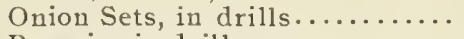 & & 8 to 12 bush. \\
\hline 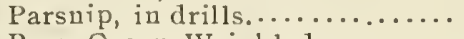 & & 4 to 6 lbs. \\
\hline Peas, Green Wrinkled..... & $5^{6}$ & $1 / 4$ to $1 / 2$ bush. \\
\hline Peas, Round Hard, in drills.... & 60 & I $1 / 2$ bush. \\
\hline$\ldots \ldots \ldots \ldots$ & 60 & 3 bus \\
\hline bers........... & 60 & 6 to Io bush. \\
\hline $\begin{array}{l}11 \mathrm{~s}, \ldots \ldots \ldots \ldots \\
\mathrm{s} \cdot \ldots \ldots \ldots \ldots\end{array}$ & & $6 \mathrm{lbs}$ \\
\hline aye, broadcast, Fall... & 56 & $\begin{array}{l}8 \text { to } 10 \text { lbs. } \\
\text { I } 1 / 2^{1} \text { to } 2 \text { bush. }\end{array}$ \\
\hline 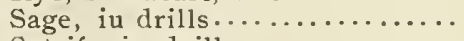 & & 6 to \\
\hline$y$, in drills & & 8 to \\
\hline$\cdots$ & & \\
\hline$\cdots$ & $=$ & 2 \\
\hline$\cdots \cdots \cdots \cdots$ & & \\
\hline ieties, ) in hills & & \\
\hline ng varieties,) " & & 3 to \\
\hline olant............ & & I \\
\hline${ }^{\prime a}$. & & $11 \%$ to \\
\hline dcast $\ldots \ldots \ldots \ldots$ & & $\frac{1}{3 / 2}$ \\
\hline Theat, broadcast, & & \\
\hline
\end{tabular}

The Number of Plants, Trees, etc., Required to Set an Acre.

\begin{tabular}{|c|c|c|}
\hline Number. & Distance. $\quad$ Number. & Number. \\
\hline$\cdots$ & 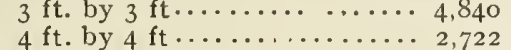 & $\begin{array}{llll}\ldots & \ldots & \ldots & \text { I94 } \\
\ldots & \ldots & \ldots & \text { I } 34\end{array}$ \\
\hline 90 & $\ldots \ldots \ldots . \quad 1,742$ & $\ldots \ldots \ldots$ I05 \\
\hline 70 & $\cdots . .1,2$ IO & $\cdots \ldots \ldots$ \\
\hline$\cdot \mathbf{I}$ & $\cdots \cdots$ & $30 \mathrm{ft} \ldots \ldots \ldots \ldots \ldots$ \\
\hline - & $\mathrm{y}$ I $2 \mathrm{ft} \ldots \ldots \ldots \ldots \ldots$ & $40 \mathrm{ft} \ldots \ldots \ldots \ldots$ \\
\hline
\end{tabular}

JANUARY 10, I90I.

Frank S. PlatT, New Haven, Conn.

Dear Sir-Shall be pleased to have your catalogue. Can testify to value received for all grass seeds bought of you in the past two seasons, and will gladly recommend your house to my friends.

D. C. PECK, Newtown, Conn.

JANUARY I8, I9OI.

Frank S. Plati, New Haven, Conn.

Dear Sir-Have bought seeds of you for many years.

\section{P. A LINDQUIST, Stony Creek, Conn.}

JANUARY 2I, IgOI.

Frank S. Plate, New Haven, Conn.

Dear Sir-The seeds I have bought of you lieretofore, have been very satisfactory.

$$
\text { H. H. MILLER, Meriden, Conn. }
$$

\section{JANUARY 24, I9OI.}

Frank S. Platit, New Haven, Conn.

Dear Sir-Having bought seeds of you which roved satisfactory, I gladly send you names of two thbors who use seeds.

E. C. WARNER, Station A, City.
Frank S. Platt, New Haven, Conn.

Dear Sir-Your seeds have always been satisfactory. MRS. G. L. MINER and L. R. MINER, Cornwa!l, Coun.

Frank S. Platt, New Haven, Coun.

Dear Sir-Seeds all O. K.

D. C. MUNSON, No. Ioz Central Ave., City.

JANUARY I8, I9OI.

Frank S. Plati, New Haven, Conn.

Dear Sir-I have used your seeds for many years and they have always been satisfactory. G C. JENSEN, Middletown, Coun.

JANUARV 21, 19OI.

Frank S. Plate, New Haven, Conu.

Dear Sir-We had your seeds last year aud consider them excellent.

ANDREW PALMER,

West Torrington, Conn.

JANUARY 20, 1901 .

Frank S. Plat'T, New Haven, Conn.

Dear-Sir-Your seeds have always proved to be first-class. HENRY A. ENGELHARDT, Collinsville, Coun. 
